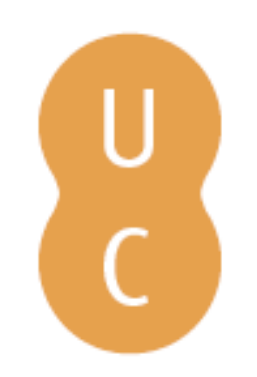

\title{
pompalina
}

\section{Sons do Clássico: no 100aiversário de Maria Augusta Barbosa}

Autor(es): $\quad$ Miranda, Margarida Lopes de, ed. lit; Cardoso, J. M. Pedrosa, ed. lit.

Publicado por: Imprensa da Universidade de Coimbra

URL

persistente: URI:http://hdl.handle.net/10316.2/11952

DOI: $\quad$ DOI:http://dx.doi.org/10.14195/978-989-26-0567-8

Accessed : $\quad$ 26-Apr-2023 11:09:16

A navegação consulta e descarregamento dos títulos inseridos nas Bibliotecas Digitais UC Digitalis, UC Pombalina e UC Impactum, pressupõem a aceitação plena e sem reservas dos Termos e Condições de Uso destas Bibliotecas Digitais, disponíveis em https://digitalis.uc.pt/pt-pt/termos.

Conforme exposto nos referidos Termos e Condições de Uso, o descarregamento de títulos de acesso restrito requer uma licença válida de autorização devendo o utilizador aceder ao(s) documento(s) a partir de um endereço de IP da instituição detentora da supramencionada licença.

Ao utilizador é apenas permitido o descarregamento para uso pessoal, pelo que o emprego do(s) título(s) descarregado(s) para outro fim, designadamente comercial, carece de autorização do respetivo autor ou editor da obra.

Na medida em que todas as obras da UC Digitalis se encontram protegidas pelo Código do Direito de Autor e Direitos Conexos e demais legislação aplicável, toda a cópia, parcial ou total, deste documento, nos casos em que é legalmente admitida, deverá conter ou fazer-se acompanhar por este aviso.

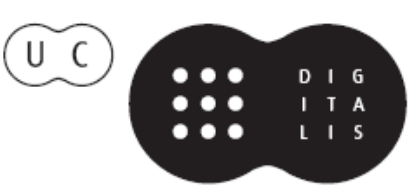




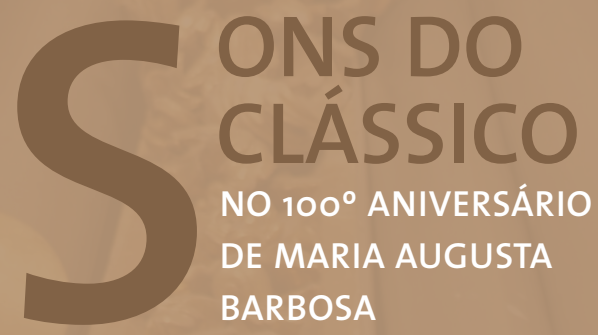

J. M. Pedrosa Cardoso

Margarida Lopes de Miranda COORDENAÇÃO 
(Página deixada propositadamente em branco) 


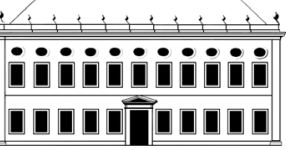

D

0

C

M

E

N

T

0

S<smiles>C[C@]12CC[C@@](C)(C1)C2</smiles> 


\title{
EDIÇÃO
}

Imprensa da Universidade de Coimbra

URL: http://www.uc.pt/imprensa_uc

Email: imprensauc@ci.uc.pt

Vendas online: http://www.livrariadaimprensa.com

\section{CONCEÇÃO GRÁFICA \\ António Barros}

IMAGEM DA CAPA

Orgão da Capela de São Miguel da Universidade de Coimbra, Sérgio Brito, UC • DIIC, 2010.

\section{INFOGRAFIA DA CAPA \\ Carlos Costa}

INFOGRAFIA

Xavier Gonçalves

EXECUÇÃO GRÁFICA

www.artipol.net

ISBN

978-989-26-0529-6

ISBN Digital

978-989-26-0567-8

DOI

http://dx.doi.org/10.14195/978-989-26-0567-8

\author{
DEPÓSITO LEGAL \\ $352794 / 12$
}

OBRA PUBLICADA COM O APOIO DE:

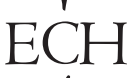

FC

Fun
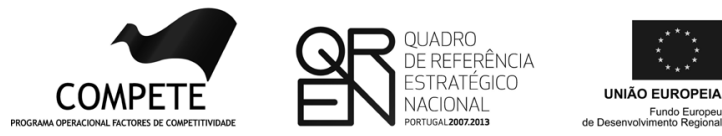

C DEZEMBRO 2012, IMPRENSA DA UNIVERSIDADE DE COIMBRA 


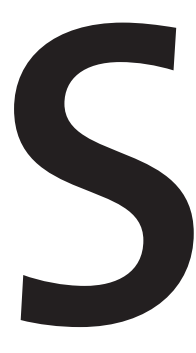

ONS DO

CLÁSSICO

NO $100^{\circ}$ ANIVERSÁRIO

DE MARIA AUGUSTA

BARBOSA

J. M. Pedrosa Cardoso

Margarida Lopes de Miranda

COORDENAÇÃO 
(Página deixada propositadamente em branco) 


\section{SUMÁRIO}

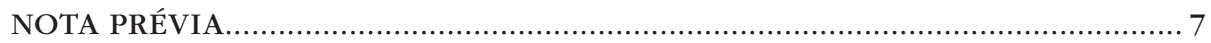

Maria do Céu Fialho

MARIA AUGUSTA BARBOSA: EXEMPLO DE SABER E HUMANIDADE. 9

José Augusto Cardoso Bernardes

ABERTURA 13

MARIA AUGUSTA ALVES BARBOSA: QUADRO DE UMA CENTENÁRIA .17

AS CURVAS DO MEU PERCURSO 21

Maria Augusta Barbosa

DEBAIXO DO FOGO: A MÚSICA EM TEMPO DE GUERRA 31

Maria Augusta Barbosa

VON DER MUSIKALISCHEN FARBE: DER DISKURS ÜBER CHROMA

UND COLOR IN MITTELALTER UND RENAISSANCE .... 35

Klaus Wolfgang Niemöller

DIEGO BUXEL (? - †POST 1572) EM COIMBRA

Pedro Carlos Lopes de Miranda

DA PRÁTICA MUSICAL NO MOSTEIRO DE SANTA MARIA DE SEMIDE. 59 Amparo Carvas Monteiro

MÚSICA E DANÇA NA TRAGICOMÉDIA DO REI DOM MANUEL, DE ANTÓNIO DE SOUSA (1619) 79

Maria Margarida Lopes de Miranda 
EM BUSCA DO PECULIAR NA MÚSICA SACRA PORTUGUESA

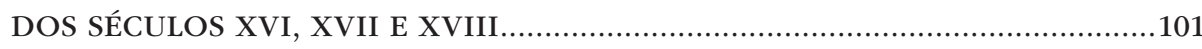

José Maria Pedrosa Cardoso

AS REPRESENTAÇÕES DA MÚSICA NA ARTE PORTUGUESA:

CONTRIBUTO PARA UM BANCO DE DADOS ICONOGRÁFICO

Maria Adelina Amorim e Vitor Serrão

A MÚSICA NAS OBRAS MÉTRICAS DE

D. FRANCISCO MANUEL DE MELLO

Rosa Teresa Paião Picado

AS VINTE CANTATAS A DÚO (LISBOA, c1724)

DE JAIME DE LA TÉ Y SAGÁU 171

Gerhard Doderer

EZIO DE NICCOLO JOMMELLI PARA LISBOA:

MEDIAÇÃO ENTRE A TRADIÇÃO E A INOVAÇÃO

Márcio Páscoa

EM BUSCA DO CONTEXTO:

MARIA AUGUSTA BARBOSA E EDUARDO LIBÓRIO .211

Gil Miranda

O PROJECTO DE ENCOMENDAS DE MÚSICA PARA BANDA DA S.E.C.

DE 1977 A 1983: CONTEXTUALIZAÇÃO E OBSERVAÇÕES INICIAIS

André Granjo

RELENDO KARL R. POPPER. .251

Maria do Rosário Themudo Barata

A INVESTIGAÇÃO EM MÚSICA NO ENSINO SUPERIOR. .259

Mário Vieira de Carvalho

A ETNOMUSICOLOGIA NA UNIVERSIDADE NOVA DE LISBOA:

OS PRIMEIROS ANOS 273

Salwa El-Shawan Castelo-Branco 


\section{NOTA PRÉVIA}

As Línguas Clássicas nasceram no seio da música, com o seu acento de altura e o seu ritmo compassado de breves e longas, em que a poesia, mas também o discurso médico, historiográfico, a interrogação filosófica e a mais simples ou mais íntima, terna ou sofrida comunicação do quotidiano tomavam corpo.

Não admira, pois, que, no contexto da festa, fosse ela banquete convivial ou festa cultual e política da cidade, as representações artísticas primassem por uma dimensão de arte total, em que música, palavra e dança se uniam, numa expressão integral do homem.

Este convívio entre as Musas (de que a Música colheu o nome) e o quotidiano ditou uma peculiar forma de herança e de recepção, tão rica e tão óbvia que seria pretensioso lembrá-lo aqui. De sublinhar, sim, é essa vocação de sympatheia entre os Estudos Clássicos e os Estudos Musicais. Perceberam-no, aquando da criação do Mestrado em Ciências Musicais na Faculdade de Letras da Universidade de Coimbra, a Doutora Maria Augusta Barbosa, sua cofundadora juntamente com o Prof. Doutor Gerhard Doderer, e o Conselho Científico, à altura presidido por uma insigne Classicista, a Doutora Maria Helena da Rocha Pereira.

E essa sympatheia foi mais longe: desde logo, foi sendo, pela Doutora Maria Augusta Barbosa e, posteriormente, pelo Doutor José Maria Pedrosa Cardoso, seu discípulo mais próximo, pedida a colaboração de classicistas na docência do Mestrado. Por ele passaram os Doutores José Geraldes Freire, Sebastião Tavares de Pinho, Carlos Manuel Bernardo Ascenso André, Maria Margarida Lopes de Miranda. Actualmente, presta colaboração com a área de Música dos Estudos Artísticos, também o Doutor Frederico Maria Bio Lourenço. 
Ainda em vida da Doutora Maria Augusta Barbosa, passou o Centro de Estudos Clássicos e Humanísticos, a que todos estes classicistas mencionados pertencem como Investigadores Integrados, a contar com um Musicólogo na sua equipa: o Doutor Pedrosa Cardoso, colaborador sempre disponível com o seu saber e capacidade comunicativa, já tão comprovada em congressos e publicações da equipa do Centro.

Não poderia, pois, o Centro de Estudos Clássicos e Humanísticos deixar de se associar, com todo o entusiasmo, a este gesto de homenagem, traduzido pela presente publicação científica colectiva. Sobre ela se elevam, em uníssono, todas as vozes que a música ancestral e o estudo da música combinaram - os sons do Clássico.

Maria do Céu Fialho

Coordenadora Científica do Centro de Estudos Clássicos e Humanísticos 


\section{MARIA AUGUSTA BARBOSA: EXEMPLO DE SABER E HUMANIDADE}

A doação de uma biblioteca pessoal implica atributos e circunstâncias muito especiais. Da parte do dador, para além de uma grande generosidade, implica uma confiança ilimitada no recetor escolhido. É assim com todos os dadores de todas as bibliotecas. Todavia, quando se trata de um acervo especializado, a doação constitui ainda um investimento de fé, o prolongamento de uma luta que se travou por uma causa, muitas vezes quase a sós, uma esperança num passar de testemunho, para que essa causa se acrescente.

Foi decerto o que aconteceu com a Doutora Maria Augusta Barbosa quando, há 10 anos, decidiu entregar os seus livros (e também os seus discos) à Biblioteca Geral da Universidade de Coimbra. Houve muitos fatores que pesaram nessa atitude. $O$ primeiro tem que ver com a ligação da ilustre professora à nossa Universidade, iniciada em 1986. De facto, logo depois de se jubilar como Professora da Universidade Nova de Lisboa, Maria Augusta Barbosa aceitou o convite que lhe foi dirigido pela Faculdade de Letras para fundar, em Coimbra, o Mestrado em Ciências Musicais (em estreita colaboração com o Doutor Gerhard Doderer, seu colaborador muito direto). Ao longo de mais de uma década, esse novo Curso atraiu um conjunto considerável de investigadores (na sua maioria muito jovens) que se dedicaram maioritariamente à investigação de documentos do fundo musical da Biblioteca Geral, chamando ainda mais a atenção para a sua riqueza, no plano nacional e internacional.

14 anos depois, a Doutora Maria Augusta viria ainda a participar no grupo que, na Faculdade de Letras, concebeu um Curso de Estudos Artísticos, incorporando a componente musical, a par do Cinema e do Teatro. Esse Curso, para 
cujo desenho forneceu um importante contributo (seguramente inspirado no conhecimento que tinha de outros cursos que funcionavam no estrangeiro), viria a iniciar-se em 2002/2003, acrescentando à Universidade de Coimbra em geral, algo que lhe faltava de forma flagrante e quase inexplicável. Um outro fator que deve ter pesado na sua decisão foi o conhecimento que a Professora e investigadora incansável tinha das riquezas do nosso espólio documental, no que diz respeito à Música. Por experiência própria, Maria Augusta Barbosa sabia que os seus livros, os seus documentos e os seus discos viriam para boa companhia, juntando-se a uma vasta, rica e ainda inexplorada mole bibliográfica e documental, já existente em Coimbra. Por fim, deve ter-lhe inspirado confiança decisiva a pessoa que então dirigia a Biblioteca Geral. Sou testemunha de que as relações entre a Professora de Lisboa e o Doutor Aníbal de Castro se pautaram sempre por uma grande admiração mútua: a admiração natural entre duas pessoas que, para além de muitas diferenças de idiossincrasia, tinham uma mesma ideia de Universidade, pautada pelo rigor e pela abnegação, indispensáveis em todos os que a ela se consagram.

Foi assim que, em Janeiro de 2002, resolvidas as questões legais, ao mesmo tempo que a doadora entrava na Casa de Saúde e Repouso da Amoreira, onde passou a residir, chegaram à nossa Biblioteca as embalagens que continham o seu legado. Trata-se de uma biblioteca vasta e diversificada porque, apesar de grande especialista num ramo do saber, a sua possuidora detinha e alimentava uma infatigável curiosidade por muitas outras áreas. Mas o núcleo mais rico desse conjunto é constituído pela componente musical: temos, desde logo, gravações preciosas em discos e CDs; e temos, depois, muitos documentos arquivados em fotocópia e em microfilme, recolhidos em várias fontes, em especial situadas na Alemanha, país onde a nossa doadora fez grande parte da sua formação. De todo esse conjunto, merecem destaque os Tratados de Teoria musical quinhentista, tema a que se dedicara já na sua dissertação de doutoramento e pelo qual continuou a interessar-se, de forma regular, a ponto de se constituir, nessas matérias, numa verdadeira autoridade mundial.

Para além da componente bibliográfica e discográfica, a doação da Doutora Maria Augusta Barbosa à Biblioteca Geral inclui ainda um objeto de grande valor material e emocional: falamos do seu piano (um piano de cauda) que 
foi instalado no edifício da Biblioteca Joanina, passando a servir nos vários atos artísticos que naquele espaço se realizam, ao longo do ano.

A braços com falta de pessoal qualificado, a Biblioteca Geral não pôde ainda corresponder convenientemente à generosidade da doação feita, procedendo à catalogação do acervo, de modo a torná-lo completamente disponível ao público. Sei que essa preocupação atormentava a consciência dos dois colegas que me antecederam no cargo da mesma forma que agora me atormenta a mim. Mas existe esperança e existe projeto. Em tempos de grande escassez de meios próprios, a esperança reside sobretudo nas instituições especialmente vocacionadas para acudir a casos destes, às quais nos dirigiremos, no futuro, ainda com mais insistência. O projeto que acalentamos envolve a Biblioteca da Doutora Maria Augusta Barbosa e outros espólios congéneres que temos à nossa guarda (refiro, em especial, aquele que pertenceu ao Tenente Manuel Joaquim, também entrado por iniciativa diligente do Doutor Aníbal de Castro). Trata-se, efetivamente de criar na Biblioteca universitária maior e mais antiga de todo o mundo lusófono uma Sala de Música. Graças à generosidade de alguns, temos material mais do que suficiente para dar corpo a essa ambição. Aguardamos agora que outras generosidades possam congregar-se, no sentido de dar corpo a um desejo antigo, que nos parece de grande alcance patrimonial e que, depois de levado à prática, colocará a Biblioteca Geral da Universidade de Coimbra como lugar prioritário de investigação no campo das ciências musicais.

Enquanto essa bem fundada esperança não se concretiza, só podemos reiterar a nossa gratidão à ilustre doadora, associando-nos, nesta data tão especial, a todos aqueles (e são muitos) que foram sendo contemplados com o seu saber e a sua humanidade.

Coimbra, 8 de Fevereiro de 2012

O Diretor da Biblioteca Geral

José Augusto Cardoso Bernardes 
(Página deixada propositadamente em branco) 


\section{ABERTURA}

Este livro vem, de algum modo, fazer justiça a uma senhora que, durante uma vida centenária (1912-2012), deu o melhor de si mesma ao estudo e ao ensino da música na sua vertente científica.

Maria Augusta Barbosa investiu grande parte dos seus anos no estudo: aos 31 anos, após a conclusão dos cursos superiores de Piano e de Composição no Conservatório Nacional de Lisboa, concluiu a sua licenciatura em Ciências Musicais na Universidade Humboldt de Berlim e aos 58 obteve o grau de Doctor Philosophiae, área de Ciências Musicais, na Universidade de Colónia.

No Conservatório Nacional fez duas etapas: a primeira, por força da II Grande Guerra, durante 13 anos, aceitando um convite do Director, Dr. Ivo Cruz, e a segunda, durante 9 anos, compelida pelo Director Geral do Ensino Superior a regressar ao país.

O resto da sua vida, foi o ensino universitário: primeiro, na Universidade Nova de Lisboa, onde aliás viu reconhecido o seu doutoramento, e onde criou a primeira licenciatura em Ciências Musicais em Portugal, aí permanecendo até à sua jubilação (1982), e logo, gratuitamente, na Universidade de Coimbra e na Universidade de Lisboa, prestando ainda notável contributo na Universidade Autónoma e na Universidade Lusíada. E foi em plena actividade nas Universidades de Coimbra e Lusíada que viu chegar ao fim, em 2001, aos 89 anos, inesperadamente para ela, a sua carreira universitária.

Maria Augusta Barbosa foi uma mulher singular. Amada por muitos, embora malquista por uns poucos, foi admirada por todos os que trabalharam com ela. Efectivamente, dotada de temperamento espartano, suficientemente moldado pelo clima alemão, era modelo de entrega e tenacidade no seu 
trabalho. Como confessa em certo relatório, feito já no Lar, a propósito do tempo da Universidade Nova, "(...) passei estes dois anos inteiramente ligada, de $2^{\mathrm{a}}$ a $6^{\mathrm{a}}$ feira, entre as 9 horas da manhã e as 8 horas da noite, à Faculdade, hora que esta fechava". A sua capacidade de trabalho era bem conhecida por todos os que trabalharam com ela, desde Colónia - "Ich hatte damals schon grösste Hochachtung von Ihrer Arbeitsintensität und Ihrer Disziplin» (Prof. Klaus W. Niemöller) - até aos tempos de Coimbra, onde se multiplicava em esforços para arrastar os alunos ao sucesso. O rigor que se impunha a si mesma, na sua investigação e na qualidade dos seu trabalho, denunciando a sua exigência a colegas e alunos, pode explicar o facto de ter publicado apenas um livro, já na sua maturidade, o seu Vincentius Lusitanus: ein portugiesischer Komponist und Musiktheoretiker des 16. Jabrhunderts (Lisboa: Secretaria de Estado da Cultura e Direcção-Geral do Património Cultural, 1977).

Conquistando simpatias por onde passava, através de afabilidade, mulher de enorme resistência tanto física como psíquica e moral, apostando sempre na vitória sobre os obstáculos - tinha dificuldade em gerir o fracasso que, no limite, se opunha ao seu caminho - como primeira doutorada portuguesa em Ciências Musicais, foi pioneira do percurso académico da Musicologia em Portugal, à qual deu significativo contributo tanto no seu exemplo como na criação de Departamento de Ciências Musicais na Universidade Nova de Lisboa e, logo a seguir, na criação e posterior direcção dos cursos de Mestrado e Doutoramento naquela área científica na Universidade de Coimbra.

Mulher unius libri, no sentido pleno da expressão, gastava todo o seu dinheiro em adquirir livros, pelos quais se sentia e confessava bibliodependente. De aí o valor da sua biblioteca que, após diversas hesitações, acabou por doar à Biblioteca Geral da Universidade de Coimbra, onde se espera venha a merecer a sala prometida com o seu nome. Daí também a justiça que se lhe faz com a presente edição, que, sob um título clássico muito à medida da sua personalidade, reúne capítulos da Teoria à História da Música e das Artes, da autoria de personalidades que privaram ou simplesmente conheceram Maria Augusta Barbosa, tais como Klaus W. Niemöller, Gerhard Doderer, Ivo Miranda, Mário Vieira de Carvalho, Salwa Castelo-Branco, Vítor Serrão, Márcio Páscoa e outros colegas e alunos. 
Agraciada pela Secretaria de Estado da Cultura em 1987, com a Medalha de Mérito Cultural, dedicatária de um número da Revista Portuguesa de Musicologia $\left(n^{\circ} 12,2002\right)$ na celebração dos seu $90^{\circ}$ aniversário, esta é a homenagem possível que Maria Augusta Barbosa mereceu, na celebração do seu $100^{\circ}$ aniversário, como mulher notável e como nome grande e indispensável na Musicologia em Portugal.

Universidade de Coimbra, Janeiro de 2012

José Maria Pedrosa Cardoso

Margarida Miranda 
(Página deixada propositadamente em branco) 


\section{MARIA AUGUSTA ALVES BARBOSA: QUADRO DE UMA CENTENÁRIA}

1912 - Nasce em Lisboa, a 18 de Abril.

1936 - Termina os cursos superiores de Piano (com Viana da Mota) e Contraponto e Fuga (com António Eduardo da Costa Ferreira) no Conservatório Nacional com notas máximas.

1937 - Estagia em Paris, onde estuda com Louis Lalloy (História da Música) e Nadia Boulanger (Composição). No Verão deste ano, passa duas semanas na Abadia de Solesmes, estudando com Dom Joseph Gajard. 1938 - Obtém uma bolsa de estudo de longo prazo do Instituto de Alta Cultura em Ciências Musicais, partindo em Outubro para Berlim.

1943 - Conclui a licenciatura em Ciências Musicais na Universidade Humboldt de Berlim, tendo como professores principais Hans Mersmann, Johannes Wolf e Arnold Schering.

1943 - É compelida a abandonar Berlim, por razões de segurança, e regressar a Portugal.

1945 - A convite do Dr. Ivo Cruz, é professora de Acústica e História da Música no Conservatório Nacional.

1958 - Após a frequência de dois semestres, legalmente obrigatórios na Universidade de Colónia, prepara o seu doutoramento sob a orientação de Karl-Gustav Fellerer, fazendo investigação em vários países da Europa. 1970 - Conclui as suas provas de doutoramento em Ciências Musicais na Universidade de Colónia, sobre o tema «Vincentius Lusitanus, ein portugiesischer Komponist des XVI. Jahrhunderts». 
1971 - Inicia trabalhos de investigação em Colónia, com uma bolsa do Centro Alemão de Investigação, bolsa rejeitada pela Direcção Geral do Ensino Superior, tendo que regressar ao Conservatório Nacional.

1977 - Publica a sua tese com o título de Vincentius Lusitanus: ein portugiesischer Komponist und Musiktheorethiker des 16. Jahrbunderts. Lisboa: Secretaria de Estado da Cultura, Direcção-Geral do Património Cultural. 1979 - O seu grau de «Doctor Philosophiae» pela Universidade de Colónia é declarado equivalente ao doutoramento em Ciências Musicais pela Universidade Nova de Lisboa.

1980 - Funda o Departamento de Ciências Musicais na Universidade Nova de Lisboa, onde desempenha funções docentes e de coordenação.

1983 - Atingindo o limite de idade, é professora jubilada da Universidade Nova de Lisboa.

1986 - Funda, com o Prof. Gerhard Doderer, o Mestrado em Ciências Musicais na Faculdade de Letras da Universidade de Coimbra.

1987 - É agraciada com a Medalha de Mérito Cultural da Secretaria de Estado da Cultura.

1989-1990 - Ministra uma cadeira de História da Música na Universidade Autónoma.

1990-1995 - Dá a cadeira de História da Música, a convite do Prof. Doutor Veríssimo Serrão, no Mestrado de História e Cultura do Brasil, na Faculdade de Letras da Universidade de Lisboa.

1991-2001 - Inicia a leccionação de História da Música na Universidade Lusíada 2000 - Empenha-se, juntamente com outros professores, no projecto de uma nova licenciatura em Estudos Artísticos, que abrirá no ano lectivo de 2002-2003.

2001 - No mês de Dezembro, é internada com urgência no Hospital de Santa Maria.

2002 - Em Janeiro, passa a residir na Casa de Saúde e Repouso da Amoreira, tendo entregue a sua biblioteca à Biblioteca Geral de Universidade de Coimbra.

2012 - Aos 18 de Abril, cumpre festivamente 100 anos 2012 - A 24 de Abril, expira no Hospital de Loures. 


\section{Bibliografia}

Vincentius Lusitanus: ein portugiesischer Komponist und Musiktheoretiker des 16. Jabrbunderts. Lisboa: Secretaria de Estado da Cultura, 1977

"Einführung in die Musikgeschichte Portugals bis zur Mitte des 17. Jahrhunderts", Separata de Ars Musica - Ars Scientia. Festschrift Heinrich Hüschen, Köln, Gitarra und laute Verlags Gesellschaft, 1980, p. 22-29. 
(Página deixada propositadamente em branco) 
Maria Augusta Barbosa

\section{AS CURVAS DO MEU PERCURSO ${ }^{1}$}

\section{Em jeito de introdução}

Por vários lados - e de há muito tempo já - tem-me vindo a ser pedido um relato das minhas actividades ao longo da minha vida profissional. Tenho-me sempre esquivado, na convicção de que os factos - bem ou mal - por si falam, e não vale a pena, portanto, focá-los em especial.

Mas a insistência continua e tem-me sido dito até que o meu silêncio pode dar azo a que, por desconhecimento, se venham a fazer afirmações menos certas em relação à obra realizada. E decidi-me então [...]

\section{Relato das minhas actividades}

Nasci em Lisboa, no dia 18 de Abril de 1912.

A natural inclinação que, durante a infância e a juventude, eu ia revelando para a música, levou os meus pais a orientar os meus estudos também nesse sentido. E após cuidadosos e prolongados estudos a nível particular, sempre sob a orientação de professores especializados nas áreas do ensino liceal e da música, sem esquecer a preparação visando o domínio teórico-prático das línguas francesa, inglesa e italiana, matriculei-me no Conservatório Nacional de Lisboa, único estabelecimento oficial que ao tempo, em matéria do ensino da música, existia em Portugal.

\footnotetext{
1 Título da nossa autoria.
} 
Matriculei-me nos cursos superiores de piano e de contraponto e fuga, respectivamente nas aulas dos professores José Vianna da Motta (piano) e António Eduardo da Costa Ferreira (contraponto e fuga). Terminei estes dois cursos respectivamente com 19 e 20 valores, tendo obtido classificações igualmente elevadas nos exames dos cursos de música, geral e complementar, que me haviam dado acesso aos cursos superiores acima referidos. Após a conclusão destes últimos, parti para Paris onde, durante um ano lectivo, frequentei as aulas de História da Música dirigidas pelo Prof. Louis Lalloy, no Conservatório de Música desta cidade e me aperfeiçoei em composição - prolongamento do curso de contraponto e fuga - agora sob a orientação particular da Prof ${ }^{a}$ Nadia Boulanger, ao tempo uma das mais afamadas autoridades nesta matéria, à escala internacional.

Regressei a Portugal no final desse ano lectivo, com o objectivo de me preparar, com serenidade e segurança, para um concurso a uma bolsa de estudos de longo prazo, que o Instituto de Alta Cultura anunciara ir abrir também em matéria de Ciências Musicais. Concorri e ganhei. Uma condição, porém, me era imposta: os estudos deviam ser feitos na Alemanha. À minha objecção de que eu não sabia alemão, foi respondido secamente e com determinação: se não sabe, aprenda-o.

Parti para Berlim nesse ano - Outubro de 1938 - e aí encontrei na matéria que me havia levado lá e que se não ensinava em Portugal, professores extraordinários e um nível de conhecimentos que respondia ao que eu procurava e que justificava plenamente as directivas recebidas.

Hans Mersmann, Johannes Wolf e Arnold Schering, que já faleceram, foram os professores universitários que desde logo orientaram os meus primeiros passos no sentido dos novos estudos e os guiaram até ao fim dos oito semestres requeridos pelas universidades alemãs para conclusão deste Curso de Ciências Musicais, equivalente a qualquer Curso das nossas Licenciaturas em Letras.

O meu primeiro semestre em Berlim, entre Outubro de 1938 e Fevereiro de 1939, foi consagrado intensivamente ao estudo da língua alemã, sem que eu todavia pusesse de lado os possíveis contactos com as matérias da especialidade, usando do conhecimento que tinha das línguas francesa e inglesa.

A aprovação no exame, escrito e oral, da língua alemã abriu-me o acesso à matrícula na Humboldt Universität, em Berlim. Depois, entre Fevereiro de 
1939 e Julho de 1943, levei a termo, com êxito, os oito semestres requeridos pela Universidade, apesar das dificuldades inerentes à qualidade de língua exigida numa faculdade e à vida num país em guerra, com as carências de alimentação difícil não obstante a extraordinária organização alimentar estabelecida e, por outro lado, a intensificação progressiva dos bombardeamentos.

Terminados os oito semestres requeridos pelo curso, tentei começar a recolher elementos para uma tese de doutoramento.

Ao cabo destes anos de luta, várias cidades tinham sido completamente arrasadas pelo progredir da guerra. E agora, após Hamburgo, Nurenberg e outras, era Berlim que estava em linha.

Regressei portanto a Portugal em Agosto de 1943, quando Hitler aconselhou mulheres e filhos de diplomatas a regressar aos seus países, porque não podia - disse - tomar a responsabilidade pelo que viesse a acontecer. Era de resto impossível proceder, no tempo de então, às investigações de que eu carecia. Por outro lado, fui fortemente aconselhada a regressar, pelas autoridades portuguesas diplomáticas na Alemanha. O perigo era grande, como a seguir se verificou.

Pouco depois de chegar a Portugal, fui convidada pelo Director do Conservatório Nacional - Dr. Ivo Cruz - a substituir o Prof. Eduardo Libório, recentemente falecido, na regência das disciplinas de Acústica e História da Música, de que ele fora detentor. Desempenhei este lugar de 1945 até fins de 1958, tendo conseguido tornar possível, aos meus alunos, a vivência regular dos valores musicais que eles aprendiam a conhecer histórica e analiticamente nas aulas, agora também nas próprias salas de espectáculo (óperas, bailados, concertos de orquestra, de "camera" e a solo) sempre gratuitamente, por gentileza e compreensão dos directores das respectivas organizações. Os intervalos eram sistematicamente preenchidos por trocas de impressões e de critérios analíticos entre os alunos e o professor, que sempre os acompanhava.

Sob pressão de amigos e do próprio Instituto de Alta Cultura, parti então de novo para a Alemanha, a fim de efectuar o doutoramento em Ciências Musicais (também com subsidio do Instituto de Alta Cultura), desta vez na Universidade de Colónia, já que a Humboldt Universität, em Berlim, onde eu havia feito o curso, estava agora localizada na zona Leste da Alemanha, com a qual Portugal não tinha relações diplomáticas. Em Colónia tive, por orientadores 
de tese, o meu anterior professor de Berlim, Prof. Doutor Hans Mersmann, que entretanto tinha fixado residência em Colónia, e o Prof. Doutor Karl-Gustav Fellerer, Director do Instituto de Ciências Musicais da Universidade de Colónia.

Foi-me modificado o tema de tese para outro em si mais complexo e fui obrigada a frequentar dois novos semestres nesta Universidade, por imposição de lei, que exigia esta frequência, com a apresentação dos respectivos trabalhos de seminário, a todos os alunos que transitassem de uma para outra Universidade na Alemanha, mesmo que tivessem já o curso concluído e a nova ligação à Universidade tivesse por objectivo o doutoramento.

A matéria do novo tema focava uma difícil querela renascentista sobre teoria modal, em que se tinham azedamente envolvido, por um lado, um músico português, compositor e teórico musical de valor e, por outro, um músico italiano da corte do poderoso Cardeal de Ferrara, músico igualmente teórico musical de elevado nível. Esta questão havia tomado agudas proporções e juntado, para julgamento em Roma, na Capela Papal, dois cantores / compositores desta mesma Capela e a corte cardinalícia. A temática evocava um dos problemas teórico-musicais mais escaldantes na época, porque era tempo de reforma em estrutura musical e técnica de composição.

Por outro lado ainda, eram desconhecidos dados biográficos do músico português. Apenas se supunha ser oliventino e se sabia estar ligado à casa do embaixador português em Roma, em meados do século xvi, D. Alexandre de Lencastre, e a seu filho, D. Dinis. Todos estes factos iriam mexer muito com questões de história, algumas ainda desconhecidas, obrigando a investigações de fundo, inevitavelmente demoradas. Foi necessário investigar em países diversos: Portugal (Lisboa, Coimbra, Braga, Évora, Elvas, e alguns arquivos de vilas alentejanas fronteiriças); Espanha (Madrid, Salamanca, Simancas, Escoriai, Badajoz, Olivença), Bélgica (Bruxelas), França (Strassburg, Paris); Alemanha (Munique, Ludwígsburg); Itália (cidades várias, entre as quais Roma, Pádua, Veneza, Viterbo, Bolonha).

Necessariamente demoradas, as investigações foram sempre apontadas para as Bibliotecas e Arquivos dos locais onde se admitia a hipótese de se virem a encontrar elementos de interesse para a tese em curso.

Concluída esta tese e prestadas as inerentes provas de doutoramento [no ano de 1970], de discussão oral, foi-me oferecida, por intermédio de um dos meus 
orientadores de tese - o Prof. Doutor Karl-Gustav Fellerer - uma bolsa de estudo do governo alemão - que na Alemanha apenas se concede a doutorados -, para que eu pudesse estudar e publicar um tratado manuscrito de muito valor, anónimo, que é de certeza de um músico português quinhentista que se havia fixado no estrangeiro. Apesar de recomendações e de solicitações várias de professores universitários alemães e de outras influências que se moveram, a Directora do Conservatório Nacional, ao tempo, a seguir ao Dr. Ivo Cruz que atingira a idade da reforma, em conjunto com o Director Geral do Ensino Superior, impediram que eu aceitasse a bolsa, a fim de que regressasse ao Conservatório Nacional para ensinar Acústica e História da Música - como o fizera antes do Doutoramento - agora apenas a 3 alunas com preparação cultural muito limitada. Eu tinha, nesta altura, o trabalho sobre esse manuscrito em certo andamento e até mesmo quem estivesse interessado em o publicar, trabalho que eu tinha em mente, logo que terminado - o que duraria um máximo de dois anos - apresentar como tese de agregação na Universidade de Colónia, para avançar na carreira universitária, ao mesmo tempo que fazia currículo com um estudo de muito interesse para a nossa cultura. O que então teria sido possível, não o foi depois.

Em Portugal, retomei o meu antigo lugar no Conservatório Nacional, tendo--me também então sido proibido, pela mesma Directora, que eu elaborasse os programas das minhas próprias aulas. Estes foram-me impostos. Os alunos deste ano e os do ano seguinte reagiram fortemente contra, e com razão; mas concordaram com aqueles que lhes dei logo a seguir ao 25 de Abril. Não se esqueça que eu era, nessa altura, o único cidadão português, no mundo inteiro, doutorado em Ciências Musicais, e nelas plenamente actualizado, vindo donde vinha.

Mas é evidente que eu não podia ficar aqui limitada a uma situação sem horizontes e até vexatória.

O 25 de Abril veio franquear-me uma nova pista, em parte sugerida pelo Prof. Gerhard Doderer, em vésperas de doutoramento, pista que já como que me aflorara, mas que eu, desiludida, talvez não tivesse seguido, não fora a forte pressão de G. Doderer: uma licenciatura em Ciências Musicais numa Universidade Portuguesa.

Um estudo deste problema entre mim, o Prof. Doderer e o Prof. Doutor Henrique de Oliveira Marques, Director ao tempo da Faculdade de Ciências Humanas e Sociais da Universidade Nova de Lisboa, preparou o terreno. 
Gerhard Doderer regressou à Alemanha para concluir o doutoramento; eu fiquei com o encargo de estruturar a nova licenciatura, programas inclusive, e seleccionar o núcleo docente dentro do que fosse de momento possível.

A nova licenciatura foi superiormente legalizada e ainda hoje perdura, em permanente renovação, na Faculdade de Ciências Humanas e Sociais da Universidade Nova de Lisboa.

No decurso destes primeiros tempos ia-nos caber igualmente a tarefa superior de começar a formar o futuro quadro docente deste novo ramo, o de Ciências Musicais, na Universidade Portuguesa.

De momento apenas consegui reunir, embora sem o necessário enquadramento oficial, mas com sólida preparação especializada de base, o Prof. Dr. João de Freitas Branco e a Prof ${ }^{a}$. Constança Capdeville, que haviam feito a sua elevada preparação cultural, a nível pessoal e que se revelaram neste ensino à altura das suas novas funções.

Veio juntar-se-lhes, um ano mais tarde, Gerhard Doderer, doutorado havia pouco tempo, igualmente nesta matéria, na Alemanha, na Universidade de Würzburg e, ainda algum tempo depois, Salwa Castelo Branco recentemente também doutorada, na mesma matéria, mas na Universidade de Nova York.

Ambos iriam adquirir a nacionalidade portuguesa e fixar-se em Portugal; são ambos hoje professores catedráticos da mesma faculdade.

A licenciatura em Ciências Musicais começou a funcionar em Outubro de 1980. A partir daí - e durante os dois anos seguintes - estruturei-a, orientei os programas de ensino fixados por lei, apetrechei-a com a aparelhagem que me foi dado adquirir e com a bibliografia de especialização que pude conseguir, recorrendo a centros e fundações culturais, bibliografia de que a Universidade Nova estava desprovida.

Organizei portanto a sua estrutura lectiva como a sua estrutura administrativa, no primeiro ano sem auxílio nenhum, no segundo tendo conseguido que me fosse adjudicado ao serviço um oficial de $3 a$, que ainda hoje continua ligado ao Departamento.

Na convicção de que era indispensável dar ao nosso ensino a devida projecção, dei azo, com a colaboração do Ministério da Educação e do Goethe-Institut, a realizações artístico-culturais, portanto num enquadramento internacional, neste caso sempre luso-alemão. 
Para dar aulas, lançar mãos de todos estes trabalhos, atender pessoas de fora que me procuravam para assuntos relacionados com o novo Departamento e, sobretudo, falar com os alunos, em conjunto ou em particular, e até ir ao Ministério da Educação, resolver assuntos que só pessoalmente podiam ser rapidamente tratados, passei estes dois anos inteiramente ligada, de 2.a a 6.a feira, entre as 9 horas da manhã e as 8 horas da noite, à Faculdade, hora a que esta fechava.

No final de 1982, eu tinha atingido os 70 anos de idade, limite máximo de tempo, para poder exercer as funções que estava a exercer. Tinha também 44 anos de serviço (1938-1982), porque a lei considerava então para efeitos de contagem de anos para reforma, o tempo de uma bolsa de estudos oficial, se esta tivesse revertido em benefício do país. Nunca me preocupei com o tempo que podia exceder os limites normais da minha actividade profissional, mas não estava - isso sim - interessada em ficar de braços cruzados.

Neste tempo de trabalho não me foi reconhecida, porém, a exclusividade. À minha reclamação foi respondido que a exclusividade era um simples subsídio, sem direito portanto à reforma. Cerca de um ano depois, eram diferentes os critérios; mas não fui por eles abrangida.

Terminado o meu tempo oficial de trabalho, mas sentindo eu - e os médicos consultados também - que ainda estava em condições físicas e mentais de continuar a levar por diante o projecto que tinha lançado, comecei a pensar na fundação de um mestrado em Ciências Musicais, apontando desta vez, porém, para a Universidade de Coimbra.

Conseguimos abri-lo em 1986, o Prof. Doutor G. Doderer e eu, como mestrado independente e também um pouco como pé de entrada, na esperança de poder vir um dia a criar, nesta mesma Universidade, a respectiva licenciatura.

Na programação dos seminários esteve sempre em vista a preparação do mestrando para um trabalho de investigação tendente a valorizar a cultura portuguesa, dos tempos antigos á actividade.

Daí a persistência no ensino do latim e da paleografia geral, como estavam em uso nos velhos tempos de Portugal, além das matérias da especialidade, estas variáveis de mestrado para mestrado, à luz de uma visão abrangente do conjunto Portugal/Europa. 
Este mestrado tem continuado a funcionar regularmente até ao tempo presente, tendo assim aberto o caminho, nas diversas linhas da especialidade, a um número já considerável de mestrandos, hoje mestres, todos até agora com boas colocações e com boas perspectivas de futuro. Orientados que foram no sentido de um trabalho correctamente estruturado e cientificamente elaborado, com base na análise e na investigação histórica, alguns concluíram já o doutoramento, outros estão a prepará-lo. A escolha dos temas de dissertação e de tese de doutoramento tem vindo continuamente a recair, como havia sido projectado, sobre temática de cultura musical portuguesa, nos seus diferentes quadrantes, - no sentido histórico, teórico e de música prática - trazendo á luz do dia provas da nossa cultura, que há muito viviam esquecidas no silêncio de arquivos e bibliotecas, dentro e fora do país.

Na sequência do esforço feito até hoje neste sector, verifica-se um fervilhar de interesses por este ramo de actividade e até mesmo algumas perspectivas de uma boa abertura à edição de novos estudos.

Era este também o primeiro mestrado em Ciências Musicais, em Portugal, seguindo-se-lhe, algum tempo depois, a legalização do doutoramento, evidentemente também o primeiro na especialidade.

Faltava ainda, porém, a licenciatura, mais difícil de obter em consequência dos encargos financeiros que acarretava.

Uma troca de impressões sobre este assunto com a jurista da Faculdade de Letras da Universidade de Coimbra, Dr.a Silvia Serem, abriu-me como que uma janela. E se se ligassem, numa única licenciatura em artes, as três formas de arte que naquela faculdade dessa licenciatura careciam: música, teatro, cinema? Estava aberto o caminho; só faltava trabalhar.

Começaram a dar-se, desde logo, os primeiros passos, mas só no início dos segundos Conselhos Científico e Directivo seguintes foi possível imprimir--lhes o necessário impulso.

Em reuniões consecutivas, nas quais tomaram sempre parte activa professores integrados nestes três ramos de arte, reuniões superiormente orientadas por um presidente excepcional do Conselho Científico - o Prof. Doutor Souza Ribeiro -, avançou-se ao ponto de a licenciatura em questão poder abrir em Outubro de 2002, como "Licenciatura em Estudos Artísticos". 
Dos cerca de 300 candidatos que então se inscreveram, foram seleccionados apenas 20, uma vez que, por um lado, se pretendia evitar uma proliferação de licenciados na matéria, sem colocação e, por outro lado, se entendia dever apostar na qualidade.

Simultaneamente, durante um ano lectivo, dirigi uma aula de História da Música integrada na Licenciatura em História, na Universidade Autónoma (1989-1990), Universidade da qual me transferi a seguir para a Universidade Lusíada onde, durante vários anos e até que a saúde mo permitiu (Março de 1991 a fins de 2001) tive a meu cargo a cadeira de História da Música de idêntica Licenciatura e orientei vários seminários em Cultura do Património, tendo por tema uma interligação da música com a arte plástica, no séc. 19/20, um dos quais na Universidade Lusíada, do Porto.

Razões graves de saúde, que me levaram a mais de um internamento de urgência no Hospital de Santa Maria (fins de 2001), não me permitiram colaborar, até ao fim, na composição desta licenciatura de combinação; mas eu tinha tido o cuidado de, muito tempo atrás, ter começado a preparar a futura continuação do projecto em curso, sem que se sentisse a falta da minha presença. E assim tem vindo a acontecer nos três escalões universitários das Ciências Musicais: licenciatura, mestrado e doutoramento, hoje radicados já na Universidade de Coimbra, e também na Universidade Nova de Lisboa.

Ao internamento inicial no Hospital de Santa Maria em 2001, outros de duração moderada se têm vindo a suceder, em alternância com a Casa de Saúde \& Repouso da Amoreira, na Ramada, onde acabei por ver a necessidade de definitivamente fixar residência: 2002.

Impunha-se portanto a necessidade de me desligar da minha anterior habitação, que guardava uma importante reserva de material de trabalho e cultura, recolhida no decurso de muitos anos de actividade: uma biblioteca vasta de alguns milhares de livros (c. de 8000), biblioteca bastante diversificada porque constituída ao longo de exigências pedagógicas e outras, sem contar as ofertas de centros de investigação e cultura, como Arquivo e Biblioteca Geral da Universidade de Coimbra, Academia Portuguesa de História, Fundação Calouste Gulbenkian, e outras; bem seleccionada música gravada em discos e CDs; numerosa documentação de arquivo em microfilmes e fotocópias, além de um número avultado de tratados de Teoria Musical e de 
música prática quinhentista nas respectivas edições originais, fotocópias estas, recolhidas na sua maior parte na biblioteca do Instituto de Música da Universidade de Colónia, com vista a estudos de análise de obras de música quinhentista e ao ensino da paleografia musical ocidental, vocal e instrumental, quando eu regressasse definitivamente a Portugal.

A este conjunto de materiais de trabalho, como apoio e como ponto de partida, há que acrescentar um piano de concerto Bechstein de 3/4 de cauda, em perfeito estado de conservação porque sempre muito bem cuidado.

A ideia, que eu de há muito nutria, de um dia vir a doar todo este material de trabalho a uma instituição de ensino superior que dela pudesse vir a fazer uso adequado, ideia que várias vezes, havia muitos anos também, tinha vindo a ser examinada com o actual director da Biblioteca Geral da Universidade de Coimbra, exame, mais de uma vez feito in loco, concretizou-se aquando da minha fixação na residência actual.

Saúde e idade aconselharam-me agora a pôr ponto final no exercício da minha profissão, mas não ainda na realização de trabalhos com ela relacionados.

Assim me seja facilitada a sua realização.

Nota - Este documento remonta ao ano de 2003 («Em jeito de introdução» apresenta a data de Julho de 2003) e foi escrito no Lar «Casa de Saúde e Repouso da Amoreira", a instância de pessoas amigas, tendo sido ditado à funcionária do mesmo Lar, Sónia de Carvalho, de quem nos chegou fielmente o texto. Contendo embora algumas imprecisões e omissões (como a do seu contributo na Universidade de Lisboa, de 1990 a 1995), optou-se por manter a totalidade deste original, válido como testemunho directo de uma vida. (J. M. P. C.) 
Maria Augusta Barbosa

\section{DEBAIXO DO FOGO: \\ A MÚSICA EM TEMPO DE GUERRA ${ }^{2}$}

O início da 2. ${ }^{a}$ Grande Guerra em Setembro de 1939 levou-me a pensar ser prudente voltar a Portugal e aguardar aqui o seu primeiro desenrolar.

Em Novembro desse mesmo ano, porém, regressei a Berlim e facilmente me adaptei a um estudo absorvente no início de uma guerra ainda relativamente calma, evidente apenas no racionamento inteligentemente elaborado e obrigatoriamente seguido, além de alguns bombardeamentos nocturnos, durante os quais os estrangeiros, ao contrário dos nacionais, não eram obrigados a recolher aos abrigos.

Aproveitei portanto essas vigílias forçadas para avançar no estudo das novas matérias e preparar os trabalhos marcados, entre os quais as longas transcrições de paleografia musical.

As aulas seguiam sempre com absoluta regularidade, mesmo após noites de um bombardeamento que se prolongava até quase de manhã.

Quando estabelecimentos de géneros alimentícios haviam sido atingidos pelos bombardeamentos dessa noite, a rádio indicava muito cedo, na manhã seguinte, quais os estabelecimentos congéneres próximos em que deviam ir fornecer-se os cidadãos que estavam inscritos nos estabelecimentos danificados.

De resto, a vida seguia normalmente, fiel às suas habituais realizações artísticas e culturais, expressas em concertos, óperas, conferências e representações teatrais.

\footnotetext{
2 Final de um auto-retrato, pelos vistos incompleto, ditado no remanso da Casa de Saúde e Repouso da Amoreira, (Ramada-Odivelas) à fiel "secretária" Sónia de Carvalho. Título nosso.
} 
Era porém indispensável a maior prudência em conversas ou simples trocas de impressões. Uma palavra menos cautelosa, uma insignificante apreciação pessoal de desacordo poderia levar à cadeia, se fosse considerada pela Gestapo adversa à doutrina política em vigor.

A espionagem podia estar em toda a parte, mesmo entre as camadas dos estudantes, que podiam nem sempre o ser. E não se sabia nunca se as críticas que alguns ousavam fazer sobre a situação sócio-política do momento eram sinceras ou se eram uma forma de anzol superiormente orientado.

A perseguição religiosa - católica ou protestante - era um facto habitualmente camuflado; e digo camuflado, porque estas duas correntes de fé eram forças demasiadamente poderosas na Alemanha, contra as quais a autoridade não ousava investir claramente; mas fazia-o em surdina.

$\mathrm{E}$ assim nasceu, nesse tempo de guerra, a missa vespertina ao entardecer de sábado, com validade de missa dominical.

Eu própria li, nessa manhã dum domingo de Inverno, de cuja data exacta me não recordo, o aviso afixado à porta da igreja fechada, no qual a autoridade eclesiástica local transmitia, à comunidade católica, a ordem recebida do governo alemão que proibia a celebração da missa antes das onze horas, sempre que um bombardeamento inimigo se tivesse prolongado para além das 24 horas de sábado; a seguir, no mesmo aviso, vinha também a notícia da concessão pontifícia da validade dominical da missa vespertina acima referida.

Estava solucionado o problema que havia sido posto ao católico praticante alemão: ou faltar à missa dominical não cumprindo o seu dever de católico ou renunciar à necessidade legítima de usar do único dia mensal de folga concedido neste tempo de guerra a todo o trabalhador alemão, para escassas horas de um passeio ao ar livre. E não se esqueça que se estava no Inverno, em que em grande parte da Alemanha o sol se põe pelas 15 horas.

Afastar os fiéis da prática religiosa era afastá-los suavemente da acção da igreja. E a igreja, tendo disso a percepção, deu a resposta adequada acatando a ordem.

Problema dominante na Alemanha de Hitler, mesmo já antes da guerra, era a comunidade judaica.

O ódio ao judeu tinha raízes fundas, reforçadas pela política nacional-socialista hitleriana, no seu objectivo de consolidar, projectar a nação alemã 
e, nela, de elevar económica e culturalmente o nível da grande massa popular. Abriam-se assim, à "Força pela Alegria", as grandes salas de óperas, teatros, bailados e concertos, organizavam-se excursões culturais ou de simples lazer, dedicavam-se-lhe conferências acessíveis mas de nível.

O judeu, com a sua tendência inteligentemente organizadora, detinha na Alemanha, aquando da subida ao poder de Hitler, fortes polos de medicina, de direito, de arte e sobretudo do alto comércio. A colaborar nas suas fileiras ele atraía de preferência os seus correligionários, ficando em princípio para segundo plano os alemães de raça ariana, por vezes forçados, por necessidade de sobrevivência, a ocupar, com preparação técnica idêntica, lugares subalternos em instituições dominadas por judeus alemães.

E o ódio nasceu. Um dia, no Outono de 1938, vi serem destruídas, à pedrada, montras de lojas de luxo, que soube depois serem propriedade de comerciantes judeus. O povo assistia com calma.

No dia seguinte, era a vez das sinagogas, incendiadas de norte a sul do país. Vi em chamas a mais importante sinagoga de Berlim. Algum tempo depois, a autoridade comunicava pela rádio que as destruições e incêndios haviam sido expressão espontânea do povo alemão. Claro, ninguém acreditou.

A perseguição violenta aos judeus, na sua dupla forma de escravatura no trabalho imposto e de tortura conducente à morte, era conhecida do povo alemão, embora nem sempre na horrível violência das suas modalidades; mas ele nada, absolutamente nada, podia fazer. E todavia alemães houve - soube-o confidencialmente - que haviam ajudado judeus, com risco muito sério da própria liberdade e vida.

De um professor universitário soube eu, mais tarde, ter conservado escondido em sua casa, até ao fim da guerra, com perigo de vida para si e toda a família, o filho de um amigo judeu.

A dona e vendedeira de um pequeno lugar de legumes e fruta disse-me em segredo esconder por hábito alguma fruta e legumes até pelas 18 horas, para que os pudessem adquirir amigos seus judeus, proibidos que estavam de fazer compras antes dessa hora; e a essa hora, tudo estaria já esgotado.

Têm-se vindo a fazer críticas cerradas ao Papa por não ter levantado a voz então perante os crimes cometidos. Mas podia e devia tê-lo feito? 
Em face do fanatismo cerrado que dominava os nacional-socialistas, particularmente concentrados na Gestapo, cujo dever consistia principalmente em manter coeso o pensamento nacional em todo o país, uma palavra de desaprovação teria bastado para despoletar sobre a igreja e sobre os católicos, na Alemanha e nos países ocupados, um ódio de consequências imprevisíveis.

Nas camadas intelectuais com que convivi, eram evidentes o descontentamento e o medo do futuro, um e outro mantidos cautelosamente no silêncio. Mas nem por isso se deixava de por vezes tomar decisões altamente perigosas, apenas do conhecimento dos amigos em quem se confiava.

Também neste caso estava a Livraria Buchholz, em Berlim, que nas suas instalações e em salas habilmente camufladas, reunira e salvara da destruição iminente telas de alto valor da pintura dos séculos 19 e 20, com os quais me foi possível dar um passo mais na apreciação da arte nesse tempo contemporânea.

Neste ambiente vivi, estudei e concluí uma licenciatura, com uma alimentação reduzida é certo, mas suficientemente regulada, perante um aumento crescente de bombardeamentos em intensidade e duração, que se estendiam agora às horas do dia como às da noite.

Em 13 de Agosto de 1943, pude regressar a Lisboa no último comboio que passou em Nürberg umas duas ou três horas antes de a cidade ter sido completamente destruída. 
Klaus Wolfgang Niemöller

Musikwissenschaftliches Institut - Universität zu Köln

\section{VON DER MUSIKALISCHEN FARBE. DER DISKURS ÜBER CHROMA UND COLOR IN MITTELALTER UND RENAISSANCE}

Seit der Antike bis zur Gegenwart wird eine Verbindung zwischen Musik und Farbe thematisiert. Dies geschieht unter vielfältigen Aspekten und keineswegs nur durch Musiker oder Musiktheoretiker. Während im 20. Jahrhundert die Bildende Kunst durch die Klangkunst inspiriert wurde, gingen umgekehrt in die Musik farbliche Vorstellungen von der „Tonmalerei“ bis zur „Klangfarbe“ ein. Die gegenseitigen metaphorischen Anleihen selbst im gegenwärtigen Sprachgebrauch reichen vom „schwarzen“ Bass und dem „Koloratur“-Sopran bis zum „Farbton“. Die Bereiche, in denen diese Konstellation diskutiert wurden und werden, reichen von der Naturwissenschaft bis zur Psychologie, von der Synästhesie bis zur Klangtechnik. ${ }^{3}$ Nachdem schon seit Carl Maria von Webers Freischütz und dann durch Hector Berlioz, Richard Wagner und Richard Strauss die Orchesterfarben in der Instrumentation als spezielle Klang- und Ausdrucksmittel entwickelt worden waren, erlangten im Expressionismus die synästhetischen Vorstellungen von Musik und Farbe einen Höhepunkt. ${ }^{4}$ Ein Meilenstein war Alexander Skrjabins symphonische Dichtung Prometheus. Le poème du feu, die 1911 in Moskau uraufgeführt wurde. Die Partitur sah neben dem Soloklavier ein „clavier à lumière“ vor, durch das die wechselnden Klangzentren des Quartenakkordes mit ihrem jeweiligen Farbenhintergrund auf eine Leinwand projeziert werden sollten. Angeregt worden war Skrjabin, der Farben mit ganz

3 K. Maurer (Hrsg.) 1985; H. de la Motte Haber (Hrsg.) 1996; M. Brzoska und E. Schmierer (Hrsg.) 1996.

4 B. Kienscherf 1996; J. Jewanski u. N. Stiller (Hrsg.) 2006. 
konkreten musikalischen Elementen verband, durch die Erfindung einer Farben-Orgel (colour organ) des englischen Kunstprofessors Wallace Rimingnton. Erst 1915 kam es in New York zu einer Realisierung der Farblichtprojektion. Arnold Schönberg - selbst expressionistischer Maler - hatte bereits 1908 dem II. Stück seiner Fünf Orchesterstücke op.16 die Überschrift Farben gegeben, eingelöst durch wechselnde Instrumentengruppen für die chromatischen Veränderungen des Grundakkordes, und 1911 dachte er in seiner Harmonielehre über die Möglichkeit einer „Klangfarbenmelodie“ nach. Gleichzeitig arbeitete er an dem Einakter Die glückliche Hand, in dem er parallel zu Wassily Kandinskys „Bühnenkomposition Der gelbe Klang systematisch Farbwirkungen von Bühne, Kostümen und Licht genau festlegte. Höhepunkt ist die Farbensymphonie zu der pantomimischen Darstellung, wie der Mann visionär die Hingabe des Weibes an den Herrn erlebt, zu der in einer Lichtpartitur die Farbveränderungen genau notiert sind. Das Faszinierende solcher Ideen durchdringt auch die Kompositionen von Olivier Messiaen und Karlheinz Stockhausen. Während sich in Messiaens Couleurs de la cité celeste die Orchesterfarben gemäss den Farbwandlungen entwickeln („les complexes de sons et timbres, évoluent à la facon des couleurs"), hat Stockhausen in seiner Oper Dienstag aus Licht für die Schlussszene elektronische Klänge auf Synthesizer, Sampler und Computer vorgesehen, mit denen die in der Partitur aufgelisteten 131 Klanfarben produziert werden.

Innerhalb der sehr unterschiedlichen Aspekte, die im Laufe der Jahrhunderte zu der Parallelisierung von Musik und Farbe führten, kommt der berühmten und aussergewöhnlichen Disputation zwischen Vincente Lusitano und Nicola Vicentino in Rom 1551 um die Chromatik besondere Bedeutung zu, und zwar einerseits durch den renaissancehaften Rückgriff auf die antike Musiktheorie, andererseits durch die zukunftsträchtige Anwendung auf eine konkrete Komposition. Anlass, Umstände und Inhalte der Disputation sind nach Henry William Kaufmanns Monographie über Nicola Vicentino (1966) umfassend von Maria Augusta Alves Barbosa in ihrer Kölner Dissertation von 1970 über Vincentius Lusitanus dargelegt worden. Um die in diesem Beitrag herauszuarbeitenden übergreifenden Perspektiven zu formulieren, genügt daher zunächst eine komprimierte Zusammenfassung als Basis.5 Ausgangspunkt

\footnotetext{
5 H. W. Kaufmann 1966; M. A. A. Barbosa 1970, besonders S. 196f. u. 236 f.
} 
war die Aufführung eines Regina caeli in einer privaten Akademie, dessen tonale Disposition Lusitano nach der Darstellung Vicentinos in seinem Traktat L'antica musica ridotta alla moderna practica 1555 als rein diatonisch beurteilte, während Vicentino behauptete, in der Musik der Gegenwart seien das chromatische und enharmonische Tongeschlecht mit dem diatonischen vermischt. Nach mehreren Diskussionsrunden sind die schriftlichen Stellungnahmen entscheidend, die beide Kontrahenten an den zum Schiedsrichter bestellten Ghiselin Danckerts sandten, als dieser zeitweilig abwesend war. Lusitano beruft sich nun auf die Unterscheidung der drei antiken Tongeschlechter (genera) und die jeweilige Intervallkonstellation innerhalb des Tetrachords auf Boethius' De institutione musica ${ }^{6}$, den er wörtlich zitiert. Damit beruft er sich nicht nur auf eine musiktheoretische Autorität, die das ganze lateinische Mittelalter herrschte, sondern auch den Autor, der ihr die antike Musiktheorie vermittelte. Dazu gehört auch die hier relevante Lehre von den drei Tongeschlechtern, die auf der pythagoräischen Methode beruht, die Intervalle durch Zahlenverhältnisse zu definieren. ${ }^{7}$ Boethius übersetzt in dem von Lusitano herangezogenen Zitat das zugrunde liegende griechische Wort chroma (Farbe) ins lateinische color und erläutert gleichzeitig, was dies in der Musik meint und aus welcher Vorstellung heraus die Vokabel „Farbe“ auf musikalische Phänomene übertragen wurde:

\begin{abstract}
Chroma autem quod dicitur color quasi iam ab huiusmodi intentione prima [tetrachordum diatonicum], mutatio. Cantaturper Semitonium et semitonium et tria Semitonia: tota enim Diatesseron consonantia et duorum tonorum ac semitonij, sed non pleni. Tractum est autem hoc vocabulum ut diceretur chroma a superficiebus que cum permutantur, in alium transeunt colorem.
\end{abstract}

Chroma aber, das color genannt wird, [ist] jetzt gleichsam eine Veränderung von der eben bestimmten ersten Anordnung [der des diatonischen Tetrachords]. Es wird gesungen durch Halbton und Halbton und drei Halbtöne: die gesamte Konsonanz der Quarte besteht deshalb aus zwei Ganztönen und einem Halbton, jedoch einem unvollkommenen. Hergeleitet ist aber die Vokabel chroma wie gesagt wird von Oberflächen, die, wenn sie verändert werden, in eine andere Farbe übergehen.

Im letzten Satz wird auf die Herkunft der doch eigentlich erstaunlichen Parallelisierung von Musik und Farbe, hingewiesen, die bis in die Antike zurückreicht. ${ }^{8}$ Chroma ist auf Musikalisches bezogen zwar nur eine Metapher,

\footnotetext{
6 Boethius 1966, S. 318.

7 B. Münxelhaus 1976

8 E. Roch 2010
} 
jedoch nimmt sie schon sehr früh Bezug auf die Wahrnehmung und die die psychische Wirkung der Musik, denn das griechische chroma bezog sich ethymologisch - primär auf die Hautfarbe. Die Veränderung der Hautfarbe durch Krankheit oder Emotionen wie Angst oder Zorn verband sich musikalisch mit der ethischen Bewertung der drei antiken Tongeschlechter. Etwa seit 400 v. Chr. wurden die Melodiegattungen des Diatonischen, des Chromatischen und des Enharmonischen unterschieden und dann auch ethischen Kriterien unterzogen, z. B. durch Plato. Das Chromatische mit seinen Halbtönen galt als symptomatisch für einen weichen, schwachen, unmännlichen Charakter, und damit geradezu als „ungriechsich“. Eine chromatisch geprägte Verzierungspraxis von Spielern der Kithara, die dazu die Zahl der Saiten erhöhten, wurde als unangemessen etwa für den musikalischen Vortrag der alten Mythen erachtet. Als männlich galt der dorische Melodie-Dialekt. Die den Intervallbestimmungen in der Skala des Tonsystems zugrundeliegenden Zahlenverhältnisse bestimmten also auch die Bewertung der darauf basierenden Musik. Von daher wird auch verständlich, dass bereits Aristoteles in seiner Schrift De sensu et sensibili von der Idee geleitet wurde, Farbzusammenstellungen auf dieselben einfachen Zahlenproportionen zurück zu führen wie musikalische Intervalle.

Mit dem Zitat von Boethius schliesst Lusitano die sich daran anschliessende musiktheoretische Tradierung der Begriffsfelder chroma und color ein. Dazu gehört auch das im Streit von Lusitano mit Vicentino angesprochene Grundproblem: das Verhältnis zwischen zahlenhaft-systematischer Ordnung von Musik in durch Proportionen bestimmbaren Intervallen und dem sinnlich wahrnehmbaren Klangeindruck, zwischen ratio, verankert in den Zahlenwissenschaften des Quadriviums, und sensus. In den mittelalterlichen Schriften zur Musiktheorie werden daher die beiden Termini auf verschiedene Bedeutungszusammenhänge bezogen, ${ }^{10}$ die zwischen „Chromatik“ und den tatsächlichen „Farben“ in der musikalischen Notation angesiedelt sind. Bemerkenswert ist, wie Guido von Arezzo um 1025 in seinem richtungweisenden Micrologus die Farbvorstellung auf die Kirchentonarten überträgt, die den Kirchengesängen der Gregorianik auf wundersame Weise die Erscheinung einer Farbe (coloris

\footnotetext{
9 F. Hentschel 2000.

10 Lexicon 2001, 5. Faszikel, Sp. 484-495 und 550-556.
} 
facies) zu verleihen schienen. ${ }^{11}$ Bereits 1480 hatte der italienische Musiktheoretiker Gaffurio in seinem gedruckten Theoricum opus musice discipline mit einem Kapitel „De tribus tetrachordum generibus“ (lib.V, cap. 2) die antike Lehre von den antiken Tongeschlechtern wieder aufgegriffen. ${ }^{12}$

Zunächst aber erscheint der Begriff „color“ in musikalischem Zusammenhang ganz konkret in der Notation. Die Färbung einer oder zwei Notenlinien (F-Linie: rot) in der Guidonischen Notation diente zur Anzeige einer bestimmten Tonhöhe in den gregorianischen Gesängen, ehe diese Aufgabe die Schlüssel übernahmen. Neben der Tonhöhe diente die Färbung in der Polyphonie auch zur Veränderung der rhythmischen Zeitstruktur in den Mensuren. Seit der Ars nova wurden die normalen schwarzen Noten zur Anzeige eines Mensurwechsels rot gefärbt. ${ }^{13}$ Insofern gilt auch hier die Bestimmung von color durch Boethius als mutatio. Der Begriff color nahm aber in der musikalischen Zeitstruktur der Hauptgattung der Ars nova, der isorhythmischen Motette, noch eine weitere, formbildende Bedeutung an: color als Wiederholung desselben Melodieabschnittes des cantus firmus im Tenor der Motette. Während Johannes de Muris in seinem Kapitel „De colore“ durchaus die Unterscheidung zwischen Wiederholung der Tonfolge (voces) und Wiederholung der rhythmischen Notenwerte (figurae) als talea unterscheidet, ${ }^{14}$ differenziert Johannes de Beldemandis in seinem längeren Kapitel „De colore et talea“, dass die Wiederholung von Tonfolge und Notenwerten nicht zugleich erfolgen können. ${ }^{15}$ Offensichtlich wird hier eine erweiterte Bedeutung von color herangezogen, als Färbung im Sinne von Ausschmücken. So formuliert dann Johannes de Garlandia: „Color ist die Schönheit des Klanges bzw. das Objekt beim Hören, wodurch das Gehör das Angenehme aufnimmt“, hervorgerufen

\footnotetext{
11 ...ut mirum in modum quandam ab ea coloris faciem ducere videantur. Micrologus 1955, S. 11

12 F. Remp 1989

13 W. Apel 1962, S. 134.

14 J. de Muris 58: Color in musica vocatur similitude figurarum unius processus pluries repetita positio in eodem cantus. Pro quo notandum quod nonnulli cantores ponunt diversitatem inter colorem et taleam. Nam vocant colorem, quando repetuntur eae voces; taleam vero quando repetuntur similes figurae.

15 P. de Beldemandis CS III, 226: vult namque ista [modernorum] opinion quod differentia sit inter colorem et taleam [...] assignando, quod in colore fiat repetitio similium vocum [...] et quod in talea fiat repetitio solum similium figurarum.
} 
durch eine formelhafte melodische Motivik, oder durch die Anreicherung des Klanges durch Mehrstimmigkeit wie im Conductus, oder durch melodische Wiederholungen wie in Rondelli und Volksgesängen. ${ }^{16}$ Johannes de Garlandia erlaubt die Beimischung von Dissonanzen nicht nur gemäss dem Kriterium der Schönheit (propter pulchritudinem), sondern auch „um des ,Schmucks' (propter colorem) willen. ${ }^{\text {"17 }}$ Die Beimischung von Dissonanzen wird sogar im wörtlichen Sinne „Farbe genannt“ und zwar im direkten Vergleich mit dem Maler, der den einfachen Farben unzählige sanfte Farbarten beimischt. ${ }^{18}$

Wesentlicher als der Vergleich mit der Malerei und ihren verschiednen Farben ist die Übernahme der Terminologie aus der Sprachdisziplin der Rhetorik, der color rbetoricus, wie Marchettus von Padua explizit formuliert, indem er speziell auf ihre Sinnfiguren verweist. ${ }^{19}$ Nach Cicero, der von einer durch Farben gemalten Rede spricht (coloribus picta ... oratio), werden in der mittelalterlichen Rhetorik zahlreiche Stilfiguren als Ausschmückungen (exornationes) aufgelistet, darunter „Wiederholungen“ (repetitiones) als Wortfigur. ${ }^{20}$ Damit kommen für die Musik gleich zwei Wesensseiten von color ins Blickfeld, das „Ausschmücken“ und die rhetorische Wirkungsabsicht. Diese affektive Wirkungsabsicht über Farbe in der Musik konkretisierte sich z.B. in Form von sogenannter „Augenmusik“ in der Schwärzung von an sich weissen Noten zum Zeichen der Trauer. So ist die berühmte Trauermusik von Josquin für seinen Lehrer (1495) Déploration sur la mort de Johannes Ockeghem mit dem Introitus der Totenmesse im Tenor symbolhaft nur in schwarzen Noten notiert. Das gewählte Notierungssystem hat ausserdem zur Folge, dass die Musik angemessen langsam und getragen ist. Ausschmücken, Verzieren ist bereits für die Vokalmusik als Umspielen einer Kernmelodik, als „Kolorierung“ musikgeschichtlich diskutiert worden, noch deutlicher wird das colorare aber in der Instrumentalmusik. Der Konstanzer Organist Hans

16 J. de Garlandia 1972, S. 95: Color est pulchritudo soni vel obiectum auditus, per quod auditus sucipit placventiam. Et fit multis modis: aut sono ordinate, aut in florificatione soni, aut in repetitione ejusdem vocis vel diverse.

17 Hentschel (wie Anmerkung 7), S. 181-184.

18 Sed et pictor naturales colores artificio transferens, innumera coloris genera placabilia simplicibus commiscet.

19 M. de Padua 1961, S. 71: in musica fiunt interdum colores ad pulchritudinem consonantiarum, sicut in grammatica fiunt colores rhetorici ad pulchritudinem sententiarum.

20 F. Quadlbauer 2003, Sp. 61f. 
Buchner hat bereits um 1530 in seinem Lehrbuch der Orgelkunst (fundamentum) gezeigt, wie die Choralmelodie des Te Deum laudamus nicht nur zu einem einfachen dreistimmigen Orgelsatz verwandelt wird, sondern auch in einem dritten Notenbeispiel, wie die Organisten jede Stimme mit ihren Kolorierungen versehen (organistae addunt cuique voci suos colores). ${ }^{21}$ So wurden wegen der gehäuften Verzierungen die deutschen Orgelkomponisten ab 1570 wohl auch zu einer Gruppe der „Koloristen“ zusammengefasst. ${ }^{22}$ In den Tabulaturbüchern von Elias Nicolaus Amerbach (1571) und Jacob Paix (1583) gehörte es zum Wesen der Intavolierung, dass sie „mit Fleiss coloriret“.

Die Einrichtung der Claviatur bei den Tasteninstrumenten mit schwarzen Obertasten für Halbtöne führt zu einer Auffassung von Chromatik“, die zu dem Disput Lusitano Vicentino zurückführt, ja bis zu Boethius. Sebastian Virdung hat 1511 in seiner Musica getutscht, der für Instrumentisten eingedeutschten lateinischen Musiklehre, im Dialog mit seinem Schüler darauf hingewiesen, dass nach Guido von Arezzo einige kamen, „die haben das [System mit 20 diatonischen Tonstufen] noch subtiler gemacht / und Boetium auch gelesen und nach dem andern geschlecht Cromaticum genant//das moncordum aufgeteilet." ${ }^{23}$ Bei der Frage, was denn das chromaticum genus sei, übersetzt Virdung nicht nur die Definition einer „Färbung“ von Boethius, sondern weist auch auf die zwei erweiterten Aspekte hin: die musikalische Verzierung und die chromatisch erweitertet Claviatur des Tasteninstruments, im Wortlaut: „Croma ist eben so vil gesagt als eyn farb / vnnd Cromaticum eben als eyn geferbt sind / Das heist man auch sunst zuzeiten etwas aussgestrichens oder ein wol geziertes ding / Also ist auch hie dye kunst Musica und das instrument noch vil subtiler aussgestrichen / vnd bas geziert /durch die semitonia des geschlechtes Cromaticum genent.“ Im diatonischen Tongeschlecht ergeben sich durch die Quarten mit zwei Ganztönen und einem kleinen Halbton 20 Tonstufen, „Stimmen“ (voces) oder „schlüssel“ (claves); dazu kommt die Dopppelstufe „bfahmi“. Die abgebildete Claviatur zählt so 22 Tasten (darunter zwei schwarze). In Analogie zu der chromatischen Doppelstufe bfahmi werden nun nach Virdung weitere 13 Halbtöne („myndere semitonia“)

\footnotetext{
21 H. Buchner 1974, S. $22 \mathrm{f}$.

22 A. Edler 1997, 27.

23 S. Virdung 1970, Bl. Eiij verso s.
} 
hinzugenommen, so dass sich „yetz gemainlich [aus] baider geschlecht“ für das Gesamtsystem über drei Oktaven 38 „schlüssel“ (claves) und damit 38 Tasten ergeben, die in einer zweiten Abbildung dargestellt bereits die moderne Tastatur aufweisen. Die weitere Entwicklung der Clavierinstrumente und ihrer Stimmungen führt wieder zu den zwischen Lusitano und Vicentino strittigen Grundfragen von chroma und color zurück. ${ }^{24}$

$\mathrm{Zu}$ Virdungs Zeit wurden also bereits dem achtstufigen Tonsystem chromatische Zwischentöne hinzugefügt, zunächst mit cis und es, fis und as. Dies zeigt das Diagramm des praktischen Tonsystems mit den Hexachorden der Solmisation, das von Johannes Cochlaeus 1512 in seinem Tetrachordum musices unter der Überschrift Diatonicum Guidonis introductorium abgebildet ist. In der scala ficta wird so schliesslich jedem Tonbuchstaben entweder ein b rotundum oder h quadratum hinzugefügt, ${ }^{25}$ wie bereits Andreas Ornitoparch 1517 schrieb. ${ }^{26}$ Er weist aber auch auf den Begriff hin, der verdeutlicht, dass die chromatischen Töne in der musica ficta keine selbständigen Tonstufen im diatonischen System darstellen, sondern als coniunctae nur eine improvisierte Veränderung von Ganzton in Halbton oder umgekehrt darstellen. ${ }^{27}$ Bereits im Traktat des Johannes Hollandrinus und seinen Tradierungen im 15. Jahrhundert wird den „coniunctae“ ein eigenes Kapitel gewidmet. Der systematische Nachweis von Halbtönen ausserhalb der Guidonischen Skala in den Gregorianischen Gesängen und die Bezeichnung als „coniunctae“ ist eine Besonderheit dieser Lehrtradition. ${ }^{28}$ Die Erniedrigung durch b-fa oder Erhöhung durch h-mi ist also mit der eigentlichen Tonstufe „verbunden“. Praktiziert wird sie sowohl durch die Singstimme wie auf dem Instrument (quod coniuncta secundum vocem hominis vel instrumenti est facere...). Ausdrücklich hebt Hollandrinus hervor, dass dies nicht als eine Veränderung (mutatio) eines Halbtones in einen Ganzton und umgekehrt zu verstehen ist, sondern dass nur an dem Tonort, an dem ein Ganzton bzw. Halbton zu sein

24 F. J. Ratte 1991.

25 H. von Loesch, 2003, S. 134, Abb. 3 u. S. 161-166.

26 A. Ornitoparch 1977, fol. Cv verso: Musica ficta fingit in quacunque clave quamcunque vocem.

${ }^{27}$ Est autem coniuncta, canere vocem in clave, que non est in ea. Uel est toni in semitonium aut semitonij in tonem subita et improuisa mutatio. (Ebenda).

28 Traditio 2010, Bd. I, S. 140 f. 
pflegt, ein anderer gesungen oder gespielt wird. ${ }^{29}$ Damit bezieht er sich auf Johannes de Muris, der eine Veränderung ausserhalb des regulären Systems der musica plana als irregulär erachtete (Vocatur autem irregularis mutatio falsa mutatio), jedoch nicht in der musica mensurabilis, weshalb bei einigen Instrumenten wie den Orgeln überall der Ganzton geteilt wird, um Konsonanzen im Zusammenklang herzustellen. ${ }^{30}$

Indem Franciscus Gafurius die halbtönigen Teilungen der Tonstufen als Fictas autem seu coloratas contrapuncti species, also die musica ficta nicht als musica falsa begreift, sondern als eine „Einfärbung“, verweist er darauf, dass diese „im Rahmen einer chromatischen Ausmessung ,kolorierte’ Gesänge zeigen, die auch als ficta bezeichnet werden (hae enim, quod cromatica dimensione ducuntur, coloratas demonstrant cantilenas, quas et fictas dicunt).

Nachdem bereits Gioseffo Zarlino sich 1548 ein chromatisches Clavicembalo hatte bauen lassen, präsentierte Vicentino in seiner Schrift L'antica musica 1555 sozusagen als Rechtfertigung für seine gegen Lusitano erlittene Niederlage sein enharmonisches Archicembalo. ${ }^{31}$ Im Anschluss an diese Instrumente konnte auch die Vision einer engen Verbindung von Farbe und Musik um 1590 durch die Konstruktion eines entsprechenden Instrumentes praktisch umgesetzt werden. Der Mailänder Maler Giuseppe Arcimboldo, Hofmaler von Kaiser Rudolf II. in Prag, noch heute berühmt durch seine Porträts aus Blumen und Früchten, war wohl der erste, der die Korrespondenz von Farben und Tönen auf einem chromatischen „gravicembalo“ darstellen liess. Der kaiserliche Musiker Mauro Cremonense sollte Arcimboldis „colori sopra una carta“ als Klänge auf dem Instrument darstellen. ${ }^{32}$ Vicentinus Gravicembalo, das sich am Hofe der d'Este in Ferrara befand, war dann wohl auch Anregung für die kühnen chromatischen Kompositionen von Carlo Gesualdo, der sich nach seiner Heirat mit Eleonore d'Este seit 1594 zwei Jahre

\footnotetext{
29 Ebenda Bd. II (2010, Bd.20), S.221 u. Bd. III (2011, Bd.21), S.77: Sequitur de naturis coniunctarum: Et non est intelligendum, quod tonus mutetur in semitonium, sed in loco in quo solebat esse tonus per coniunctam fit semitonium e econverso.

30 J. de Muris II, S.294: Ille igitur etsi dicantur falsa, quantum ad planam musicam, non tamen quantum ad musicam mensurabilem. Ideo in aliquibus instrumentis, ut in organis quasi ubique tonus dividitur in duo semitonia inaequalia, ut plures ibi fieri possunt concordie.

31 Ratte (wie Anm. 22), S. 385 - 396.

32 P. Preiss 1972, S. 163ff.
} 
in Ferrara aufhielt. Ein Madrigal wie „Moro lasso“ setzte mit der Chromatik zu diesem Beginn die neue ästhetische Richtung der affektiven Nachahmung der Textinhalte um. Sie hatte u.a. Vicentino gefordert, denn die Musik sei zu nichts anderem gemacht, „per esprimere il concetto, et le passioni et gli effetti di quelle“, wobei die die Intervalle der drei antiken Tongeschlechter „secondo il sogetto della parole" affektiv zu gebrauchen sind. ${ }^{33}$

Die zunächst in langen musiktheoretischen Diskursen aufgekommenen Begriffe von Farblichkeit in der Musik, chroma und color, haben so seit der Spätrenaissance unmittelbar in Kompositionspraxis und Aufführungsweise Einzug gehalten und im Barock eine Blüte erlebt, die bei Johann Sebastian Bach kulminiert, sei es im chromatischen Quartgang der rhetorischen Figur des passus duriusculus (Kantate „Weinen, Klagen, Sorgen“), sei es instrumental in der Chromatischen Fantasie und Fuge. Nur der in Rom als Jesuit wirkende Universalgelehrte Athanasius Kircher hat 1650 in seiner Musurgia universalis die ursprüngliche konkrete Verbindung zwischen Musik und Farbe wieder aufgegriffen. In einer Tabelle hat er 13 Intervalle innerhalb der Oktave, die als „grün“ die Mitte einnimmt (VIRIDIS DIAPASON) aufgeführt und sie mit bestimmten Farben in Relation gesetzt. Mit Blick auf die vorstehenden Überlegungen, die von Lusitanos und Vicentinos Kontroverse ausgingen, bilden so nicht von ungefähr den Rahmen der Tabelle der „weisse“ Halbton (Albus Semitonium) und der „schwarze“ Ganzton (Niger Tonus maior). ${ }^{34}$

\section{Bibliographie}

Apel, Willi (1962), Die Notation der polyphonen Musik 900-1600. Leipzig.

Barbosa, Maria Augusta Alves (1977), Vincentius Lusitanus. Ein portugiesischer Komponist und Musiktheoretiker des 16. Jahrhunderts. Lissabon.

Beldemandis, Prosdocimus de: Tractatus practice de musica mensurabili, CS III, 226 Boethius (1966), De institutione musica. Ed. Nachdruck Frankfurt.

Brzoska, Matthias und Schmierer, Elisabeth (Hrsg. 1996), Töne - Farben - Formen. Über Musik und die Bildenden Künste. Laaber.

33 K. W. Niemöller 2002, s.90f.

34 A. Kircher 1970, S. 568. 
Buchner, Hans (1974), Sämtliche Orgelwerke. Erster Teil: Fundamentum, hrsg. Jost Harro Schmidt. Frankfurt 1974.

Edler, Arnfried: Gattungen der Musikfür Tasteninstrumente., Teil 1: Von den Anfängen bis 1750, Laaber 1997, 27. (Handbuch der musikalischen Gattungen 7,1).

Garlandia, Johannes de (1972), De mensurabili musica. Ed. Erich Reimers, Wiesbaden.

Guido Aretinus, Micrologus (1955), ed. Joseph Smits van Waesberghe.

Haber, Helga De la Motte (Hrsg. 1996), Musik und bildende Kunst. Von der Tonmalerei zur Klangstruktur. Laaber.

Hentschel, Frank (2000), Sinnlichkeit und Vernunft in der mittelalterlichen Musiktheorie. Stuttgart.

Jewanski, Jörg u. Stiller, Natalie (Hrsg. 2006), Farbe - Licht-Musik. Synästhesie und Farblichtmusik. Frankfurt.

Kaufmann, Henry William (1966), The Life and Works of Nicola Vicentino (1511 - c. 1570). American Institute of Musicology.

Kienscherf, Barbara (1996), Das Auge hört mit. Die Idee der Farblichtmusik und ibre Problematik - beispielhaft dargestellt an Werken von Alexander Skrjabin und Arnold Schönberg. Laaber.

Kircher, Athanasius (1970), Musurgia universalis. Rom 1650, Nachdruck Hildesheim.

Lexicon Musicum Latinum Medii Aevi. Wörterbuch der lateinischen Musikterminologie des Mittelalters bis zum Ausgang des 15. Jabrhunderts (2001) hrsg. Michael Bernhard. München.

Loesch, Heinz von (2003), „Musica - Musica practica - Musica poetica“, in: Deutsche Musiktheorie des 15. bis 17. Jahrhunderts. Darmstadt.

Maurer, Karin (Hrsg. 1985), Vom Klang der Bilder. Die Musik in der Bildenden Kunst des 20. Jahrhunderts. München.

Münxelhaus, Barbara (1976), Pythagoras musicus. Zur Rezeption der pythagoräischen Musiktheorie als quadrivialer Wissenschaft im lateinischen Mittelalter. Bonn-Bad Godesberg.

Muris, Johannes de, Libellus cantus mensurabilis, Coussemaker, Scriptores de musica (CS).

Muris, Johannes de, Speculum musicae, Gerbert, Scriptores de musica (GS) II, S.294

Niemöller, Klaus Wolfgang (2002), „Tradition und Innovation des Affekt-Denkens im Musikschrifttum des 16. Jahrhunderts" in: Tugenden und Affekt e in der Philosophie, Literatur und Kunst der Renaissance. Hrsg. Joachim Poeschke u.a., Münster.

Ornitoparch,Andreas (1977), Musicae active micrologus. Leipzig 1517, Nachdruck Hildesheim.

Padua, Marchetus de (1961), Pomerium. Ed. Joseph Vecchi.

Preiss, Pavel (1972), „Farbe und Klang in der Theorie und Praxis des Manierismus“ in Colloquium Musica Bohemica et Europea Brno 1970. Brno. 
Quadlbauer F. (2003), „Colores rhetorici“ in: Lexikon des Mittelalters III. München.

Ratte, Franz Joseph (1991), Die Temperatur der Clavierinstrumente. Quellenstudien $z u$ den theoretischen Grundlagen und praktischen Anwendungen von der Antike bis ins 17. Jahrhundert. Kassel.

Remp, Frieder (1989), „Elementar - und Satzlehre von Tinctoris bis Zarlino“ in Italienische Musiktheorie im 16. und 17. Jahrhundert. Antikenrezeption und Satzlehre. Darmstadt.

Roch, Eckhard (2010), Chroma - Color - Farbe. Urtsprung und Funktion der Farbenmetapher in der antiklen Musiktheorie. Mainz.

Traditio Iohannis Hollandrini, Hrsg. Michael Bernhard u. Elzbieta Witkowska-Zaremba, 2010. Bd. I, München.

Virdung, Sebastian (1970), Musica getutscht 1511. Faksimile-Nachdruck hrsg. Klaus Wolfgang Niemöller, Kassel. 
Pedro Carlos Lopes de Miranda

Escola Diocesana de Música Sacra de Coimbra

\section{DIEGO BUXEL \\ (? - †POST 1572) \\ EM COIMBRA}

O mestre de Capela da Catedral de Ciudad Rodrigo entre 1522 e 1572 (anos da primeira e última notícias da sua actividade) Diego Buxel - ou também Bruxel $^{35}$ - tem interesse especial para a história da polifonia renascentista de Coimbra por duas razões: por se encontrarem em Coimbra as duas únicas obras tidas até agora seguramente como de sua autoria - a intitulada Missa Bruxel e um Aleluia no MM 9 da P-Cug - e por ser seguro também que sob a sua direcção fez a formação musical como moço de coro naquela capela musical D. Francisco de Santa Maria (†1597), àquele tempo Francisco Mouro, que veio a ser mestre da Capela do bispo de Coimbra D. João Soares e cantor mor do Mosteiro de Santa Cruz. É, por sua vez, nesta sequência de mestres e discípulos que se vem a situar D. Pedro de Cristo (†1618), que se formou sem dúvida no "cantorado" de D. Francisco. Dir-se-ia, portanto, que Diego Buxel é um "avô musical" de D. Pedro de Cristo. ${ }^{36}$

Ora, o objectivo deste breve contributo é exactamente propor à curiosidade dos cultores da polifonia desta época mais um conjunto significativo de obras que considero com o mínimo de plausibilidade serem deste mestre de Ciudad

35 Opto pela forma Buxel pelo facto de ser claramente a maioritária nos documentos. Bruxel é usado apenas duas vezes, nas actas do cabido de Plasencia e no MM 9 da Biblioteca Geral da Universidade de Coimbra. Cf. Pedro Miranda 2004: 229-257.

36 A relação entre D. Francisco de $\mathrm{St}^{\mathrm{a}}$ Maria e Diego Buxel, bem como os dados biográficos de ambos e confirmação da identidade entre Buxel e o Bruxel das obras (Missa Bruxel e Aleluia) constantes do MM 9 da P-Cug (fls $77 \mathrm{v}^{\circ}$ a 87 e a fls $105 \mathrm{v}^{\circ}$ a 106, respectivamente) encontra-se na minha tese de mestrado (Pedro Miranda 2001). Os capítulos que contêm a investigação nestes pontos estão integrados no artigo referido na nota anterior. 
Rodrigo e que, à semelhança das duas já referidas no MM 9 da Biblioteca Geral da Universidade de Coimbra, se encontram em Coimbra.

Refiro-me aos 32 hinos do MM 221 da P-Cug, cujo interesse começa por ser despertado pelo facto de ter na primeira folha as anotações: Este libro he da capella do Señor Bispo...; e ainda mais simplesmente: Este livro be do Sñor bispo ou este libro he da capella. Este dado, com muitas outras informações concordes já recenseadas na investigação acima referida na nota 2 , dão consistência histórica à existência duma capela musical episcopal, distinta da capitular, de que D. Francisco de $\mathrm{St}^{\mathrm{a}}$ Maria foi mestre ao chegar a Coimbra, antes de professar no Mosteiro de $\mathrm{St}^{\mathrm{a}}$ Cruz.

A anteceder e a suceder ao corpo central - um livro de hinos, de execução muito esmerada e de mão e estilo únicos - encontram-se duas secções de textos litúrgicos vários. Por essa razão lhe foi gravado na lombada: HIMNOS/E RESP/ OOSO/RIOS. Nestas duas secções, as mãos são várias e a escrita geralmente mais cuidada na secção posterior; o restante, em que se contam também peças sem texto, é numa escrita cursiva, em alguns casos desleixada mesmo. O papel é no entanto sempre o mesmo, o que é fácil de verificar pela marca de água.

O livro de hinos primitivo e homogéneo, o que imediatamente nos interessa agora, é constituído pelos seguintes:

Conditor alme siderum (fls. $\left.9 \mathrm{v}^{\mathrm{o}}-12\right)$ : para o tempo de Advento

Christe Redemptor omnium (fls. 12v -16 ): para o tempo de Natal

Hostis Herodes (fls. $\left.16 \mathrm{v}^{\mathrm{o}}-19\right)$ : para a Epifania

Audi benigne conditor $\left(19 \mathrm{v}^{\circ}-22\right)$ : para a Quaresma

Vexilla regis $\left(22 \mathrm{v}^{\circ}-26\right)$ : para o Domingo da Paixão

Ad cenam agni (fls. $\left.26 \mathrm{v}^{\circ}-30\right)$ : para a oitava da Páscoa

Jesu nostra redemptio (fls. 30v ${ }^{\circ}-33$ ): para a Ascenção

Veni creator (fls. $33 \mathrm{v}^{\circ}-37$ ): para o Pentecostes

O lux beata Trinitas (fls. 37v $\left.\mathrm{v}^{\mathrm{o}}-39\right)$ ): para os domingos per annum

Pange língua (fls. 39v $\mathrm{v}^{\mathrm{O}}$ 42): para a festa do Corpo de Deus

Sacris solemnis (fls. $42 \mathrm{v}^{\circ}-46$ ): para a festa do Corpo de Deus

Laude Mater (fls. $46 \mathrm{v}^{\circ}$-49): para a festa da Transfiguração

Christe redemptor omnium conserva tuos famulos (fls. $49 \mathrm{v}^{\circ}-52$ ): para a festa de Todos os Santos 
Ave maris stella (fls. $52 \mathrm{v}^{\circ}-56$ ): para a Assunção

Petrus beatus (fls. $56 \mathrm{v}^{\circ}-58$ ): para a festa das Cadeias de S. Pedro

Doctor egregie Paule (fls. 58v ${ }^{\circ}-59$ ): para a festa da Conversão de S. Paulo

Ut queant laxis (fls. 59v ${ }^{\circ}$-62): para a solenidade do Nascimento de S. João Baptista

Aurea luce et decore (fls. $\left.62 \mathrm{v}^{\circ}-64\right)$ : para a solenidade de S. Pedro e S. Paulo

Nardi Maria pistici (fls. $64 \mathrm{v}^{\circ}-66$ ): para a festa de St ${ }^{\mathrm{a}}$ Maria Madalena

Quo custode procull (fls. $66 \mathrm{v}^{\circ}-73$ ): para a festa de S. Miguel Arcanjo

Exsultet coelum laudibus (fls. $67 \mathrm{v}^{\circ}-70$ ): para o comum dos Apóstolos

Deus tuorum militum (fls 70 vo-73): para o comum de um Mártir

Sanctorum meritis (fls. $73 \mathrm{v}^{\circ}-76$ ): para o comum de vários Mártires

Iste confessor Domini (fls. $76 \mathrm{v}^{\circ}-79$ ): para o comum dos Confessores

Jesu corona virginum (fls. $79 \mathrm{v}^{\circ}-82$ ): para o comum das Virgens

Urbs beata Iherusalem (fls. $82 \mathrm{v}^{\circ}-85$ ): para a dedicação de uma igreja

Te lucis ante terminum (fls $85 \mathrm{v}^{\circ}-87$ ): para os domingos per annum

Te lucis ante teminum (fls $87 \mathrm{v}^{\circ}-88$ ): para as Completas de Domingo

Tristes erant apostoli (fls. $88 \mathrm{v}^{\circ}-90$ ): para o comum dos Apóstolos

Claro paschali gaudio (fls. 90vº-94): para o comum dos Apóstolos

Deus tuorum militum (fls. 94vำ-97): para o comum de um Mártir

Vexilla regis prodeunt (fls. $97 \mathrm{v}^{\circ}-101$ ): para a festa da Exaltação da Santa Cruz ${ }^{37}$

Entretanto, nas primeiras folhas, que teriam ficado originalmente em branco conforme uso frequente, foram copiadas as seguintes peças:

fl 1 1v -2: Christus natus est nobis, Invitatório do Natal

fls. $2 v^{\circ}-3$ : pequenas peças sem texto, com todas as vozes na mesma página.

fls. 3: dois Benedicamus domino

fls. 3v-4: Responsório da liturgia dos defuntos Libera me domine...

fls. $4 \mathrm{v}^{\mathrm{o}}-5$ : fabordões sobre tons salmodicos

fls. 5vº- Benedicamus Domino: para a resposta conclusiva do Ofício.

fls. $6 \mathrm{v}^{\circ}-8$ : hino Te lucis ante terminum

fls. 8vำ- Lumen ad revelationem: texto da antífona do Nunc dimittis da hora de Completas

37 É de notar a ordem algo caótica pela qual aparecem os hinos para o Santoral, além disso intercalados com hinos para o ofício comum dos vários tipos de santos. Já quanto ao Temporal, foi respeitada uma ordem mais próxima da realidade. 
Nas últimas folhas, também originalmente em branco, em letra cuidada mas cursiva e de tinta diferente foi copiado um Ave maris stella (fls. 101vº-104).

Portanto, como se vê, olhando à totalidade das obras contidas, trata-se, de facto, de reportório exclusivamente para o Ofício, embora, tal como o códice se encontra, a indicação da lombada acima referida peque por excesso quanto aos responsórios: apenas um.

Mas, por que razão o interesse despertado por este livro de polifonia há-de residir no facto de ser da capela episcopal? Em primeiro lugar, todas as notas externas o colocam no séc. xvi. A marca de água do papel, é recenseada e definida por C-M Briquet (1907) como deux flèche en sautoir colocandoa basicamente na Itália de quinhentos, com a excepção de poder ter sido aplicada a papel fabricado em Troyes, centro norte de França, pela pouca probabilidade de importação da península itálica para tal região. De entre as assim genericamente classificadas entre os nros 6267 e 6282 não se encontra nenhuma exactamente igual à do MM 221, embora se possa dizer que as que mais características têm em comum com ela sejam os nro s 6267 e 6268 . A do MM 221 é a seguinte:

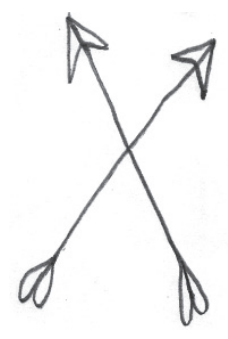

A letra é genericamente humanista redonda, bem cuidada e com nítida preocupação de estilo, a pender para um género francês bem identificado como corrente pelo séc. Xvi (Silvestre 1843: a fls. 46), com iniciais tipicamente quinhentistas também, estilizadas num geometrismo predominantemente curvo, tanto quanto me foi possível verificar claramente integrável em modelos italianos (Silvestre 1843: a fls. 1 e 56), de que é uma versão apenas mais sóbria.

Quer as iniciais, quer as minúsculas têm ainda o interesse de serem o único aspecto que este livro tem em comum com um outro da P-Cug, o MM 34, também em papel, mas com uma capa em pergaminho que ostenta, 
exactamente com o mesmo tipo de inicial e de minúscula: Livro dos defuntos. Este livro contém numa primeira e mais vasta secção, com algumas preocupações de estilo de execução, a preto e vermelho, obras para a liturgia dos defuntos de Aires Fernandes, Guerreiro, Trosilho, Bernal, Fernão Gomes [Correia] e Morales e, a partir da fl. $37 \mathrm{v}^{\circ}$ e em letra já perfeitamente cursiva, algumas rubricas para a Missa de Requiem de Francisco Mouro, isto é, D. Francisco de $\mathrm{St}^{\mathrm{a}}$ Maria antes de professar em $\mathrm{St}^{\mathrm{a}}$ Cruz de Coimbra; segue-se-lhe ainda, a fls. $40 \mathrm{v}^{\mathrm{o}}$, um Jesu redemptor, texto provavelmente litânico bastante frequente nas fontes portuguesas da época, para as exéquias, de um André Moutinho.

Que este segundo livro - o MM 34 - possa ser também da capela episcopal, sobretudo pelo facto de conter os trechos de Francisco Mouro, mas também pela presença na capa de letra exactamente igual à do MM 221 - tenha-se em conta sobretudo a inicial capital de Livro - faz com que se levante com especial acuidade a pergunta sobre a autoria dos 32 hinos do MM 221. Se o MM 34 indica quase sistematicamente a autoria das obras nele constantes, porque não aquele? É evidente que o séc. xvi não é ainda, e assim será até muito depois, tempo de afirmação sistemática e peremptória da identidade do compositor promovendo o estatuto da autoria. Mas, sendo nós pós-românticos e pós-liberais, é-nos impossível sermos indiferentes à questão: um livro com 32 hinos polifónicos para todo o ano litúrgico, copiado com esmero apreciável apesar de apenas a preto, ganha um relevo e novos motivos de interesse se se lhe puder determinar o autor com o mínimo de plausibilidade.

Pois bem, o ponto de partida é esta ligação entre D. Francisco de $\mathbf{S t}^{\mathrm{a}}$ Maria - Francisco Mouro em Ciudad Rodrigo e na Capela episcopal de D. João Soares - e Diego Buxel, apelidado de "famoso maestro" (Elustiza e Castrilho Hernandez 1933: LXXIII), maior glória musical daquela cidade antes de Juan Esquivel (Ciudad Rodrigo, 1563-1625), filho de Giraldin Bucher imigrado da Gasconha. A primeira notícia de um Bucher na capela capitular de Ciudad Rodrigo data de 1494 em que foi

elegido cantor... Giraldin Bucher, apellido que fue transformandose en Buxer, Buxel, Bujel, con que es conocido. Era natural de Gascuña, de onde vino a Ciudad Rodrigo, atraído por las ricas raciones que se ofrecian. Tan 
perito era en el arte que, habiendose casado aqui con una señora de noble linaje, con lo que se hizo incapaz del beneficio eclesiástico, el Cabildo le conservó la ración en forma de salario.

Entre sus muchos discípulos descolló su bijo Diego Bujel, autor de un libro de himnos, versos de claustro etc que regaló a la catedral y que se ha perdido. Fue primero niño de coro. Contrajo matrimonio con una señora de la ilustre familia de los Aguilas, gozando la racion en forma de salario como su padre y ultimamente, habiendo enviuvado se ordenó de sacerdote. Hizo las oposiciones a la cantoria con un Ramirez (29/9/1522)... A 30 de Novembro [Setembro] ${ }^{38}$ de 1522, al salir de vísperas, "se da encomienda a Bucher la media prebenda y media ración en la forma que la tenia Altamirano" (Altamirano habia sucedido a Giraldin Bucher)". 39

Naturalmente, para fundamentar a convicção de que o MM 221 seja o livro de hinos de Diego Buxel, é muito pouco que ele tenha tido um discípulo que foi mestre de capela do Bispo D. João Soares, capela que possuiu um livro de hinos cujo autor não é nunca indicado. Além disso, a única notícia que tenho de tal livro de hinos de Diego Buxel é esta do séc. xx (1935) sem que o que a dá indique a fonte ou fontes que tenham preservado essa informação ao longo dos séculos.

Entretanto, adiante-se desde já que a hipótese de que o autor seja D. Francisco de $\mathrm{St}^{\mathrm{a}}$ Maria é de excluir, não só por razões desta vez sobretudo estilísticas, mas também porque à altura, em que por não mais de três anos foi mestre de capela de D. João Soares, estava praticamente a começar a sua carreira - teria passado pela Guarda não se sabe quanto tempo, mas seguramente muito pouco (cf. Pedro Miranda 2004: 234-8 e 243-6) - e, portanto, não tinha ainda tempo para apresentar uma colecção de hinos com esta dimensão. A composição não era naquele tempo um impulso interior ao modo

\footnotetext{
38 José Lopez-Calo (1975-77: 8) emenda para 30 de Setembro.

39 Mateo Hernandez Vegas 1935: 292. Cónego da Catedral, Vegas é até agora o mais importante historiador do Cabido e da Cidade. Percebe-se hoje, ao visitar o Arquivo Capitular, que ele viu muita documentação que entretanto se dispersou ou se perdeu, nomeadamente volumes de actas do cabido por ele citadas que hoje já não constam da série. Os trechos assinalados a negrito são da minha responsabilidade.
} 
romântico; era antes um ofício no sentido mais estrito do termo e, portanto, ditada pelas necessidades quotidianas e pelas cláusulas contratuais. ${ }^{40}$

Posto isto, proponho que se atente numa análise de 12 dos 32 hinos que tenho já transcritos, desde os aspectos mais periféricos, mas não irrelevantes, até aos mais nucleares do estilo e da própria técnica contrapontística que se possam ter como suportando uma espécie de assinatura do compositor.

O primeiro aspecto periférico que, não contribuindo positivamente para a força da hipótese, também não a contradiz é o facto de o Santoral do livro de hinos não ser fundamentalmente contraditório com a lista dos oragos mais significativos da diocese de Ciudad Rodrigo. Aliás, note-se a presença de um único hino mariano na colecção, o Ave maris stella, que, pela posição em que se encontra, é claramente destinado à festa da Assunção da Virgem Maria ${ }^{41}$, padroeira da Catedral e de mais 17 paróquias; entretanto, note-se ainda no santoral, além de hinos para os Apóstolos S. Pedro e S. Paulo, apenas e só mais um para $\mathrm{St}^{\mathrm{a}}$ Maria Madalena, orago de cinco paróquias.

O segundo aspecto periférico mas significativo e consequente com a proposta em análise é o facto de o cantus firmus do Pange Lingua ser claramente o da melodia da tradição moçárabe ainda hoje conservado nas colectâneas oficiais de canto gregoriano, o que imediatamente coloca a composição em espaço ibérico. Entretanto, se entre os hinos de maior popularidade entre os polifonistas, como o Ave maris stella, ou Veni creator, os cantus firmi são as melodias tradicionais que se impuseram no processo de unificação litúrgica do Ocidente, outros há que recolhem outras melodias - Jesu nostra redemptio - ou que usam versões parentes mais ou menos afastadas das que se impuseram nos hinários da reforma oitocentista e novecentista do reportório - $\mathrm{Ad}$ cenam agni. Nestes dois últimos casos, foi possível encontrar uma solução claramente mais aproximada no hinário de Huesca (província de Saragoça),

\footnotetext{
40 A título de exemplo, considere-se o já referido Juan Esquivel que, tendo começado a sua carreira de Mestre de Capela em Oviedo também na casa dos vinte anos (1581), veio a trazer à luz a sua primeira publicação, um livro de missas, em Salamanca mais de vinte anos depois, em 1608. Cf. Samuel Rubio 1983: 193.

41 Este hino regista uma grande variedade de festas marianas a que é aplicado. Para se ter uma ideia, é elucidativa a consulta de CANTUS: A Database for Latin Ecclesiastical Chant Indices of chants in selected manuscripts and early printed sources of the liturgical Office: bttp://cantusdatabase.org/ (em 7/11/2011). Dos numerosíssimos espécimes deste hino registados em manuscritos, cerca de 47 são destinados à Assunção.
} 
de finais do séc. xi (António Durán Gudiol; Ramón Moragas; Juan Villareal 1987), copiado além-pirinéus para a reforma e unificação litúrgica gregoriana que veio a dissolver o rito hispânico.

Ao nível do estilo, temos de ter em conta a habitual maior rigidez formal dos hinos polifónicos, nesta época quase sistematicamente elaborados numa técnica muito estrita de cantus firmus, de modo que não é neste âmbito que podemos esperar aquela liberdade e criatividade formal dos motetos ou mesmo das missas. Ainda assim, e no contexto de que o nosso ponto de vista é retrospectivo de D. Francisco para Diego Buxel, da comparação entre a Missa Bruxel do MM 9 (Pedro Miranda 2001: 72-74) e a Missa O beata Maria de D. Francisco de $\mathrm{St}^{\mathrm{a}}$ Maria, do MM 3 (ibidem: 79-82), pode-se retirar o seguinte: a segunda corresponde muito mais ao modelo da missa consagrada no séc. xvi, lançada sobretudo por Josquin des Prés e apropriada pela escola romana, que usa, é certo, as técnicas da paráfrase e outras elaborações contrapontísticas relacionadas com as tradições do cantus firmus e do cânone, mas em que impera a sistematização e equilíbrio da imitação na extensão a todas as vozes, a distribuição e demarcação clara do texto por cadências de ligação, a alternância com trechos de homofonia ao gosto do moteto livre - características que se conjugam para melhorar a inteligibilidade do texto. Se é verdade que, quanto à distribuição do texto pelo discurso polifónico, Diego Buxel já apresenta um estilo bastante claro, no entanto, a menor sistematização da imitação e o menor equilíbrio na sua extensão a todas as vozes não obtêm uma concentração sobre o texto tão conseguida.

Neste quadro comparativo, os hinos que temos em consideração, pelo facto de o serem e se revestirem da referida rigidez formal dentro da técnica do cantus firmus, acentuam naturalmente características geralmente arcaizantes, pelo que, do ponto de vista da relação entre texto e música, a comparação com a Missa Bruxel do MM 9 não resulta especialmente ilustrativa da tese de que se trate de obras do mesmo compositor.

É necessário, portanto, procurar naqueles pormenores de técnica contrapontística, pequenos "gestos" melódico-polifónicos que, repetindo-se com alguma frequência nas obras de um mesmo compositor, são como que suas assinaturas veladas. Retrospectivamente a partir de D. Francisco, assumo três suas “assinaturas” recenseadas por Owen Rees (1995: 153) e que ocorrem 
também na Missa Bruxel. São elas: o uso muito liberal de figuras de cambia$t a$, frequentemente com mais do que três notas -4 ocorrências; quintas ou quartas paralelas muito evidentes entre notas de passagem simultâneas em duas vozes ou entre uma nota de passagem e uma figura de cambiata - 3 ocorrências; nota retardada e aquela para que deverá resolver soando simultaneamente - uma ocorrência (Pedro Miranda 2001: 74). De todos estes traços de técnica polifónica o que chama mais a atenção é sem dúvida o terceiro, por ser algo seguramente muito raro. ${ }^{42}$

Pois bem, da transcrição e análise de 12 dos 32 hinos, resulta o mesmo quadro, destacando-se a evidência da mesma ordem de relevância pelo número de ocorrências que Owen Rees já verificava em D. Francisco.

Hinos com os três traços característicos em conjunto:

\section{Ad cenam agni}

Petrus beatus

Pange lingua

Christe redemptor omnium

Ut queant laxis

Hino com cambiatas a produzir quartas ou quintas com notas de passagem: Sacris Solemnis

Todos os outros têm abundante presença dos outros dois traços característicos.

Considerando o levantamento do número total das ocorrências nos 12 hinos em conjunto, o resultado é o seguinte: número total de cambiatas, 75; de quartas ou quintas em notas de passagem, 20; de cambiatas produzindo quartas ou quintas, 5; de ocorrências de nota retardada coexistente com a de resolução: 5

Note-se, novamente, como o número de ocorrências acaba por ditar, pela ordem decrescente, a mesma apresentada por Owen Rees, que foi quem primeiro as definiu, como acima citado.

42 Renato Dionisi e Bruno Zanolini 1996: 113. Um dos dois exemplos apresentados é de Vitória. Os autores precisam que "il momento della dissonanza ha sempre la durata di una sola croma, a causa della risoluzione anticipata". No entanto, nestes hinos em apreço a dissonância chega mesmo a acontecer sem essa resolução antecipada. 
É evidente que fica muito ainda por explicar para além da possibilidade razoável de D. Francisco de $\mathrm{St}^{\mathrm{a}}$ Maria tornar possível a presença em Coimbra, na capela episcopal, do livro de hinos do seu mestre, naquela altura já de idade bem provecta. Teria trazido consigo uma cópia? Teria encomendado executar uma depois de se estabelecer em Coimbra? Não estamos em condições, nem sei se é possível que alguma vez venhamos a estar, de quanto a isso obtermos notícias ou provas certas. Que o quadro é perfeitamente admissível, não tenho grande dificuldade em afirmar. Em primeiro lugar, se a mais que provável explicação para se encontrar uma missa de Diego Bruxel em Coimbra é o seu discípulo D. Francisco de $\mathrm{St}^{\mathrm{a}}$ Maria, porque não o há-de ser também para o livro de hinos cuja memória perdurou pelo menos até ao início do séc. xx? As notícias do prestígio de que gozava Diego Buxel permitem conceber tal iniciativa do seu discípulo. Em segundo lugar, há a considerar as relações históricas entre Coimbra e Ciudad Rodrigo; embora a sua consistência no séc. XVI não seja possível de avaliar, seria presumivelmente maior naquela época do que hoje. De facto, para além da instabilidade das fronteiras eclesiásticas daquela região entre Portugal e Castela, desde 1182 um mosteiro dos arredores da cidade tinha-se filiado no de $\mathrm{St}^{\mathrm{a}}$ Cruz de Coimbra assumindo a sua regra; sabe-se que no séc. xviI, era de obediência premonstratense, ${ }^{43}$ uma outra congregação de vida canónica observante da regra de $\mathrm{St}^{\circ}$ Agostinho e a única que no reino de Castela e Leão assumiu estruturas federativas estáveis (Miguel Calleja Puerta 2009: 53-4). Entretanto, o bispo D. Pedro de Castelo Rodrigo, passando por Coimbra, fizera-se familiar do mosteiro de Santa Cruz e veio mesmo em 1186 a doar àquele mosteiro a paróquia de S. Miguel de Ciudad Rodrigo (Armando Alberto Martins 2003: 879, nota 529) anexa ao referido mosteiro de Santa Cruz de Cortes (Miguel Calleja Puerta 2009: 51; Agustín Herrero Durán 2002).

Independentemente da impossibilidade de, para já, determinar com precisão as circunstâncias em que o tido por desaparecido livro de hinos de Diego

43 Armando Alberto Martins 2003: 878-80. É de admitir que a mudança de filiação se tenha dado por ocasião da reforma imposta por D. João III à congregação de Santa Cruz de Coimbra a partir de 1527, liderada por Frei Braz de Braga, e cuja nova observância veio a ser aprovada pelo Papa Paulo III, incluída a constituição de uma congregação propriamente dita cuja cabeça será, a partir de 1557, o Mosteiro de Coimbra. É sabido que não foi pacífica, tanto que só 22 dos 72 cónegos a aceitaram. Cf. Bernardo Vasconcelos e Sousa (coord.) 2005: 191. 
Buxel tenha chegado a Coimbra - se trazido por D. Francisco, se pedido por ele depois de estabelecido na Capela musical de D. João Soares -, os indícios estilísticos a evidenciar o mesmo métier do compositor da Missa Bruxel do MM 9 e as suas pegadas no métier de D. Francisco de $\mathrm{St}^{\mathrm{a}}$ Maria são abundantes e convincentes o suficiente para, enquanto não surgir dado fortemente contraditório, me parecer razoável trabalhar neste âmbito temático da polifonia de Coimbra do séc. xvi tendo em conta a afirmação em tese de que o MM 221 da Biblioteca Geral da Universidade de Coimbra é esse livro. ${ }^{44}$

\section{Bibliografia}

Agustín Herrero Durán (2002) "Historia de las parroquias mirobrigenses (IV). San Pablo-Franciscanos, Clarisas y columbarios" in Suplemento del Boletín Oficial del Obispado de Ciudad Rodrigo, 73.

<http://www.diocesisciudadrodrigo.org/contenidos/hdiocesana/hojasdiocesanas/ iecr73.htm>

António Durán Gudiol; Ramón Moragas; Juan Villareal (1987) Hymnarium Oscense. Zaragosa, Seccion de Musica Antigua, Instituición Fernando El Católico.

Armando Alberto Martins (2003), O mosteiro de Santa Cruz de Coimbra na Idade Média. Lisboa, Centro de História da Universidade de Lisboa.

Bernardo Vasconcelos e Sousa (coord.) (2005), Ordens Religiosas em Portugal. Das origens a Trento - Guia histórico. Lisboa, Livros Horizonte.

C-M Briquet (1907), Les Filigranes. 4 vols. Paris.

Ernesto Gonçalves de Pinho (1981), Santa Cruz de Coimbra, centro de actividade musical nos séculos XVI e XVII. Lisboa, Fundação Calouste Gulbenkian.

Fernando Fuentes Moro (1995) "Santoral Hispanomozárabe en la Diócesis de Ciudad Rodrigo”, in Memoria Ecclesiae 6 : 555-8.

44 Já depois de o trabalho estar pronto para a edição, chegou ao meu conhecimento o trabalho de NELSON, Bernadette, "A Polyphonic Hymn Cycle in Coimbra", KNIGHTON, Tess, NELSON, Bernadette (eds.), Pure Gold: Golden Age Sacred Music in the Iberian World, Edition Reichenberger, 2011, pp. 167-205. Não foi possível verificar em tempo útil a incompatibilidade ou complementaridade de resultados das duas investigações.

Dos doze hinos transcritos e analizados, um, Ad cenam agni, foi publicado em Revista da Academia Martiniana 6 (2002) pp. 34-44. Entretanto, com o grupo vocal Ançãble, que dirijo, tive oportunidade de gravar em concerto na Igreja de $\mathrm{St}^{\circ}$ António dos Portugueses, em Roma, o hino Christe Redemptor (in Conceptio Gloriosae Virginis Mariae \& aliae conimbricensium auctorum sacrae cantiones, (C) Istituto Portoghese di Sant'Antonio in Roma, PCD200517). Outros têm vindo a ser estreados em concertos vários, assumindo nos programas a atribuição a Diego Buxel (Ciudad Rodrigo ?- post 1572). 
José Lopez-Calo (1975-77), La musica en las catedrales del Reino de Leon. Ciudad Rodrigo: Actas capitulares. I (1443-1794), (Documentos 1-1478). Fundación Juan March, Madrid.

Juan B. de Elustiza e Gonzalo Castrilho Hernandez (1933), Antología musical: siglo de oro de la música litúgica de España : polifonía vocal siglos XV y XVI. Barcelona.

Mateo Hernandez Vegas (1935), Ciudad Rodrigo; la catedral y la ciudad, Vol. I, Salamanca.

Miguel Calleja Puerta (2009), "Los canónigos regulares en los reinos de León y Castilla", in José Angel García de Cortázar y Ruiz de Aguirre; Ramón Teja Casuso (coords.) Entre el claustro y el mundo. Canónigos regulares y monjes premonstratenses en la Edad Media, Aguilar de Campo, Fundación Santa María La Real, Centro de Estudios del Románico: 37-62.

Owen Rees (1995), Polyphony in Portugal, c. 1530-c. 1620. Sources from the Monastery of Santa Cruz, Coimbra, Garland Publishing, Inc., New York \& London.

Pedro Miranda (2001), D. Francisco de St ${ }^{a}$ Maria, cantor mor de Santa Cruz de Coimbra. Tese apresentada à Faculdade de Letras da Universidade de Coimbra.

Pedro Miranda (2004), "D. Francisco de St ${ }^{\mathrm{a}}$ Maria, Cantor Mor de St ${ }^{\mathrm{a}}$ Cruz de Coimbra: novos dados biográficos”, Estudos Teológicos 8: 229-257.

Renato Dionisi e Bruno Zanolini (1996), La tecnica del contrappunto vocale nel Cinquencento. Milano, Edizioni Survini Zerboni.

Samuel Rubio (1983), Historia de la música española. Madrid: Alianza Editorial.

Silvestre (1843), Alphabet-álbum, Collection de soixantes feuilles d'Alphabets historiés et fleuronnés tirés dês principales bibiotèques de l'Europe ou composés par Sivestre, professeur de caligraphie dês princes, cravés par Circault. Paris, J. Techener. 
Amparo Carvas Monteiro

Escola Superior de Educação de Coimbra

\section{DA PRÁTICA MUSICAL NO MOSTEIRO DE SANTA MARIA DE SEMIDE}

\section{Introdução}

Da longínqua e densa bruma dos tempos nos chega, uma vez mais, o toque festivo, mas sempre evocativo, do Mosteiro de Santa Maria de Semide para dar continuidade a uma liturgia multissecular, rica de ecletismo de símbolos e rituais religiosos.

Não se pretendendo este trabalho, nem exaustivo nem encerrado, seria desejável que a sua leitura suscitasse recordações de factos a que não tivemos acesso e a cuja comunicação nos mantemos abertos.

Na sociedade eminentemente rural e guerreira dos séculos XII e XIII, os grandes modelos culturais são os monges e os nobres, também orientadores da sociedade, à qual procuravam impor regras de procedimento e valores hierarquizados.

Antes do séc. XII já existiam diversos mosteiros dotados de coutos, bem como organizações episcopais e algumas colegiadas que, igualmente, dispunham de domínios próprios e ainda pequenas áreas que, em regra, pertenciam a cada igreja paroquial. Mosteiros como os do Lorvão, Arouca, Guimarães, Vacariça, Pedroso e outros já eram antigos quando foi erigido o Mosteiro de Alcobaça, entre 1148 e 1153, com base na doação de D. Afonso Henriques. No contexto destas organizações do clero regular, vivendo segundo a regra da respectiva ordem, destaca-se o Mosteiro de Santa Cruz de Coimbra (1131). 
Após a concessão do Condado Portucalense a D. Henrique ${ }^{45}$ e a D. Teresa são fundados novos mosteiros, enquanto outros são reformados ou se extinguem. Podendo ser do tipo familiar e frutuosiano distinguiam-se social e culturalmente: os segundos mais obedientes aos cânones da vida monástica, enquanto os primeiros assentavam nas fortunas das famílias dos fundadores ou protectores pertencentes à nobreza condal ou à nobreza rural da época, que neles mantinham a sua influência, como foi o caso do Mosteiro de Santa Maria de Semide, ligado à família Anaia.

A fundação do mosteiro de Semide está intrinsecamente ligada à reconquista cristã e ao progressivo alargamento do reino português no século xII, para sul, bem como à sua organização e povoamento.

Em 1131, o processo de Reconquista estava em curso e o Condado com Afonso Henriques assumia a luta pela independência contra Afonso VI (Mattoso 1993: 64). A mudança da corte de Guimarães para Coimbra, nesta data, foi "a mais transcendente de todas as decisões para a sobrevivência de Portugal como Nação Independente», sendo considerada "a cidade mais bem colocada para assumir a defesa do território face aos Árabes de que constituía fronteira» e donde se partiu "para a conquista de Lisboa e Santarém». De realçar também, a longa tradição de convivência desta urbe com os moçárabes - entre 1080 e 1116, foi importante foco de resistência contra a cultura dos clérigos vindos do Norte -, razão pela qual «ao fixar-se em Coimbra, D. Afonso Henriques, tornou-se o mais fiel protector de Santa Cruz e fez do mosteiro o centro cultural da corte» (Mattoso 1993: 68-69), contribuindo para que este se venha a tornar no centro cultural pujante e influenciador do resto do país.

A cidade mondeguina representa, então, o afastamento de Afonso Henriques da nobreza senhorial do Norte, que, ao aproximar o Norte do Sul e ao integrar a corrente pró-moçárabe, colocou em igualdade o condado portucalense e o de Coimbra, permitindo formar uma nação com regiões que se complementam.

Situada a cerca de duas léguas a sudeste de Coimbra e a um pouco menos de Miranda (do Corvo), numa área de grande potencial agrícola e na proximidade

\footnotetext{
45 A Crónica Sahagún refere que o rei D. Afonso VI «deu, com sua filha em casamento, Coimbra e a província de Portugal, que são fronteiras com os mouros» (Mattoso 1993: II-32).
} 
de um conjunto de locais fortificados da linha fronteiriça então estabelecida, Semide possuía condições favoráveis à fixação demográfica indispensável à prossecução da reconquista levada a cabo por D. Afonso Henriques.

O quadro cronológico da fundação e primeiros tempos do Mosteiro de Semide, elaborado a partir de informações sincrónicas recolhidas em fontes narrativas e diplomáticas dignas de crédito, insere estas datas: 1154, com a primeira comunidade monástica, masculina, a viver em Semide; e 1183, com a instalação das primeiras monjas beneditinas.

Com efeito, a carta de couto mandada passar por D. Afonso Henriques no dia 30 de Abril de 1154 demonstra a existência, naquele ano, de uma comunidade monástica beneditina masculina em Semide, admitindo-se que ela já pudesse estar instalada em data anterior. Este documento confere a qualidade de protectores do mosteiro a D. João Anaia, bispo de Coimbra (1147-1155) e a seu irmão D. Martim Anaia (e sua mulher Elvira Afonso), cavaleiro de Coimbra das hostes de D. Afonso Henriques, filhos de Anaia Vestrariz, asturiano e acompanhante do conde D. Henrique, a quem D. Teresa havia concedido a tenência dos castelos de Góis e Bordeiro.

A proximidade fronteiriça e a lógica militar levavam a que o monarca fizesse concessões, procurando compensar os homens que o apoiavam na guerra. A referida carta de couto de 1154 representa recompensa à família Anaia:

«[...] Ego Alfonsus ex divina providentia Portugalensium rex [...] cum regina Mahalda uxore mea vobis domno Iohanni abbati Sancte Marie de Semedi vestroque conventui et vestris successoribus in perpetuum facio cautum ad illam villam in qua monasterium edificatis, que est in territorio castri de Arouz et dicitur Semedi, de qua domnus Iohannes Colimbriensis episcopus et eius frater Martinus Annaye cum uxore sua Elvira Alfonsi et omnibus suis heredibus, me concedente [...]».

(P-Lan, Chancelaria de D. Afonso III. L I I Doações de Afonso III, fl. 21 v)

Por documento subscrito no ano de 1183, os filhos de Martim Anaia (com outros familiares) oferecem os direitos que têm sobre a Igreja de S. Pedro cum omnibus suis pertinentijs Deo et sancto Benedicto, para que sua irmã Sancha Martins e outras mulheres da mesma família pudessem estabelecer 
uma comunidade beneditina feminina em Semide. Com este documento possibilitam a formação desta nova comunidade com descendentes de Anaia Vestrariz, sendo a primeira Abadessa (1183), sua neta Sancha Martins, filha de Martim Anaia e de Elvira Afonso.

A saída dos monges e a instalação do mosteiro feminino permitiu continuar a receber, noviciar e professar outras familiares dos instituidores, mormente as descendentes das irmãs de D. Sancha que não viessem a casar. É de admitir que, para além das descendentes dos Anaia, mulheres de outras famílias da nobreza regional oriunda de outros cavaleiros de Coimbra tenham, então, ingressado no Mosteiro de Semide.

A partir da segunda metade do séc. XII, o desenvolvimento do monaquismo feminino traduz-se no aparecimento de novos mosteiros a par da transformação de cenóbios masculinos em residências de monjas.

A nobreza medieval tinha um interesse particular no controlo das instituições monásticas, sendo prática generalizada colocar nos mosteiros mulheres da nobreza de segundo grau, sobretudo em famílias com elevado número de filhas afastadas do casamento por razões de natureza sucessória e de linhagem.

A eleição para o cargo de Abadessa resultava, por regra, da estreita ligação desta à família instituidora do mosteiro, como é evidente no caso de Semide.

Os mosteiros foram centros difusores de religiosidade e de cultura e, simultaneamente, de grande relevância no plano material, no desenvolvimento, consolidação e defesa do património, o que contribuiu para o aumento gradual da sua importância e dos seus abades e abadessas.

Entre as monjas de Semide, existem referências a diversos cargos, entre os quais os de abadessa, prioresa, subprioresa, cantora-mór, segunda cantora, supridoras, mestra das noviças, sacristã, celeireira, escutas das grades, boticária e escrivã.

A abadessa era eleita pelas monjas, sendo a representante máxima da instituição, dentro e fora desta. Por exemplo, quando no séc. xiv a capacidade de desfrute sobre a área coutada foi ameaçada pelos poderes vizinhos, a abadessa de Semide invocou a carta de couto de 1154 , considerando que as monjas eram as naturais continuadoras da comunidade a quem a carta fora dirigida, justificando, assim, as prerrogativas e direitos possuídos. Por ocasião de uma demanda em que foram postas em causa as delimitações das propriedades 
monásticas, a abadessa sustentou que ao "dicto moesteiro de Semide foram dadas e outorgadas buuas grandes somas de terras e herdades as quaes deziam que lhis forom dadas e outorgadas per el rei Dom Afonso Anriquez [...] per divissooes e confrontaçães certas", vindo a ganhar a contenda (P-Cua, Pergaminhos avulsos, não numerados, de 20 de Agosto de 1363).

A prioresa era a segunda figura da instituição, cabendo-lhe algumas funções atribuídas pela abadessa. O carácter hierárquico da comunidade originava disputas pelos principais cargos, por serem aqueles cujo controle pela família patronal poderia garantir maior poder, influência e património.

Em 13 de Fevereiro de 1610, D. Afonso de Castelo Branco, bispo de Coimbra e conde de Arganil, fez deslocar as monjas beneditinas de Semide para o convento de Santa Ana que havia mandado construir na parte alta da cidade, para as religiosas de Santo Agostinho que já o habitavam. Esta mudança ocorreu em cumprimento de um breve emitido a seu pedido pelo Papa Paulo V que mandava extinguir o mosteiro de Semide, unindo-o ao de Santa Ana e passando para este todas as rendas, dízimos, direitos e propriedades daquele, devendo as monjas beneditinas semidenses conformar-se "no habito, e reza e divino officio, $e$ outros ritos e costumes regulares com a ordem de Santo Agostinho" (Benedictina Lusitana, cit. Assunção 1900: 34; P-Lan, Semide. Santa Maria, livro 1, maço 7).

Foi, porém, de curta duração esta medida, pois as recém-chegadas logo contestaram a mudança de hábito e de regra que lhes era imposta e manifestaram ao bispo-conde a sua vontade de voltar para Semide, isto é, para o seu Paraíso, como elas o denominavam. A notícia do protesto, que não foi inteiramente pacífico, alastrou pela cidade de Coimbra, tendo D. Afonso Castelo Branco, por provisão que mandou passar no dia 14 de Abril de 1610, permitido que regressassem a Semide as religiosas que assim pretendessem e permanecessem no convento de Santa Ana as que nele quisessem passar a viver, com nova regra e hábito. Como fundamento do protesto, as monjas invocaram desconhecer o teor do documento pontifício, por o mesmo não lhes ter sido previamente lido, nem dado a ler, para dele tratarem em capítulo. Após ter-lhes sido dado conhecimento do teor do documento, a maioria respondeu não consentir na mudança do hábito de S. Bento em que professaram, nem nas restantes imposições contidas no breve, regressando a Semide mais de dois terços das monjas que dele tinham vindo para Santa Ana. 
Diversos e importantes foram os privilégios concedidos ao Mosteiro de Semide. No que respeita à protecção real, pode referir-se um alvará de D. Pedro II que transcreve uma carta de D. Afonso V, colocando a abadessa, o convento e todos os seus bens sob protecção régia, a qual foi confirmada por D. João V. O mosteiro estava também isento de prestação de serviços nas obras na cidade de Coimbra, estando dispensado de nelas mandar comparecer os moradores do seu couto, privilégio que lhe foi concedido e confirmado por diversos monarcas. ${ }^{46}$ Estava ainda isento de prestação de aposentadoria e possuía jurisdição própria, com juiz eleito entre os moradores do couto (cuja eleição era ratificada pela abadessa), que julgava os litígios, podendo as partes em caso de discordância recorrer para a abadessa e desta para o rei.

As grandes mudanças políticas, os conflitos militares e epidemias tiveram consequências nefastas para o monaquismo. Por exemplo, a guerra da restauração, as invasões francesas, as lutas liberais, o corte das relações com a Santa Sé e sobretudo a extinção das ordens religiosas masculinas em 1834 e a situação de precaridade material das congregações femininas, que trouxeram às monjas de Semide "[...] duras privações [...] no aperto de uma clausura onde abundam mais as lagrimas de angustia do que o pão de cada dia" (Assunção 1900: 112). ${ }^{47}$ São provações desta natureza as que referem em carta de 31 de Março de 1843, dirigida à Câmara de Deputados do Reino, na tentativa de defesa dos seus direitos de propriedade sobre um conjunto de terrenos que possuíam nos campos de Coimbra, em ambas as margens do rio Mondego. Entre 1843 e 1845, as monjas tiveram de vender diversos objectos de prata para poderem comprar milho e outros mantimentos e estabelecer acordos com os credores para mitigar a penúria em que viviam.

\footnotetext{
46 Cf. De entre outros, P-Lan, Chanc. de D. João III, L ${ }^{\circ}$ 14, fl. 23; P-Lan, Confirmações Gerais, liv. 14, fl. 319 (em treslado de 4 de Dezembro de 1634, relativa à confirmação dos privilégios e jurisdições do couto de Semide, por D. Afonso IV, em 15 de Novembro de 1335); P-Lan, Semide, M. 182, n. 30; P-Lan, Semide, M. 182, n. 33; Chancelarias de D. Pedro I (1357-1367), p. 154-155 (n. 394); P-Lan, Doaç., L ${ }^{\circ} 62$ da Chanc. de D. Pedro II, fl. 262, carta (13 de Dezembro de 1701), de confirmação do direito de disporem de jurisdição própria); P-Lan, Chancelaria de D. João V, livro II, Padr. e Doações, fl. 76, carta (7 de Março de 1707), da confirmação de isenção do serviço de aposentadoria); P-Lan, Chanc. de D. João V, livro II, Pradr. E Doaç., fl. 72.

47 A reintrodução discreta das ordens regulares começou nos anos 60, sendo o seu crescimento tão significativo que, "nas vésperas da República, existiam em Portugal 31 congregações ou associações religiosas distribuídas por 164 casas» (Neto 2007:172).
} 
Por sua vez, Semide cuja existência remonta a tempos muito anteriores à fundação da nacionalidade portuguesa e que havia recebido foral ${ }^{48}$ de $\mathrm{D}$. Manuel no dia 13 de Janeiro de 1514, viu extinguir em 31 de Dezembro de 1853, o concelho de que foi sede até essa data.

Apesar das dificuldades, era forte a vontade das monjas de persistir no hábito, na regra e na casa em que haviam professado, pois em 5 de Janeiro de 1870, o governador do bispado de Coimbra consultou as religiosas que ainda se encontravam em Semide, sobre a sua vontade de se transferirem para outro mosteiro, ao que estas responderam negativamente.

Em Maio de 1882, ainda permaneciam no mosteiro três monjas (para além de mulheres residentes que continuaram ao seu serviço). A última monja do mosteiro beneditino de Santa Maria de Semide faleceu nele, no dia 21 de Agosto de 1896.

\section{Da igreja e do seu órgão histórico}

Da edificação medieval do cenóbio nada existe, presentemente. Devido a um incêndio que ocorreu em 1664, foi destruída a maior parte do mosteiro, sendo o actual o resultado de construções posteriores, sobretudo, dos séculos XVII e XviII. Num passado mais recente, em 16 de Agosto de 1990, o Mosteiro de Semide volta a ser vítima do fogo que consumiu o Claustro Velho, a Casa do Capítulo e a Sacristia.

A igreja foi edificada numa tipologia de ampla nave e capela-mor num dos topos e no outro está localizado o coro monástico. Da decoração sobressai a da capela-mor com diversas cenas da vida de S. Bento, sendo o retábulo em talha dourada, com duas esculturas, uma do patrono e outra de Santa Escolástica, atribuídas ao monge escultor beneditino Fr. Cipriano da Cruz. As paredes da igreja e do coro são revestidos a azulejos com motivos hagiográficos, de meados de Setecentos, de fabrico coimbrão.

\footnotetext{
48 Em virtude das muitas demandas e interpretações diversas que os letrados davam aos Velhos Forais, D. Manuel «mandou rever os cinco livros das Ordenações, nos quais mandou diminuir e acrescentar aquilo que lhe pareceu necessário para o bom governo do Reino", tarefa que levou 20 anos (Crónica do Felicíssimo Rei Dom Manuel, Cap. XXV).
} 
O templo está dividido em duas partes, ficando o coro separado por um arco com grades de ferro. No coro, na parede do fundo, está localizado o órgão histórico assente numa tribuna de madeira. A caixa do órgão em talha dourada é encimada pela figura do Rei David. Segundo o organeiro António Simões, que procedeu ao restauro do instrumento na década de 80 do séc. xx, a autoria do órgão tem vindo a ser atribuída a António Xavier Machado e Cerveira (1756-1828), provavelmente em 1788.

Porém, esta autoria e respectiva data não são conclusivas, tendo em conta, entre outros documentos, a existência de róis de despesas despendidas com alimentação do organeiro beneditino Fr. Manuel de S. Bento (autor do órgão setecentista da Real Capela de S. Miguel da Universidade de Coimbra), que referem várias deslocações deste a Semide e a Sandelgas. Com efeito, por motivo da construção do órgão da Capela da Universidade, frei Manuel de S. Bento esteve em Coimbra entre 1732 e 1734 e, posteriormente, em 1738 e 1745. Um daqueles manuscritos, datado de 11 de Novembro de 1734, está assinado pelo procurador do Colégio de S. Bento de Coimbra, Fr. António de São Gregório e por este entregue ao bacharel Mateus Monteiro, Agente da Universidade de Coimbra (P-Cua, Universidade de Coimbra. Contas (documentos diversos provenientes de várias repartições da Universidade). 1728-1737. (caixa de inumerados); Universidade de Coimbra. Contas. 1745 (caixa de inumerados); Monteiro 2002: 272-273; Monteiro 2004: 9-11). Não se pretende, contudo, atribuir-lhe a autoria do órgão do Mosteiro de Semide - aspecto digno de aprofundada investigação -, mas é de admitir a sua intervenção no mesmo.

Com a revitalização do ofício da organaria em solo português, a partir da década de 80 do séc. xx, alguns artesãos nacionais e estrangeiros começaram a dedicar-se ao património organístico do país, e graças a uma crescente consciencialização de alguns políticos e agentes culturais, encara-se, hoje em dia, com novo olhar a tarefa de conservação e de restauro dos órgãos de tubos históricos e modernos. Com efeito, entre 2002 e 2007, o instrumento histórico de Semide sofreu nova intervenção com grande critério e exigência, levada a cabo pelo organeiro Dinarte Machado.

O órgão do Mosteiro de Santa Maria de Semide é rico na composição de registos, tanto nos cheios como na base de sustentação daqueles, evidenciando um projecto de construção no sentido da variedade sonora de cheios, 
dos mais diversos timbres até à unidade artística da pirâmide harmónica, reforçado com os jogos palhetados, de acordo com informações amavelmente prestadas por Dinarte Machado.

\section{Observações organológicas}

Teclado de um só manual, cuja extensão é a seguinte: Lado esquerdo - C1 (dó1) | c 25 (dó 25); lado direito - c\#26 (dó\# 26) | f 54 (fá 54). Dois pedais que accionam os tambores acústicos, cada um com batimentos inferiores a um intervalo de meio tom: tambor de Dó e tambor de Fá; e outros dois: para anular registos cheios, assinalados com +; e anular registos de palheta em chamada, referenciados com *. Um puxador da campainha para indicações ao foleiro.

Composição do instrumento

\begin{tabular}{lll} 
MÃO ESQUERDA & & MÃO DIREITA \\
\cline { 3 - 3 } Trompa Batalha* & Clarim* \\
Trompa Real & & Oboé* \\
Cobre Símbala + & Trompa Real \\
Símbala + & Corneta Real \\
Clarão + & Símbala + \\
Vintedozena + & Nazardo + \\
Dezanovena + & Vintedozena + \\
Quinzena + & Dozena e $15^{\text {a }}+$ \\
Dozena + & Oitava Real + \\
Flautado de 6 tapado & Voz Humana \\
Flautado de 6 aberto & Flauta Romana \\
Flautado Violão & Flauta Travessa \\
Flautado de 12 aberto & Flautado de 12 aberto \\
& Flautado de 24 aberto
\end{tabular}

A registação é fundamental para a execução organística na liturgia. Ela dá a côr, o ambiente, prepara os momentos de maior densidade significativa de um cântico, torna-o mais vivo, ajuda a definir a sua função ritual, faz distinguir os vários momentos rituais pela na sua diversidade e importância, e contribui 
para a expressão de conteúdos da ação litúrgica. O organista pode em muito ser responsável por que determinada celebração aconteça de modo vivo e dinâmico, pela clara diferenciação das partes e por uma expressão musical bem integrada nas ações, permitindo, a todos, também através da música instrumental (a solo ou não) melhor e mais ativa participação (Antunes 1996: 186 ss). Em síntese, quem domina bem os materiais através de uma técnica aperfeiçoada, pode, com o seu talento, produzir uma obra de arte, com inegável nível artístico e qualidade estética. Só assim é verdadeira arte ao serviço da liturgia, exprimindo com a linguagem que lhe é própria (linguagem dos sons) e com a sua beleza expressiva, os valores da fé (Ibidem: 207).

O mosteiro semidense possuía também um clavicórdio (ou manicórdio, como também é denominado em algumas fontes) construído em meados do século xviII, referenciado no Catálogo da Exposição da Fábrica de Sons, Instrumentos de Música Europeus dos Séculos XVI a XX, editado em 1994, e por autores como Gerhard Doderer (1996) e Elisa Lessa (1998). A prática deste instrumento na corte portuguesa já se verificava no séc. xv, conforme carta de 22 de Setembro de 1428, do Infante D. Henrique, escrita em Coimbra para D. João I, seu pai, dando-lhe notícias suas e dos irmãos, especialmente a relatar-lhe como decorrera o casamento do infante D. Duarte com a infanta D. Leonor, então ali celebrado:

«O jffante meu senhor em ver damçar e camtar e em qualquer outra cousa que pode filhar prazer filhao de bom tallamte e he bem ledo e bem saao, a Deus graças. E louua mujto ho camtar da senhora a jffante e ho seu tamger do manicórdio e do damçar segumdo sua maneira, e asi dizem que baijlha».

(Monumenta Henricina 1961: III-256)

O clavicórdio era um instrumento especialmente adequado às funções exigidas e ao estudo individual da vida conventual das grandes congregações como sejam de Beneditinos, ou Agostinhos Regrantes, sendo a arte da sua construção uma tradição nacional. Em Coimbra, a oficina de instrumentos do mosteiro crúzio e a vida comunitária do mesmo, estava organizada no sentido de uma auto-suficiência, quer do ponto de vista material, quer sob o ponto de vista cultural. As fontes são abundantes e demonstradoras dessa prática 
longínqua, como refere Gerhard Doderer (1999: 35; 2005: 10), ao noticiar a visita de D. João III, no ano de 1550, à oficina da comunidade crúzia. Nos anos Quinhentos e Seiscentos, a construção e execução de manicórdios ou clavicórdios teve diversos frades dedicados, de que se destacaram D. Luís, D. Baptista de São João, D. Jerónimo dos Anjos, entre outros (Pinho 1981: 156).

\section{Da música no quotidiano das monjas}

A entrada nos conventos beneditinos estava regulada e exigia um conjunto de requisitos. Por exemplo, o ingresso era acompanhado de um dote, embora estivesse previsto que a candidata pudesse entrar sem aquele, desde que possuísse conhecimentos musicais (ingresso pela prenda de solfa e organistas), como se infere do relatório de Visita efectuada ao Mosteiro de S. Bento de Bragança, pelo Visitador Fr. Pedro de Melo, em 1698. As normas eram válidas e extensivas a todos os conventos femininos beneditinos. Dispunha o relatório:

«[...] ordeno que as muzicas examinem as freiras que tiverem melhores vozes e as ensinem, e que lhe dem lição todos os dias, a qual basta, que seja de duas horas; e que as freiras com mais temor e cuidado aprendao, e se exercitem em a solfa, mando se lhe dê de propina, mais que as outras um tostão, para que não percao o tempo em que podiao granjar pello seu trabalho alguma cousa para sua passagem [...].

[...] Também me parece conveniente que as muzicas que na religião estaõ, e entram sem dote e as tomou o convento para o ministério de ensinar e cantar, as Preladas, as não ocupem em nenhum officio da religião, excepto aquelles que pertencem ao choro, cujo exercicio he necessario para com mais decencia se celebrar o culto divino [...]».

(P-Lan, Bragança, S. Bento, cx. 1, cit. Lessa 1998: 98)

Tal como a transcrição nos indica, também Em Vozes do Convento, nos é dito que às «senhoras músicas, cantoras e tangedoras de órgão, eram concedidos privilégios próprios - dispensa da Hora de Noa, flores e alimentação 
especial - fruto do reconhecimento dos seus dotes e da importância do serviço prestado à comunidade» (Lessa 2011: 587).

A admissão da noviça era precedida de uma habilitação de genere. De entre os requisitos, a postulante deveria ter pelo menos 15 anos. Contudo, diversa documentação revela ter sido lançado o hábito a meninas com menos idade. O cerimonial para a entrada no noviciado descrito por Tomás Lino d'Assunção (1900) e Elisa Lessa (1998), evidencia a preparação, com a indispensável componente musical.

A solenidade ocorria, após proposta de admissão pela abadessa do mosteiro e votação e aceitação pelas monjas em capítulo, depois do ofício de Vésperas. A entrada era precedida de um diálogo entre a noviça e a abadessa que lhe lia a regra e seguidamente lhe lançava o hábito, entoando as monjas cantoras o hino Veni Creator Spiritus.

Ao longo de um ano de noviciado, seria submetida a três provas públicas e, vencidas estas, estaria apta para professar. Com o início do noviciado, começava também a sua vida de provações, ao longo de um ano, sob a responsabilidade da Mestra de Noviças. Esta, segundo a Regra, tinha a seu cargo a instrução, devendo "exercitar estas [as noviças] muito na oração, meditação, lição de livros espirituais, frequência de sacramentos, em jejuns, vigílias, cilícios e disciplinas [...] e cuidar que não falem com seculares, ainda que sejam parentes", não podendo "estar à conta ou em companbia de suas tias, ou parentas [mesmo as que estivessem no mosteiro]» (Assunção 1900: 67) e, apenas com a sua Mestra a quem competia a instrução - no Latim (por vezes no Português) e na Música, para entoar e acompanhar os cantos litúrgicos -, no primeiro ano do coristado.

Findo o ano do noviciado e tendo ultrapassado as provas impostas, a noviça seria admitida à profissão de fé, com parecer favorável da mestra e voto favorável das monjas.

Nesta nova cerimónia, depois de proferir o texto da profissão, a noviça entoava com a Cantora e a Mestra das Noviças a antífona Suscipe Domine, com acompanhamento de órgão. Seguidamente, dirigia-se ao altar onde depositava a sua carta de profissão. Prosseguia a cerimónia estando a noviça estendida no chão no meio do coro. O hábito era benzido e entoado o versículo que diz "Levanta-te tu que dormes. Ressurge da morte e que Cristo te ilumine». 
Após ser cantada novamente a primeira estrofe do hino Veni Creator Spiritus, a professa recebia de joelhos a cogula negra, terminando a cerimónia com o celebrante a entoar o Te Deum, enquanto na torre repicavam os sinos, anunciando o fim da cerimónia.

Após o noviciado, a formação dos monges e monjas beneditinas prosseguia durante anos, como indicam as Constituições da Ordem de S. Bento (Lisboa 1590), capítulo XXXIII. Os responsáveis da Ordem tinham a preocupação de que nos mosteiros houvesse ensino e prática musical de qualidade. As observações sobre os seus benefícios e a relevância do papel da música no quotidiano das monjas estão patentes em actas de visitações e outras fontes. A existência de horas diárias de canto e de prática instrumental estavam previstas e reguladas.

O Regulamento da Comunidade do Mosteiro de Santa Maria de Semide, datado do séc. XVII, disciplinou a vida diária no convento nos seus diversos aspectos, tais como, as regras sobre silêncio e recolhimento, as horas do Ofício e da Missa e a actividade musical vocal e instrumental. Refere, por exemplo, a existência de quatro cantoras, devendo a cantora-mor "governar e reger o coro, levantando salmos e hinos, levantar ou baixar o tom quando se cante mais de presa, ou mais devagar mas não deixar de cantar, o que for por Lei ou custume [...]" (P-Lan, Semide, Santa Maria, livro 2). No âmbito das suas funções era responsável pela direcção musical do canto litúrgico, não lhe competindo porém, decidir sobre a intervenção do órgão, aspecto que competia a quem presidia à cerimónia (Cerimonial da Congregação de S. Bento. Coimbra, 1647, livro I, título 2, cap. II).

Havia diariamente, de manhã, dois períodos destinados ao estudo do cantochão (podendo um deles ser reservado à aprendizagem de um instrumento de tecla) e outro com igual finalidade durante a tarde. Para se exercitarem na prática do órgão, deveriam tocar por turno cada uma em seu dia, e as mais adiantadas ensinar as outras monjas (P-Lan, Semide, Santa Maria, maço 8).

Também As Constituições Municipaes do Real Mosteiro de Santa Maria de Semide, aprovadas e confirmadas pelo Excelentíssimo Senhor Bispo Conde Francisco de Lemos Faria Pereira Coutinho, datadas do séc. XviII, dispunham sobre a prática musical litúrgica. Por exemplo, o cap. IX destas Constituições contém as normas para a realização do oficio divino: 
"[...] As Preladas porem mandamos, e sobre isto lhe encarregamos gravemente as suas consciências, porque vigiem muito a perfeição da celebracao do officio Divino que frequentem o Coro, cuidem, que nada con velecidade, de corrida, com pressa, ou confusamente se recite, mas de espaço e com as costumadas pauzas e [...] a respeito do canto determinão também ao Convento varias, e muitas coisas, de como, e quando devem ser cantadas, entoadas ou rezadas as suas horas canónicas, consta igualmente o cerimonial [...]. As Vésperas, Terça e Missa maior sempre devem ser cantadas, segundo a mesma constituição e acabadas se cantara quando a Prima for cantada, e ainda então sem maior solenidade, mas com outra qualquer lição sem órgão, nem mais luzes acesas [...]. Façao as Religiosas e assim se lhes mande por uzar antes do officio Divino do cantochão simples e uniforme, quanto ao do canto d'orgam ou contraponto, e mesmo que talvez se procura mais agradar aos homens, que a Deus. Por isso só com Licença do Prelado paracendo justo se poderá usar do canto d'orgam, e nunca instrumental. Do mesmo orgao se não deve uzar em Officios de Deffuntos, nem nos de Semana Sancta, nem em outras funções que a Igreja o não admite, de que as Religiosas, e principalmente organista devem ser instruídas [...]».

(P-Lan, Semide, Santa Maria, Livro 1)

Nem sempre a disciplina do convento esteve de acordo com os cânones da moral laica e menos ainda com os da moral religiosa. Houve, por vezes, situações de ruptura que motivaram a intervenção da hierarquia da Igreja e até dos monarcas, com sucessivas proibições dos Prelados Visitadores.

É bem clara a proibição contida nas Constituições Municipaes do mosteiro: [...] probibe, e manda tambem as Religiosas, que nem ainda por breves horas se vistaõ de vestidos seculares, mui menos de bomens para representações, nem comedias, nem Actos Sacramentaes, nem de vidas de santos ou santas [...] (P-Lan, Semide, Santa Maria, Livro 1).

Porém, apesar das proibições, a vida das monjas tinha momentos de fuga à rotina diária, tendo o teatro um papel importante. Em Semide, à semelhança dos restantes mosteiros da ordem, eram representados autos religiosos e profanos (especialmente realizações poético-musicais onde o vilancico ou 
chansonetas tinham um papel proeminente) com o pretexto de dar maior brilho a algumas cerimónias, como a celebração do Natal, de S. João Baptista, de S. João Evangelista, ou mesmo um novo abadessado. A representação antecedia a cerimónia litúrgica e terminava com o Te Deum ou Magnificat. Por vezes, após a representação, seguia-se a Missa, participando nela todas as intervenientes no auto que, para o efeito, tinham usado indumentárias adequadas às respectivas personagens. Estas representações começaram por ter lugar na Capela-Mor, depois no Coro e, mais tarde, nos claustros e até nas celas das abadessas, com convidados.

Tomás Assunção (1900: 187ss.) refere a representação de vários autos no Mosteiro de Semide como, por exemplo, o Auto Plausível, o Auto dos Três Pastores, o Auto do Espírito Santo e o intitulado Brinquedo jocoso representado em noite de Natal, sem indicação de data, relativamente ao qual transcreve a seguinte rubrica :

"[...] acabando de recitar-se a última quadra do motteto cantado, entra pela porta do aposento uma velha que representa uma moça (criada) da pomareira com um trajo proprio, e fica á porta vendo se, mas não entrando. Uma senhora em trage de pastor com chapéo desabado, cajado, sapatos tacheados e traz um cordeirinho debaixo do braço, encoberto com o lenço; e a velha vem esbaforida e cançada [...]».

Pela transcrição podemos também apurar que a temática dos textos não sofreu alteração profunda, pois o elemento pastoral, típico no vilancico do séc. XV e Xvi continuou a ser a grande regra nos séculos seguintes.

A festa que mais requeria vilancicos era a do Natal, o período mais alegre do ano litúrgico, tendo a configuração musical da sua celebração cambiantes distintas, cujo grau de festividade é expresso pela música através da escolha das partes que se cantam, do modo como são cantadas, da riqueza, grau de participação e articulação dos diversos intervenientes.

A tradição adoptada pela Capela privativa dos Duques de Bragança, em Vila Viçosa, de se cantarem vilancicos não só no Natal, mas também no dia da Imaculada Conceição (8 de Dezembro) e na festa dos Reis (6 de Janeiro), foi mantida senão mesmo reforçada por D. João IV, o que também nos é 
revelado nos fundos de Semide. ${ }^{49}$ Porém, a execução deste género musical sofreu alterações no reinado de D. João V, que os considerava "uma tradição primitiva", pelo que foram excluídos do culto na Capela Real e, proibidos em todas as igrejas do Reino e colónias, em 1717 e 1723, respectivamente (Horch 1969: 56; Nery 1997: 97, 101). Este monarca desejava «tornar Lisboa mais papista do que Roma" (Stevenson 1976: XI) e, de facto, a Capela Real foi remodelada à «maneira da liturgia e do ritual do Vaticano» e de acordo com as «orientações estéticas e dimensões monumentais da Capela do Papa» (Nery 1991: 87).

A influência e a prática da música profana na vida do Mosteiro de Semide foi realidade. A confrontação dos elementos profanos com os padrões sagrados tradicionais, vivida na comunidade religiosa semidense são o melhor testemunho da vitalidade dessa prática musical. Música, poesia, dança e teatro, foram ao mesmo tempo oração, arte, divertimento e espectáculo em que se combinou o som, a palavra, a cor, o gesto e o movimento.

Em Vilancicos do Século xVIII do Mosteiro de Santa Cruz de Coimbra (1983), Manuel Carlos de Brito, referindo-se a um conjunto de manuscritos musicais constituídos por Vilancicos e Romances na sua maioria anónimos, sublinha a influência do Mosteiro de Santa Cruz e a produção de algumas obras destinadas ao Porto, a Braga, Guimarães, Viseu e Semide: Tonos e Chançonetas de Natal (P-Cug Ms. 227) que possui vários Romances, Loas e Comédias; e Cansonetas de Natal e Hymno de nosso Padre Dom Gabriel de S. João Cartapacio.15. (P-Cug Ms. 240).

O MM $M^{50} 238$, proveniente dos fundos do Mosteiro de Santa Cruz, evidencia o destinatário e a data ( $\mathrm{P}^{\mathrm{a}}$ Simide|1645), título e padrão formal da composição: Chansonetas de Natal Cartapacio. 14. para dois coros, coro 1: S 1, 2, C 1, 2; coro 2: S, C 1, 2, T, B (guião), de que se apresenta excerto:

\footnotetext{
49 No entanto não nos é possível apresentar ou mesmo enumerar alguns desses documentos na medida em que o fundo de Semide está, presentemente, a ser tratado - num total de 89 livros e 36 maços -, não estando, pois, acessível ao público.

50 No canto superior esquerdo da folha de rosto está patente o ex-libris da Polyphonia (Schola Cantorum), facto comum em muitos outros manuscritos da P-Cug, por doação feita da Acção Cultural da Fábrica de Aveiro, e iniciativa de Mário Sampaio Ribeiro.
} 


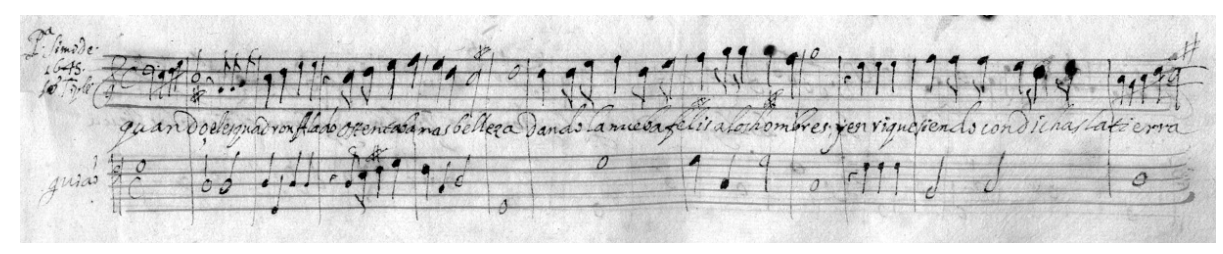

P-Cug, Quando el squadron Alado ostentaba mas belleza dando La nueba felis a los hombres, fl.6.

Ao longo da história tem sido diversa a posição da Igreja sobre determinadas práticas e uso de instrumentos na liturgia, sendo esta influenciada pelo contexto músico-cultural da época. Da mesma forma foi mais ou menos mantida a dicotomia entre instrumentos de natureza profana e sagrada, referindo-se no entanto o órgão como instrumento por excelência para a música litúrgica.

É-nos, pois, permitido concluir ter havido no mosteiro um tempo de organização e implementação litúrgica e musical, regulada e controlada, de estabelecimento de bases conducentes a uma efectiva realização musical, visível no cumprimento do cerimonial litúrgico beneditino, na participação obrigatória em todas as cerimónias litúrgicas, em especial das monjas "músicas" e cantoras, no ensino diário do canto a todas as religiosas e nas advertências sobre a representação de vilancicos, género poético-musical que nos mosteiros beneditinos surge tanto associado a cerimónias festivas integradas na liturgia como em momentos informais, particularmente apreciados em Semide.

A documentação estudada permite traçar um quadro da actividade musical que existiu na comunidade semidense no triplo papel (litúrgico, educativo e lúdico), que a música assumiu na vida comunitária. É, igualmente, evidente o contributo significativo desta comunidade e da sua intensa actividade musical quotidiana continuada de forma profícua, no desenvolvimento da arte organística e na arte de construção deste instrumento. 


\section{Referências Bibliográficas}

P-Cua, Coleção Coronel Belisário Pimenta. Miranda do Corvo. Semide. Foral Manuelino do Couto de Semide (1514).

P-Cua, Coleção Coronel Belisário Pimenta. Documentos diversos (1695-1856).

P-Cua, Semide. Pergaminhos avulsos, não numerados, de 20 de Agosto de 1363.

P-Cua, Semide. Pergaminhos avulsos: cx de pergaminhos não numerados.

P-Cua, Universidade de Coimbra. Contas (documentos diversos provenientes de várias repartições da Universidade). 1728-1737. (caixa de inumerados).

P-Cua, Universidade de Coimbra. Contas. 1745 (caixa de inumerados).

P-Cug, MM. 238, MM 227, MM 240, MM 535, MM 704.

P-Lan, Bragança, S. Bento, caixa 1.

P-Lan, Depósito, Cartório de Semide, n. 180.

P-Lan, Semide. M. 182, n. 30 e n. 33.

P-Lan, Chanc. de D. Afonso III. L I I de Doações de Afonso III.

P-Lan, Chanc. de D. Pedro I (1357-1367), p. 154-155 (n. 394).

P-Lan, Chanc. de D. João III, L $\mathrm{L}^{\mathrm{o}}$ 14, fl. 23.

P-Lan, Chanc. de D. João V, L II, Pradr. e Doações, fl. 72 e 76.

P-Lan, Confirmações Gerais, liv. 14.

P-Lan, Doaç., L 62 da Chanc. de D. Pedro II, fl. 262 e 262 v.

P-Lan, Semide. Santa Maria, livro $\mathrm{n}^{\circ} 1$.

P-Lan, Semide. Santa Maria, livro $\mathrm{n}^{\circ} 2$.

P-Lan, Semide. Santa Maria, maço 8. Livro dos Costumes.

P-Lan, Semide. Santa Maria, maço 10, Diário de 1825-1853.

P-Lan, Semide. Santa Maria, Lembranças/Diário de 1846-1850.

P-Lan, Semide. Santa Maria. Livro de Sacristia, $\mathrm{n}^{\circ} 19, \mathrm{n}^{\circ} 20, \mathrm{n}^{\circ} 21, \mathrm{n}^{\circ} 22$.

Antunes, José Paulo da Costa (1996) «Soli Deo Gloria» Um contributo interdisciplinar para a fundamentação da dimensão musical da liturgia cristã. Porto: Universidade Católica Portuguesa/Fundação Eng ${ }^{\circ}$. António de Almeida.

Assunção, Tomás Lino d' (1900), As Monjas de Semide. Coimbra: França Amado Editor.

Brito, Manuel Carlos de (1983), Vilancicos do Século xVII do Mosteiro de Santa Cruz de Coimbra. Lisboa: FCG (Portugaliae Musica, XLIII). 
Brito, Manuel Carlos de (1989), Estudos de História da Música em Portugal. Lisboa: Editorial Estampa.

Catálogo da Exposição Fábricas de Sons, Instrumentos de Música Europeus dos Séculos XVI $a$ XX. Lisboa: Electa, Museu da Música. Lisboa Capital Europeia da Cultura, 94. Lisboa.

Cerimonial da Congregação dos Monges Negros Da Ordem do Patriarcha S. Bento do Reyno de Portugal. Coimbra: Officinas de Diogo Gomez de Loureyro e de Lourenço Craesbeek, 1647.

Conde, António Linage (1973), Los orígenes del monacato beneditino en la Península Iberica. 3 vols. Leão: Centro de Estudios e Investigación 'San Isidro'.

Constituições da Ordem de S. Bento (1590). Lisboa: António Alvarez, impressor.

Dias, Geraldo J. A. Coelho (1999), "O Mosteiro das Beneditinas de Bragança e as Visitações do Bispo Diocesano”. Actas do Congresso Histórico Páginas da História da Diocese de Bragança-Miranda. Bragança: Comissão de Arte Sacra de Bragança--Miranda, p. 445-468.

Doderer, Gerhard (1996), "A arte Organística em Portugal no Passado e no Presente". Revista da APEM 80 (Lisboa) 3-7.

Doderer, Gerhard (1994), "Instrumentos de tela e corda portugueses dos séculos XVI, XVII e xvIII: clavicórdios, cravos e pianos-fortes”. Catálogo da Exposição Fábricas de Sons, Instrumentos de Música Europeus dos Séculos xVI a Xх. Lisboa: Electa, p. 21-28.

Doderer, Gerhard (1999), "Os Instrumentos de tela e corda em Portugal do Renascimento ao Romantismo", in Arte e Música. Iconografia musical na pintura do séc. $X V$ ao séc. $X X$. Lisboa: Museu da Música, p. 34-41.

Doderer, Gerhard e Van der Meer, John Henry (2005), Cordofones de Tecla Portugueses do Século XVIII: Clavicórdios, Cravos, Pianofortes e Espinetas. Lisboa: FCG.

Fr. Leão de S. Tomás (1974), Benedictina Lusitana, tomos I-II. Notas críticas de José Mattoso. Lisboa: Imprensa Nacional-Casa da Moeda.

Góis, Damião de (1566), Chronica do Felicíssimo Rei Dom Emmanuel. Lisboa.

Gomes, Saúl António (1988), "Documentos medievais de Santa Cruz de Coimbra-I. Arquivo Nacional Torre do Tombo". Estudos Medievais, ${ }^{\circ} 9$.

Horch, Rosemarie Erika (1969), Vilancicos da Colecção Barbosa Machado. Rio de Janeiro: Biblioteca Nacional.

Lessa, Elisa Maia da Silva (1998), Os Beneditinos Portugueses (Séculos XVII a XIX). Centros de Ensino e Prática Musical. 2 vols. Lisboa: Universidade Nova de Lisboa. Tese doutoral.

Lessa, Elisa, (2011) "Vozes do Convento", in Esplendor da austeridade. Mil anos de empreendedorismo das ordens e congregações em Portugal: Arte, Cultura e Solidariedade. Dir. José Eduardo Franco. Lisboa: INCM, p. 587.

Machado, Diogo Barbosa (1759), Bibliotheca Lusitana. Tomos I-IV. Lisboa: Oficina Francisco Luiz Ameno. 
Mattoso, José (1976), "A Introdução da Regra de S. Bento na Península Ibérica”, in Bracara Augusta, vol. XXX (69), p. 97-111.

Mattoso, José (1993), “A Monarquia Feudal”, in História de Portugal. Dir. José Mattoso. Lisboa: Círculo de Leitores, vol. II, p. 64, 68-69.

Melo, Maria Teresa Osório de (1992), O Mosteiro Beneditino de Santa Maria de Semide. Coimbra: Minerva.

Monteiro, Maria do Amparo Carvas (2002), Da Música na Universidade de Coimbra (1537-2002). Coimbra: FLUC. Tese de doutoramento.

Monteiro, Maria do Amparo Carvas (2004), "O órgão da Capela de S. Miguel da Universidade de Coimbra. Identificação do organeiro e de outros artífices e datação do instrumento", in Munda, 47 (Coimbra, Maio, 2004) 3-14.

Nery, Rui Vieira e Castro, Paulo Ferreira de (1999), História da Música (Sínteses da Cultura Portuguesa). Lisboa: Comissariado para a Europália 91/Portugal/IN-CM.

Nery, Rui Vieira (1997), "O Vilancico Português do Séc. xvII. Um fenómeno intercultural", in Portugal e o Mundo. O Encontro de Culturas na Música. Lisboa: Publicações Dom Quixote, p. 91-102.

Neto, Vitor (2007) "Igreja Católica e anticlericalismo, 1858-1910", in Progresso e Religião. A República no Brasil e em Portugal 1889-1910. Coord. Amadeu Carvalho Homem. Armando Malheiro da Silva. Artur César Isaía. Coimbra: Imprensa da Universidade de Coimbra.

Pimenta, Belisário (1958), "As cartas do Infante D. Pedro à Câmara de Coimbra (1429-1448)", in Boletim da Biblioteca da Universidade de Coimbra, ${ }^{\circ}$ XXIII, p. 453-532 (doc. XXI).

Pinho, Ernesto Gonçalves de (1981), Santa Cruz de Coimbra. Centro de Actividade Musical nos Séculos XVI e XVII. Lisboa: FCG.

Smith, Robert C. (1968), Frei Cipriano da Cruz. Escultor de Tibães. Porto: Livraria Civilização.

Stevenson, Robert (1976) Vilancicos Portugueses. Lisboa: FCG (Portugaliae Musica, Série A-XXIX).

Valença, Manuel (1990), A Arte Organística em Portugal (c.1326-1750). Braga: Editorial Franciscana.

Valença, Manuel (1995), A Arte Organística em Portugal - Depois de 1750. Braga: Editorial Franciscana.

Weber, Édith (1982), Le Concile de Trente et la musique. Paris: Honoré Champion. 
Maria Margarida Lopes de Miranda

Centro de Estudos Clássicos e Humanísticos - Universidade de Coimbra

\section{MÚSICA E DANÇA \\ NA TRAGICOMÉDIA DO REI DOM MANUEL, DE ANTÓNIO DE SOUSA (1619)}

\section{Teatro jesuítico em Portugal}

As primeiras obras dramáticas dos Jesuítas em Portugal, nomeadamente em Coimbra e em Évora, inseriam-se não apenas na atividade escolar dos colégios mas também, a outro nível institucional, no âmbito académico superior da própria universidade. Tinham por paradigmas obras de humanistas como Diogo de Teive, Jorge Buchanan e os mestres que precederam os Jesuítas no Colégio das Artes de Coimbra. Por esse motivo, as primeiras peças de teatro são de inspiração profundamente retórica e bíblica, sem deixarem de ser profundamente clássicas e particularmente senequianas.

Não obstante, teatralidade, grandeza e solenidade, riqueza de vestes e profusão decorativa são, desde sempre, uma constante nas descrições de representações escolares do século xvi, diante de uma invariável multidão entusiástica e calorosa.

Veículo da pedagogia humanística e meio de propaganda dos próprios colégios, os espetáculos teatrais eram muito mais do que a ilustração cénica da palavra. Eram concebidos como parte integrante do ensino da Retórica, e deviam por isso obedecer aos preceitos da actio e da pronuntiatio teorizados pelos antigos e retomados pela Retórica de Cipriano Soares de 1562 (sobre as técnicas precisas de voz e de entoação, de expressão de rosto e de movimentos do corpo). As representações teatrais dos jesuítas deviam, além disso, impor-se aos espectadores como verdadeiro espetáculo total, em luxuosos 
aparatos cénicos, com música especialmente composta para a ocasião, numa retórica musical inicialmente subordinada à primazia do texto, de acordo com o que se pensava ter sido a música para o mais autêntico teatro grego. ${ }^{51}$

A participação musical e a intervenção dos Coros dramáticos constitui talvez um dos aspetos mais específicos do teatro dos jesuítas dos primórdios em Portugal, como o próprio Luís da Cruz escreveu no seu prefácio ao leitor (Cruz 1989: 25) e como já tive oportunidade de afirmar em outros estudos (Miranda 2003). ${ }^{52}$ Da tradição humanística de Coimbra, foram pioneiros e ficaram célebres os Coros dramáticos de Diogo de Teive, que celebravam a vitória de David sobre Golias (1550), bem como os Coros da Tragédia de Acab de Miguel Venegas (1562) e da Sedecias de Luís da Cruz (1570). Estes últimos, compostos por D. Francisco de Santa Maria (Pedro Miranda 2005: 131 ss.) e cujos Ms. se conservam parcialmente, têm a originalidade de constituir o mais antigo exemplar conhecido de música para o teatro humanístico.

A intenção originária de revitalização dos modelos greco-latinos e a obrigatoriedade da língua neolatina davam ao espetáculo jesuítico uma feição marcadamente visual, que atraía não só aqueles que tinham capacidade para compreender as longas récitas, mas também os populares que, no dia das representações, enchiam o pátio do colégio. A representação dramática que será objecto deste estudo é, portanto, o culminar de uma tradição longamente estabelecida no nosso país.

\section{A Tragicomédia do Rei Dom Manuel (1619)}

Uma das mais notáveis e mais conhecidas representações jesuíticas de sempre foi a que se realizou em 1619, no Colégio de Santo Antão, em Lisboa,

51 Graças ao Centro de Estudos Clássicos e Humanísticos da Universidade de Coimbra, algumas dessas composições ainda inéditas e conservadas na Biblioteca Geral da Universidade de Coimbra foram já executadas em recital e registadas pelo Grupo Vocal Ançã-ble, no CD Retórica Musical e Música Retórica apenso ao volume Retórica e Teatro: A palavra em acção Porto, 2010, nomeadamente alguns Coros dramáticos por ora considerados os mais antigos do género musical dramático na Europa (séc. xvi). A esse respeito vd. Pedro Miranda (2005) e Margarida Miranda 2006: 299-332.

52 Muitos são os motivos que unem o drama jesuítico ao melodrama. Vd. Morelli e Sala 1994. 
para receber a visita de Filipe III de Espanha a Portugal: a Tragicomédia do Rei Dom Manuel, ou Tragicomédia da Descoberta e Conquista do Oriente, do jesuíta António de Sousa (Mimoso 1620). Tudo foi composto e preparado em menos de 25 dias, diz o prefácio de Sardinha Mimoso, autor do relato mais completo (latino curiosoque lectori): desde o plano inicial até à composição do texto, seguida da distribuição dos papéis aos actores e aos músicos. Mesmo assim, a representação estendeu-se ao longo de dois dias e foi considerada sem rival em qualquer corte europeia. Foi um dos momentos mais altos do programa festivo que celebrou a primeira visita régia à capital lusa sob o domínio filipino, cujos acontecimentos foram encomiasticamente relatados por mais de trinta autores (Alves, 1986: 50-67 e Alenda, 1903: 193-202).

A visita, contra o parecer do Conselho do Estado e do Conselho de Castela, dava-se trinta e cinco anos depois de o monarca ter sido investido como herdeiro do trono de Portugal. Ora, uma das petições que os portugueses acalentavam consistia em tornar Lisboa capital do reino lusoespanhol. O acolhimento ao Monarca deveria pois demonstrar a dignidade de uma grande metrópole, demonstrar o poder e a riqueza de uma grande nação que era a rainha da Europa, protagonista de uma história heroica sem precedentes. Assim se explica a escolha do tema da Tragicomédia e o tom de exaltação patriótica, inspirada na história pátria e nas descobertas e conquistas do Oriente.

Embora não houvesse então uma Corte em Portugal, a Tragicomédia do Rei Dom Manuel era concebida à semelhança dos espetáculos de Corte europeus, e parecia ser o non plus ultra de uma já longa tradição de sumptuosidade e grandeza que caracterizava os palcos jesuíticos portugueses. Nela figuravam mais de 300 personagens, com um guarda-roupa de uma riqueza oriental deslumbrante, carregado de pedras preciosas: mil e noventa diamantes, três mil pérolas, duzentas e quarenta e oito esmeraldas, mil cento e trinta e nove rubis, antigos brocados históricos, sedas raras e adereços preciosos emprestados pelas casas mais fidalgas, pelas igrejas e pelos mosteiros. Duas mil e oitocentas pedras adornavam a figura alegórica de Lisboa e duas mil duzentas e cinquenta, a Alegoria da Piedade. Até uma espada que pertencera a D. João II viera dar maior dignidade à representação. A cenografia e a 
coreografia eram magníficas e a complicação da maquinaria excedia tudo o que até então se havia visto. ${ }^{53}$

À amplificação do espetáculo associaram-se não só a recitação e a dança, mas também as artes plásticas, a arquitetura, o canto e a música, para produzir aquilo a que hoje chamaríamos um espetáculo total, como só uma imaginação barroca poderia conceber.

\section{Prólogo e Ato I}

Música instrumental foi o que deu início ao espetáculo propriamente dito, no dia 21 de Agosto de 1619. Quando a família real chegou ao Colégio e tomou assento, houve um alegre aplauso entre os circunstantes, con salva de musica de chirimias y atabales y, sossegado o auditório, se empeço la obra.

Assim, aliás, fora o rei saudado, à chegada ao cais da cidade: além dos músicos que acompanhavam o monarca na própria galera real sumptuosamente decorada, havia barcos músicos igualmente decorados; e os momentos musicais sucederam-se ao longo do cortejo pela cidade, nas cerimónias da Sé e na Rua Nova - sobre o Arco das Fangas da Farinha, utilizado como palco de teatro para que um grupo de cantores, vestidos de canteiros, se exibisse diante do séquito real.

Mas voltemos ao drama. Depois de um Prólogo repartido entre Lisboa, Sintra e o Tejo para dedicar o espetáculo ao Rei e apresentar o tema da tragicomédia, é novamente ao som de música instrumental (de acordados menestriles y atabales) que as personagens se retiram, para dar início ao Ato I (fol. 9).

Apesar da divisão em cinco Atos, não é simples fazer a narrativa da acção dramática, rarefeita que se encontra numa sucessão de quadros alegóricos e de quadros históricos, que suspendem continuamente as fronteiras do real

53 À fonte mais completa que é Sardinha Mimoso (1620), podemos hoje acrescentar alguns comentários mais recentes à representação, feitos por Dietrich Briesemeister (2006), Miranda (2006) e Pires (2010). Sob um ponto de vista mais indireto, centrado sobretudo na entrada régia mas incluindo também a obra dramática de António de Sousa, refira-se também o estudo de Marica Benatti (2008). 
e do onírico para surpreender todos os sentidos do espectador e o arrebatar numa sequência interminável de sugestões e fantasias.

Há, no entanto, um fio condutor responsável pelo conflito, que atravessa toda a representação. Mais do que histórica, a matéria da tragicomédia é mitificação da história. Por isso, vemos personagens alegóricas, como o Culto Divino e a Idolatria, alternarem em cena juntamente com personagens históricas. A Idolatria e seus sequazes conspiram contra os Portugueses e contra a sua missão de difundir o Culto Divino. É esse plano simbólico que move os acontecimentos, dando assim à história portuguesa uma interpretação providencialista. De um lado o Culto Divino, a Fé e a Piedade, de quem são aliados Dom Manuel e os Portugueses; do outro a Idolatria, a Perfídia e a Cegueira, servidas pelos gentios e as forças da Natureza. Assim, o Rei Dom Manuel e os Portugueses foram os eleitos de Deus para levar a Fé ao Oriente, mas têm que enfrentar a oposição dos deuses vãos, da Perfídia e da Cegueira, que conspiram contra eles, com o auxílio da própria Natureza e dos seus elementos.

Peça dramática tipicamente barroca, a Tragicomédia de Dom Manuel não estava sujeita à precisão dos cânones literários aristotélicos. Podia incorporar reis e heróis mas também alegorias e divindades clássicas, diabinhos e personificações dos elementos da Natureza, personagens de estatuto elevado ou humildes pastores, índios e negros, dando lugar à maior profusão de tons, de estilos de cenários.

Saudado o Monarca e o seu séquito, e dedicado o espetáculo a Sua Majestade, no Prólogo, tem início o Ato I, desde logo com uma notável pluralidade de espaços e de cenários, como descreve Sardinha Mimoso no início da sua $R e$ laçam (fol.3). Num proscénio construído à semelhança dos edifícios teatrais romanos e decorado com colunas, cornijas, frisos e arquitraves revestidos de damascos às cores, havia duas portas: do lado direito entrava e saía o Rei Dom Manuel e todas as personagens que diziam respeito a Portugal; do lado esquerdo, os Mouros e tudo quanto dissesse respeito aos gentios. No nível superior daquela fachada arquitetónica, estava representada a Glória celeste e a hierarquia divina. Dali descia o Anjo da Guarda do Oriente, no meio de uma nuvem formosa; além das duas portas semelhantes às do proscénio antigo, havia ainda dois nichos: um, à direita, continha o trono e o palácio de Éolo, rei dos ventos, de onde haveriam de sair os quatro ventos; outro nicho, 
à esquerda, representava uma boca de Inferno que ora abria ora fechava, vomitando demónios.

Este cenário encontrava o seu paralelo (ou simetria) num grande resplendor de ouro que fingia ser a abertura do céu, por entre um espaço de nuvens e de estrelas delimitado por treze Anjos ao vivo, vestidos de sedas e brocados às cores, com cabeleiras ruivas, grinaldas de flores e instrumentos musicais nas mãos. Este requintado quadro celeste permanecia, porém, oculto por uma espécie de cortinado que era descerrado para revelar subitamente a formosura do espetáculo. E só então os Anjos tocavam os instrumentos que tinham nas mãos. A série de instrumentos que o cronista identifica (começando nos sopros, continuando nas cordas de arco e terminando de novo nos sopros) são um sinal evidente da grande variedade de timbres conjugados e do brilho intencional das peças escutadas: dos baxones, dos violones de arco, dos rabequillas, dos flautas, y otros vários instrumentos músicos (fol. 3).

Não era aleatório o momento em que se descerrava o esplendor da Glória para revelar os Anjos musicantes. Pelo contrário, ele constitui uma das cenas mais emblemáticas da peça. Quando as três alegorias cristãs, o Culto Divino, a Fé e a Piedade, lamentam os estragos feitos no mundo pela Idolatria, abre-se o Céu, correndo as cortinas da representação da Glória, para enviar à Terra o Anjo da Guarda do Oriente. Este desce num pequeno estrado coberto por uma nuvem, por entre os Anjos da corte celestial, ao som da música de variados instrumentos, trazendo na mão uma esfera dourada. Desce até meio da fachada para anunciar ao Culto Divino que em breve será Senhor de todo o Oriente, pois Deus escolheu D. Manuel para essa missão. Depois, desce ainda mais para depor a esfera nas mãos do Culto Divino, o qual por sua vez a entregará nas mãos de Dom Manuel, e retira-se de novo sobre a nuvem em direção ao Paraíso, ao som da mesma música que o havia trazido à terra.

Determinados os acontecimentos pelos desígnios divinos, o Ato I consiste na preparação da viagem ao Oriente - motivada em Dom Manuel por um sonho que ele reconhece ser de inspiração divina. Ao descerrar da Glória com a música dos Anjos celestes sucede simetricamente o rasgar-se dos Infernos, vomitando demónios, dragões e serpentes no palco, por entre nuvens de fogo e fumo negro, acompanhado não já de música mas de um enorme estrondo. 
A missão é então confiada a Vasco da Gama. Enfurecem-se os Infernos, mas os Portugueses rejubilam e representam a primeira folia do drama: às ordens do Tejo, junto de Lisboa e da Serra de Sintra sale una dança de treze pastores de su ribera (...) Dançaron alo pastoril lindamente al sonido de flautas, desafiandose entre si a qual dançava mejor. A primeira dança do drama representa portanto um momento festivo popular de alegria pastoril, encenando uma dança de pastores ao desafio, ao som de flautas.

Por fim, regressa à cena Vasco da Gama, reunindo o piloto e os marinheiros e encorajando-os para a partida. O Ato I termina então com a partida dos Portugueses rumo ao Mar, com uma nau da Índia em palco (de mais de trinta palmos), guarnecida com a cordoaria e equipamento necessários (incluindo a artilharia, cujos disparos ao vivo saudaram o rei). Ouve-se grande gritaria e vozes de marinheiros e é então que um duplo Coro assinala o final do Ato I, dialogando com Vasco da Gama enquanto este navega mar adentro: um Coro de Marinheiros dentro da nau, cantava em português, celebrando a virtude lusitana em versos de quatro sílabas: Fortes Portugueses / Conquistai o mar / Que a terra é pequena / pera triunfar! O seu canto alternava com o canto latino de um outro Coro, constituído por cinco Tritões e quatro Sereias, que permanecia em volta da nau, sobre as ondas encrespadas de um mar que a imaginação do cenógrafo também simulou. Um dos Tritões acompanhava o canto com uma harpa suspensa sobre o mar, outros tocavam baixão (baxon, fol.27) $)^{54}$, enquanto os restantes faziam ouvir a sua voz cantando primeiro 13 , depois 20, depois 25 versos latinos, alternados com o canto dos Marinheiros. Se as intervenções de Vasco da Gama parecem dirigir o canto dos Tritões, o canto dos Marinheiros, em versos extremamente curtos, mais parece concebido ao modo de canto de faina, nomeadamente canto de barqueiros (destinado a ritmar a ação conjunta de remar), que o cronista, na respetiva didascália, designa por celeuma (fol. 28): Exit chorus Trytonum et Sirenum, quem ducit / Gamma naui Indica uectus. / Trytonum cantibus admiscetur Nauticum, Celeuma (Sai um Coro de Tritões e de Sereias, conduzido por Gama numa nau da Índia. Ao canto dos Tritões acrescenta-se um canto de marinheiros, celeuma).

\footnotetext{
54 Na tradição portuguesa, o Baixão refere-se a um instrumento de sopro, de palheta dupla, da família das charamelas, antepassado do fagote. Vd. Alvarenga 1994:112.
} 


\section{Ato II}

No Ato II representa-se a conspiração dos elementos da Natureza contra os navegantes portugueses, com o auxílio do Oceano, aliado da Idolatria.

A Terra, o Ar, a Água e o Fogo, magnificamente caracterizados, tanto quanto uma imaginação barroca servida pelos melhores recursos técnicos podia conceber, escutam a indignação do Oceano, e cada um parte a convocar os seus sequazes contra as naus dos Portugueses, enquanto a Idolatria e suas companheiras exprimem em palco a raiva e a fúria que sempre as caracterizam (fol. 35). Com a Terra, vêm os Promontórios, entre os quais o Cabo da Boa Esperança; com a Água, majestosamente sentada sobre uma orca que lança água e peixes vivos, vêm os monstros marinhos; ao lado do Ar e de Iris, apresentam-se Éolo e os restantes ventos, vindos do seu palácio; e com o Fogo vem o Raio, as Chamas, o Relâmpago e os Cometas. Certas da sua vitória, as forças da Natureza unem-se então para executar uma dança, a dança dos quatro elementos com seus servos, a sugerir a dança dos astros no orbe terrestre (fol. 40 e 42). De poderoso efeito cénico, nela sobressaía de modo particular a caracterização exterior das figuras, o artifício e variedade surpreendente dos trajes, fiéis à iconografia clássica descrita pelos poetas. ${ }^{55}$ Fue dança sobre manera artificiosa, por los enredos com que tan diuersos trajes y formas de monstros al mismo compas dançavan, sin perder punto unos perante los otros (fol. 40).

Depois da dança dos Elementos, de enorme poder simbólico, retiram-se as personagens e o argumento regressa ao plano real e humano: é a vez de impressionar os ouvidos com a gritaria de marinheiros e o grande estrondo da tempestade que as forças cósmicas fizeram abater sobre os portugueses. Sobe então ao palco um Marinheiro para relatar ao próprio Rei os grandes trabalhos e tempestades com que Vasco da Gama conseguiu enfim atravessar o Cabo da Boa Esperança e prosseguir viagem.

\footnotetext{
55 Tritão e o Oceano guardam semelhanças evidentes com as figuras representadas por Camões nos Lusíadas (VI, 16-17), inclusivamente quanto aos termos da descrição, mas é o próprio Sardinha Mimoso que regista essa semelhança, quando descreve o Oceano rei das águas, tal le fingen los poetas; e Tritão como el poeta Camões le pinta mancebo grande y feo Trompeta de su padre y su correo (Fol. 31).
} 
De novo no plano divino, a Idolatria e as forças demoníacas derrotadas lamentam-se do seu insucesso e preparam novos assaltos aos portugueses.

O Coro II, totalmente em língua latina, é executado por uma personagem sem rosto que aclama os êxitos dos portugueses ao vencerem as forças da Natureza. Tem porém a particularidade de dialogar com a Idolatria e com cada um dos Quatro Elementos - solistas - que lamentam o fracasso dos seus planos.

\section{Ato III e entremez}

Quando a raridade dos diálogos e o enfraquecimento da acção dão lugar a uma maior procura de espetacularidade, ganham os Coros e as danças maior incidência. É o que acontece no Ato III e no Ato V, de conteúdo inteiramente celebrativo, em que os Coros e as danças ganham uma dimensão mais relevante.

Se no Ato I, os pastores do Tejo tinham celebrado com danças a partida de Vasco da Gama para a Índia, no Ato III são os pastores de Sintra que celebram a sua chegada, com folias de sus músicos serranos (fol. 49). Nove moços galhardos, um com seu tambor, os outros com sistros e guizos (cestros y sonajas), dançavam e cantavam alternadamente (a la camponês, acrescenta o cronista): No mundo que descubristes / Gama, luz de Portugal/ Dizei se vistes / Rei tan venturoso / ou vassalo tão leal. Vasco da Gama apresenta-se então diante de Dom Manuel, trazendo-lhe em desfile o Oriente com as Províncias conquistadas, e o Monarca ordena que se celebrem festas públicas. Àquele primeiro momento de festa popular ingénua e pueril, em que os jovens pastores proclamavam em ambiente de folia, Manuel he sem segundo, segue-se então uma outra dança mais grave e mais vistosa: a dança do Oriente com suas quinze Províncias sumptuosamente representadas, cada uma com suas insígnias e atributos (fol. 50 ss.): Malabar, Arábia, Pérsia, Cambaia, Decão, Bengala, Pegu, Malaca, Samatra, Sião, China, Japão, Maluco, Etiópia e Ceilão.

O Coro chefiado pelo Oriente constitui pois o primeiro Coro do Ato III, entendido como Coro de bailarinos: Ducit chorum Oriens suarum Prouinciarum (fol. 57). Sardinha Mimoso nada diz sobre a música desta dança solene, 
referindo-se apenas brevemente à sua coreografia (fol. 52) que designa por dança da morte real, com as Províncias dispostas em três fileiras, erguendo ao alto os seus atributos umas para as outras. O autor do relato parece, no entanto, aludir a um modelo coreográfico já criado, inspirado na alegoria secular da universalidade da morte, adequado aliás ao desfile de diferentes figuras, como era efetivamente a série de Províncias do Oriente. Certo é, no entanto, que o teatro jesuítico já possuía então uma notável tradição coreográfica. Alguns anos antes, em Nápoles, 1603 e 1604, na representação da Tragédia Crispus, de Bernardino Stefonio, um Coro de bailarinos desenhara uma águia bicéfala, um caduceu e um labirinto, intersectado com uma cruz (Strappini e Trenti, 1998).

Retirando-se Vasco da Gama, ainda no Ato III, recebe Dom Manuel a notícia inesperada da descoberta do Brasil, que vem conferir aos festejos um quadro mais vivo e gracioso para dar lugar a um dos momentos mais singulares do drama: o segundo Coro do Ato III, ou Coro Brasílico. Eis que o Brasil faz sua entrada, montado num crocodilo e ladeado por seis papagaios representados para o efeito, além de um séquito de índios (tapuias e aimorés). Reflexo evidente da curiosidade natural que o continente americano ainda despertava na Europa, os povos índios parecem merecer do jesuíta uma outra simpatia, mais cândida e mais pueril. Um chefe índio acompanhado de doze tapuias e aimorés simulam a nudez por meio de uma veste justa de cor parda. Trazem o corpo e a cabeça enfeitados de penas coloridas e, nas mãos, arco e flechas, baylando y parlando a su modo ao som de maracas feitas de cabaças cheias com pedrinhas. Dançam em círculos e com grande estrondo de pés (fol. 58). Interpelado pela curiosidade do Rei Dom Manuel, o chefe índio diz aos seus que façam uma demonstração das suas artes, dancem e toquem a seu modo. E começa ele mesmo a cantar a solo, acompanhado à viola, no português estropiado que dissera ter aprendido (en la musica y lenguage que ele mismo compuso a su arte), ao que os outros lhe responderam em coro.

Terminado aquele canto, o Coro Brasílico executa ainda nova dança, sempre em círculo, ao ritmo das maracas que o chefe índio dirigia, colocado no centro, enquanto cantava os versos em língua brasílica que sardinha Mimoso transcreveu, lado a lado com a respetiva tradução. Quer na composição do coro brasílico quer nesta, em forma de crioulo, são evidentes as semelhanças 
formais e semânticas destas composições com os tradicionais vilancicos de Natal, de natureza popular. $\mathrm{Na}$ verdade, os índios em palco parecem saudar a presença do rei como quem, nos cantos tradicionais, saudava o Menino Jesus.

Acabado el choro Brasilico se seguia el Latino por no acabar el acto menos graue... (fol. 60). Novo Coro Latino, executado pela mesma personagem sem rosto, põe fim ao Ato III, com um hino a celebrar mais uma vez a coragem dos portugueses.

A primeira jornada da representação que agora termina previa, porém, uma espécie de entremez. Este, se bem que formalmente distinto do drama cuja representação interrompia, era constituído por cantos e danças, dedicados a Filipe III de Espanha pelas mesmas personagens que haviam feito parte do drama: dez foliões cantando em português, com guizos, tambores e pandeiros, saudavam a presença do rei e do séquito real, no meio de grandes acrobacias (fol. 61); vendo que gente blanca salia a hazer fiesta, o Coro Brasílico começa uma nova dança extremamente viva, ao som de um cortiço em forma de tambor. Cantam em português e em tupi, um canto repartido entre os tapuias com seu chefe e os próprios Papagaios (fol. 61-62). Terminada esta exibição, Brancos e Negros executam um Coro duplo: ao Coro dos Brancos, em português, respondem os tapuias em crioulo, com uma música contrafeita (fol. 62) cujas origens o cronista não identifica.

\section{Ato IV}

A representação continua na tarde do segundo dia, com nova oposição ao projeto dos Portugueses - oposição não já situada no plano simbólico, mas no plano histórico. No Ato IV, o Sultão do Cairo ameaça os portugueses com as armas e chama à sua presença o eremita Frei Mauro, para fazer dele embaixador junto do Papa, a fim de que o Sumo Pontífice, temendo as represálias anunciadas, ordene aos portugueses a retirada do Oriente. Frei Mauro vem então à presença de Dom Manuel para lhe comunicar as terríveis ameaças do Sultão, enquanto na Índia, o vice-rei D. Francisco de Almeida enfrenta o exército inimigo, naquela que ficou conhecida como a batalha de Diu (3 de Fevereiro de 1509), representada no palco de Santo Antão. Derrotado, porém, 
o inimigo não desarma; prepara nova emboscada, serve-se da feitiçaria e convoca a Incúria e os demónios do Inferno. Assim se anunciam as dificuldades sofridas pelos Portugueses na viagem de regresso, bem como a morte do Vice-Rei, como forma de compensar o Sultão pela derrota sofrida. E o Ato IV termina com o Coro e cortejo fúnebre de Dom Francisco de Almeida e a sua chegada ao Reino da Glória, onde S. Tomé, padroeiro da Índia, proclama Afonso de Albuquerque sucessor de Francisco de Almeida e o convida à alegria, pois ele continuará a missão de expandir o Culto Divino no Oriente.

O Coro final do Acto IV (fol. 83-85) inscreve-se assim na tradição de Coros fúnebres que, desde as primeiras representações de Miguel Venegas, em Coimbra e no Colégio Germânico, terminavam as representações jesuíticas. ${ }^{56}$ Ducit Pietas Chorum funebrem... O Coro fúnebre de D. Francisco de Almeida, em diálogo com a Piedade, a Fé e o Culto Divino, choram a morte do herói português, até ao momento em que os Céus se abrem de novo e São Tomé anuncia o seu sucessor. Por fim, o Coro fúnebre converte-se num breve Chorus festiuus (fol. 85), que os soldados assinalam com grande salva de trompetas, chirimias y mas instrumentos de fiesta.

\section{Ato $V$ e triunfo final}

Finalmente, no Ato V, assistimos à chegada de uma nau vinda do Oriente, carregada de produtos exóticos, especiarias e diversas riquezas. A nau é recebida pela alegoria de Portugal, enquanto os capitães de D. Francisco de Almeida anunciam ao rei a vitória em Diu. Mas logo de seguida a 'ação' desloca-se de novo para Oriente, para evocar as vitórias do segundo Vice-Rei da Índia.

Como no início do drama, os acontecimentos são expostos a dois níveis: os acontecimentos simbólicos e prodigiosos vêm como que antecipar os feitos históricos dos portugueses e inseri-los numa história providencialista. A Ásia, montada num rinoceronte, comenta com os Rios Indes e Ganges um sonho misterioso segundo o qual um capitão estrangeiro lhe prometera

\footnotetext{
56 Os Coros fúnebres de Miguel Venegas, por sua vez, eram tributários de Diogo de Teive, que precedeu os Jesuítas no Colégio das Artes (Soares, 2010).
} 
libertá-la do jugo maometano. Reconhecendo em Afonso de Albuquerque a figura misteriosa do seu sonho, a Ásia joelha-se a seus pés suplicante. Apesar do retraimento dos seus soldados, o capitão decide travar guerra com Ormuz, e é então que o seu desígnio recebe a confirmação sobrenatural, por meio da visão de uma cruz adorada por uma multidão de Anjos.

Na Tragicomédia de António de Sousa, a batalha de Ormuz surge, portanto, como resposta à súplica da Ásia para ser libertada do domínio maometano. Súplicas semelhantes são endereçadas por Goa e por Malaca, até que Afonso de Albuquerque é de novo recebido em palco, como Senhor do domínio português no Oriente. Em nome do Rei Dom Manuel, manda então erguer uma fortaleza e sobre ela manda colocar uma pedra onde são inscritos os nomes dos heróis portugueses. E a peça termina com um cortejo de triunfo, em que Afonso de Albuquerque entrega a Portugal os reinos conquistados.

Seja como linguagem celebrativa, seja como meio de entretenimento, é no Ato V que a música ganha maior predominância. Quando a nau do Oriente chega por entre as ondas, carregada de fardos canela e de pimenta e outras mercadorias da Índia, os marinheiros vêm cantando, como cantando haviam partido, rumo ao mar, no Ato I. Mas o momento mais relevante é aquele em que a Glória se abre de novo para uma visão sobrenatural, não para enviar o Anjo, mas para mostrar ao Vice-Rei a cruz do próprio Cristo, iluminada por grande resplendor e cercada por uma multidão de Anjos em adoração. A aparição, descrita no fol. 90, consiste na Cruz em movimento, descendo das alturas numa peanha de nuvens, coberta de Serafins, três dos quais simulavam sustentá-la com as suas próprias asas. Desciam-na primeiro e depois erguiam-na pelos ares, para a recolherem por fim na Glória, que logo se encerrava, diante do olhar atónito de Afonso de Albuquerque e os seus setenta soldados, prostrados em terra para adorarem o lenho sagrado. Auditur caelestis concentus et rupta nube apparet Crux. É ao som de música celestial que se abrem os céus para revelar a cruz da Glória, e é ao som da mesma música celestial que eles se encerram, para confirmar a decisão do Vice-Rei. Seria aquele caelestis concentus música instrumental ou música vocal? Ou seriam antes ambas as expressões? O relato de Sardinha Mimoso nada mais acrescenta sobre a música que acompanhou a segunda manifestação da Glória, mas o leitor conserva ainda na memória a descrição do Acto I, 
quando os Céus se abriram pela primeira vez na fachada arquitetónica do proscénio para que o Anjo da Guarda do Oriente descesse a entregar a esfera ao Culto Divino. Foi uma pequena orquestra de Anjos que então se fez ouvir e que incluía, além das tradicionais flautas e outros instrumentos, um conjunto de instrumentos que ia desde os timbres mais graves aos mais agudos: baxones, violones de arco, rabequillas, flautas y otros (fol. 3). O paralelismo de cenas e de maquinismos cénicos implicados permite pensar que seriam formas musicais semelhantes as que apareciam associadas ao mundo celeste, e em ambas a música instrumental parece ser intencionalmente brilhante, tendo alcançado total autonomia.

Depois deste quadro sobrenatural, ficam em cena o jovem Ceifadino, rei de Ormuz, com o seu séquito de dezasseis pajens, e Coieatar, seu tirânico Governador e Conselheiro. Mas a presença dos dois gentios é apenas o pretexto para representar uma nova dança. O Governador parte para a guerra e deixa o pequeno Ceifadino (de doze anos apenas) na companhia dos meninos pajens da mesma idade. Agitant choream Aulici, dum saltant, lê-se no fol. 97. A dança que os pajens de Ormuz executam com seu rei é uma dança exótica e pueril, mas tem características militares de matriz oriental, como demonstra o uso dos instrumentos de guerra: os pajens desembainham catanas e movem-se em forma de guerra, dançando a punto (expressão com que por diversas vezes designa a cadência) e recolhendo-se debaixo dos escudos, descreve Sardinha Mimoso (fol. 96)

Luego hazen sus juegos y danças a la manera de su pátria, sacando a compas las catanas de sus vaynas y haziendo alegres mudanças, en forma de guerra, lo qual hazian com lindo ayre, y gracia, saltando a punto, y recogiendose debajo sus escudos (fol. 96).

O bailado, de cuja música também nada se diz, termina ao som das trombetas portuguesas que já anunciavam a batalha. Fazendo muralha com as suas catanas e escudos, os pajens rodeiam então o jovem Ceifadino e todos se retiram do palco.

Depois de representar em cena o cerco à cidade (fol. 98), a luta corpo a corpo de mais de sessenta soldados ao som de trombetas e tambores, sob o 
estrondo de verdadeiros projéteis, no meio do verdadeiro odor da pólvora e com disparos de artilharia contra a muralha (o proscenium), o episódio termina com o preito de vassalagem do próprio rei Ceifadino - expulso o seu tirânico governador - ao rei Dom Manuel, seguido da conquista das cidades de Goa e Malaca, conforme estas haviam pedido. O exército português abre mesmo uma brecha na muralha, e nela ergue a bandeira da paz (fol. 102: displodit fistulam Lusitanus, in muro pacis uexillum erigitur).

Se estivéssemos num drama de argumento, a vitória de Afonso de Albuquerque preencheria de imediato a cena final do drama, mas o espetáculo não prossegue sem outro momento musical igualmente integrada no drama: o Coro dos Canteiros (Lapicidae), que Sardinha Mimoso descreve no fol. 107 - 109: Lapicidae canentes marmor expoliunt (fol. 108).

Com los escopros, cinzeles y picos, hazian en la piedra agradable sonido a compas que les servia de instrumento acordado a que cantavan la letrilla que va abaxo, dando muchas bueltas al rededor, y haziendo agradables mudanças al son de su musica (fol. 107).

Os termos da descrição sugerem mais um canto de faina, dirigido pelo bater das próprias alfaias na pedra. Os Canteiros a quem Afonso de Albuquerque manda esculpir os nomes dos heróis portugueses fazem-no cantando redondilhas menores (fol. 109), ao ritmo do seu próprio escopro e cinzel, em movimentos de dança, repetindo o estribilho Porque nos cansamos / em pedra lavrar.

Terminada esta cena, encaminha-se o espetáculo para o seu final, com o triunfo de todas as personagens, organizado em dois cortejos e não um. O primeiro cortejo corresponde ao plano histórico e às personagens humanas; o segundo refere-se ao plano sobrenatural da ação e às personagens divinas. Como num triunfo romano, à frente do exército vêm os prisioneiros de guerra. Segue-se o Tejo, com os seus pastores, e a serra de Sintra com os seus foliões, todos em alegre festa. Depois vem a nau da Índia, cercada de Sereias e Tritões, cantando a choros com os marinheiros. À frente do Oriente ia o cortejo das quinze Províncias, que repetiu a sua famosa dança com os seus atributos (cena XVI), e o mesmo fez o jovem Ceifadino, com seus pajens 
vestidos à mourisca. Juntaram-se-lhes os Canteiros de Afonso de Albuquerque, cantando os louvores de Portugal ao som dos seus instrumentos, e por fim o Brasil:

No quiso el Brasil quedarse fuera del alegre y magnifico triunfo, y sentado en su crocodilo, truxo sus Tapuias y Aymores, com los papagayos en medio, y detrás el Capitan que truxo la nueva del Brasil descubierto (fol. 113).

Como anteriormente, no Ato III, a entrada dos Índios do Brasil no cortejo é representada na sua mais autêntica espontaneidade. É por sua própria iniciativa que se associam, como expressão da inocência e pureza que o dramaturgo lhes atribui. Após eles, seguiam os Capitães portugueses do Oriente, Vasco da Gama, Francisco de Almeida e Afonso de Albuquerque, com coroas de louro como os vencedores Antigos, para entregar a Portugal todos os Reinos e Províncias do Oriente conquistados.

Após este primeiro cortejo histórico, um segundo cortejo traz à cena as figuras alegóricas do drama para representarem a apoteose de Portugal sobre um carro triunfal. Diante do Monarca visitante (Filipe III de Espanha) desfila Portugal em seu carro, puxado por um elefante, um rinoceronte, um tigre e um leão. Com a Ásia por cocheiro, também Portugal trazia os seus simbólicos prisioneiros: a Idolatria, a Cegueira, a Perfídia e os demónios, juntamente com as figuras dos Elementos que haviam conspirado contra os portugueses, os sequazes do fogo e da Água, os monstros marinhos, os Promontórios, os feiticeiros e os sacerdotes pagãos, e até os animais terríficos aludidos no drama (o cão Cerbero, a Salamandra e as Águias). Enquanto os elementos do primeiro cortejo, histórico, soltavam vivas e aclamações ao som da música de instrumentos, todos estes seres alegóricos, por seu lado, faziam ouvir apenas os seus lamentos, gemidos e tristes vozes.

Chegando então Portugal junto de Sua Majestade (Filipe III de Espanha), desce do seu carro triunfal e oferece-lhe as vitórias de seus filhos. Depõe a coroa que levava na cabeça e entrega-lhe os ceptros que levava na mão (em sinal dos cinquenta e sete Reinos do Oriente), com o pedido de que leve adiante aquilo que seus avós tão prosperamente começaram (fol. 114). Não é 
demais realçar a riqueza simbólica de um gesto como este. A ironia histórica é evidente, sobretudo se tivermos em conta o abandono a que ficaram sujeitos os territórios portugueses de além-mar, expostos à cobiça de holandeses e franceses durante o domínio filipino, sob o olhar indiferente da coroa.

O triunfo final estende-se ao longo das cinco últimas cenas (XIV a XVIII), para que cada pequeno coro faça de novo a sua entrada, até que em palco ficam apenas Portugal e o seu império (Ásia, Goa e o Rei de Ormuz, o Brasil e os Índios) dialogando em verso com um Coro Triunfal que eleva o sentido da história de Portugal ao afirmar que a nação recusa o triunfo mortal em nome do divino, mais digno de louvor (mortalem renuens quaeret Olympicum / Laude triumphum).

\section{Conclusão}

Do ponto de vista da realização do espetáculo, a profusão de pedras e tecidos preciosos (pérolas, esmeraldas, rubis, brocados históricos) e outros raros adereços, na caracterização das personagens, corresponde à variedade e omnipresença da música e da dança, desde a conceção original. Por outro lado, a diversidade de géneros musicais acompanha naturalmente a diversidade de ambientes recriados: a música celestial dos Anjos do Paraíso, a vozearia dos marinheiros remadores, o canto sereno dos canteiros ao som de escopros e cinzéis, o canto fantástico de Sereias e Tritões, o canto rude de tapuias, aimorés e papagaios, o canto espontâneo e simples dos pastores, a música exótica dos pajens de Ormuz, o canto fúnebre por D. Francisco de Almeida e o canto celebrativo das glórias dos portugueses.

Ao contrário da teoria dramática de Luís da Cruz que, fiel à maneira Antiga, recomendava que o Coro representasse uma personagem (coletiva), o Coro na Tragicomédia do Rei Dom Manuel encarna múltiplas personagens e assume papéis tão diversificados como fragmentários. Outras vezes, precisamente no lugar canónico do Coro (no final de cada Ato), este parece não corresponder a personagem alguma, sendo executado por uma personagem sem rosto que dialoga com determinadas personagens do drama. Se o final do Ato I é preenchido por um duplo Coro bilingue (um de Tritões e Sereias e 
outro de Marinheiros), os Coros do final do Ato II e III parecem não pertencer ao drama e limitam-se a cantar, em versos latinos, os feitos dos portugueses. $\mathrm{O}$ mesmo acontece com o Coro triunfal do Ato $\mathrm{V}$, que dialoga versos latinos com a Ásia, Goa, o Rei de Ormuz, o Brasil e os Índios. Só o Coro do Ato IV, correspondendo ao cortejo fúnebre de D. Francisco de Almeida, pode ser vagamente identificado com os soldados portugueses, como acontecia com outros Coros semelhantes da tradição dramática jesuítica - mas nada mais é dito a esse respeito.

Na verdade, no espetáculo barroco, os Coros finais não têm a importância dramática que Luís da Cruz lhes atribuía, quando escrevia o seu prólogo ao leitor. Na Tragicomédia do Rei Dom Manuel, eles diluem-se num conjunto de momentos musicais de muito maior efeito, quando associados à complexidade das coreografias e da cenografia, como é o caso do Coro de Tritões e de Sereias ou do Coro dos Marinheiros durante a navegação da nau da Índia sobre as ondas, ou a dança do Oriente com as suas províncias, ou ainda a dança militar de Ceifadino com seus pajens, bem como a dança dos Elementos da Natureza, no Ato II.

O Coro de tapuias e aimorés, que aparece por diversas vezes em cena, carregado de cor local, teria certamente muito mais impacto visual sobre o público do que os Coros convencionais do final do Ato II e III. E o mesmo se pode dizer da música celestial que acompanhou o descerrar da Glória, primeiro para trazer à terra o Anjo da Guarda do Oriente, depois para revelar a visão sobrenatural da Cruz de Cristo. Ela corresponde a um género musical puramente instrumental, sinal inequívoco da maturidade que a instrumentação já havia alcançado. E não é indiferente que o dramaturgo tenha associado essa novidade do género a um momento dramático deliberadamente epifânico.

Sobre a autoria da composição dos Coros, Sardinha Mimoso dá-nos uma informação bastante sumária, mas que não contradiz a prática tradicional dos Actos públicos dos Colégios, que consistia em chamar a colaborar com o Colégio, artistas locais do melhor nível: Los Choros de musica fueron de los mejores Maestros desta profession que ay en Lisboa... (Prefácio Al Curioso Lector). Diversos testemunhos da prática musical e dramática dos Colégios em Portugal, ao longo da segunda metade do século xvi, apontam efetivamente nesse sentido (Miranda 2006a). 
O mesmo se pode dizer dos respetivos intérpretes, que eram músicos chamados pelos padres, ou mesmo oferecidos pelos benfeitores dos Colégios, para solenizar os Atos. A alusão, no prefácio latino, à distribuição das partes entre atores e músicos sugere a especialização destes últimos, como aconteceu, por exemplo, com os cantores dos Coros da Tragédia de Acab, representada em Coimbra em 1562. O mesmo indício está presente na referência explícita de Sardinha Mimoso aos menestréis que executaram a música que despediu as personagens no fim do Prólogo (fol. 9). Músicos seriam também os responsáveis pela execução do caelestis concentus que acompanhava o descerrar da Glória para a visão do Anjo e a visão da Cruz, no meio da maior variedade de instrumentos.

A colaboração de músicos profissionais na composição e na execução do espetáculo não impedia porém os colegiais e o dramaturgo de recorrerem a processos de contrafactum, permitindo que a produção de certos textos musicais partisse de outro texto precedente, num fenómeno de intertextualidade não raro na poética literária, que podia estender-se à poética musical. No entanto, na Tragicomédia do Rei Dom Manuel, os contrafacta reduzem-se aos cantos dos tapuias, no entremez que sucede ao Acto III, e provavelmente, o canto dos mesmos no interior do Acto III, em que as saudações ao rei são feitas ao modo dos vilancicos. Trata-se, sem dúvida, de canções novas, criadas sobre o modelo formal - métrico e musical - de canções tradicionais anteriores, conhecidas pelos atores e pelo público (Pedrosa 2004; Enterria 1995).

Contínuo de quadros de grande impacto sensorial, a Tragicomédia do Rei Dom Manuel apresenta uma multiplicidade de Coros que entram e saem de cena sem outra intenção dramática que não seja a de impressionar vivamente todos os sentidos do público. A fantasia alegórica representada diante de Filipe III de Espanha revela uma complexidade cenográfica e coreográfica inacreditável. O efeito de certas cenas de maquinaria (com as inevitáveis elevações 'em voo', como as aparição do Anjo e da Cruz), ou a cena dos Infernos vomitando fumo e demónios, ou o assalto à muralha de Ormuz, bem como a navegação da nau da Índia por entre as ondas, indicia um grau de técnica espetacular extraordinariamente elevado (Granja 1982 e 1995). E se houve apenas vinte e cinco dias para preparar o espetáculo, é porque os principais instrumentos técnicos eram já conhecidos da cenografia jesuítica, isto é, o 
Colégio podia recorrer a técnicas teatrais já testadas, tributárias de toda uma tradição artística anterior.

Cenografia e coreografia reproduziam os cânones figurativos da pintura barroca e traziam ao palco a incarnação das pinturas fantásticas de Andrea Pozzo, com o mesmo grau de fantástico, com o mesmo poder sugestivo, com o mesmo impacto visual - alegorias suspensas entre nuvens, aparições, triunfos, apoteoses, Anjos, monstros e demónios. A finalidade didática do teatro passara para segundo plano, para dar lugar à expressão de grandeza e sumptuosidade. Por isso a música, de cujo texto nada mais conhecemos a não ser o texto verbal, não podia deixar de ser a expressão da mesma magnificência. Salvas de trombetas, charamelas, tambores e atabales para os momentos de festa e de apoteose - como na saudação inicial ao Rei, ou no Coro festivo do anúncio da sucessão de Afonso de Albuquerque a Dom Francisco de Almeida; instrumentos de corda e de sopro (harpa e baixão) para a música dos seres míticos do Oceano, os Tritões; plena variedade de instrumentos (variedade de cordas e variedade de sopros) para a música divina dos Anjos e da Glória celeste, como na visão do Anjo e na visão da Cruz; flautas, tambores, pandeiros, sistros (cestros) e guizos (sonajas) para a música popular de pastores - como as folias com que os músicos serranos celebram o regresso de Vasco da Gama, ou a música que acompanha as acrobacias dos dez foliões, no entremez do Ato III.

De resto, toda a composição dramática se inspira no convencionalismo das cerimónias das entradas régias: triunfos, paradas, salvas de tiros, cortejos, música e coros, danças e folias. É a cidade que se veste de festa para celebrar a visita do rei e que se representa a si própria em festa. Ao por em cena as próprias celebrações, a cerimónia mais não faz do que representar a sua própria representação - como acontece no entremez do Ato III e no triunfo final - num excesso de significantes e de significados tipicamente barroco.

O espetáculo jesuítico ganhara assim uma feição marcadamente visual, que atraía não só aqueles que tinham capacidade para compreender as longas récitas em latim, de grande intensidade retórica, mas também os populares que, no dia das representações, enchiam o pátio do colégio.

Para os dramaturgos jesuíticos do século xvi e XVII, tornara-se de facto evidente o princípio da linguagem teatral como multiplicidade de códigos e 
de signos linguísticos e extralinguísticos, inalienável da atual teoria literária e dramática. Assim, a riqueza cenográfica acabou por constituir uma das heranças mais específicas do teatro jesuítico para o teatro barroco europeu.

Uma linguagem cénica cada vez mais elaborada, a tendência crescente para a profusão de elementos decorativos, uma caracterização mais rica, em detrimento de uma caracterização mais simbólica, a experimentação de novas soluções para o tratamento do espaço, a participação crescente da música, os primeiros passos para a construção da ilusão cénica, enfim, o gosto pela sumptuosidade e a magnificência não resultam apenas da vinculação do teatro jesuítico à língua latina e da necessidade de deslumbrar o público, mas também de uma consciência teórica inovadora em relação à maneira de produzir teatro e de seduzir o público. Refiro-me a uma consciência teórica que reconhecia a relação natural existente entre teatro e retórica. Essa relação acabou por fazer com que o canto fosse a suprema actio da voz, e a dança, a suprema actio do corpo. Assim vista, essa consciência teórica não pode ser alheia aos fundamentos da mais característica cenografia barroca.

\section{Bibliografia}

Alenda, Jenaro (1903) Relaciones de solemnidades y fiestas de España, 1903.

Alvarenga, João Pedro de (1994), Fábrica de Sons. Instrumentos de Música Europeus dos séculos XVI a XX. Lisboa, Capital Europeia da Cultura.

Alves, Ana Maria (1988) As Entradas Régias Portuguesas, Lisboa, Livros Horizonte.

Benatti, Marica (2008), Simulacri Imperiali Porthoghese: La „Entrada Real“ di Lisbona del 1619 e la Monarchia Duale. Dottorato di Ricerca in Iberistica, Università degli Studi di Bologna.

Briesemeister, Dietrich (2006), "O Teatro escolar jesuítico e os Descobrimentos Portugueses: António de Sousa e La Real Tragicomedia del Rey Dom Manoel" in Sebastião Tavares de Pinho (Coord.) Teatro Neolatino em Portugal no Contexto da Europa. Coimbra: 127-142.

Chiabó, M.; Doglio, F., ed. (1994), Atti del XVIII Convegno Internazionale I Gesuiti e $i$ Primordi del Teatro Barocco in Italia, Roma, Edizione Torre d'Orfeo.

Cruz, Luís da (1989), O Pródigo. Tragicomédia Novilatina. Prefácio, treslado e notas por J. Mendes de Castro. Introdução e tradução do Prólogo por R. M. Rosado Fernandes, Lisboa.

Ferrer Valls, Teresa (1993), Nobleza y espectáculo teatral, 1535-1622: estúdio y documentos. Universitat de Valencia.

García de Enterría, María Cruz (1995), "Bailes, romances, villancicos: modos de reutilización de composiciones poético musicales”, in María Antonio Vigili Blanquet 
et ali (eds.), Música y literatura en la Península Ibérica: 1650-1750. Valladolid: 169-184.

Granja, Agustín de la (1982), Del teatro en la España barroca: Discurso y escenografia. Granada, Universidad.

Granja, Agustín de la (1995), "El actor en las alturas: de la nube angelical a la nube de Juan Rana”, Cuadernos de Teatro Clásico 8 37-67

Mamczarz, Irene (1994), "La Trattatistica dei Gesuiti e la pratica teatrale al Collegio Romano: Maciej Sarbiewski, Jean Dubreuil e Andrea Pozzo" in M. Chiabó; F. Doglio ed. (1994): 349-388;

Martins, Mário (1986), o Teatro nas Cristandades Quinhentistas da índia e do Japão. Lisboa.

Mcgowan, Margaret M. (1963), L'Art du Ballet de Cour em France 1581-1643, Paris, Centre National de la Recherche Scientifique, maxime 205-227.

Mimoso, Sardinha (1620), Relación de la Real Tragicomédia com que los Padres de la Compañia de Jesus en su Colégio de S. Anton de Lisboa recebieron a la Magestad Católica de Filipe II de Portugal... Impresso en Lisboa por Jorge Rodriguez.

Miranda, Margarida (2003) «Música para o teatro humanístico em Portugal: Dom Francisco de Santa Maria, Miguel Venegas S. I. e o Colégio das Artes de Coimbra (1559-1562)", Humanitas 55 315-340.

Miranda, Margarida (2006a) «Teatralidade e linguagem cénica no teatro jesuítico em Portugal (séc. xvi)» Humanitas 58 391-409.

Miranda, Margarida (2006b), Teatro nos Colégios dos Jesuitas. A Tragédia de Acab de Miguel Venegas S. I. e o início de um género dramático (séc. XVI). Lisboa, Fundação Calouste Gulbenkian.

Miranda, Margarida (2010), "O teatro, o palco e o púlpito na Ratio Studiorum (1599)" in Pereira, Belmiro e Várzeas, Marta (2010) Retórica e Teatro. A palavra em acção. Universidade do Porto: 249-262.

Miranda, Pedro (2005), "Música dramática de D. Francisco de Santa Maria: contexto e génese" in Nascimento, Aires e Barbosa, Manuel de Sousa (Eds.), Luís da Cruz S. J. e o teatro jesuítico nos seus primórdios (1604-2004). Lisboa, Centro de Estudos Clássicos: 123-145.

Morelli, G. e Sala, E. (1994), "Teatro gesuitico e melodramma: incontri, complicità, convergenze," M. Zanardi (ed.) I gesuiti a Venezia, Pádua, 597-611;

Pedrosa, José Manuel (2004), "Las canciones contrahechas: hacia una poética de la intertextualidade oral" in Pedro M. Piñero Ramirez et ali (ed.), De la Canción de amor medieval a las soleares. Actas del III Congresso Internacional Lyra Minima Oral, Sevilla, Universidad: 449-469.

Pereira, Belmiro Fernandes e Várzeas, Marta (org.) (2010), Retórica e Teatro. A palavra em acção. Universidade do Porto.

Pires, Cecília (2010), A Real Tragicomédia do Rei Dom Manuel, de António de Sousa, um modelo de literatura independentista. Tese policopiada, apresentada à Faculdade de Letras da Universidade de Coimbra.

Soares, Nair de Nazaré Castro (32010), Diogo de Teive. Tragédia do Príncipe João. Coimbra, Centro de Estudos Clássicos e Humanísticos.

Strappini, Lucia e Trenti, Luigi (1998), Bernardino Stefonio, Crispus Tragoedia, Roma, Bulzoni Editore, 1998. 
José Maria Pedrosa Cardoso

Centro de Estudos Clássicos e Humanísticos - Universidade de Coimbra

\section{EM BUSCA DO PECULIAR NA MÚSICA SACRA PORTUGUESA DOS SÉCulOS XVI, XVII E XVIII}

"Não há dúvida de que a polifonia vocal e sacra portuguesa constitui um corpus peculiar, distinto dos seus congéneres espanhol e italiano, não obstante todos os três não poderem encobrir a sua vetusta ascendência neerlandesa" (Kastner 1982: XXV).

\section{Introdução}

Desde o início do século xvi, e até finais do xviII, Portugal passou sucessivamente por alguns dos momentos mais altos e mais baixos da sua história. A gesta dos Descobrimentos chegou ao seu apogeu em torno de 1500 e a grandeza do Império afirmou-se vistosamente no tempo de D. Manuel mas, já durante o reinado de D. João III, surgiram os primeiros sinais de uma decadência generalizada que afundaria o país económica e politicamente sob uma longa crise de identidade (Saraiva 1983: 475-490; Serrão 1985: 270-274; Mendes 1993: 413). A subida ao trono de D. João V, coincidente com o crescimento da economia devido às riquezas provenientes do Brasil, foi a conjuntura que tentou levantar de novo o nome de Portugal na Europa das Luzes.

Durante estes três séculos, as artes envolveram a vida dos Portugueses em proporção desigual. O início do século xvi ficou marcado com grandes obras, a representarem a grandeza de um Império, v. c. a renovação urbana de Lisboa, a construção do Terreiro do Paço e do Mosteiro dos Jerónimos bem como a reconstrução de Santa Cruz de Coimbra juntamente com os 
túmulos reais. Do mesmo modo, no retomar do nó da onda, D. João V afirmou o seu poder no Convento de Mafra, no aqueduto das Águas Livres, na Igreja dos Clérigos do Porto e na Biblioteca Joanina de Coimbra, enquanto D. José I ficará na História não só na célebre estátua da Praça do Comércio mas também no apoio dado ao Marquês do Pombal, imortalizado na reconstrução da baixa de Lisboa.

Entre estes dois extremos, e para além de uma arte plástica condicionada pela religião, a música sacra impõe-se claramente sobre qualquer outra espécie musical: no tempo da crise nacional, em dependência do espírito da Contra-Reforma; na época das luzes, como representação de um poder entronizado pela Fé.

O peso da música sacra, aumentou efetivamente com o incremento das escolas junto das catedrais, de alguns mosteiros e mesmo da Capela Real e da Capela Ducal de Vila Viçosa. Coimbra (Pinho 1981), Évora (Alegria 1973, 1997 e 2004), Vila Viçosa (Alegria 1983), Braga (Lessa 1992 e Alvarenga 1988) e Lisboa (Borges 1986), os principais centros de estudo de música prática nos séculos XVI e XVII, acabaram por constituir as grandes escolas onde moços de coro, ou jovens sem mais, aprenderam a arte contrapontística que marcou a produção nacional, sempre no âmbito da Igreja. A Capela Real foi assinalável centro de produção, pelo menos desde o século xv, mas é no século xviII que se assiste, em Portugal, ao aparecimento do Seminário da Patriarcal, a grande escola que formará simultaneamente os cantores da Igreja Patriarcal (a Capela Real) e os primeiros compositores de música dramática em Portugal (Fernandes 2009), um caso paradigmático da afirmação do poder da música sacra sobre a profana e, ao mesmo tempo, da influência da Capela Real sobre as restantes Igrejas diocesanas ou monacais.

\section{A realidade da música sacra em Portugal}

Sabe-se que muita música sacra produzida na época em estudo ficou perdida nas brumas do tempo. Todavia, embora mal conservada, mal tratada, pouco conhecida e ainda menos estudada (lembremos apenas a falta de catálogos adequados), aquela que chegou ao nosso conhecimento é bastante para 
impor a admiração e apreço de quantos se interessam pela cultura imaterial portuguesa. Será demasiada ousadia tentar vislumbrar na prática desta grande música alguns rasgos de originalidade que eventualmente a caracterizem?

\subsection{O cantochão em Portugal}

Os grandes livros de coro e de cantochão frequentemente (mal) expostos em arquivos e museus de Portugal são objecto de admiração pelo seu vulto e pela beleza da sua escrita, frequentemente decorada com preciosas iluminuras. Muitos outros, em estado mais deteriorado, ou sem grande apetência visual, aguardam a investigação dos peritos. Todos eles contêm informação valiosa sobre reportórios, rubricas, modelos musicais que muito podem ajudar a compreender o alcance da prática de tal música nas igrejas e mosteiros portugueses, como é o caso dos tão pesados como preciosos Livros de Coro de Santa Cruz de Coimbra, hoje depositados na Biblioteca Geral de Universidade de Coimbra (MM 118 a MM 144), todos eles executados em meados do séc. XviII. Todavia, em paralelo com grandes ou pequenos livros manuscritos, existem também livros impressos de cantochão de grande ou de pequeno formato. Muitos importados, mas muitos outros impressos já em Portugal.

A aplicação dos caracteres móveis aos símbolos da escrita musical, iniciada em Itália e França nas primeiras décadas de Quinhentos, entrou rapidamente em Portugal. Foi D. João III quem incentivou as artes da impressão musical, pois em 1533 e 1535 saíram as primeiras obras de música impressa: os tratados de Cantochão e de Contraponto de Mateus de Aranda, um músico contratado para Évora pelo seu irmão o Cardeal D. Afonso, e que ele mesmo chamaria para a Universidade de Coimbra em 1544. Mas é o seu capelão cantor Diogo Fernandes Formoso quem publicará a que é provavelmente a primeira obra de música litúrgica em Portugal, o Passionarium secundum ritum capelle regis Lusitanie (Lisboa, 1543), um livro justificado certamente pela sua utilidade - à música das quatro Paixões junta não só o reportório litúrgico da Semana Santa, com as peças processionais do Domingo de Ramos, as Lições do Ofício das Trevas e o Exultet, mas também as primeiras estrofes dos hinos do ofício diurno e noturno de todo o ano 
- e que simultaneamente documenta a relação desta música com a prática da Capela Real.

Antes ainda de outros reportórios imprimiram-se mais dois Passionários: o de Manuel Cardoso, cantor da Capela Real e Tesoureiro da Diocese de Leiria (Leiria, 1575) e o de Fr. Estêvão, da Ordem de Cristo (Lisboa, 1595). Já no século seguinte, um novo espécime com a música litúrgica da Paixão, na linha dos anteriores e contendo igualmente um modelo monofónico de cunho tipicamente português (Cardoso 2004 e 2006): o Liber Passionum de Fr. Manuel Pousão (Lyon, 1675). A edição destes quatro passionários impressos, juntamente com os passionários manuscritos da mesma época, indiciam já por si o interesse dos portugueses pelo reportório da Semana Santa.

A prática do canto gregoriano, beneficiando também da invenção de Guttenberg, teve também em Duarte Lobo e Filipe de Magalhães dois músicos de prestígio: aquele publicou em Lisboa (1603) um Ordo amplissimus precationum caeremoniarumque funebrium..., um manual de música para a liturgia de defuntos, e também, pouco depois, um Liber processionum et stationum ecclesiae Olysiponensis (Lisboa, 1607), com outra edição, pelo menos, em 1728; Filipe de Magalhães, igualmente colaborante do sodalício dos sacerdotes pobres publicou o seu Cantum ecclesiasticum (Lisboa, 1614), um manual igualmente fúnebre que teria edições sucessivas durante mais de cem anos.

São numerosas as Artes de Cantochão publicadas em Portugal, desde a traduzida de João Martins (Juan Martínez, de c. 1560) e a de Pedro Thalesio (Coimbra, 1618).

Além do Enchiridium missarum solemnium et votivarum cum vesperis et completis totius anni, necnon officio defunctorum et aliis juxta morem S.R.E. et reformationem missalis ac Breviarii ex decreto Concilii Tridentini... [pelo Pe. João Dias, chantre da Sé de Coimbra], Coimbra, 1580, uma obra eclética de utilidade reconhecida para a prática da música litúrgica e que viria a ser reeditada um século mais tarde, agora sob a orientação de Matias de Sousa Vilalobos, mestre de capela da Sé de Coimbra, nesta cidade em 1691, e passando por rituais e manuais configurados por objectivos geralmente monacais, é preciso referir um livro fundamental: o Theatro Ecclesiastico de Fr. Domingos do Rosário, que saiu em Lisboa em 1743 e que obteve 
sucessivas edições paulatinamente modificadas até à sua nona impressão em 1817. A importância deste livro reside, antes de mais, no facto de ser um primeiro grande testemunho da mudança operada em Portugal, também neste capítulo da música sacra, durante o reinado do Rei Magnânimo, após a chegada dos mestres italianos, nomeadamente o compositor e cantochanista Giovanni Giorgi (?-1762).

\subsection{A Polifonia}

A produção de polifonia sacra em Portugal durante os séculos XVI e XVII atingiu um nível elevado e o legado dos nossos compositores constitui um verdadeiro tesouro vertido em obras impressas na época e em numerosos manuscritos felizmente resgatados das inclemências do passado.

A polifonia portuguesa impressa de autor declarado data do século xviı, na sua quase totalidade, como se pode ver no quadro seguinte:

\begin{tabular}{|c|c|c|c|}
\hline Edição & Compositor & Título & Conteúdo \\
\hline 1602, Antuérpia & Duarte Lobo & $\begin{array}{l}\text { Opuscula } \\
\text { natalitiae noctis }\end{array}$ & $\begin{array}{l}8 \text { resp. de Natal a } 4 \text { e os mesmos } \\
\text { a } 8 \text { vv; missa de Natal a } 8 \text {; as } \\
\text { antífonas de N. Senhora a } 8 \text { e } \\
11 \text { vv. }\end{array}$ \\
\hline 1605, Antuérpia & Duarte Lobo & $\begin{array}{l}\text { Cantica Beatae } \\
\text { Mariae Virginis, } \\
\text { vulgo Magnificat }\end{array}$ & $\begin{array}{l}\text { Versos pares e impares, ambos } \\
\text { nos } 8 \text { tons: } 16 \text { peças num total de } \\
96 \text { versículos }\end{array}$ \\
\hline 1621, Antuérpia & Duarte Lobo & $\begin{array}{l}\text { Liber Missarum } \\
I V, V, V I, V I I I v v\end{array}$ & $\begin{array}{l}\text { Antífonas da aspersão; } 8 \text { missas; } \\
2 \text { motetos. }\end{array}$ \\
\hline 1639, Antuérpia & Duarte Lobo & $\begin{array}{l}\text { Liber II Missarum } \\
\text { IIII, Vet VI vv. }\end{array}$ & $\begin{array}{l}\text { Antífonas da aspersão; } 7 \text { missas; } \\
1 \text { responsório. }\end{array}$ \\
\hline 1609, Lisboa & Francisco Garro & $\begin{array}{l}\text { Missae quatuor, } \\
\text { defunctorum } \\
\text { lectiones... }\end{array}$ & $\begin{array}{l}4 \text { missas a } 8 \text { e } 12 \text { vv, bc; } 3 \\
\text { aleluias de Missas a } 8 ; 3 \text { lições de } \\
\text { defuntos a } 8 .\end{array}$ \\
\hline 1609, Lisboa & Francisco Garro & Opera aliquot & $\begin{array}{l}\text { Antífonas da aspersão a } 5 \text { e } 6 \text { vv; } \\
4 \text { missas a } 4,5 \text { e } 6 \text { vv; } 3 \text { motetos } \\
\text { a } 5 \text { e } 6 \text { vv. }\end{array}$ \\
\hline 1613, Lisboa & $\begin{array}{l}\text { Fr. Manuel } \\
\text { Cardoso }\end{array}$ & $\begin{array}{l}\text { Cantica Beatae } \\
\text { Mariae Virginis }\end{array}$ & $\begin{array}{l}16 \text { peças ( } 8 \text { a } 4 \mathrm{vv}, 8 \text { a } 5 \mathrm{vv}) \text {, com } \\
\text { os versículos do Magnificat para } \\
\text { se cantarem alternatim. }\end{array}$ \\
\hline
\end{tabular}




\begin{tabular}{|c|c|c|c|}
\hline 1625, Lisboa & $\begin{array}{l}\text { Fr. Manuel } \\
\text { Cardoso }\end{array}$ & $\begin{array}{l}\text { Liber primus } \\
\text { missarum }\end{array}$ & $\begin{array}{l}\text { Antífonas da aspersão } 4 \text { vv; } 7 \\
\text { missas a } 4,6 \text { e } 8 \text { vv; } 1 \text { missa pro } \\
\text { defunctis a } 8 \text { vv; } 2 \text { motetos a } 5 \\
\text { e } 6 \mathrm{vv} \text {. }\end{array}$ \\
\hline 1636, Lisboa & $\begin{array}{l}\text { Fr. Manuel } \\
\text { Cardoso }\end{array}$ & $\begin{array}{l}\text { Liber secundus } \\
\text { missarum }\end{array}$ & $\begin{array}{l}\text { Antífonas de aspersão a } 4 \mathrm{vv} ; 7 \\
\text { missas a } 6,5 \text { e } 4 \mathrm{vv} \text {. }\end{array}$ \\
\hline 1636, Lisboa & $\begin{array}{l}\text { Fr. Manuel } \\
\text { Cardoso }\end{array}$ & $\begin{array}{l}\text { Liber tertius } \\
\text { missarum }\end{array}$ & $\begin{array}{l}6 \text { missas } A b \text { initio et ante saecula } \\
\text { a } 4,5 \text { e } 6 \mathrm{vv} ; 2 \text { missas a } 4 \mathrm{vv} \\
\text { (uma das quais, a "Filipina"). }\end{array}$ \\
\hline 1648, Lisboa & $\begin{array}{l}\text { Fr. Manuel } \\
\text { Cardoso }\end{array}$ & $\begin{array}{l}\text { Livro de vários } \\
\text { motetes, Ofício de } \\
\text { Semana Santa e } \\
\text { outras coisas... }\end{array}$ & $\begin{array}{l}\text { Asperges a } 4 \text { vv; } 2 \text { missas: } \\
\text { para Advento e Quaresma e } \\
\text { Pro defunctis; } 22 \text { motetos a } \\
4,5 \text { e } 6 \mathrm{vv} ; 3 \text { hinos a } 4 \mathrm{vv} ; 8 \\
\text { responsórios, } 4 \text { lamentações a } \\
6 \text { e } 4 \text { vv e } 5 \text { lições de trevas e } \\
\text { defuntos a } 4 \mathrm{vv} \text {; Miserere a } 4 \mathrm{vv} \text {. }\end{array}$ \\
\hline 1636, Lisboa & $\begin{array}{l}\text { Filipe de } \\
\text { Magalhães }\end{array}$ & Missarum liber & $\begin{array}{l}8 \text { missas a } 4,5 \text { e } 6 \text { vv; um moteto } \\
\text { a } 6 \text { vv. }\end{array}$ \\
\hline 1636, Lisboa & $\begin{array}{l}\text { Filipe de } \\
\text { Magalhães }\end{array}$ & $\begin{array}{l}\text { Cantica } \\
\text { Beatissimae } \\
\text { Virginis }\end{array}$ & $\begin{array}{l}16 \text { peças com os versículos pares } \\
\text { e ímpares do Magnificat. }\end{array}$ \\
\hline 1657, Roma & $\begin{array}{l}\text { J. Lourenço } \\
\text { Rebelo }\end{array}$ & $\begin{array}{l}\text { Psalmi tum } \\
\text { vesperarum tum } \\
\text { completorii... }\end{array}$ & $\begin{array}{l}2 \text { versões de } 7 \text { salmos de } \\
\text { Vésperas, } 4 \text { Magnificat, todas } \\
\text { as peças de Completas, } 2 \\
\text { lamentações e o salmo Miserere, } \\
\text { a } 4,6,8,12 \text { e } 16 \mathrm{vv} \text {, com instr. } \\
\text { e b.c. }\end{array}$ \\
\hline 1792, Lisboa & $\begin{array}{l}\text { José Joaquim dos } \\
\text { Santos }\end{array}$ & Stabat Mater & $\begin{array}{l}\text { Sequência a } 3 \text { vv, } 2 \text { sopranos e } \\
\text { baixo, } 2 \text { violetas e vcl. }\end{array}$ \\
\hline
\end{tabular}

Uma leitura atenta deste quadro permite descobrir aspectos que vale a pena salientar.

Antes de mais, ficam aqui representados alguns dos principais compositores da chamada época de ouro da polifonia portuguesa: depois de Francisco Garro (c.1556-a.1623), um espanhol ao serviço dos Duques de Bragança e da Capela Real, aparecem os nomes de Duarte Lobo (c. 1565-1646), Fr. Manuel Cardoso (1566-1650), Filipe de Magalhães (c.1565-1652) e João Lourenço Rebelo (1610-1661), das escolas de Évora e Vila Viçosa.

Chama a atenção a grande distância no tempo entre a última obra impressa de autor conhecido, em 1657, e a primeira do século seguinte, em 1792. A que se deve isto, uma vez que havia tanta música e tanto dinheiro 
no tempo de D. João $\mathrm{V}$ e seus sucessores? A dificuldade invocada para a crise pós-restauracionista pode explicar alguma recessão económica que terá eventualmente impedido a impressão de música, o que explica que o Liber Passionum de Fr. Manuel Pousão, um espécime muito próximo dos passionários quinhentistas já citados, fosse impresso em Lyon em 1675. A conjuntura sociopolítica não era favorável e a oficina craesbeckiana pode ter perdido a capacidade técnica de impressão musical.

De facto ainda nos últimos anos do século XVII e em todo o século XviII foram impressos em Portugal diversos livros de música sacra mas, à exceção de umas Preces que se devem cantar nos dias da novena... S. Joseph a $4 \mathrm{vv}$ (Lisboa, 1724), de autor anónimo (Albuquerque 2006: 34), eram todos de cantochão prático ou teórico, salientando-se as obras de Nunes da Silva, João Vaz Barradas Muito Pão e Morato, Pe. Luís da Maia Croesser's, Fr. Domingos do Rosário, Fr. Manuel da Conceição e Fr. Veríssimo dos Mártires (Andrade 1992: 163-173). Em toda esta época imprimem-se libretos de vilancicos e até de ópera, mas música concertante sacra não consta ter aparecido até ao Stabat Mater de José Joaquim dos Santos (1747-1801), em 1792.

Esta omissão pode remeter para a austeridade aplicada aos recursos eclesiásticos na prática de uma música de aparato, ou então para a formação de um gosto social em favor dos vilancicos barrocos. Efetivamente sabe-se que estes se cantavam em grande abundância. Verifica-se aqui um fenómeno já conhecido: o vilancico como expressão musical efémera, que devia mudar de ano para ano. Se a música podia desaparecer - não fazia falta a sua impressão nem sequer a cópia, porque não seriam repetidos - o texto era sempre necessário para uma melhor compreensão dos mesmos, o que também supõe alguma complexidade na sua forma e expressão (Lopes 2007).

Vale também a pena salientar as obras preferidas para a impressão. Verifica--se o predomínio das Missas - sete livros específicos: dois de Duarte Lobo, três de Fr. Manuel Cardoso, um de Filipe de Magalhães e um Francisco Garro, além de missas dispersas por outros livros (57 missas no total) - mas chama a atenção a impressão de três livros de Magnificat (Duarte Lobo, Fr. Manuel Cardoso e Filipe de Magalhães). No seu todo, juntamente com os espécimes de João Lourenço Rebelo, um total de 52 versões do cântico de Nossa Senhora sai impresso em Portugal num espaço de 31 anos. Este dado, mesmo tendo em 
conta a produção romana, sobretudo de P. E. Palestrina (1525-1594), evidencia a grande procura dessa composição litúrgica, numa época contrarreformista na qual em Portugal, ao tempo politicamente unificado com Espanha, tanto se promoveu o culto da Nossa Senhora da Conceição graças ao empenhamento das Ordens Religiosas, das Universidades e dos próprios monarcas (Marques 2000: 629).

Deve também salientar-se a abundância de motetos impressos (27) e ainda de responsórios de Natal e Semana Santa (17). Na sua totalidade, estes livros de música impressa em Portugal na primeira metade do século xvir salientam a importância do reportório da Missa (Ordinário), mas porventura ainda mais o interesse nas rubricas do Ofício Litúrgico: salmos, Magnificat, hinos e lições.

A título de curiosidade, considerando a dedicatória de todos estes livros, refira-se que, na realidade, o Duque de Bragança e futuro Rei D. João IV, teve que ser muito bom mecenas, pois foi dedicatário de 6 livros de polifonia entre os 8 publicados desde 1625 a 1657. José Augusto Alegria não divagou de todo ao descobrir nos títulos das missas de Duarte Lobo, Fr. Manuel Cardoso e Filipe de Magalhães alguma intenção panfletária a favor de uma restauração desejada (Alegria 1983: 48-49). Já no que respeita a música manuscrita não é possível obter dados objetivos sobre a quantidade e qualidade da música sacra arquivada ainda em Portugal. Efetivamente dos numerosos fundos musicais existentes, apenas têm catálogo os da Biblioteca da Ajuda, da Biblioteca Pública Municipal do Porto, da Biblioteca do Palácio Nacional de Mafra, da Biblioteca Publica de Évora, da Sé de Évora, da Biblioteca do Palácio de Vila Viçosa. Catálogos feitos mas não publicados são os da Sé Patriarcal e do Seminário de São José de Faro. Nos restantes arquivos existem apenas simples inventários, por vezes parcelares, como é o caso da Biblioteca Geral da Universidade de Coimbra (BGUC), ou coisa nenhuma, o que dificulta obviamente ter ideias precisas sobre espécimes provenientes das instituições em referência. Alguns deles apresentam documentação musical muito diversificada no tempo, como é o caso do catálogo da Ajuda. Mesmo assim, do conhecimento precário dos arquivos de música histórica em Portugal, há uma conclusão evidente: o predomínio quase total de música sacra embora, em grande parte, em composições de autor anónimo. 
Refiram-se, a título de exemplo, as informações possíveis sobre o fundo de Santa Cruz da Biblioteca Geral da Universidade de Coimbra e sobre os 20 livros de Vila Viçosa.

Segundo um inventário provisório, dactilografado e incompleto, por abranger apenas 200 manuscritos musicais (Cortez 1992), entre os manuscritos daquela Biblioteca, e apenas no que se refere ao fundo de Santa Cruz, encontramos:

- 32 livros de cantochão, homogéneos e de grandes dimensões, porventura a maior e mais completa colecção de livros de coro existente em Portugal pertencente a uma única instituição;

- 25 livros de polifonia, entre os quais figura a grande música sacra dos compositores crúzios;

- e 11 volumes de música instrumental, quatro dos quais com música de Carlos Seixas.

Do conjunto de apenas estes livros - sabe-se por umas fichas existentes na área de reservados da BGUC que existem outros cartapácios com música polifónica de Santa Cruz, nomeadamente os MM 217, 230, 231 e 242 - e no respeitante à música polifónica produzida ou praticada em Santa Cruz, aparecem cerca de 35 compositores, dos quais 15 portugueses, entre os quais os Cónegos Regrantes D. Francisco de Santa Maria, D. Pedro de Cristo, D. Heliodoro de Paiva, D. Bento, D. Pedro da Esperança e D. Gaspar da Cruz, e ainda Vasco Pires, Fernão Gomes Correia, António Carreira, Pêro do Porto (Escobar), Aires Fernandes, etc. Entre os estrangeiros, registem-se os nomes de Mouton, Willaert, De la Rue, Baldwein, Morales, Guerrero, Richafort, Verdelot, Bruxell, Anchieta, Peñalosa, etc. Em contraste com os 35 nomes conhecidos, alguns dos quais representados em várias composições, existem 5 livros inteiramente preenchidos por peças de compositores anónimos, o que, em conjunto com muitas outras constantes de livros com autores atribuídos, faz um total de mais de 600 peças de compositor anónimo, elevando para muito acima do milhar as obras de polifonia existente na BGUC.

Interessa também verificar o conteúdo destes códices polifónicos de Santa Cruz de Coimbra: como em quase todos os livros deste tipo predominam as 
missas, os salmos, os responsórios e os motetos. Chama também a atenção a abundância de versos polifónicos do Magnificat: há mais de 52 composições de Magnificat em 13 códices, recolhendo-se, por vezes verdadeiras séries tais como a série de 7 de Luis Morán (MM 32), a série de 8 de autor anónimo (MM 8 e MM 12), o que identifica o interesse em coleccionar composições da mesma rubrica para os vários tons, tal como acontecerá aos Impressos do séc. XVII. A abundância destas composições só pode identificar uma prática litúrgica muito dependente desta forma musical.

De uma análise um pouco mais atenta a estes manuscritos de Santa Cruz torna-se já evidente a abundância de música polifónica da Paixão (presente em várias formas e em diversos manuscritos: os MM 18, 26, 32, 47, 53 e, sobretudo, o MM 56) e também, de uma forma mais alargada, em música da Quaresma e Semana Santa: vários códices só com esse reportório (MM 25 e 26) outros com a maioria (MM 47) e outros ainda com peças misturadas.

Mas a nossa atenção pode também centrar-se nos 20 livros de Polifonia de Vila Viçosa, catalogados por Manuel Joaquim (Joaquim 1953).

Estes não são os livros do Paço Ducal de Vila Viçosa - catalogados por José Augusto Alegria (Alegria 1989) - e representam apenas uma amostra do fundo musical ainda existente naquele palácio. Uma boa parte, se não a totalidade, daqueles livros foram levados para Vila Viçosa depois de ter saído de lá a célebre Biblioteca Musical dos Duques de Bragança, levada para Lisboa para se tornar na Biblioteca Real de Música. Sabe-se que vários foram copiados na terceira década do século xviII, a mandato de D. João V, e para servirem naquela Capela Real.

\section{Correntes estilísticas}

Os primeiros compositores portugueses com obra conhecida - a saber: Pêro do Porto (c.1465-p.1635), Vasco Pires (fl. 1481/1509) e Fernão Gomes Correia (fl. 1505/1532) - foram ativos no tempo de maior prosperidade e de maior abertura de Portugal ao mundo e manifestam, naturalmente, uma relação natural com as correntes musicais provenientes da Itália e dos Países Baixos. Não seria possível, de acordo com os limites deste trabalho, valorar 
todos os compositores que deixaram composições para a história. Optando por tratar aqui os mais significativos no âmbito da música vocal sacra, vejamos na medida do possível o percurso estilístico dos mesmos: que traços genéricos definem os compositores em causa, que influências acusam, como se distingue a sua música face à dos restantes compositores coevos?

Com óbvia flexibilidade, é possível distinguir três épocas correspondentes a outras tantas correntes de estilo nas quais se podem enquadrar os mais importantes criadores de música sacra em Portugal, segundo os seguintes critérios: domínio do stile antico com a vigência do cantus firmus, c. 1500 a c. 1600; introdução do stile moderno, c. 1600 a c. 1700; introdução do concertante, c. 1700:

\begin{tabular}{|c|c|c|c|c|c|}
\hline \multirow[b]{2}{*}{ Círculo } & \multicolumn{2}{|c|}{ Stile Antico } & \multirow{2}{*}{$\begin{array}{c}\begin{array}{c}\text { Stile Antico } \\
+ \text { Moderno }\end{array} \\
1600\end{array}$} & \multicolumn{2}{|c|}{$\begin{array}{c}\text { Stile concertato alla } \\
\text { romana e concertante }\end{array}$} \\
\hline & 1500 & 1550 & & 1700 & 1750 \\
\hline Coimbra & $\begin{array}{l}\text { Vasco Pires } \\
\text { F. G. Correia } \\
\text { Hel. de Paiva }\end{array}$ & $\begin{array}{l}\text { Francisco de Sta } \\
\text { Maria, } \\
\text { Pedro Cristo }\end{array}$ & $\begin{array}{l}\text { Pedro da } \\
\text { Esperança } \\
\text { Gabriel de } \\
\text { S. João }\end{array}$ & & \\
\hline Évora & $\begin{array}{l}\text { P. do Porto } \\
\text { M. Aranda }\end{array}$ & M. Mendes & $\begin{array}{l}\text { A. Pinheiro } \\
\text { F. Martins } \\
\text { D. D. Melgás } \\
\text { Pedro Vaz Rego }\end{array}$ & $\begin{array}{l}\text { Francisco José } \\
\text { Perdigão }\end{array}$ & \\
\hline Lisboa & $\begin{array}{l}\text { P. do Porto } \\
\text { D. de Góis }\end{array}$ & A. Carreira & $\begin{array}{l}\text { F. Garro } \\
\text { F. Magalhães D. } \\
\text { Lobo } \\
\text { M. Cardoso } \\
\text { M. Lésbio }\end{array}$ & $\begin{array}{l}\text { H. C. Correia } \\
\text { D. Scarlatti } \\
\text { C. Seixas } \\
\text { J. R. Esteves } \\
\text { F. A. Almeida } \\
\text { A. Teixeira }\end{array}$ & $\begin{array}{l}\text { David Perez } \\
\text { J. S. } \\
\text { Carvalho } \\
\text { Brás de Lima } \\
\text { Leal Moreira } \\
\text { J. J. Santos } \\
\text { M. Portugal } \\
\text { J. J. Baldi }\end{array}$ \\
\hline $\begin{array}{l}\text { Vila } \\
\text { Viçosa }\end{array}$ & & A. Pinheiro & $\begin{array}{l}\text { R. Tornar } \\
\text { J. L. Rebelo } \\
\text { D. João IV } \\
\text { F. Almeida }\end{array}$ & & \\
\hline Braga & M. Fonseca & $\begin{array}{l}\text { P. Gamboa } \\
\text { L. Ribeiro }\end{array}$ & Pedro de Araújo & $\begin{array}{l}\text { António Baião } \\
\text { Magro }\end{array}$ & $\begin{array}{l}\text { António } \\
\text { Galasi }\end{array}$ \\
\hline Viseu & & E. L. Morago & & & \\
\hline
\end{tabular}

$\mathrm{Na}$ primeira época, os compositores sacros de Portugal, em fase de formação e organização a nível de escola, simultaneamente condicionados por ambientes pouco abertos, optam pelo stile antico com uma escrita a capella e com a adopção generalizada do cantus firmus (CF) como princípio gerador 
de polifonia sacra. Este CF é formado de melodias gregorianas, regra geral, pela razão óbvia de uma dependência natural da técnica do alternatim, seja na salmodia do Ofício, seja na própria missa. A arte polifónica aplicada aos salmos e cânticos evangélicos dificilmente se libertou da fórmula salmódica do gregoriano própria de cada modo.

A sua utilização manifestou-se, para além da antifonia, em que a capela alternava versículos em contraponto com versículos entoados sob a fórmula gregoriana pelo coro dos clérigos ou dos monges, na utilização do CF sob a técnica do fabordão, segundo a tradição italiana ou simplesmente hispânica, e na adoção da fórmula salmódica: como linha permanente em uma das vozes, como linha repartida por várias vozes ou simplesmente como motivo gerador de contraponto entre as diversas vozes. Está neste caso o admirável Magnificat de Pêro do Porto.

No caso da Missa, o CF pode estar presente ainda com as técnicas alternatim supondo, no caso do Ordinário, a alternância das invocações no Kyrie e Agnus Dei, ou dos versos, no Glória ou Credo. Outra maneira, ainda na Missa, é a possibilidade da utilização de um CF total em valores regulares, sobre o qual o compositor executa o seu contraponto ornamentado. Naquele caso está a Missa Orbis factor de Fernão Gomes Correia; neste, a coleção ainda pouco estudada do Liber introitus, do bracarense Miguel da Fonseca, dentro de uma prática bastante rara no contexto europeu (Alvarenga 2002: 35ss).

Para além desta dependência sistemática do CF, geralmente gregoriano, existe já a escrita polifónica sem qualquer motivo pré-existente, muitas vezes segundo processos compositivos muito cerebrais, em estreita proximidade da técnica canónica normal, ou estrita, dos compositores flamengos, como é o caso dos motetos de Damião de Góis.

Não se nega que esta dependência do CF não se prolongue pelo tempo, segundo a visão mais ou menos conservadora do compositor, o que acontecerá, aliás, ao longo dos tempos e com todos os estilos.

O Stile moderno terá entrado em Portugal de forma cautelosa através da adopção do baixo contínuo (BC) e da monodia acompanhada. Aquele apareceu em Portugal, em forma impressa pela primeira vez, e em proporção reduzida (apenas 3 missas apresentam um "guiam»), nas obras de Francisco Garro (1609). Paralelamente, os compositores de Santa Cruz de Coimbra, 
familiarizados com uma prática instrumental aplicada por sistema nos seus vilancicos, ou cançonetas, adotaram naturalmente formas convencionais de acompanhamento instrumental. São significativos os 4 Responsórios de Natal de D. Pedro da Esperança (? - 1660) nos quais a parte solística do versus é acompanhada por um violino, um fagotilho, um baixão e o chamado guião. Ao mesmo tempo a corrente de um estilo renovado entrava em Portugal, mercê da biblioteca de música dos Duques de Bragança, que muito terá servido ao jovem João Lourenço Rebelo: de facto a sua obra polifónica impressa em Roma em 1657, demonstra já claramente a introdução da linha barroca, que terá chegado mesmo ao "colossal style» na missa a 39 vv que, segundo a Primeira Parte do Catálogo da Biblioteca de Música, se encontrava na Biblioteca Real. A alternância sistemática de solistas e de instrumentos, alguns pré-definidos, nas obras policorais de Rebelo são, deste modo, a confirmação da introdução em Portugal do stile moderno, já na primeira metade do século XVII. Pelo contrário, com a afirmação plena das escolas de Évora, sucessivamente dirigida, depois de Mendes, por Magalhães, António Pinheiro, etc, e de Lisboa, fundada e dirigida, por Duarte Lobo, ficará na história quase só a policoralidade, com as missas e motetes a 8 e mais vozes de Lobo, de Manuel Cardoso e, menos, de Magalhães.

A opinião, segundo a qual Duarte Lobo depende mais que nenhum outro do estilo palestriniano, faz sentido mas não se pode dizer que os restantes compositores da escola de Évora na sua preferência pelo stile antico, fossem muito diferentes (Alvarenga 2004: 30-31). Sabe-se que todos estes compositores cultivaram insistentemente a técnica da missa paródia, utilizando, para o efeito, motetos de Palestrina, Guerrero ou Victoria (Rees 1997-98). O CF foi ainda utilizado, sobretudo por Fr. Manuel Cardoso, muito mais com o intuito de demonstração intencional de domínio técnico, como é o caso das 6 missas Ab initio et ante saecula; o mesmo se diga da utilização de processos mais arcaicos como a utilização em missas de temas musicais e bi-textuais ininterruptamente repetidos ao longo de todas as partes das Missas, como é o caso da Missa Miserere mibi Domine e da Missa Filipina (Cardoso 1991). Apesar de tudo, discípulos importantes da escola de Duarte Lobo, como João Álvares Frouvo, Gonçalo Mendes Saldanha, Manuel Machado e outros, afirmarão com autoridade a adoção da policoralidade que, sobretudo na produção 
variamente acompanhada de João Lourenço Rebelo, se credenciam como expoentes de barroco inicial na música sacra portuguesa de seiscentos.

A pouca música que se conhece em Portugal nas primeiras décadas do século XviII não deixa de acusar a técnica do stile moderno, no que se refere à policoralidade e à adoção do BC. É o caso de Henrique Carlos Correia, um compositor ativo em Coimbra antes de professar no Convento de Palmela. D. João V é justamente considerado o grande mecenas e promotor das artes e da Música. Como naquelas, o seu gosto musical moldou-se segundo o estilo italiano. O envio de músicos estagiários para Itália, e o convite endereçado a Domenico Scarlatti (1685-1757) que em 1719 chegou a Lisboa, onde permaneceu com interrupções até 1729 , constituiu o princípio de nova era na prática musical portuguesa: a adoção do italianismo musical que se prolongaria por mais de um século. Ao monarca interessava o nivelamento de Lisboa com Roma, como forma de restaurar a imagem de Portugal na Europa. Mais que um estilo de Música propriamente dito, o que o interessava era o diferente do tradicional, fosse ele o cantochão - pelo qual pretendeu introduzir em Portugal o gregoriano à maneira de Roma, através de cantores e mestres como Giovanni Giorgi (?-1762) - ou a mais teatral das músicas de igreja. O facto é que os estagiários João Rodrigues Esteves (c. 1700-c. 1750), Francisco António de Almeida (1702-1755) e António Teixeira (1707-1759), tendo regressado a Portugal, ensaiaram a música que ouviram e compuseram na Itália: o concertato alla romana, com grandes coros homófonos ou em fugato e alternância de solos, ou com o concertante propriamente dito em que, à alternativa de coro, solistas, se juntava também o acompanhamento cada vez mais sofisticado de uma ou mais orquestras. Se não se conhece ainda documentalmente muita música em Portugal - há certamente mais do que se pensa - existem também notícias de grandes realizações como são os grandes Te Deum de fim de ano, no dia de S. Silvestre.

O certo é que a grande música sacra setecentista viveu em Portugal uma época de ouro na dependência do gosto italiano, produzindo-se obras concertantes de grande vulto, de que são expoente máximo a Missa a 8 de João Rodrigues Esteves, o Te Deum a 8 voci concertato com Trombe, Obuè, Flauti, Violini, Corni da caccia, Tímpano e Salterio de Francisco António de Almeida e ainda o Te Deum de fim de ano (1734), para 8 solistas, 20 vozes e grande orquestra de António Teixeira. 


\section{Singularidades}

Santiago Kastner, um musicólogo insuspeito na matéria, afirmava em 1982 um "corpus peculiar» na polifonia vocal e sacra portuguesa (vd epígrafe deste trabalho). Será que hoje, estabelecidas as raízes de uma verdadeira Musicologia portuguesa, o distinto professor repetiria o mesmo? Será que o corpus da música sacra portuguesa, na época da polifonia e não só, tem algumas singularidades que a diferenciem, ligeiramente embora, da música congénere praticada em Espanha e na Itália? Não é fácil a resposta mas nem por isso se justifica que a dificuldade obstrua a razão, pelo que sempre vale a pena apontar algumas pistas que possam facilitar um diagnóstico.

No capítulo do cantochão existe uma tradição genuinamente portuguesa. Ela é muito clara no modelo do canto litúrgico da Paixão (Cardoso 2002 e 2004) dado à imprensa por Diogo Fernandes Formoso, em 1543, declaradamente segundo o costume da Capela Real portuguesa e a mando do Rei D. João III. Sabe-se que esse mesmo modelo melódico, de resto detetado pela primeira vez num manuscrito alcobacense do século xv (P-Ln Alc. 167), foi seguido por mais três passionários impressos (vd. supra), por outros impressos genéricos (v.c. Arte Mínima, 1685, de Manuel Nunes da Silva) e por vários manuscritos existentes por todo o país e que só foi substituído pelo primeiro passionário more romano impresso em Lisboa, 1732, em plena conversão portuguesa ao italianismo musical (Cardoso 2006). Além disso, sabe-se pelo menos de uma prática cantochanesca reivindicada como própria pelos Cónegos Regrantes de Santo Agostinho do Mosteiro de Santa Cruz de Coimbra. Efetivamente, no Capítulo Geral celebrado em Coimbra em 1575, ficou exarado o seguinte, com sublinhados nossos:

«Primeiramente prouendo em o officio diuino açeitamos o breuiario romano [...] [75v] e pello mesmo modo açeitamos o missal nouo que o sancto padre promulgou, exceito os cantos que serão conforme ao uso de nossa congregação [...] E o preçessionario, toairo e cantos que tem feitos o padre dom vicente outro si açeitamos. E o todo sobre dito queremos que se guarde inteiramente em toda nossa congregação. E mandamos ao padre geral que castigue grauemente todo aquelle que achar que muda algum ponto 
ou do toairo ou do processionario, ou de qualquer outros cantos que por nos forão açeitados. Porem usaremos daqui por diante dos prefacios antigos e doutros alguns não. E mandamos ao padre geral que o mais sedo que poder mande dar copia aos mosteiros de todos estes cantos, e faça imprimir logo as constituições todas que andam espalhadas per todas as partes. E o mesmo farão ao ordinario conforme ao que elle com os padres que escolher pera o conformar com o missal e breuiario, ordenar.» (p. 75v) "Definições e apontamentos do capitolo geral que se celebrou em o nosso mosteiro de Santa cruz de coimbra em o anno do Senhor de 1575" (Torre do Tombo, Santa cruz de Coimbra, maço 2, $\mathrm{n}^{\circ} 1$ ).

De facto o Ordinário dos Canónicos Regulares... publicado em 1579 é explícito: «E todos os cantos, assim do breviário como do missal que se cantarem em nossos coros, e toario que se guardar, sejam os que ora usamos, que o capítulo geral aceitou, e não outros.» (Ordinário 1579: p. 10).

A este documento podemos juntar a música de manuscritos de Santa Cruz com diferenças evidentes no accentus monológico, sobretudo na sua dimensão mensural (Cf MM 56, 69, 200). Deste modo aquilo que por musicólogos portugueses era tido como abuso e desvio de "Vocalizos próximos de árias", pode e deve ser revisto como tradição genuína, neste caso de Santa Cruz: já no caso do MM 37, pode verificar-se uma «exact manner of performance for each of the categories of chant it contains... and there are numerous examples of the use of void mensural notation providing exact indications of rhythm» (Rees 1995, 257).

Mas não são apenas os manuscritos deste Mosteiro crúzio que acusam inovações na prática do canto gregoriano: na Biblioteca Geral da Universidade de Coimbra, e provenientes da Sé local, existem também manuscritos de cantochão com as mesmas características (cf MM1 e MM 223), o mesmo se podendo afirmar acerca de manuscritos existentes em outras localidades. Parece, pois, poder aceitar-se que a Igreja em Portugal praticou um canto gregoriano com alguma singularidade, o que corresponde, como é sabido, à postura respeitadora dos Padres do Concílio de Trento, quando remeteram para os Sínodos Provinciais a determinação exata das melodias (...deque in his canendi seu modulandi ratione...), que deveriam ser executadas nos 
ofícios divinos (Sessio XXIV, Decretum de Reformatione, Caput XII, apud Weber 1996, 155).

Poder-se-á dizer o mesmo da polifonia sacra? Os Crúzios não podiam ter argumentado da mesma maneira ao decreto papal: a polifonia não existia certamente no mosteiro há mais de duzentos anos. O que significa que a dependência exterior foi muito mais forte no campo da prática contrapontística, como res scripta: «deve-se cantar apenas o que está escrito que se deve cantar....». Não parece ter havido inovações de tomo na técnica polifónica. Mesmo assim, e continuando em Santa Cruz, vale a pena recordar o depoimento do Doutor Martin Azpilcueta Navarro, consignado na Crónica de D. Nicolau de Santa Maria:

«... estando muitos anos depois em Roma, no tempo do Papa Pio V, foi consultado pelos Eminentíssimos Cardeais da Sagrada Congregação dos Ritos, se era bem que houvesse música de canto de órgão na Igreja de Deus. Respondeu: Que era de parecer que houvesse música de canto de órgão na Igreja, com condição que cantasse com a perfeição com que se cantava no Mosteiro de Santa Cruz de Coimbra em Portugal, aonde os Cónegos daquele mosteiro cantavam com tal pureza, clareza e distinção, que de todos era entendida a letra das Missas e do mais Ofício divino.» (Apud Pinho 1981: 34-35).

Esta propriedade da polifonia crúzia é notória para quem presta alguma atenção ao seu canto. Tinham, pois, razão os Priores de Santa Cruz quando exigiam que a letra dos motetos fosse aprovada antes de ser posta em música: «E queremos que a letra dos motetos novos, primeiro que se cante, seja vista e aprovada pelo Prior..." (Ordinário, o.c.: p. 10v). O respeito pelo texto sagrado, ou se quisermos a relação texto-música na polifonia de Santa Cruz é verdadeiramente uma nota característica da mesma, podendo ser considerada singular na prática universal, em que a música impôs a sua estética ao interesse litúrgico do texto.

Ainda no século xvi, é bem possível aceitar a técnica da composição do Próprio da Missa, tal como aparece no Liber Introitus 1615 (ms 967 do Arquivo Distrital de Braga) quase todo da autoria de Miguel da Fonseca, isto é, um contraponto quase visual baseado num CF inteiramente constituído, em valores 
iguais, pela melodia gregoriana correspondente à rubrica em causa, como uma verdadeira singularidade da igreja de Braga: afinal, havendo mais exemplos semelhantes deste tipo de polifonia em outros arquivos portugueses, são raros os exemplos desta polifonia no resto da Europa. "O Liber introitus constitui uma das raras fontes quinhentistas de polifonia sacra que conferem um tratamento polifónico sistemático aos textos do proprium Missae fundado no respetivo cantochão» (Alvarenga o.c.: 50).

São inovadoras ainda algumas formas de polifonia. Não falando na liberdade de aplicação do instrumental na música dos responsórios de Natal, como fez D. Pedro da Esperança, a aplicação da polifonia a certos versos da Paixão, aparece como grande inovação na Península, na originalidade e, sobretudo, na qualidade e insistência no seu uso, bem documentado na música de Santa Cruz de Coimbra. Trata-se da composição a três vozes de alguns ditos da Paixão, não apenas frases de Cristo, que deveriam ser cantadas pelos três diáconos cantores da Paixão. Alguns versos da Paixão eram, assim, enfatizados através da polifonia, em correspondência a uma intenção espiritualista própria de quem via na Cruz o emblema da Ordem de Santo Agostinho (Cardoso 2006 e 2010).

Passando ao lado dos vilancicos barrocos, essa forma de polifonia paralitúrgica que tanto motivou a devoção dos portugueses pelo menos até 1723 , recorde-se a ênfase dada aos célebres Te Deum de fim de ano, com a presença da corte e de toda a sociedade civil nos quais a música, em verdadeira macro--forma de Sinfonia (Abertura), O Salutaris hostia, Te Deum e Tantum Ergo, por vezes a dois coros e duas orquestras, desempenhava, no seu aparato e teatralidade, um papel notável de representação do poder. A comprovar a unidade destes grandes Te Deum, para além do frontispício das próprias partituras, sirva o exemplar de Sousa Carvalho de 1792, o qual, na sua Abertura sinfónica em forma-sonata, apresenta os temas tratados na peça O Salutaris, que servia de introdução litúrgica ao Te Deum propriamente dito. Não se conhecendo outra obra unitária de tal alcance no resto do mundo (Cardoso 2009), e conhecendo-se em Portugal pelo menos nove partituras diferentes com aquela grande forma, que fez tradição em setecentos, desde o Te Deum de A. Teixeira (1734) ao último de João de Sousa Carvalho (1792), temos aí certamente uma singularidade da música sacra portuguesa. 
E a música de Mafra? É singular não apenas o cantochão simplesmente acompanhado ao órgão, nota a nota (Santo António 1761). Verdadeiramente notável em Mafra foi a execução do grande reportório litúrgico com um estilo concertante de vários coros e com acompanhamento de até seis órgãos, durante o primeiro quartel do século xix. A existência de seis instrumentos homogéneos numa mesma igreja é um facto singular, porventura único no mundo católico (Vaz 2012: 25), mas o notável é que existem ainda as partituras para efetivos corais masculinos e com acompanhamento de dois, quatro ou seis órgãos, que serviram historicamente na Liturgia de Mafra. João Azevedo (1985), depois de catalogar segundo as normas do RISME grandes composições ainda bem conservadas na Biblioteca de Mafra, de João José Baldi (1770-1816) a Marcos Portugal (1762-1830), refere o grande efeito que devem ter produzido, citando Eusébio Gomes: "Cantou-se hoje a Missa de Baldi couza estrondoza" (Azevedo 1985: 187). Embora já numa época posterior ao barroco, mas ainda antes da afirmação romântica, o sentido do colossal na música poucas vezes terá sido tão pleno como naquela celebração litúrgica. Felizmente é possível hoje, restaurados que estão todos os órgãos da basílica da Mafra, sentir a experiência única de uma tal música.

\section{Conclusão}

No universo da música sacra dos séculos xvi ao xviII, é grande o património português nas suas dimensões de cantochão, polifonia e música concertante. Se na espécie de canto gregoriano é possível detetar características próprias, não apenas no que respeita a reportório, mas também na própria forma de o executar, é na música polifónica e sobretudo na grande música concertante setecentista que brilha intensamente o tesouro da música sacra portuguesa. Singular, a música sacra portuguesa dos séculos xvi a xvIII? Foi-o, certamente, em algumas espécies inusitadas no resto do mundo: na monodia do canto litúrgico da Paixão, em alguns dos versos polifónicos da Paixão, no grande $T e$ Deum de fim do ano setecentista e ainda na música de Mafra.

Considerando embora que, no mundo da técnica musical do Ocidente, Portugal não criou nada de essencialmente novo - o canto gregoriano foi 
imposto na Península, as polifonias devem a sua técnica às correntes neerlandesa e italiana e o estilo concertante é radicalmente italiano -, é certo que aqui se afirmaram estilos e formas que peculiarizam alguma da sua grande música sacra. Pode assim dizer-se que Portugal não é simplesmente um reduto cultural em que a música sacra se cristalizou no seguimento frio dos grandes modelos e dos grandes centros de produção musical europeia: aqui se afirmou decididamente o gosto por uma música sacra renovada dentro de uma fidelização básica à música saída de Roma, ou no mínimo permitida pelo centro da Cristandade. As singularidades pequenas ou grandes da música histórica em Portugal são matéria bastante para dignificar o país e fazê-lo respeitar no concerto das nações de tradição cristã.

\section{Bibliografia}

Alegria, José Augusto (1973), História da Escola de Música da Sé de Évora. Lisboa: Fundação Calouste Gulbenkian.

Alegria, José Augusto (1983a), Frei Manuel Cardoso compositor português, 1566-1650. Lisboa: Instituto de Cultura e Língua Portuguesa.

Alegria, José Augusto (1983b), História da Capela e Colégio dos Santos Reis de Vila Viçosa. Lisboa: Fundação Calouste Gulbenkian.

Alegria, José Augusto (1989), Biblioteca do Palácio Real de Vila Viçosa: catálogo dos fundos musicais. Lisboa: Fundação Calouste Gulbenkian.

Alegria, José Augusto (2004), «Da Fundação aos Mestres Polifonistas e Legado» in Escola de Música da Sé de Évora. Évora: Casa do Sul, pp. 11-25.

Alvarenga, João Pedro d' (1988), «A Música Litúrgica na Sé de Braga no Século xvi: Observações sobre o Conhecimento Actual» in Boletim da Associação Portuguesa de Educação Musical, $\mathrm{n}^{\circ}$ 58, pp. 38-47.

Alvarenga, João Pedro d' (2002), Estudos de Musicologia. Lisboa: Edições Colibri Centro de História da Arte da Universidade de Évora.

Andrade, Isabel Freire de (1992), «Impressos musicais em Portugal do séc. xvi aos fins do séc. XviII" in V Centenário do livro impresso em Portugal 1487-1987: Colóquio sobre o livro antigo. Lisboa, Biblioteca Nacional, pp. 163-173.

Azevedo, João. M. B. de (1985), Biblioteca do Palácio de Mafra: Catálogo dos Fundos Musicais. Lisboa: Fundação Calouste Gulbenkian.

Borges, Armindo (1986), Duarte Lobo (156?-1646): Studien zum Leben und Schaffen des portugiesichen Komponisten. Regensburg: Gustav Bosse Verlag 
Cardoso, José Maria Pedrosa (1991), "A Missa Filipina de Fr. Manuel Cardoso (1566-1650)», Revista Portuguesa de Musicologia, 1, pp. 193-203.

Cardoso, José Maria Pedrosa (2002), «A singularidade dos Passionários impressos em Portugal no séc. XVI", Revista Portuguesa de Musicologia, 12, pp. 35-66.

Cardoso, José Maria Pedrosa (2004), "Die Frage der liturgischen Passionsmusik in Portugal vom 16. bis 18. Jahrhundert» in Cantus Planus, pp. 871-882.

Cardoso, José Maria Pedrosa (2006), O Canto da Paixão nos Séculos XVI e XVII: A Singularidade Portuguesa. Coimbra: Imprensa da Universidade.

Cardoso, José Maria Pedrosa (2009), "O grande Te Deum barroco na Igreja de São Roque» in Cidade Solidária: Revista da Santa Casa da Misericórdia de Lisboa, $\mathrm{n}^{\circ} 22$, Ano XII, pp 142-151.

Cardoso, José Maria Pedrosa (2010), "Música da Paixão: a tipologia portuguesa» in Revista Brasileira de Música, v. 23/2, pp. 19-44.

Cortez, José Carlos Travassos (1992), Inventário dos Manuscritos Musicais da Biblioteca Geral da Universidade de Coimbra. Dactilografado.

Fernandes, Cristina (2009), O sistema produtivo da música sacra em Portugal nos finais do Antigo Regime: a Capela Real e a Patriarcal entre 1750 e 1807. Dissertação de Doutoramento, Universidade de Évora.

Joaquim, Manuel (1953), Vinte livros de música polifónica do Paço Ducal de Vila Viçosa. Lisboa: Fundação da Casa de Bragança.

K[astner], M[acário] S[antiago] (1982) «Nota» in Antologia de Polifonia Portuguesa 1490-1680. Lisboa, Fundação Calouste Gulbenkian (Portugaliae Musica, XXXVII), p. XXV.

Lessa, Elisa Maria Maia da Silva (1992), A actividade da Sé de Braga no tempo do Arcebispo D. Frei Agostinho de Jesus. Coimbra (dissertação de mestrado)

Lopes, Rui Cabral (2007), "Religiosity, power and aspects of social representation in the vilancicos of the Portuguese Royal Chapel» in Tess Knighton, Alvaro Torrente, Devotional Music in the Iberian World: The Villancico and related Genres, pp. 199ss.).

Marques, João Francisco (2000), «Orações e devoções» in Carlos Moreira Azevedo (dir.) História Religiosa de Portugal. Lisboa: Círculo de Leitores, vol. 2, pp. 603-670

Mendes, António Rosa (1993), "A vida cultural» in José Mattoso, História de Portugal: Terceiro Volume No Alvorecer da Modernidade (1480-1620). Lisboa: Círculo de Leitores, pp. 375-421.

Ordinario dos Canonicos Regulares... (1579). Lisboa: S. Vicente de Fora, cap. 3.

Pinho, Ernesto Gonçalves de (1981), Santa Cruz de Coimbra Centro de Actividade Musical nos séculos XVI e XVII. Lisboa: Fundação Calouste Gulbenkian.

Rees, Owen (1995), Polyphony in Portugal c. 1530 - c. 1620: Sources from The Monastery of Santa Cruz, Coimbra. New York \& London: Garland Publishing. 
Rees, Owen (1997/98), «Some observations on parody Masses by Magalhães, Cardoso and Garro", Revista Portuguesa de Musicologia, 7-8, pp. 7-30.

Saraiva, José Hermano (1983), "Anos sombrios» in José Hermano Saraiva (dir) História de Portugal, Vol. 2. Lisboa: Publicações Alfa, pp. 475-490.

Santo António, Fr. José de (1761), Acompanhamento de missas, sequencias... Lisboa: no Mosteiro de S. Vicente de Fora.

Serrão, Joel (1985), «Decadência» in Joel Serrão (dir) Dicionário De História de Portugal, II vol., Porto: Figuerinhas, pp. 270-274.

Vaz, João (2012), "Os seis órgãos da Real Basílica de Mafra», in Os Seis Órgãos da Basílica da Mafra. Lisboa: RTP Edições.

Weber, Edith (1996), Histoire de la Musique Française de 1500 a 1650. Paris: Sedes. 
Maria Adelina Amorim ${ }^{57}$

Associação de Cultura Lusófona - Universidade de Lisboa

Vitor Serrão ${ }^{58}$

Instituto de História de Arte - Universidade de Lisboa

\section{AS REPRESENTAÇÕES DA MÚSICA NA ARTE PORTUGUESA: CONTRIBUTOS PARA UM BANCO DE DADOS ICONOGRÁFICO}

\section{Sensibilização para um problema de património artístico nacional}

Desde muito cedo, tanto na sua produção científica como na sua actividade de docência, a Prof. Maria Augusta Barbosa (n. 1912) sentiu quão importante era o património artístico português no que toca às representações musicais e pôs a tónica na necessidade de se desenvolverem mais e melhores estudos que permitissem dar a conhecer esses acervos, quer no território continental, quer nos interfaces da presença portuguesa no mundo.

$\mathrm{Na}$ realidade, percorrendo os livros de arte, os catálogos de grandes exposições, os inventários artísticos (como o da Academia Nacional de Belas Artes

57 M.A.A. - Presidente da Associação de Cultura Lusófona da Universidade de Lisboa. Aluna da Prof. Maria Augusta Barbosa, quer durante a licenciatura em História, quer no Mestrado em História e Cultura do Brasil, em que a Querida Mestre leccionou a cadeira e o seminário de História da Música e História da Música no Brasil Colonial, respectivamente, vem deixar um preito de homenagem verdadeira e sentida a uma das pessoas maiores que encontrou no seu percurso académico e pessoal, a que ficou ligada por profundos laços de Amizade, que tornaram os cerca de vinte e cinco anos de convívio pessoal e quase quotidiano, um tempo profícuo de aprendizagem de Vida, de rectidão, de carácter, de profissionalismo, de dedicação às Artes e ao Saber, sendo ao mesmo tempo portadora de uma Humildade que só os Grandes Mestres possuem, e só os Iluminados cultivam. Maria Augusta Barbosa é indubitavelmente, as duas coisas. A autora deixa o mais reconhecido, íntimo, profundo e eterno OBRIGADO.

58 V.S. - Professor Catedrático. Instituto de História da Arte da Faculdade de Letras da Universidade de Lisboa. Colega de Maria Augusta Barbosa durante o tempo da sua leccionação na Faculdade de Letras da Universidade de Coimbra, compartilhando quase semanalmente o mesmo comboio que os levava de Lisboa para a cidade coimbrã, onde houve oportunidade de trocar experiências, saberes e preocupações comuns pelas Artes a que têm dedicado a sua vida profissional e pessoal. 
e os das comissões de arte sacra das Dioceses), as monografias e estudos parcelares, etc etc, facilmente se verifica, pela simples observação das imagens reproduzidas, que a arte portuguesa, desde a Idade Média até à contemporaneidade, não se alheou da realidade musical, abrindo-se à representação de instrumentos musicais, de grupos de músicos e cantores e, em casos mais raros mas não menos explícitos, à alegorização da própria Música como esteio das Artes Liberais.

São milhares as representações que podem ser assinaladas: a pintura a óleo e a fresco, o azulejo, a escultura e a talha, a iluminura, a ourivesaria, o mobiliário, os têxteis, os couros lavrados e, inclusivamente, artes decorativas como os embrechados e os estuques, abriram-se à presença de temas musicais e à figuração dos seus atributos e instrumentos, multiplicando a sua figuração, do século XII até aos nossos dias, em vários materiais e suportes, consoante a evolução dos estilos, a maior ou menor capacidade de observação dos temas e a importância relativa das representações em determinados contextos iconográficos religiosos, alegóricos ou profanos.

Conforme reconheceu sempre a Prof. Maria Augusta Barbosa, na sua docência e no seu diálogo aberto com os que com ela tanto privaram, com essa sua especial sensibilidade para sentir a Música em todas as suas manifestações - eruditas e populares, europeias e extra-europeias ${ }^{59}$ - o papel das

59 Haveria muito para desenvolver a este respeito numa pesquisa dos testemunhos que deixou nas suas aulas, nos seus acompanhamentos científicos e orientações académicas ou, por exemplo, nas visitas de estudo em que acompanhava os alunos. Ficaram célebres as idas ao Palácio Convento de Mafra, onde disciplinava os estudantes a toque de uma pequena sineta que sempre a acompanhava, e em que era a primeira a chegar aos carrilhões depois de se terem percorrido quilómetros de corredores do actual Museu. Do mesmo modo, restam nas memórias dos seus alunos as visitas a Conímbriga, a Évora, aos Capuchos em Sintra (era bom ouvir o silêncio; perceber as escalas físicas e humanas, a grandiosidade da natureza, o valor do recolhimento para fruir o som, o breve bater de asas, o doce murmurar da água, o chilreio, o ferrolho, a porta velha... Tudo eram sons que nos eram transportados. Bastava ouvir. Mas nada que se comparasse a um desabar de uma violenta tempestade, sonoras, pujantes e brutais embates de nuvens carregada de som e brilho. E o mar... o mar batido, vigoroso e poderoso do Guincho, da Boca do Inferno... o vento do Cabo da Roca, a carga hierofânica do Cabo Espichel e o abrigo do Santuário de Nossa Senhora do Cabo. Tudo servia ao mesmo propósito pedagógico, tudo eram instrumentos, metodologias, quase um proselitismo para convidar os aprendizes a perceber que a Música é uma Arte Maior, universal. Dava tanta importância à mais complexa, acabada, exemplar composição e interpretação - era profundamente crítica e de um fino e inteligente humor - como a um xilofone ou a um chocalho. Impressionava-se tanto com a execução de uma renomada orquestra, como se enchia de ternura perante uma pequena escultura de madeira de um homem tocando marimba. Pegava nos instrumentos com um grau de veneração igual, fosse uma lira-apolo, uma harpa, um violoncelo, uma viola de bracio ou fosse uma banza de socopé, um mpungui, uma Koré ou um apito. Dava a mesma importância aos grandes organeiros, aos 
artes abriu-se sempre à presença da música e é por isso que impõe sempre uma disponibilidade maior de observação integral por parte dos estudos das Ciências Musicais. Seja a decoração da arquitetura clássica e medieval, a imaginária em madeira, terracota e pedra da Idade Moderna, a pintura a óleo, a têmpera e a fresco do Renascimento e do Maneirismo, o azulejo do Barroco, a paramentaria, o mobiliário, as pratas e alfaias litúrgicas, o estuque, e tantas outras componentes que século a século integraram os músicos e a música como partes essenciais da representação sacro-profana, tudo no campo das artes impõe um olhar atento, não formalista e não meramente histórico-documental, pois esse campo tem em si valências de longo curso.

A metodologia da História da Arte não se esgota, como bem se sabe, na via da investigação dos arquivos, ou na via da análise laboratorial de peças, mas impõe sempre o estudo estilístico e comparativo, iconográfico e iconológico das obras de arte (de todas as obras de arte) de per si. Um inventário exaustivo das representações musicais só faz sentido, nas suas palavras, se integrado numa visão globalizante, em que não é só a peça que conta, e o modo como o instrumento foi tratado pelo autor, mas as razões que o levaram a fazê-lo no contexto de uma encomenda precisa e com públicos bem definidos.

No âmbito de uma disciplina científica como é a História crítica da Arte, que visa, à luz dos seus próprios conceitos e modos de fazer, dar a conhecer melhor as obras de arte, estimular o ato da suas leitura na sua componente de integralidade, saber avaliá-las como produtos específicos de conjunturas, épocas e situações do tempo histórico (e além do tempo histórico), é tarefa dos estudiosos que a pratiquem saber situá-las em contexto, entendê-las como objectos vivos dotados de fascínio duradoiro e como testemunhos estéticos dotados de carga trans-memorial, a fim de poder justamente unir, tanto quanto for possível, as componentes do gestor das artes com a do historiador-crítico

mestres fabricadores dos mais preciosos violinos, como levava os alunos à oficina do artesão bracarense Domingos Machado onde ficavam horas a observar a mestria das sua mãos na fabricação manual da violas típicas como a Campaniça Alentejana, a Beiroa, a Braguesa, a da Terra a da Madeira, a Toeira de Coimbra, etc. Do mesmo artista saíam guitarras, bandoliras, banjolins, banjos, bandolas, bandolocelos ou cavaquinhos de Lisboa ou do Brasil... Tudo era apresentado com o mesmo grau de rigor, tudo era elevado ao grau de obra-prima, desde que o artesão. Mestre, artista, músico, intérprete, compositor fizessem a sua arte com os sentidos e o apuramento que depois a técnica e a prática e a disciplina treinavam e aperfeiçoavam. 
e com a do connoisseur de obras artísticas, sem esquecer que muitas dessas peças são, também, objetos de culto e, por isso, mantêm incólume as suas dimensões de intermediários de fé, não deixando por isso de ser também e sempre obras de arte.

Estudar-se a música no contexto da sua representação em obras do Património artístico nacional impõe sempre o reconhecimento destas vertentes.

\section{Dimensões da Música na e com as obras de arte}

A dimensão trans-contextual dessa música eternizada na pedra, na madeira ou no barro pelo escopro e pincel dos artistas apresenta-se, fascinante, nas muitas pinturas das Assunções da Virgem pintadas pelas oficinas portuguesas do século XVI.

O tema exaltava o triunfo da fé e, por isso, a presença dos anjos músicos era um imperativo da iconografia. Uma tábua quinhentista como a da igreja matriz de Sardoura (Lamego), por exemplo, estudada pelo musicólogo Mário de Sampayo Ribeiro nos anos quarenta do século passado com toda a atenção, num ensaio pioneiro sobre as representações musicais na nossa pintura antiga, veio demonstrar esse cuidado extremo da representação, com a sua dimensão contemporânea muito acentuada, mas revelou, também, que em muitos dos casos se revelam distintas atitudes dos artistas face ao verismo das peças observadas (neste caso a da igreja de Sardoura, onde os anjos tocam charamelas, sacabuxa e órgão portátil, ressoando uma espécie de sinfonia que envolve a Virgem Maria, acima do túmulo e dos Apóstolos assistentes). ${ }^{60}$

Mas nem sempre as representações religiosas na pintura, mesmo quando aparentemente cuidadas no seu aspecto funcional, revelam um conhecimento das fontes, e apenas e só uma derivação de modelos (por via de gravuras ou por via do conhecimento de outras obras) - e esse é um aspecto absolutamente a considerar nos nossos estudos. ${ }^{61}$

\footnotetext{
60 M. de S. Ribeiro 1943

${ }^{61}$ Idem, op. cit.
} 
Mas não haja dúvidas que é notável a quantidade e diversidade de instrumentos que se apresentam nos retábulos de culto e nos frescos pintados do século xvi (mais do que alguma outra época), tanto da chamada música baixa como da música alta, num exercício de conjugação entre erudição e populismo, entre festa cortesã e rural, entre dimensão profana e espiritual. Vemos aí representados, entre santos de altar ou no contexto de milagres e de cenas do hagiológio cristão, moços de câmara e anjos, jograis e bailadeiras, pastores de gaita-de-foles e menestréis, ouvimos quase o som dos alaúdes, da harpa, da rabeca, da viola de gamba, da charamela, do órgão, da guitarra, do saltério, da sanfona, das pandeiretas, dos guizos, dos tambores, dos címbalos, das trompetas e sacabuxas, etc etc, e chegamos a sentir o frémito da música que nos chega registada em pautas reconhecíveis (e reinterpretáveis), como sucede em tábuas do pintor Garcia Fernandes (no Mosteiro de Ferreirim), do famoso Vasco Fernandes, o Grão Vasco (na igreja de Aldeia Viçosa, Guarda) ${ }^{62}$, do mais modesto pintor Bastião Lopes (em Nossa Senhora de Brotas, Mora) (Fig.6) ${ }^{63}$ ou do pintor flamengo, já maneirista, Francisco de Campos (Évora), entre outros pintores quinhentistas que tiveram especiais cuidados nas representações da componente musical em cenas religiosas destinadas a grandes comunidades de devotos... E na igreja matriz de Veigas (Bragança), a capela-mor deixa ver, pintado a fresco no fim do século xvi, um tocador de alaúde em pose profana, dando uma nota de festividade popular ao presbitério, lugar central do vulto numa comunidade como essa pequena aldeia transmontana... O mesmo se passa nas orquestras ao vivo, digamos assim, em ciclos de azulejos barrocos do início do século xvıII, seja no claustro do Convento agostinho da Graça de Torres Vedras (pelo mestre P.M.P., c. 1720) ou no atual refeitório do Convento paulista da Serra d'Ossa (por António de Oliveira Bernardes, c. 1710) (Fig. 7).

Este espectáculo da música que se eterniza na representação dos artistas, tanto eruditos como populares, é perenizado ao longo dos séculos e não encontra só o acento maior na pintura do século xvi (como passou a pensar-se numa dimensão muito redutora. Quando admiramos um belíssimo painel

62 V. Serrão 2001

63 Esta tábua (Fig. 6) foi dada a conhecer por Túlio Espanca no Inventário artístico de Portugal. A atribuição ao pintor eborense Bastião (ou Sebastião) Lopes carece ainda de contraprova. 
de azulejos com um passo do Cântico dos Cânticos pintado por António de Oliveira Bernardes, cerca de 1710, num dos espaços monacais do Convento de São Paulo da Serra d' Ossa, com a sua sinfonia vibrante de instrumentos representados com detalhe de realismo, atesta-se o quanto o encanto da música e o fortalecimento da dimensão espiritual andaram sempre de mãos dadas, num exercício de encantações a que o talento dos melhores artistas deu corpo tangível. ${ }^{64} \mathrm{~A}$ arte do Azulejo português, aliás, possibilitou alternativas importantes à representação musical, já que esta modalidade teve, para além da componente religiosa que o seu uso em tempos de Contra Reforma acentuou, uma poderosa dimensão profana, cortesã, cenográfica e venatória, muito bem tratada, por exemplo, por José Meco. ${ }^{65}$

Nem sempre as representações musicais surgem como reforço legitimador ao discurso mariano e cristológico. Também contribuem para acentuar o sentido da pedagogia e a ardência da alegoria moral. Quanto vemos, no Paço de Vila Viçosa, os dois grandes tetos das Salas da Música, pintados nos anos 30 do século XVII por ordem de D. João IV (ainda Duque D. João II de Bragança), com um coerente e bem desenvolvido programa em torno dos Encantos da Música - iconografia de Orfeu, triunfo da Música Profana, alegoria à Fonte de Hipocrenes e à Música vencedora da Guerra, etc - e do Cântico dos Cânticos - triunfo da Música Sacra, história de David, Jahel e Sisara, etc -, vemos como Música e Pintura se encontram em uníssono, à luz de um programa iconológico definido ao pormenor pelo futuro rei Restaurador, em catalogação plástica e devidamente paragonada das mais-valias da Música Sacra e da Música Profana, para legitimar o peso da cultura musical na corte bragantina (Fig. 9). ${ }^{66}$ Sabemos pelas fontes de corte que D. João IV, compositor de grande talento e musicólogo de projeção internacional, gostava de ver José do Avelar Rebelo pintar, e com ele discutia Pintura - mas por certo também a Música que esse artista ia representando em alegorias no teto do salão régio de Lisboa, esse desaparecido teto da Sala de Música do Paço Real da Ribeira, em Lisboa, que o terramoto de 1755 arrasou. Rui Vieira Nery estudou bem essa obra, pintada por Avelar Rebelo a mando do seu amigo D. João IV, descrevendo à luz das

\footnotetext{
64 J. Meco 1989.

65 Cf. J. Teixeira 1983 e V. Serrão 2008. Sobre D. João IV músico, cf. R. V. Nery 1991.

66 Cf. J. Teixeira 1983 e V. Serrão 2008.
} 
fontes as suas múltiplas alusões à Música na Antiguidade, além de retratos de compositores célebres como Palestrina e os portugueses Manuel Cardoso e João Soares Rebelo, o Rebelinho. ${ }^{67}$

Sem intuitos de exaustividade, lembramos como os grandes artistas europeus encontraram muitas vezes o aliado providencial na Música para comporem as suas melhores obras. Por exemplo, o célebre bolonhês Domenico Zampieri, o Domenichino (1581-1641), é exemplo do artista pictórico musical, cujo interesse pela antiga música cromática e harmónica era tão vasto que fez construir para si um cravo e uma harpa, e projectava conseguir um órgão "com todo o tipo de atónicos, cromáticos e harmónicos" para afinar as harmonias da música com as harmonias da pintura ! O esforço com que este pintor e arquitecto concebeu a 'lira barberina', que dedicou ao Papa Urbano VIII (Maffeo Barberini), o grande pontífice da Roma seiscentista, atesta essa hipersensibilidade auditiva do pintor bolonhês, exemplo acabado de artista de múltiplos empenhos criativos e receptivos, na busca da harmonização do mundo através da Música. ${ }^{68}$ Como exemplo dessa paixão partilhada pelas duas sensibilidades da alma, Pintura e Música, restam do grande pintor bolonhês Domenico Zampieri dois "quadros musicais", La Sibila de Cumas e Santa Cecília (Galeria Borghese, Roma) que tiveram como modelo a sua própria mulher, a bela Marsilia Barbetti.

Podem juntar-se a esta galeria de pintores-músicos, que se deleitavam nos duplos prazeres dos sentidos, um Verrochio, que foi a seu tempo artífice, escultor, entalhador, pintor e músico, Fra Bartolomeo, Giorgione, Rosso Florentino ou Ticiano Vecellio, que "tocava violino e viola para esparcimiento e repouso das épicas fadigas pictóricas". O próprio Leonardo da Vinci foi virtuoso no uso da lira de braço e arco, de que deu várias provas ao lado de profissionais músicos de corte. Também Tintoretto, Guido Renni, Cellini ou Salvator Rosa foram exímios compositores e intérpretes de instrumentos. Tal virtuosismo fê-los transpor para as mãos dos anjinhos tocadores das suas telas musicais, os instrumentos cujos sons os deleitavam, e com que duplamente glorificavam o Divino e o apraziam Humano.

\footnotetext{
67 R. V. Nery 1991.

68 E. Fabiani 1993.
} 
Para terminar esta breve referência a mestres pintores, lembre-se Caravaggio, que cerca de 1594-1596, ainda muito jovem, pintou aquela que viria a ser uma das suas obras-primas, O Repouso na Fuga para o Egipto (Galeria Pamphili, Roma), onde um anjo como figura central da cena toca violino a partir de uma partitura mostrada por São José, deixando-se para um plano periférico a Senhora e o Menino que dormem placidamente ao som do instrumento. O grau de precisão e conhecimento musical era tão profundo que o grande mestre Caravaggio pinta a partitura com um grau de composição perfeito, passível de ser lida por paleógrafos musicais, e interpretada, uma vez que constitui um conjunto melódico lógico e uniforme, a par de ser uma das primeiras representações gráficas, neste caso pictórica, do violino moderno com as suas especificidades próprias. ${ }^{69}$

Também El Greco, na sua casa de Toledo, se comprazia em pintar no atelier com assistência de uma companhia de músicos que tocavam para seu deleite, e o nosso obidense Baltazar Gomes Figueira (1604-1674), muito bom pintor de naturezas-mortas, era exímio como instrumentista, sendo por isso reconhecido como virtuoso nos anos de formação em Sevilha. Os exemplos multiplicam-se e basta percorrer o clássico livro Born under Saturn de Rudolf e Margot Wittkower para atestar essa fusão de interesses das artes plásticas e musicais em várias latitudes, épocas e escolas artísticas, desde a Antiguidade ao século xx.

Poder-se-iam assinalar muitos mais exemplos como os casos em apreço, recorrendo tanto a obras de arte existentes como a outras já infelizmente destruídas ou mutiladas, mas cuja memória cripto-artística (tal como na terminologia da História da Arte se denomina a realidade de indicio ou fragmento de um todo já inexistente) tem forçosamente de contar numa base inventarial exaustiva. Só com uma perspectiva global se pode cumprir um objectivo dotado destes pressupostos, e só assim se reforça a necessidade e utilidade desse corpus de iconografia musical - de que continuamos a carecer como projecto interdisciplinar de conjunto - unindo nesse esforço historiadores

\footnotetext{
69 Veja-se a obra de Benvenuto Disertori (Trento 1887 - Milão 1966) que como musicólogo, gravador, e reputado paleógrafo musical - fundou em Cremona o Instituto Cesari de paleografia musical da Universidade de Parma -, transcreveu várias músicas que aparecem representadas em pinturas antigas.
} 
de arte, investigadores de musicologia e de etnomusicologia, antropólogos e historiadores, congregados num esforço de recenseamento sem limites cronológicos ou conceptuais.

\section{Por uma Base de Dados nacional de existências e perdas}

A verdade, porém, é que ainda carecemos dessa Base de Dados exaustiva que documente as existências artístico-patrominiais-musicais (digamos assim), que as situe, que as caracterize, que as estude e identifique com o necessário rigor.

Referimo-nos (como dizia a Prof. Maria Augusta Barbosa) a uma base segura de recenseamento por onde se possa estabelecer - por exemplo - a fidelidade da representação musical em causa numa determinada pintura ou escultura, o modo como o instrumento é referenciado (e, bem ou mal, usado), a que tipo de música corresponde, etc etc. Acrescentaríamos que também a base seguida pelo artista (através da observação de visu, nuns casos, ou inspirando-se, com maior ou menor rigorismo, numa fonte gravada, noutros casos talvez mais vulgares), ou a carga simbólica tributável à integração temática em determinado contexto narrativo, são aspectos fundamentais a considerar.

Eis um caminho fascinante, para o qual a Prof. Maria Augusta Barbosa apontou caminhos e destacou a verdadeira importância da empresa. Continua hoje a ser urgente recriar as bases interdisciplinares que permitam colmatar essa lacuna de bases, reunindo antes de mais a informação múltipla colhida de inúmeros projectos e teses universitárias saídas nos anos recentes e, de seguida, estendendo a verificação identitária de espécimes ao território nacional com âmbito exaustivo, sem esquecer, também, a dimensão criptoartística das perdas. Essa será, aliás, uma das mais consistentes homenagens que a comunidade científica pode prestar à nossa centenária homenageada.

É evidente que a situação demonstra a maior actualidade, até porque existe hoje uma base de conhecimentos de que não dispunha, por exemplo um Mário de Sampayo Ribeiro ou os estudiosos da sua geração nos anos centrais do século passado, alguns deles muitas das vezes atraídos mais pelo pitoresco de uma representação de um cortejo cortesão ou de uma sinfonia de anjos num 
retábulo sacro do que, propriamente, pelo estudo das fidelidades representativas ou das razões iconológicas de uma opção criadora...

Novos equipamentos de importância apareceram entretanto, todos eles dinamizadores de novas pesquisas neste campo.

É imperioso lembrá-los, sem intuitos de exaustividade e sem receio de não referir alguns nesta breve síntese que é, sobretudo, uma homenagem à Prof. Maria Augusta Barbosa, espécie de patrona destas linhas de investigação que começam, finalmente, a ganhar forma autonomizada.

1) Por um lado, a criação do Museu da Música, gerado em 1994 por iniciativa do Instituto dos Museus e da Conservação, com a sua valiosa colecção de instrumentos e, também, de representações artísticas e documentais, com objectivo de salvaguardar, conservar, estudar, valorizar, divulgar e desenvolver o património musicológico, fonográfico e organológico português, tendo em vista o incentivo à qualificação e divulgação da cultura musical portuguesa, associando-se, nessa dimensão, ao esforço de recenseamento iconográfico musical do país. A diretora do Museu, Maria Helena Ferraz Trindade, levou a cabo em 1999 uma exposição muito valiosa de Arte e Música. Iconografia Musical na Pintura do Século $x v$ ao Século $x x$, que alargou expectativas de abordagem ao cruzar tempos distintos e olhares plurais na representação musical..$^{70}$

2) Em 2000, o Núcleo de Iconografia Musical do Centro de Estudos de Sociologia e Estética Musical (CESEM) veio estruturar estudos de gabinete de âmbito iconográfico sobre a música portuguesa através das artes, dando corpo ao projeto Images of Music - a Cultural Heritage, saído em 2006.

3) Por outro lado, desenvolveram-se de maneira significativa os estudos universitários em departamentos especializados das Universidades (Coimbra, FCSH de Lisboa, Aveiro e Évora), com a génese de uma série de dissertações, orientadas por investigadores de renome no campo da Musicologia, que nasceram, foram devidamente apoiadas e defendidas no seio dos Departamentos de Ciências Musicais dessas estruturas de ensino. Dispomos hoje de uma série de teses de pós-graduação dedicadas a esse propósito. ${ }^{71}$

\footnotetext{
70 M. H. F. Trindade (coord.) 1999

71 Cf. por exemplo, sem intuitos de exaustividade, e entre as primeiras, a tese de M. do A. Monteiro 1992 e, entre as mais recentes, S. M. da S. Duarte 2011.
} 
4) Enfim, é de destacar também a bem sucedida candidatura do Fado a Património Imaterial da Humanidade, desenvolvendo a propósito um levantamento pioneiro da guitarra portuguesa e o modo como tem sido representada no campo das artes, portuguesas e não só. ${ }^{72}$

Todos estes equipamentos, esforços e sinergias começam a pôr ênfase na importância dos estudos musicais à luz da sua representação no terreno da arte portuguesa - depois de se constatar quão original se revelava o património artístico português nesse aspecto particular em termos de existências, das mais eruditas às mais populares -, não já numa mera dimensão localizada mas com a consciência de que importa integrar esse interesse numa visão globalizadora e pluri-disciplinar.

\section{Um status quaestionis dos estudos artístico-musicais convergentes}

Terminamos com um breve panorama sobre a importância destes estudos, ainda tão embrionários no tempo de Mário de Sampayo Ribeiro e que, com a Democracia portuguesa após 1974 , tenderam a reforçar o seu papel e a ter possibilidade de crescerem, desde um estado muito residual de interesses até se constituírem terreno de eleição.

Panorama de certa marginalidade era, de facto, o tempo e as condições em que Sampayo Ribeiro pôde olhar para os Primitivos Portugueses, sem que do seu esforço se seguisse uma natural continuação de interesses. Já em 1976 o assunto estava vivo, no afã de uma situalção política que era de euforia na busca de saberes e no reforço de uma identidade cultural a reconstruir, e ganhara-se consciência tal da importância dos estudos artístico-musicais na área patrimonial, que a Direcção Geral do Património Cultural da Secretaria de Estado da Cultura iniciava, com Humberto d'Ávila como seu dinamizador maior, um projecto a que se chamou Levantamento da Iconografia Musical em Portugal e Registo de Instrumentos, que teve resultados pontuais muito interessantes. A base de dados cobriu sobretudo os museus estatais, ainda

\footnotetext{
72 Cf., por exemplo, S. Pereira 2009. Da mesma autora, directora do Museu do Fado e doutoranda em História da Arte pela Faculdade de Letras de Lisboa, cf. 2005.
} 
que o projecto não tivesse possibilidade prática de se estender ao grosso da paisagem nacional, como era sua intenção inicial. ${ }^{73}$

A iniciativa teria, de certa maneira, continuidade através do Instituto Português do Património Cultural, com direcção de João Palma Ferreira, num esforço para inventariar a iconografia musical portuguesa, que teve no Departamento de Ciências Sociais da FCSH um esforço de campo significativo ${ }^{74}$, com resultados em fichagens e, também, com ensaios de síntese, como no campo da iluminura medieval e renascentista ${ }^{75}$, ou no das representações de instrumentos nos Presépios barrocos de madeira e terracota, entre outros. ${ }^{76}$ Foi com o ensaio de Luís Henrique, Instrumentos Musicais, saído em 1988 e várias vezes reeditado ${ }^{77}$, que os estudiosos passaram a contar com uma base credível de análise e cotejo de representações.

A grande exposição coordenada por Natália Correia Guedes no Mosteiro de São Vicente de Fora em 1994, Encontro de culturas: oito séculos de missionação portuguesa, teve o especial interesse de alargar o registo das representações musicais, e a sua presença instrumental objectiva, para os espaços da lusofonia, integrando testemunhos dos espaços do antigo império português. ${ }^{78}$ Foi, nessa perspetiva, um virar de página de interesses integrados e robustecidos.

O empenho maior dos estudiosos tem enfocado com maior poder de observação, sempre, o campo da pintura dos séculos xv e xvi e é fácil perceber-se

73 Infelizmente, o processo foi interrompido, dele restando, sobretudo, os materiais de levantamento relativos aos museus nacionais.

74 De resultados parcelares, este pré-inventário produziu, p. ex., um conjunto de estudos reunidos no $\mathrm{n}^{\circ} 52$ do Boletim da Associação Portuguesa de Educação Musical, $\mathrm{n}^{\circ}$ 52, Janeiro-Março de 1987.

75 B. A. Gomes e M. J. Borges 1987.

76 M. A. Latino 1987.

77 L. Henrique 1988.

78 N. C. Guedes (coord.) 1994. Sobre a participação d Maria Augusta Barbosa na recolha, selecção, inventariação e tratamento das peças que constituíram a Secção de Música no contexto da missionação em todas as parte do antigo Império português, em que se percorreu o país de Norte a Sul, e se contactaram entidades e coleccionadores de instrumentos e documentos ligados ao tema, quer nacionais, quer internacionais, desde os museus, arquivos, centros de pesquisa, casas missionárias, etc, até a colecções do Vaticano ou outras, há ainda um testemunho a dar por um dos autores (M.A.A.) que acompanhou durante dois anos a sua Mestre Maria Augusta na fase preparatória da montagem da referida exposição, tendo em sua posse os materiais recolhidos destinados a um trabalho de maior fôlego em forma de homenagem para o conhecimento de mais esta importantíssima actividade de Maria Augusta Barbosa em prol da Arte da Música, e que, por motivos de saúde, foi impedida de terminar o texto que sairia no catálogo. 
porquê. As representações temáticas da Adoração dos Pastores e da Assunção da Virgem, muito comuns no contexto narrativo dos retábulos das igrejas e mosteiros durante o século xvi, foram especialmente adequadas para a integração de um sem-número de instrumentos musicais a fim de dar credibilidade maior aos concertos angelicais, entendidos como uma espécie de música celestial ao vivo, como Mário de Sampayo Ribeiro de há muito demonstrou, estudando algumas pinturas renascentistas com essas temáticas. ${ }^{79}$ Para este musicólogo, que abriu um campo de análise comum à História da Arte e à Musicologia dotado de futuro, os instrumentos que os pintores representavam só em certos casos eram fidedignos - e existem imensos casos desse rigorismo seguido e cumprido (que devem ser explicados à luz da encomenda), pois refletiam conhecimento direto das suas propriedades), havendo embora um sem-número de obras com simplificações na representação dos instrumentos, com incorreções de uso, etc etc. O relatório de Sampayo Ribeiro foi importantíssimo por nos dar a ver modos distintos de representação a revelar atitudes distintas por parte dos encomendantes e dos públicos.

É de destacar também, entre outros momentos de construção de um caminho de re-conbecimento do Património artístico-musical, o trabalho que em 1962 se realizou no Museu Nacional de Arte Antiga aquando da reunião da Comissão Internacional do ICOM, através de um certame sobre Temas Musicais nas Obras de Arte do Museu Nacional de Arte Antiga. ${ }^{80}$ Seguiram-se o ensaio incontornável do antropólogo Ernesto Veiga de Oliveira sobre instrumentos musicais portugueses ${ }^{81} \mathrm{e}$, numa dimensão mais pomntual de 'estudo de caso', o trabalho colectivo coordenado pelo historiador de arte Prof. Jorge Henrique Pais da Silva sobre uma obra célebre da pintura 'manuelina', o retábulo de Santa Auta (M.N.A.A.) ${ }^{82}$, com exame das representações de instrumentos e grupos musicais devida e exemplarmente tratados. ${ }^{83}$ No campo da iluminura dos séculos xv e xvı, há numerosa bibliografia dedicada ao canto

\footnotetext{
79 M. de S. Ribeiro 1943.

80 Cat. da exp. Temas Musicais nas Obras de Arte do Museu Nacional de Arte Antiga, MNAA, 1962.

81 E. V. de Oliveira 1966 ( $2^{\text {a }}$ ed. revista, 1982).

82 J. H. P. da Silva (coord.) 1972.

83 Manuel Morais e Sérgio Guimarães de Andrade ocuparam-se dessas temáticas específicas no citado estudo coordenado por Jorge Henrique Pais da Silva, op. cit., pp. 44-50.
} 
litúrgico, à polifonia, aos repertórios musicais portugueses, etc, que se abre também à leitura das representações de instrumentos e práticas de música, como é o caso dos estudos de José Maria Pedrosa Cardoso ${ }^{84}$, entre outros.

Dito isto, pensamos que o terreno está hoje sedimentado, em interesses multiplicados e metodologias experimentadas, para se estruturar a almejada Base de Dados exaustiva de iconografia musical portuguesa, base de estudo fundamental e inadiável, para cuja realização muito pugnou a Prof. Maria Augusta Barbosa.

Que esse corpus não pode ser limitada tão-só às pretensas obras-primas, mas à totalidade do património sobrevivente, é mais que certo: basta ver-se a quantidade e interesse das representações artística não eruditas (na talha dourada do Barroco beirão e transmontano, por exemplo), para se constatar que só com um cotejo alargado podem fazer sentido os dados cotejáveis.

Que a sua extensão no tempo e no espaço permite aclarar práticas no terreno, usos e gostos, perdurações memoriais e influências externas, disso não existe qualquer dúvida: basta ver-se como a presença de certos instrumentos em determinadas regiões se explica por esse destaque estatutário, digamos assim, da representação artística.

Que o interesse é múltiplo, pois ajuda a ver o grau de realismo dos artistas, também não resta qualquer dúvida, responsabilizando mais e melhor os historiadores (da arte e não só) por esse esforço colectivo.

Enfim, que esse enfoque inventarial tem de integrar a experiência lusófona, os instrumentos representados e as formas etnomusicais e de convivialidade com o outro, e o modo como tal se processou e reflectiu através das artes (o marfim, o bronze relevado, etc), eis uma dimensão fundamental a aduzir em reforço a esta Base de Dados.

\section{Bibliografia}

Cardoso, José Maria Pedrosa (2006), O Canto da Paixão nos séculos XVI e XVII: A Singularidade Portuguesa. Coimbra.

\footnotetext{
84 J. M. P. Cardoso 2006.
} 
Duarte, Sónia Maria da Silva (2011), O contributo da iconografia musical na pintura quinhentista portuguesa, luso-flamenga e flamenga em Portugal, para o reconhecimento das práticas musicais da época: fontes e modelos utilizados nas oficinas de pintura, Mestrado em Ciências Musicais, Faculdade de Ciências Sociais e Humanas. Lisboa.

Fabiani, Enzo (1993), "Cuadros, partituras e instrumentos. Música angelica», revista Amadeus, $\mathrm{n}^{\circ}$ 8, 1993, pp. 47-49.

Gomes, Bernardo Azevedo e Borges, Maria José (1987), «As representações musicais nos códices da Leitura Nova: elementos para o estudo da prática musical e seu contexto ideológico na Corte portuguesa de Quinhentos", VEncontro Nacional de Musicologia, Actas. Lisboa.

Guedes, Natália Correia (1994) (coord.), Encontro de culturas: oito séculos de missionação portuguesa, Mosteiro de S. Vicente de Fora. Lisboa.

Henrique, Luís (1988), Instrumentos Musicais. Lisboa.

Latino, Maria Adriana (1987), «A representação de instrumentos musicais em alguns Presépios portugueses do século xvIII", Boletim da Associação Portuguesa de Educação Musical, $\mathrm{n}^{\circ}$ 52, pp. 62-65.

Meco, José (1989), O Azulejo em Portugal. Lisboa.

Monteiro, Maria do Amparo (1992), A Iconografia musical na Cidade de Coimbra, Mestrado em Ciências Musicais, Faculdade de Letras da Universidade de Coimbra.

Nery, Rui Vieira (1991), The Music Manuscripts in ther Library of King D. João IV of Portugal (1604-1650): a study of Iberian Reportoire in the Sixteenth and Seventeenth centuries, 2 vols. Austin.

Oliveira, Ernesto Veiga de (1966), Instrumentos Musicais Populares Portugueses. Lisboa.

Pereira, Sara (2005) O Fado por Stuart Carvalhais, EGEAC/Museu do Fado. Lisboa.

Pereira, Sara (2009), "Ecos do Silêncio: Para um Estudo Iconológico do Fado", in Actas do Encontro Aprendizes de Feiticeiro, ed. Instituto de História da Arte, Universidade de Lisboa.

Ribeiro, Mário de Sampayo (1943), Aspectos musicais da Exposição de Os Primitivos Portugueses (1450-1550), Centro de Estudos de Arte e Museologia do Instituto para a Alta Cultura, Lisboa.

Serrão, Vítor (2001), «Le panneau de Vasco Fernandes, dit Grão Vasco, dans l'église de Santa Maria de Porco (Guarda)", Revue de l'Art, Paris, 2001, n 4, pp. 57-70.

Serrão, Vítor(2008), O Fresco Maneirista no Paço de Vila Viçosa, Parnaso dos Duques de Bragança. Lisboa.

Silva, Jorge Henrique Pais da (coord.) (1972), Retábulo de Santa Auta. Estudo de Investigação, Centro de Estudos de Arte e Museologia do Instituto para a Alta Cultura. Lisboa.

Teixeira, José (1983), O Paço Ducal de Vila Viçosa. Lisboa.

Trindade, Maria Helena Ferraz (coord.) (1999), Arte e Música. Iconografia Musical na Pintura do Século $x V$ ao Século $x x$. Lisboa. 

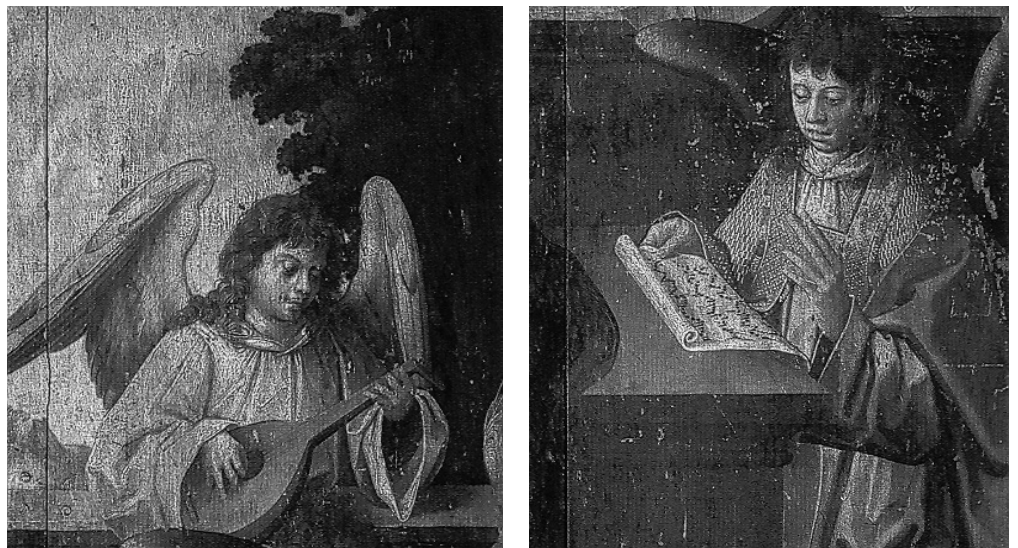

1 e 2 - Anjos com instrumento e pauta musical, pormenores de $A$ Virgem, o Menino e Anjos de Vasco Fernandes na igreja de Aldeia Viçosa (Guarda), c. 1530.

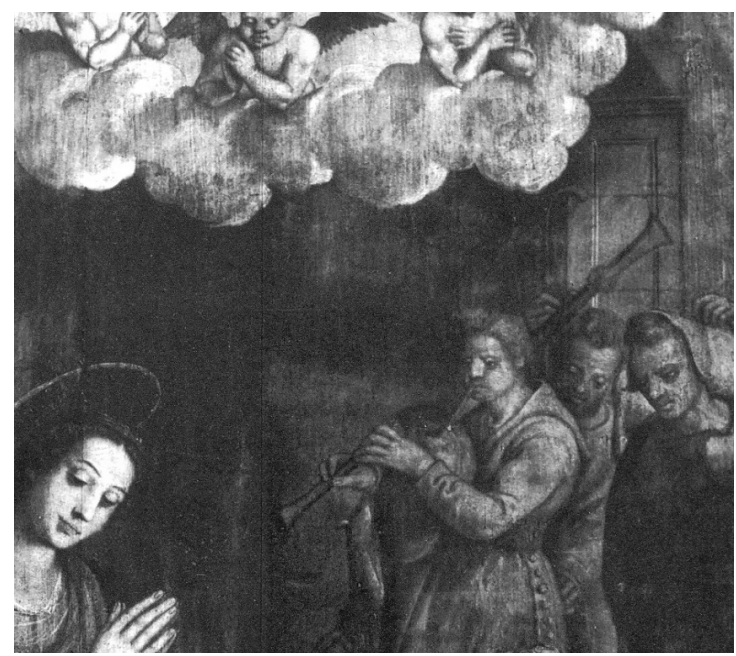

3 - Pastor com gaita de foles, pormenor da Adoração dos Pastores de Diogo Teixeira e António da Costa na igreja da Misericórdia de Alcochete, 1586-1588. 


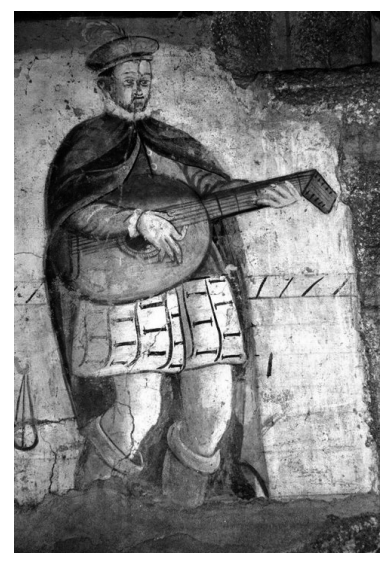

4 - Ingénua representação de jogral num fresco anónimo

do fim do século xvı na igreja de Veigas (Bragança).

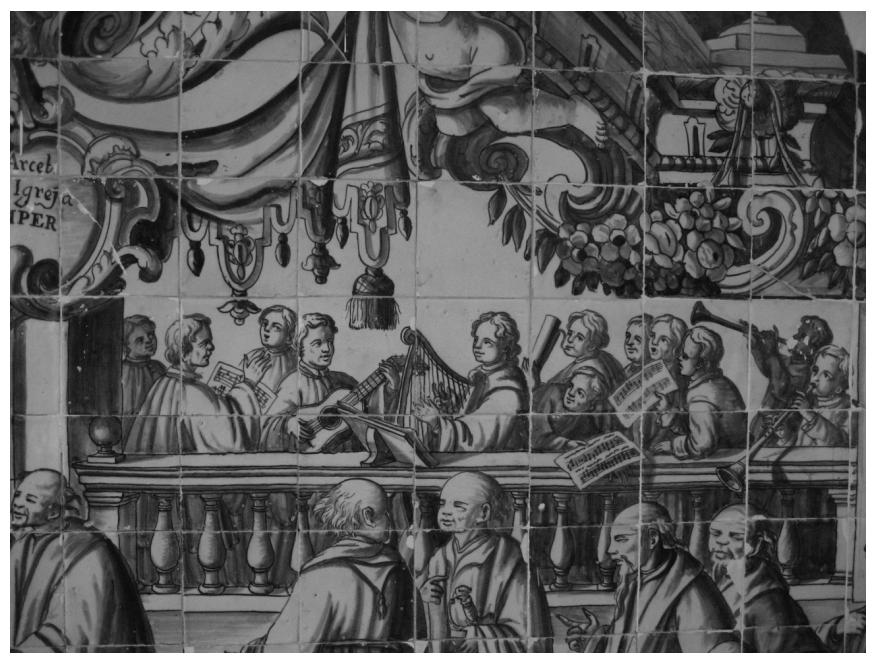

5 - Pormenor dos azulejos com a Vida de D. Frei Aleixo de Meneses no claustro do Convento de Nossa Senhora da Graça de Torres Vedras, pelo Mestrre P.M.P., c. 1720. 


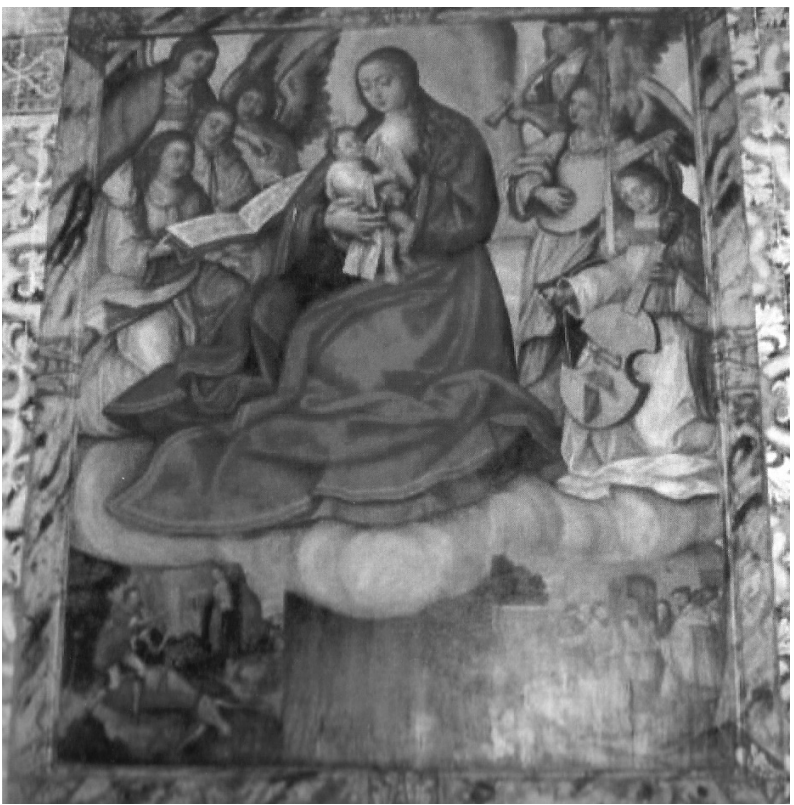

6 - Pormenor do Milagre de Nossa Senhora de Brotas, pintura renascentista de oficina eborense de meado do século xvi, com instrumentos e temas musicais. Mora, Santuário de Nossa Senhora de Brotas.

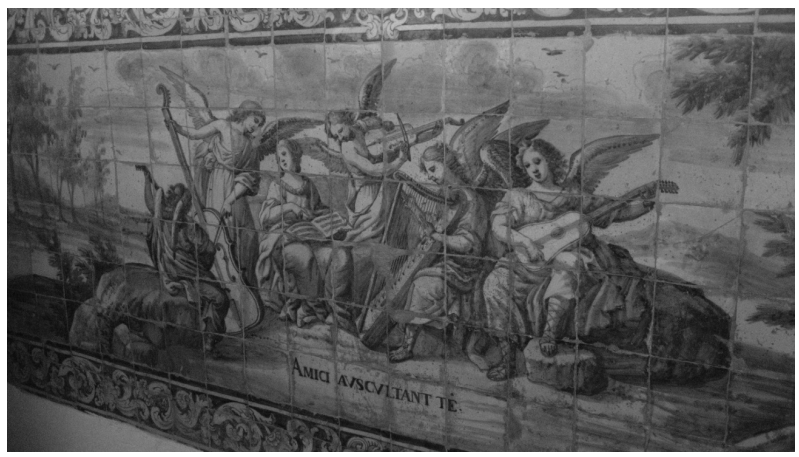

7 - Azulejo com passo do Cântico dos Cânticos, por António de Oliveira Bernardes, no antigo Convento de São Paulo da Serra d'Ossa, no Redondo, cerca de 1710. 


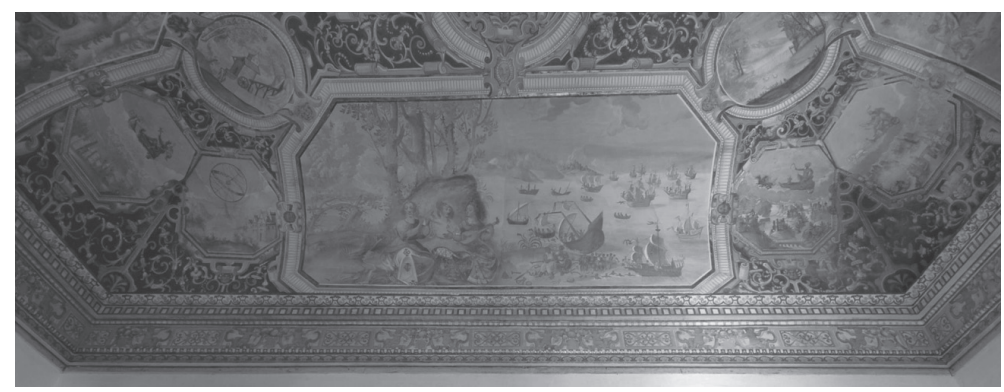

8 - Pormenor de um dos tectos da Sala de Música do Duque de Bragança D. João II

(futuro D. João IV) no Paço Ducal de Vila Viçosa, autor desconhecido, c. 1635.

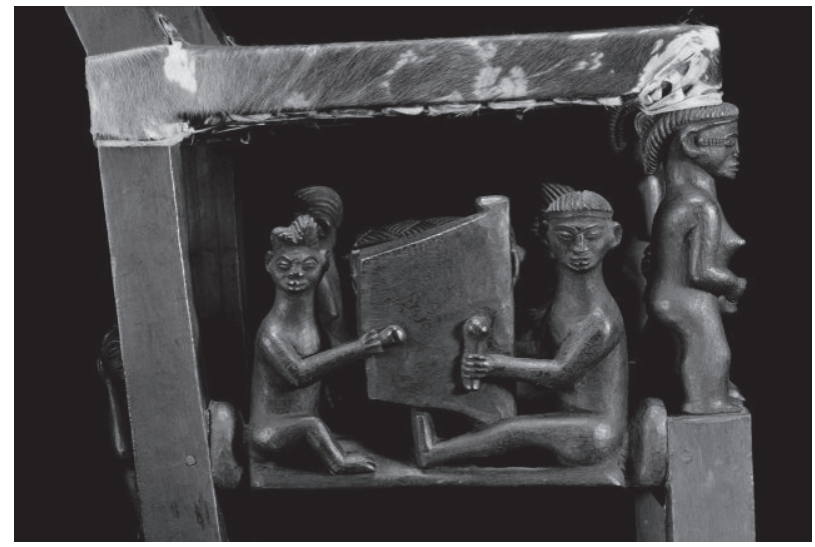

9 - Cadeira de soba: «lateralmente, dois músicos sentados tocam um grande tambor de fenda trapezoidal (cinguvu) com baquetas" proveniente dos Missionários do Espírito Santo, Coimbra, ANT.D.84.1.129. 
(Página deixada propositadamente em branco) 
Rosa Teresa Paião Picado

Conservatório de Música Calouste Gulbenkian de Braga

\section{A MÚSICA NAS OBRAS MÉTRICAS DE \\ D. FRANCISCO MANUEL DE MELLO}

\section{Introdução}

A Academia dos Generosos era uma reunião dos aristocratas que se dedicavam à cultura. Havia saraus, sob a presidência de um dos fidalgos e faziam-se várias publicações, entre as quais estão as Obras Métricas de D. Francisco Manuel de Mello, que presidiu várias vezes à Academia, referindo nos seus textos os serões em que havia música e se declamava poesia diante de uma assistência convidada.

Na Sylva X (pg. 164 da Viola de Thalia), D. Francisco convida um amigo, Dom Ruy de Ruiz, para comparecer na sessão da Academia, que começava às seis da tarde, trazendo os seus músicos:

\section{«[...] Traga Vossa Mercé por seus padrinhos}

aquelles quatro anginhos

Brito, Lima Morais, Manoel Carvalho:

que a todos hei de dar muito trabalho,

segundo os versos cá, vão trabalhozos.

e os moços são para os cantar golozos. [...]»

Devia ter lugar um desafio entre músicos e poetas:

«[...] que neste dia

a Muzica se mate c'o a Poësia. [...]» 
Este desafio seria em público e D. Francisco deseja que haja uma grande audiência:

«[...]Porem se os acha poucos: ou querendo trazer de mais; de mais pode ir trazendo o nosso Dom Fulano, com seu irmaõ Sicrano. por ser já cousa achada de Fulano, e Sicrano, a camarada.
Traga tambem aquelle seu cunhado, taõ bem perdido, como mal achado; e quantos mais senhores nestas noutes quietas, folgaõ de ouuir o demos dos Poëtas, profiar cós diabos dos Cantores. [...]»

Numa outra ocasião, referida como 4 de Maio, o autor escreve o Romance XXVII para a Introduçã̃ festiua de hũa Academia de Musicos, e Poetas (Mello 1665, A Viola De Thalia).

O público devia acomodar-se:

"[...] faltalhe a alguem tamburete esses rapazes que fazem? por esta duns velhaquetes! Ah senhor Antaõ temudo por sua vida que se chegue dè lugar, Senhor Trinchante, componhase, Senhor Mestre Meu Padre Antonio da Silva ora asentese, ora asente. [...]»

Os músicos iriam apresentar-se cantando ou tocando viola de arco:

«[...] qù he da viola de arco vaõ por ella. [...]

[...] Ala aguçar as memorias alto escumar os falsetes;[...]

[...]Cantasse hum Tom, taõ suave, que ninguem mais delle esperte; [...]»

$\mathrm{O}$ autor nomeia os poetas que iriam ter intervenções durante o serão e também a altura em que deverá aparecer a música: 
«[...] que Dom Francisco comece. [...]

[...] Logo Antaõ que Santo Antaõ, jura que tem medo delle; por medo de Santo Antaõ: quando este Antaõ lhe a parece, Lea hum papel que em ò ouuindo, logo o Auditais arrebente; ou pelo menos estalle; quando muito se aquiete. Logo Musicas; e logo o Virgilio do Oriente: [...]

[...] Siga o Correa famoso; que por Correo môr, pede, Apolo para que traga; os versos que o mundo alegrem. Và tras delle quem diante, pode îr, de todos aquelles, que das bicas de aganipe; as discretas aguas bebem, Fernaõ por quem dis Fernando: (como Autores nos referem) quando algũa troua lhe ouue, bofa boa: e isto por este. Logo o senhor Dom Francisco de Mello, agora nos melle, cùm soneto enuergonhado, que enuergonhe ao Rey Ioaõ prestes. O Carualho, que de louro, cedo espero que se enxerte com doces sombras de graça este senado refresque: De hum Poeta algarauio, trago a toardas solemnes, que he Bello, e bello poeta há de ser forcozamente; [...] [...] Porem passemos auante, que eu certo sou bom pobrete, e com hum sò victor nauarro me dou por pago, e contente. [...]»

Nesta obra têm lugar os mais diversos assuntos e, é claro, também a sátira. Na Tabla de los Desconciertos. Satira LXVI (pág. 256 de A Tiorba de Polimnia), o poeta brinca com as várias profissões, entre as quais também está o Músico, sobre o mote:

«Picaros ay que tienen ventura, Picaros ay que no tiene[n] ninguna.

(Del Ladron. Del Letrado. Del Soldado. Del Galon. Del Medico. Del Poëta. Del Musico. Del Caçador. Del Mentiroso. Del Loco. Del Presumido. Del Viejo. Del Corredor. Del Porfiado. Del Thaur.) 


\title{
Del Musico.
}

Que Micer don Facistol

Com sus tufos de viznaga,

por mucha sombra que faga,

diga siempre que fa sol,

que no sepa de Bemol,

si es clave, si es sino, ó que,

$\mathrm{y}$ aun por falsas que haga al re,

queda cantor de natura,

Picaros ay que tienen ventura.
Mas que un tal Cimicorcheo

grogee como chicharra,

sin poder hechar la garra

a sotana, ni a manteo;

que no le ayude el meneo

del compaz, no de la mano,

que à dado a tanto Cristiano

tan lindissima fortuna,

Picaros ay que no tienen ninguna.»

Também o pagamento aos clérigos músicos - que nem sempre devia ser atempado e suficiente - é abordado nesta obra:

\section{«Mandandose hum Regalo a certo Religioso Musico» Epigrama LXXI}

(Mello, 1666 A Viola de Thalia: 235)

\author{
Toda a vida ouui dizer \\ que donde o Clerigo canta, \\ da hy janta, quando janta; \\ sey que o Frade ò mesmo quer. \\ Vos que tanto trabalhastes? \\ razaõ será que entre tanto, \\ poes que naõ jantais do canto, \\ almoceis do que cantastes.»
}

Da familiaridade com que se refere à música, pode deduzir-se que o autor conhecia bem o vocabulário usado na sua época para tratar este assunto. 


\section{Obras Métricas}

Este livro, publicado em 1665 pela Academia dos Generosos de Lisboa e dedicado ao Infante D. Pedro, foi impresso em Leon de Francia por Horacio Boesset e George Remeus e contém textos em português e em espanhol. Obteve a primeira licença de impressão em 30 de abril de 1665, a segunda, em 2 de maio do mesmo ano e finalmente foi impresso em 4 de maio de 1665.

D. Francisco Manuel de Mello era um Académico deste "clube" de aristocratas $^{85}$ e há nesta obra vários textos que usou para abrir as sessões da Academia, enquanto presidente.

\subsection{Conteúdo de Obras Métricas}

Obras Métricas é um volume dividido em várias partes:

Las Tres Musas

El Harpa de Melpomene, primeira Musa do Melodino. Sonetos.

La citara de Erato, segunda musa do Melodino. Romances.

La Tiorba de Polymnia, terceira musa do Melodino. Metros.

El Pantheon

Pantheon a la Immortalidad del Nombre: Itade. Al Conde Camarero Mayor. Poëma Tragico. Diuidido en dos Soledades.

Las Musas Portuguesas

A Tuba de Calíope, Quarta Musa do Melodino. Rimas.

A Çanfonha de Uterpe, Quinta Musa do Melodino. Eglogas e epistolas.

A Viola de Thalia, sexta Musa do Melodino. Obras.

El Tercer Coro de las Musas

La Lira de Clio, sétima Musa do Melodino. Epigramas.

La Avena de Tersicore, octava Musa del Melodino. Tonos e Romances. La fistula de Urania, nouena Musa del Melodino. Asunto.

\footnotetext{
85 Generosos queria dizer nobres.
} 


\subsection{As Musas e os Instrumentos}

\begin{tabular}{llll} 
Musa & Arte & Instrumento & Texтo \\
\hline Melpómene & Tragédia & Harpa & Sonetos \\
Érato & Poesia Amorosa & Cítara & Romances \\
Polímnia & Hinos religiosos & Tiorba & Metros \\
Euterpe & Poesia Lírica & Çanfonha & Éclogas e Epístolas \\
Tália & Comédia & Viola & Obras \\
Clio & História & Lira & Epigramas \\
Calíope & Poesia Épica & Tuba & Rimas \\
Terpsicore & Dança & Avena & Tonos e Romances \\
Urania & Astronomia & Fistula & Asunto
\end{tabular}

A cada uma das nove musas corresponde um instrumento: A Melpómene, musa da Tragédia, é atribuída a Harpa e neste capítulo o autor apresenta Sonetos; a Érato, musa da Poesia Amorosa, cabe a Cítara, para os Romances; a Tiorba pertence a Polímnia, a musa das canções dedicadas aos deuses, nos textos chamados Metros; Euterpe, musa da Poesia Lírica, toca Çanfonha e preside ao capítulo das Éclogas e Epistolas; a Viola é o instrumento de Tália, musa da Comédia, que introduz as Obras; Clio, musa da História, intitula o capítulo dos Epigramas e apresenta-se com a Lira; a Poesia Épica, inspirada por Calíope, tem como instrumento a Tuba, num conjunto de textos intitulados Rimas; os Tonos e Romances são regidos por Terpsícore, a Musa da Dança, que usa uma Avena; finalmente a musa da Astronomia, Urania, que traz a Fistula e inicia o capítulo que contém Asunto.

Além dos títulos que encimam as diferentes partes, esta relação entre as Musas e os instrumentos é referida por D. Francisco Manuel na pág. 265 da Viola de Thalia:

«Panegírico por Introduçaõ, ao Real certamen que na Academia dos Generosos de Lisboa. Offerece o Conde da Torre, de aluiçaras a Portugal, o dia que se celebra o ditoso nascimento da Serenissima Senhora Infanta. D. Caterina, agora Raynha de Inglaterra que Orou D. Francisco Manuel, em sua Terceira Prezidencia Academica. 
[...] Naõ vedes, naõ estais ouuindo que nesses armoniosos Coros onde se deue[m] celebrar vossas contendas, donde se haõ de cantar vossas Victorias està soando aquelle milagroso discante de nossas Musas: Escuytai ouui, como tocaõ como cantaõ as perfeiçoẽs de nosso Asunto Melpomene, na Arpa, Erato na Citara. Polimnia, na Tiorba: Caliope, na Tuba: Euterpe, na Çamfonha, Talîa na Viola. Clio na Lira, Tersicore na Auena. Urania na Fistula. [...]»

Introduzindo o terceiro Coro das Musas aparece uma Epistola alos letores [...], em que um outro autor, que se identifica como El Candido. Academico Generoso, elogia o modo como o Poeta invocou estas deidades e as relacionou com os capítulos, ao contrário de outros Poetas, que tomam apenas o nome das Musas, sem se preocuparem com o rigor da atribuição dos géneros a cada uma delas, como se usava na Antiguidade:

«Epistola alos letores por un aficionado del Autor, y del Estudio Poetico.

[...] Pero es tiempo de darte la ultima satisfaçion que podrás pedirme: entendiendo que no se há puesto entera correspondencia entre los humores de las Musas y de las Obras: por que segun consta de la antiguedad, y se conoce del Mantuano, Cadaqual de las musas, tiene su ocupacion determinada segun aquel tan sabido Lugar.

\footnotetext{
Clio gesta canens transactis tempora reddit

Melpomene, tragico proclamat mostu boatu

Comica lasciuo gaudet sermone Thalia

Dulciloquis Calamos Euterpe flutibus vrget Terpsicore affectus Citharis mouet imperat auget.
} Plectra gerens Erato saltapede carmina vultu. Carmina Calliope libris heroïca mandat. Uranie Cœli metus scrutatur \& astra Signa cuncta manu, loquitur. Polyhymma gestu.

Es assy; más verás que esta observacion no se halla en ninguno de los Poetas, Vulgares por que como solo se han tomado sus nombres de las 
Musas, en significacion lata, de uarios generos de armonia, no se estrecharon a rigurosa sentencia del proprio significado en el nombre de cada Musa. Porque sy debaxo de esse riguroso compáz se obligassen los Poetas a inuocar sus Musas, bien le conoce el inconveniente y desproporcion com que las han solicitado en sus inspiraciones. [...] Vemos todavia que estos doctissimos hombres se han dado por satisfechos llamando algunas de las Musas sin la prolixa especulacion de su conveniencia, no porque laignorassen, sino porque como este nombre Musa en la rais Griega, quiere deçir toda ó qualquier honesta ybuena disciplina; esta significaçion basta para que cada Musa pueda ser Inuocada decada Poeta y selepuedan, sin inconpetençia adiudicar los Metros, y los Asuntos, conforme em los tres Coros de las tres partes, o tres libros de nuestro Poeta. [...]”

Só Calíope, Terpsícore e Urania têm instrumentos de sopro (os instrumentos altos), decerto porque as suas artes exigem som forte - a Poesia Épica, que narra os grandes feitos, terá um instrumento sonoroso, como a tuba; a Dança precisa de um instrumento portátil e que se faça ouvir, tanto em casa como ao ar livre, a avena; a Astronomia usa o som penetrante da fístula, talvez em relação com a música das esferas. Todas as outras musas usam instrumentos de cordas, cujo caráter se associa às respetivas áreas de inspiração, sendo de destacar a Viola, que está relacionada com a Comédia, mas também com o canto e a música que eram habituais nas festas de Baco, as Dionisíacas campestres. Esta ligação aparece também no texto de D. Francisco, na farça $O$ Fidalgo Aprendiz, quando Dona Brites interroga Dom Gil Cogominho sobre as suas habilidades e, depois de saber que entre elas estão tanger e cantar, lhe pede:

«[...] Br. Entoay por meu prazer qualquer cousa.

G. Sem Guitarra?

Br. Eylla tomay.
Dalhe hũa viola, tange como que quer cantar.

G. Pois que naõ posso al fazer,

Br. Ay que canta, e naõ escarra!

G. Ora eylo vay. 
Canta Dom Gil ò melhor que pode ò que se segue cantando.

G. Passeauasse Siluana

por hum corredor hum dia [...]»

(Mello 1665, A Viola de Thalia: 247)

Daqui se infere que no séc. xvir era precisa uma guitarra para acompanhar o canto e que este instrumento seria usado tanto pelos nobres - Dom Gil está a aprender a ser fidalgo -, como pelas classes mais baixas - é o instrumento que ele sabe tanger e que imediatamente usa, quando instado a cantar; era também usada no teatro, fazendo a transição entre as cenas, como aparece ainda no Fidalgo Aprendiz:

"Entraõ se ambos, tocaõ se as violas e se a caba a Primeira Iornada" (Mello 1665, A Viola de Thalia: 245)

É de notar ainda a terminologia usada no texto: obviamente as designações guitarra e viola referem-se ao mesmo instrumento; embora viola fosse o termo mais comum, também algumas vezes aparecia guitarra, o que, aliás, consta também no manuscrito Cifras de Viola por Vários Autores, parte do acervo da Biblioteca Geral da Universidade de Coimbra - f. 92r: Alemanda do laude posta na guitarra; f. 99v: Acordio de guitarra a $1^{a}$ com a $4^{\mathrm{a}}$; f. 103r: Como se tempera a guitarra; esta alternância das designações era muito natural, atendendo a que havia pouco tempo que tinha terminado a dinastia filipina, em que os artistas e os músicos se exprimiam tanto em português como em espanhol e as duas línguas ocasionalmente se fundiriam, como acontece também nesta publicação da Academia dos Generosos.

Não deixa de ser curiosa a associação de uma entidade da Mitologia Clássica, a Musa, com um instrumento barroco - lembrando o costume de vestir as personagens mitológicas da ópera com as roupas que se usavam no tempo dos autores e fazendo-as comportar-se à maneira das pessoas desta mesma época.

Também Polímnia está nesta situação - usa a Tiorba, que, no texto, é associada às lágrimas: 
"Idylio Lyrico Historial. Desengaño. Sylva. XIX.

Al lagrimoso son de las querellas,

Que en vez de cuerdas, lastimas tocando,

Forman al ayre consonancia triste, [...]

[...] Donde el arroyo ser tiorba quiso, [...]»

(Mello 1665, A Viola de Thalia: 212)

Opondo-se à tristeza, a alegria: este é um dos instrumentos que o Mestre de Dança pede para acompanhar a lição (em primeiro lugar estão os instrumentos de cordas dedilhadas - o alaúde, a viola ou a harpa - e só depois a percussão - os cascavéis).

«[...]Mestre. Há em casa algum laude?

Alfonso. Naõ há mais que hũ birimbao.

M. Violas?

A. Sim achareis

na botica.

M. Arpa?

A. De couro.

M. Nem hum festro?

A. Hum festro agouro.

M. Nem sequer dous cascaveis?

Gil. Eu andei co à alma nos dentes

estoutros dias passados

por que diz, que os namorados

nunca podem ser contentes.

Despedi toda a capella

que em desafinando estroje;

de sorte que quanto he oje

fareis som numa panella. [...]»

(Mello 1665, A Viola de Thalia: 242)

A Tiorba e o Alaúde eram instrumentos semelhantes e tinham a mesma função: acompanhar a voz ou a dança, ou então tocar a solo, nas mais diversas situações. Mersenne, contemporâneo do autor, descreve-os assim: 
"[...] le Luth augmenté d'um nouveau manche [...] qui sert pour donner une plus grande estenduë aux 4. dernieres chordes [...]. L'on apelle ce Luth à deux manches Tuorbe, lequel n'a souvent q'une seule chorde à chaque rang, encore que celuy-cy ait tous ses rangs doubles, excepté celuy de la chanterelle qui est simple. [...]»(M. Mersenne 1963: 45).

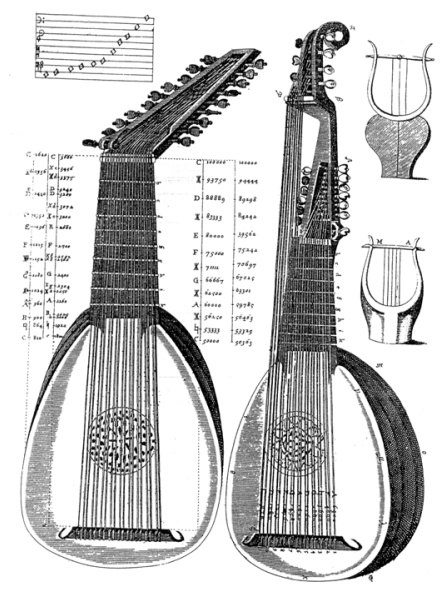

Por seu lado, a Lira, atribuída a Clio, aparece no texto como o instrumento de Apolo, simbolizando o talento para a poesia:

"[...] Que tens câ que pedir Lyras a Apolo [...]»

Noutro poema, D. Jorge da Camara é elogiado como se tivesse recebido a lira diretamente daquele deus:

«[...] a este culto Reytor das Musas noue

o sempre a gudo Iorge

da Camara de Apollo gentil home[m]

Mestre, Cantor, Secretario

Deulhe de sua maõ propria

Apollo a temperar a lira douta

Depois detemperada tocou nella

e Apollo 
ou de corrido

ou de obrigado

ou jà de tudo

por escuzar se note a diferença

de aquellas maõs

a estoutras

deixou the a Lira

naõ hejà de Apollo

tú cuidas que elle tange

As cadencias observa

ouue

e verás ouuindo

quantos melhores toñs na Lira saõ [...]»

Aqui a ambiguidade é maior. A Lira de Apolo seria com certeza o instrumento grego; mas, nesta época, também se chamava Lira um outro instrumento, que se tocava com arco, e se usava para acompanhar a voz; Mersenne apresenta-a assim:

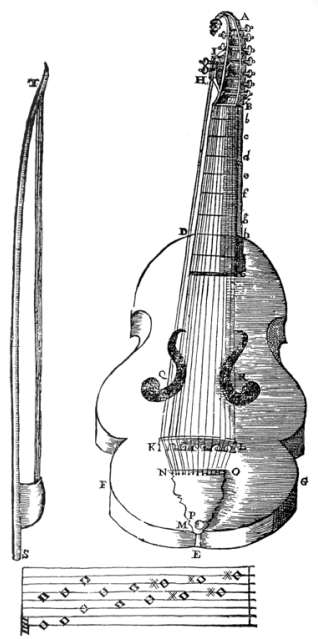

«La figure de la Lyre est fort peu differente de celle de la Viole [...] son manche, \& la touche du manche est beaucoup plus large, d'autant qu'elle est couverte de quinze chordes, dont les 6 premieres ne font 
que trois rangs, \& si l'on veut doubler chaque rang, comme l'on fait sur le Luth, l'on aura 22 chordes. L'on met les deux plus grosses hors du manche [...] ; \& le petit manche [...] est adiousté pour les bandes. Il nést pas besoin d'auertir que l'on peu adiouter un second manche semblable au second des Tuorbes, pour y mettre tant de basses que l'on voudra [...] Or le son de la Lyre est fort languissant \& propre pour exciter à la devotion, \& pour faire rentrer l'esprit dans soy-mesme; l'on en use pour accompagner la voix et les recits. [...] il n'y a peut estre nul instrument qui represente si bien la Musique d'Orphée \& de l'antiquité [...]» (M. Mersenne 1963: 204).

A Cítara, instrumento de Erato, é também referida nos Tercetos do capítulo A Tiorba de Polimnia (Mello 1665: 171)

«[...] Quisiera ver la cythara templada

A su voz, y sus cuerdas tan subidas,

Que os cantasse una Iacara pintada.

Pero en vano, que a cuerdas tan perdidas,

Que en clausuras sirvieron sufficientes

Al canto de la emienda de otras vidas

No se entonan los metros differentes; [...]»

O instrumento servia para acompanhar o canto e a dança - note-se que o autor deseja poder cantar uma Iacara pintada. A Iacara, segundo a definição de Raphael Bluteau,

"he um tom em quartetos, que de ordinario se canta nas Loas, ou cantigas compridas, em que se narraõ sucessoss» (R. Bluteau 1712-1728: s. u. iacara).

Teria, assim, alguma relação com os romances desta época, que, certamente, teriam alguma parte instrumental; pintada poderia ser uma referência aos negros, que viviam em Portugal, cuja linguagem era muitas vezes retratada nestas obras. 


\section{Tonos}

No Capítulo La Avena de Tersicore, D. Francisco Manuel escreve Tonos e Romances. Em todos os Tonos é indicado o compositor da música, bem como a intenção do texto.

\section{«La Avena de Tersicore, octava Musa del Melodino, Tonos y Romances.}

Escriviose de Buenas Pascoas e la Magd de la Reyna de Inglaterra; para que se cantasse en su Camara, y fué la musica del Maestro Miguel de Herrera. Tono I.

Para cantarse a la mesma Serenissima Reyna, despues de um saráo real, en que dançaron los Reyes; puesto en musica, del proprio Maestro. Tono II.

El Retrato de una Damas hecho de los Naypes; com musica del P.M.F. Felipe de la M. de D. Tono III.

La linda Francesa: puesto en Musica por el P.M.F. Pelipe de la M. de D. Tono IV

Lutos e Lagrimas de la divina Licis: puesto en Musica por el P.M.F. Luis de Cristo. Tono V.

Lutos hermosos: puesto en Musica por el proprio Maestro. Tono VI.

Desengaños ultimos amorosos: puesto en Musica por el Maestro Gaspar de los Reyos. Tono VII. Despedida sin esperança. Puesto en Musica por el Maestro Antonio Marques. Tono VIII.

Años y Amores vida. puesto en Musica por el P.M.F. Felipe de la M. de D. Tono IX.

La Travessura atapada: puesto en Musica por el P.M.F. Felipe de la M. de D. Tono IX.

Saüdades desesperadas. Puesto en musica, por el Maestro Antonio Marques. Tono X.

Iustificacion de temores. Puesto in musica por el P.M.F. luis de Cristo. Tono XI.

La terrible Hermosura. Puesto in musica por el mesmo Maestro. Tono XII.

Ruyna argumentosa. Puesto en musica por el P.M.F. Pelipe de la M. de D. Tono XIII.

Corte en la Aldea Enceladilla real alas Damas de Palacio. Puesta en musica por el P.M.F. Felipe de la M. de D. Tono XIV.

La Primavera. Puesto en musica por el Insigne Maestro real. Iuan Suares Rebelo. Tono XV.

Dama de Cabos negros. Puesto en musica por el Maestro Gaspar de los Reyes. Tono XVI.

Novela des dicha da Puesto en musica por el P.M.F. Felipe de la M. de D. Tono XVII.

Dama que se perdió entre la muchedumbre. Puesto en musica del Maestro Gaspar de los Reyes. Tono XVIII.

Belleça no conocida Puesto en musica por el P.M.F. Felipe de la M. de D. Tono XIX

Celebrando la raridad de unos ojos. Puesto en musica por el Maestro Esteval de Faria. Tono XX.

La bella Madrina. Puesto en musica por el Maestro Marcos Suares. Tono XXI.

Haviendo llegado dos Damas a su Porteria para subir a Palacio, se hallava dormido el portero: a quien llamarõ en vano; y por celebrar esta accion, se escrivió este Tono. Puesto en musica por el Maestro Marcos Suarez. Tono XXII. 
Pidieronende las coplas que se siguen para cõtinuar un Tono, que a la primera copla se hairá hecho, el P.M.F. Pelipe de la M. de D. Tono XXIII.

Dama en noche de luminarias. Puesto en musica por el Maestro Felipe de la Cruz. Tono XXIV.

Iacarilla de devocion, en la fiesta de San Francisco: puesta en musica por el Maestro Marcos Suares. Tono XXV.

En Fiesta de Natividad, de la Virgen, compuesto por el P.M.F. Antonio de I. Tono XXVI.»

\subsection{Ocasião para que foram escritos}

Os Tonos versam temas muito diferentes. Em alguns casos, é indicada a ocasião para que foram escritos; em dois deles, a intenção é profana: para desejar Boa Páscoa a D. Catarina, Rainha de Inglaterra, ou para lhe cantar depois de uma festa; outros dois servem para festejar acontecimentos religiosos: para a festa de S. Francisco, ou do Nascimento da Virgem, estando assim mais próximos da forma Vilancico. Todos os outros referem temas caraterísticos da lírica da época, sem nenhuma outra indicação: o amor, a despedida, a saudade, etc. Esta temática confirma a distinção que no séc. XviI se fazia entre Tonos ou Tonos Humanos e Vilancicos, em que estes últimos passaram a representar somente textos religiosos, enquanto aos Tonos cabia o texto profano (R. Bessa 2001: 24).

\subsection{Estrutura}

\begin{tabular}{|c|c|c|c|c|}
\hline Tono & Ocasião / Título & $\mathbf{N}^{\circ}$ Estrofes & Estribilho & Coplas \\
\hline I. & $\begin{array}{l}\text { Páscoa - para a Rainha } \\
\text { de Inglaterra }\end{array}$ & $8-4$ versos & & \\
\hline II. & $\begin{array}{l}\text { Depois de um Sarau } \\
\text { Real - para a Rainha de } \\
\text { Inglaterra }\end{array}$ & 7- 4 versos & $5-2$ versos & \\
\hline III. & Retrato de uma dama & $7-4$ versos & $1-10$ versos & \\
\hline IV. & La linda Francesa & $6-4$ versos & $1-6$ versos & \\
\hline V. & $\begin{array}{l}\text { Lutos e lágrimas de la } \\
\text { divina Licis }\end{array}$ & $8-4$ versos & $1-3$ versos & \\
\hline VI. & Lutos hermosos & $8-4$ versos & & \\
\hline
\end{tabular}




\begin{tabular}{|c|c|c|c|c|}
\hline Tono & Ocasião / Título & $\mathbf{N}^{\circ}$ Estrofes & EstribiLHo & Coplas \\
\hline VII. & $\begin{array}{l}\text { Desengaños ultimos } \\
\text { amorosos }\end{array}$ & $6-4$ versos & $1-3$ versos & \\
\hline VIII. & Despedida sin esperança & $6-4$ versos & $1-4$ versos & \\
\hline IX. & Años e Amores vida & $6-4$ versos & 1- 7 versos & \\
\hline IX. & La travessura Atapada & $8-4$ versos & & $2-7$ versos \\
\hline $\mathrm{X}$. & Saüdades desesperadas & $9-4$ versos & $1-6$ versos & \\
\hline XI. & Iustificacion de temores & $8-4$ versos & $\begin{array}{l}1-4 \text { versos } \\
+4 \text { yó }\end{array}$ & \\
\hline XII. & La terrible hermosura & $6-4$ versos & $\begin{array}{l}3 \text { estrofes:1. } \\
2 \text { versos; } 2 . \\
6 \text { versos; } 3 . \\
2 \text { versos }\end{array}$ & \\
\hline XIII. & Ruyna argumentosa & $19-4$ versos & 1 - 2 versos & \\
\hline XIV. & $\begin{array}{l}\text { Corte en la Aldea Encela- } \\
\text { dilla real alas Damas de } \\
\text { Palacio }\end{array}$ & $\begin{array}{l}9 \text { estrofes: } 1-5 \\
\text { versos; } 2 \text { a } 8 .-2 \\
\text { versos; } 9 .-3 \\
\text { versos }\end{array}$ & & $\begin{array}{l}7 \text { Coplas: } 1 \text { para } \\
\text { cada Dama. } \\
\text { I a VI: } 1 .-4 \text { ver- } \\
\text { sos; } 2 . \text { - } 3 \text { versos; } \\
\text { VII: } 4 \text { v.; } 3 \text { v.; } 4 \text { v.; } \\
3 \text { v. } \\
\text { Coplas } \\
1.6 \text { versos; } 2.2 \\
\text { versos; } 3.6 \text { versos; } \\
4.5 \text { versos }\end{array}$ \\
\hline
\end{tabular}

23 estrofes: 1 a

6. - 4 versos; 7. - 7

versos; 8 . - 2 ver-

$\begin{array}{ll}\text { XV. La Primavera } 9 .-4 \text { versos; } & \text { sos }-3 \text { versos; } 11\end{array}$

a 13. - 2 versos;

5 estrofes: 1 e 2 -

4 versos; 3 e $4-2$

14 a 17. - 4 versos;

versos; 5.3 versos

18. - 7 versos; 19 a

23. - 4 versos

\begin{tabular}{|c|c|c|c|c|}
\hline XVI. & Dama de Cabos Negros & $9-4$ versos & $1-5$ versos & \\
\hline XVII. & Nouela desdicha & $8-4$ versos & $1-4$ versos & \\
\hline XVIII. & $\begin{array}{l}\text { Dama que se perdió en- } \\
\text { tre la muchedumbre }\end{array}$ & $7-4$ versos & 1 - 4 versos & \\
\hline XIX. & Belleça no conocida & $6-4$ versos & $1-5$ versos & \\
\hline XX. & $\begin{array}{l}\text { Celebrando la raridad de } \\
\text { unos ojos }\end{array}$ & $8-4$ versos & $1-4$ versos & \\
\hline XXI. & La bella Madrina & $7-4$ versos & $\begin{array}{l}\text { 1. } 6 \text { versos; } \\
\text { 2. } 5 \text { versos }\end{array}$ & \\
\hline XXII. & $\begin{array}{l}\text { Duas damas chegaram } \\
\text { e o porteiro estava a } \\
\text { dormir }\end{array}$ & 6- 4 versos & $1-3$ versos & $\begin{array}{l}\text { 1. } 4 \text { versos; } \\
\text { 2. } 6 \text { versos; } \\
\text { 3. = estribilho ( } 3 \\
\text { versos) }\end{array}$ \\
\hline XXIII. & Para continuar um Tono & $8-4$ versos & $1-4$ versos & \\
\hline
\end{tabular}




\begin{tabular}{|c|c|c|c|c|}
\hline Tono & Ocasião / Título & $N^{\circ}$ Estrofes & Estribilho & Coplas \\
\hline XXIV. & $\begin{array}{l}\text { Dama en noche de lumi- } \\
\text { narias }\end{array}$ & 6 - 4 versos & $1-6$ versos & \\
\hline XXV. & $\begin{array}{l}\text { Iacarilla de devocion - } \\
\text { festa de } S \text {. Francisco }\end{array}$ & $14-4$ versos & $1-5$ versos & \\
\hline XXVI. & $\begin{array}{l}\text { Festa do Nascimento da } \\
\text { Virgem }\end{array}$ & $9-4$ versos & & $\begin{array}{l}4 \text { versos } \\
6 \text { versos }\end{array}$ \\
\hline
\end{tabular}

Na sua maioria, os textos compõem-se de estrofes com quatro versos, embora graficamente se encontrem separadas apenas pela deslocação para a esquerda do primeiro verso de cada uma, que também é o único que começa com letra maiúscula. Em vinte e um Tonos há um estribilho, cujo número de versos é variável e apenas em três casos tem mais do que uma estrofe. Em quatro Tonos há Coplas, sem haver Estribilho; no Tono XIV, as Coplas dividem-se em seis textos de várias estrofes, cada uma com seu título celebrando uma Dama, a que se seguem novas Coplas; o Tono XXII apresenta um Estribilho e Coplas, sendo a última estrofe das Coplas igual aos três versos do Estribilho.

\subsection{Rimas}

\begin{tabular}{|c|c|}
\hline Tono & Rima \\
\hline I & 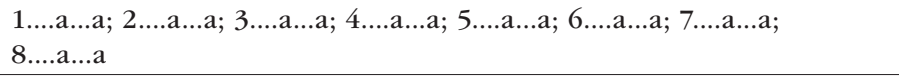 \\
\hline II & $\begin{array}{l}\text { 1...а...a; } 2 \ldots a \ldots a ; 3 \ldots a \ldots a ; 4 \ldots a \ldots a ; 5 \ldots a \ldots a ; 6 \ldots a \ldots a ; 7 \ldots a \ldots a \\
\text { Estribilho: ww/yy/xx xx xx }\end{array}$ \\
\hline III & 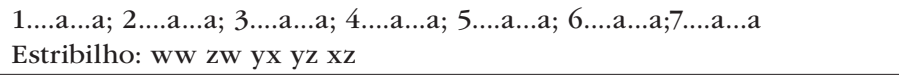 \\
\hline IV & 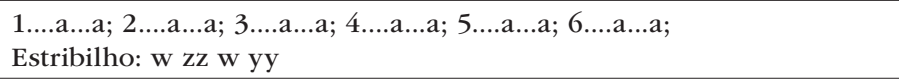 \\
\hline $\mathrm{V}$ & 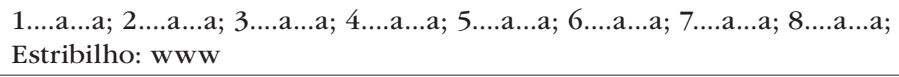 \\
\hline VI & 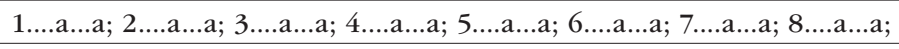 \\
\hline VII & 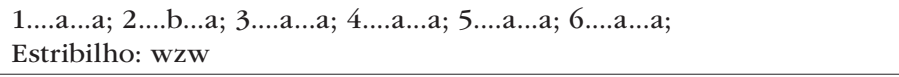 \\
\hline VIII & $\begin{array}{l}\text { 1...а...a; } 2 \ldots \text { a..a; } 3 \ldots a \ldots a ; 4 \ldots . . . a ; 5 \ldots a \ldots a ; 6 \ldots a \ldots a ; \\
\text { Estribilho: wzzz }\end{array}$ \\
\hline IX (1) & 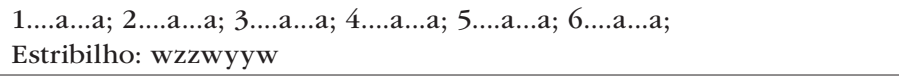 \\
\hline IX (2) & 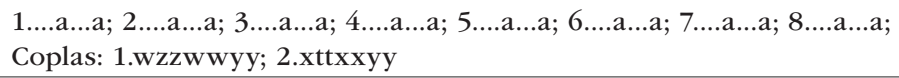 \\
\hline
\end{tabular}




\begin{tabular}{|c|c|}
\hline Tono & RIMA \\
\hline $\mathrm{X}$ & 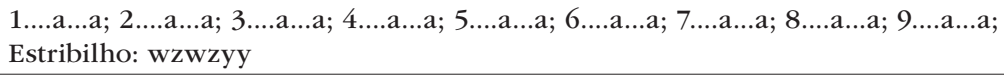 \\
\hline XI & $\begin{array}{l}\text { 1...a..a; } 2 \ldots \text { a...a; } 3 \ldots a \ldots a ; 4 \ldots . . . a ; 5 \ldots a \ldots a ; 6 \ldots a \ldots a ; 7 \ldots a \ldots a ; \\
\text { Estribilho: wwzwzww }\end{array}$ \\
\hline XII & 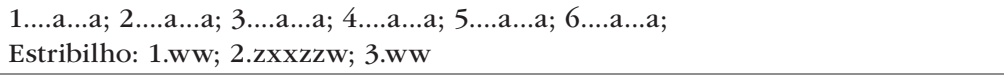 \\
\hline XIII & 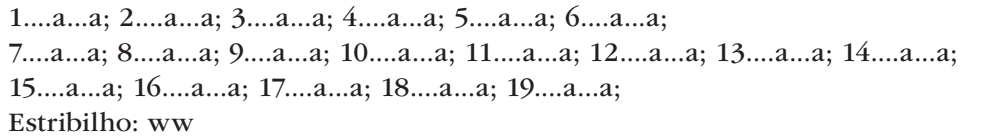 \\
\hline
\end{tabular}

1.aaabbb; 2. cc; 3. dd; 4. ee; 5. ff; 6. gg; 7. hh; 8. ii; 9. jij

Coplas (En celebracion de las Damas que se hallaron em esta jornada com sus proprios nombres)

Sra. D. Antonia da Sylva: $1 \ldots . . . . . k ; 2.1 \mathrm{ml}$

Sra. D. Maria de Lencastre: 1 ....k...k; 2. CDC

XIV Sra. D. Vicencia de Castro: 1 ....k...k;2. opo

Sra. D. Mariana Iosefa de Mendoça: 1 ....k...k; 2 . nqn

Sra. D. Maria de Portugal: $1 \ldots . . . . . k$; 2 . rsr

Sra. D. Elvira de Vilhena: $1 \ldots . . . . . k ; 2$. tut

Sra. D.Francisca de Vilhena: 1....k...k; 2. uvu; 3...xx...x; 4. ABA

Coplas: 1. www; 2. zz, 3. MKKMKz; 4. zzzKK

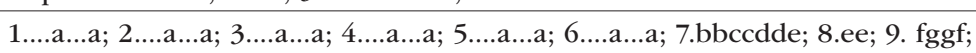

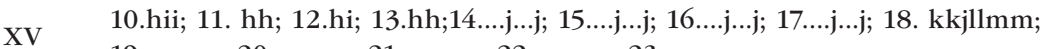

$19 . \ldots . . . n ; 20 \ldots . n . . n ; 21 \ldots . n \ldots n ; 22 \ldots . n . . n ; 23 \ldots . n . . n$

Coplas: 1. AAAB; 2. CDDC; 3. CC; 4. EE; 5. EFF

\begin{tabular}{|c|c|}
\hline XVI & 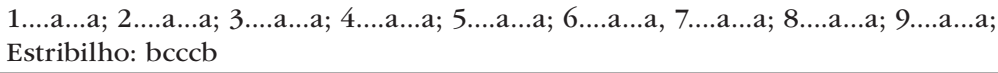 \\
\hline XVII & 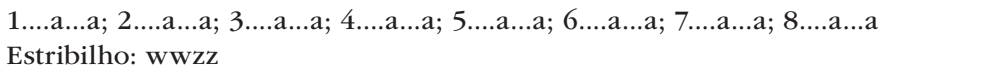 \\
\hline XVIII & 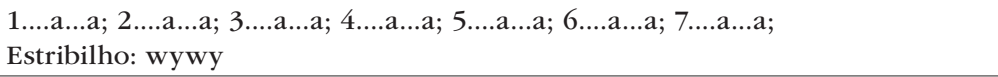 \\
\hline XIX & 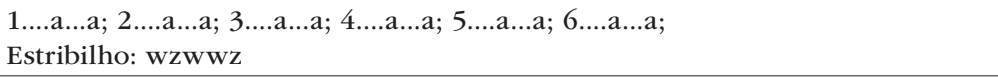 \\
\hline $\mathrm{XX}$ & 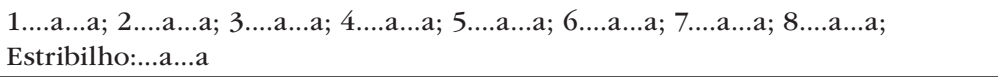 \\
\hline XXI & 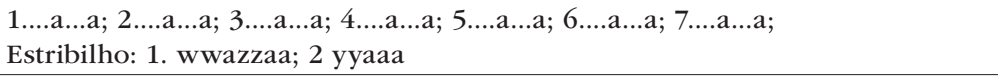 \\
\hline XXII & 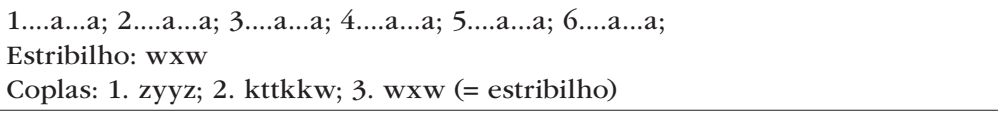 \\
\hline XXIII & 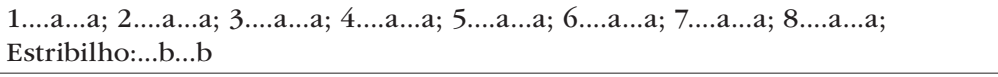 \\
\hline XXIV & 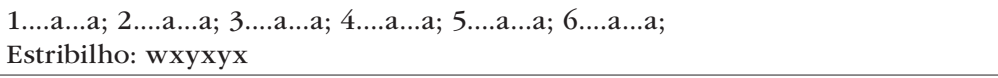 \\
\hline XXV & 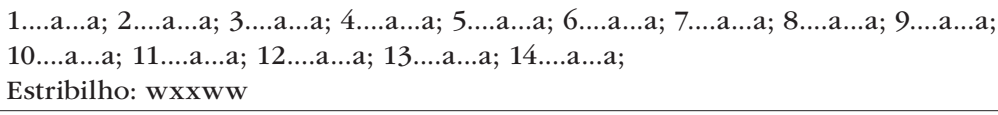 \\
\hline XXVI & 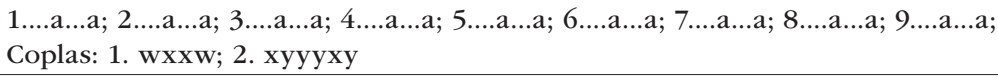 \\
\hline
\end{tabular}


Em quase todos os textos é utilizada a rima assonante (que coincide só nas vogais) no segundo e quarto versos das estrofes; no Estribilho e nas Coplas, o autor usa rima consoante, estabelecendo assim formalmente uma diferença entre o texto das estrofes e o das Coplas, ou do Estribilho, que provavelmente apareceria também na música que se cantava.

\subsection{Métrica}

\begin{tabular}{|c|c|c|c|}
\hline Tonos & Estrofes & Estribilho ( ${ }^{\circ}$ De SílLABAs) & Coplas ( $\mathrm{N}^{\circ}$ De SÍlabas) \\
\hline I & $8 \times 4-7$ sílabas & & \\
\hline II & 7 x 4 -7 sílabas & $\begin{array}{l}8 / 6 / 7 / 7 / 7 / 7 / 4 / 4 / 4 \\
/ 4\end{array}$ & \\
\hline III & 7 x 4 -7 sílabas & $\begin{array}{l}6 / 4 / 6 / 4 / 5 / 6 / 4 / 6 / \\
5 / 5\end{array}$ & \\
\hline IV & $6 \times 4$-7 sílabas & $4 / 7 / 7 / 8 / 8$ & \\
\hline $\mathrm{V}$ & $8 \times 4$-7 sílabas & $6 / 7 / 4$ & \\
\hline VI & $8 \times 4$-7 sílabas & & \\
\hline VII & $6 \times 4$-7 sílabas & $6 / 6 / 6$ & \\
\hline VIII & $7 \times 4$-7 sílabas & $\begin{array}{l}7 / 7 / \underline{1 / 1} \text { - eco da última } \\
\text { sílaba do verso anterior }\end{array}$ & \\
\hline IX [1] & $6 \times 4-7$ sílabas & $7 / 7 / 7 / 7 / 6 / 4 / 6$ & \\
\hline IX [2] & $8 \times 4$-7 sílabas & & $2 \times 7$ - 7 sílabas \\
\hline $\mathrm{X}$ & $9 \times 4-6$ sílabas & $6 / 6 / 6 / 6 / 4 / 10$ & \\
\hline $\mathrm{XI}$ & $7 \times 4$-7 sílabas & $5 / 1 / 5 / 1 / 5 / 1 / 7 / 1$ & \\
\hline XII & $6 \times 4$-7 sílabas & 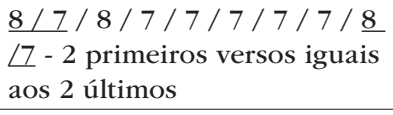 & \\
\hline XIII & $20 \times 4$-7 sílabas & $6 / 8 / 1$ & \\
\hline XIV & $\begin{array}{l}\text { 1.(10/8/6/8 síl.); } \\
\text { 2. (6/8 síl.); } \\
\text { 3. (6/8 síl.); } \\
\text { 4. (6/6 síl.); } \\
\text { 5. (5/7 síl.); } \\
\text { 6. (6/7 síl.); } \\
\text { 7. (6/7 síl.); } \\
\text { 8. (7/8 síl.); } \\
\text { 9. (7/3/7 síl.). }\end{array}$ & & $\begin{array}{l}1.4 \text { x } 7 \text { sílabas; } 2.4 / 7 / 4 \\
1.4 \times 7 \text { sílabas; } 2.4 / 6 / 4 \\
1.4 \times 7 \text { sílabas; } 2.4 / 6 / 4 \\
1.4 \times 7 \text { sílabas; } 2.4 / 7 / 4 \\
1.4 \times 7 \text { sílabas; } 2.4 / 6 / 4 \\
1.4 \times 7 \text { sílabas; } 2.4 / 6 / 4 \\
1.4 \times 7 \text { sílabas; } 2.4 / 6 / 4 ; 3.7 \\
\text { / } 4 \text { / } 5 / 4 ; 4.4 / 7 / 4 \\
\underline{\text { Coplas }} \\
\text { 1. } 6 \times 7 \text { sílabas; } 2 . \underline{6 / 3} ; 3.6 \times 7 \\
\text { sílabas; } 4 . \underline{6 / 3}(=2 .) 7 / 6 / 8 ;\end{array}$ \\
\hline
\end{tabular}




\begin{tabular}{|c|c|c|c|}
\hline Tonos & Estrofes & Estribilho ( ${ }^{\circ}$ de SÍlabas) & Coplas $\left(\mathrm{N}^{\circ}\right.$ de sílabas) \\
\hline XV & $\begin{array}{l}6 \text { x } 4 \text {-7 sílabas; } \\
7.9 \text { / } 7 \text { / } 7 \text { / } 7 \text { / } 7 \\
\text { / } 5 \text { / 5; 8. 9 / 3; } \\
9.4 x 7 \text { sílabas; } 10 . \\
4 \text { / } 5 \text { / 7; 11. a } 13 . \\
4 \text { / 5; 14. a 17.- } \\
4 \times 7 \text { sílabas; 18. } 7 \\
\text { / } 7 \text { / } 4 \text { / 6 / } 5 \text { / } 8 \\
\text { / 9; 19. a 22. 4x7 } \\
\text { sílabas; 23. } 9 \text { / } 10 \\
\text { / 8/10 }\end{array}$ & & $\begin{array}{l}\text { 1. a 2. - 4x7 sílabas; } 3.6 / 7 ; 4 \text {. } \\
5 / 6 ; 5.5 / 7 / 7\end{array}$ \\
\hline XVI & $9 \times 4-7$ sílabas; & $10 / 4 / 4 / 7 / 7$ & \\
\hline XVII & $8 \times 4$-7 sílabas; & $6 / 7 / 7 / 10$ & \\
\hline XVIII & 7 × 4 -7 sílabas; & $7 / 7 / 6 / 4$ & \\
\hline XIX & $6 \times 4$-7 sílabas; & $8 / 7 / 4 / 12$ & \\
\hline $\mathrm{XX}$ & 8 x 4 -7 sílabas; & $4 \times 7$ sílabas; & \\
\hline XXI & 7 x 4 -7 sílabas; & $\begin{array}{l}4 / 6 / 7 / 7 / 7 / 3 / 7 / 7 / 8 \\
/ 7 / 3 / 7\end{array}$ & \\
\hline XXII & 6 x 4 -7 sílabas; & $7 / 6 / 4$ & $\begin{array}{l}1.4 \times 7 \text { sílabas; } 2.6 \times 7 \text { sílabas; } \\
\text { 3. } 7 / 6 / 4\end{array}$ \\
\hline XXIII & 8 x 4 -7 sílabas; & $6 / 4 / 6 / 4$ & \\
\hline XXIV & $6 \times 4$-7 sílabas; & $6 / 4 / 6 / 4 / 6 / 4$ & \\
\hline XXV & 14 x 4 -7 sílabas; & $5 \times 7$ sílabas; & \\
\hline XXVI & 10 x 4 -7 sílabas; & $\begin{array}{l}\text { 1. } 4 \text { x } 7 \text { sílabas; } 2.7 / 7 / 2 / \\
2 / 7 / 7\end{array}$ & \\
\hline
\end{tabular}

$\mathrm{Na}$ maioria dos casos as estrofes são compostas com quatro versos de sete sílabas, que muitas vezes têm acento na quarta e na sétima. Só os Tonos VI, IX [-2] XIV e XV não têm estribilho. Destes, o VI é o único que não tem Coplas e o XIV tem mais quatro estrofes de Coplas a seguir às primeiras, que são sete, cada uma com duas estrofes que têm sempre a mesma estrutura métrica, à exceção da última, que se apresenta com quatro estrofes, mas mantém a estrutura anterior nas duas primeiras.

No Tono VIII, os dois últimos versos do estribilho são o eco da última sílaba do verso anterior. No XII, os dois primeiros versos e os dois últimos do estribilho são iguais. Também no estribilho do Tono XXI há dois pares de versos iguais e, no XXII, são os três versos que concluem as Coplas que repetem o estribilho.

Estes textos entroncam assim nas formas conhecidas dos Vilancicos, com um desenho musical para as estrofes e outro para as Coplas ou o Estribilho, algumas vezes com a repetição do último verso do estribilho nas Coplas - A B. 


\subsection{Autores da Música}

Todos os compositores referidos são músicos importantes no seu tempo, o que mostra quão frutuoso devia ser o trabalho da Academia dos Generosos, que possibilitava o contacto entre os vários expoentes da cultura da época.

\begin{tabular}{|c|c|}
\hline Autores & Tonos \\
\hline Miguel de Herrera & I; II \\
\hline $\begin{array}{l}\text { P.M.F. Felipe / Pelipe de la } \\
\text { M. de D. }\end{array}$ & $\begin{array}{l}\text { III; IV; IX / IX; XIII; XIV; } \\
\text { XVII; XIX; XXIII }\end{array}$ \\
\hline P.M.F. Luis de Cristo & V; VI; XI; XII \\
\hline Gaspar de los Reyos/ Reyes & VII; XVI; XVIII \\
\hline Antonio Marques & VIII; X \\
\hline Iuan Suares Rebelo & XV \\
\hline Esteval de Faria & $\mathrm{XX}$ \\
\hline Marcos Suares / Suarez & XXI; XXII; XXV \\
\hline Felipe de la Cruz & XXIV \\
\hline P.M.F Antonio de I. & XXVI \\
\hline
\end{tabular}

Entre todos só João Soares Rebelo, o Rebelinho, é distinguido como Insigne Maestro Real e "dizia delle o serenissimo El Rey D. João o $4^{\circ}$ que tendo noticia dos talentos de tantos e tão grandes professores de musica, não tinha achado outro que igualasse ao de Rebello» (J. Mazza 1944/45: 31).

Foi grande amigo do Rei e foi a ele que este dedicou a sua Defensa de la musica moderna. Foi músico da capela Real de Vila Viçosa com seu irmão Marcos Soares, que também se distinguiu como Mestre desta Capela e mais tarde da Capela Real.

Frei António de Jesus foi lente na Universidade de Coimbra e estudou com Duarte Lobo. Muitas das obras que compôs constam do catálogo da Livraria de D. João IV (E. Vieira 1900: 498).

Frei Filipe da Madre de Deus viveu em Espanha e, depois da Restauração, voltou para Portugal, desempenhando o cargo de Mestre da música da Real Câmara no reinado de D. Afonso VI (E. Vieira, 1900: 57). Em sua substituição, por se ter ausentado do país, foi nomeado António Marques Lésbio, que, em fins de 1679, foi encarregado de ensinar os moços do coro da Capela Real; mais tarde, este compositor foi também bibliotecário da Real Livraria de Música e, por nomeação de 1698, Mestre da Capela Real (E. Vieira, 1900: 28). 
Gaspar dos Reis foi professor de música, Mestre da Igreja de S. Julião de Lisboa e na Catedral de Braga, cidade onde faleceu.

Frei Felipe da Cruz pertencia à Ordem de Santiago; foi Mestre de Música na Santa Casa da Misericórdia de Lisboa, Capelão da Capela Real de Filipe IV e Mestre da Capela Real de D. João IV (J. Mazza, 1944/45: 22).

Frei António de Jesus foi Mestre de música da Universidade de Coimbra (T. Braga, 1895: 835).

\section{Outros textos que podiam ser musicados}

Nesta obra, nem só os Tonos aparecem como tendo sido "postos em música». A Epístola $\boldsymbol{V}$, na pág. 97 da Fistula de Urania é dedicada a "Francisco Correa de la Cerda, Maestro de Su Alteza». São também referidas as Letrillas, as Comédias em Música, os Romances, os Vilancicos, os Madrigais e as Cançonetas.

\subsection{Letrillas}

Há vários textos chamados Letrilla; em cinco delas está escrito Para cantarse; uma outra chama-se De los Reyes e é um diálogo, com dois intervenientes, sobre o episódio bíblico dos Reis Magos, em que a festa é associada aos instrumentos de sopro:

\section{«De los Reyes. Letrilla LVIII}

1. [...]Alon, alon, alon,

las cornetas le hacen son, las trompas festividades. [...]

[...]1. Llama tu con el clarin, que toca, y llama el albor.

2. Tóca tu, que lo tocas mejor, $\mathrm{y}$ tienes màs retintin. [...]» (Mello, 1665 A Tiorba de Polimnia: 249) 
Na sua maioria, são poemas longos; começam com uma estrofe de quatro versos, que vai depois servir de estribilho; as outras estrofes variam entre os cinco e os dez versos; todas as Letrillas usam a redondilha maior e a rima consoante, seguindo um esquema perfeitamente regular para todas as estrofes do mesmo texto.

A forma musical provavelmente coincidiria com a forma do texto, isto é, música para o estribilho e música diferente para as estrofes, o que apontaria para uma forma de rondó: ABACAD, etc.

\subsection{Comédia em música}

O Romance IX da Avena de Tersicore, tem como tema o mitológico Juízo de Páris e, no título, o autor indica que precedia uma loa para cantar:

«El Iuicio de Paris, preuenido a la loa cantada de una real Comedia. Romance IX."

O texto desenvolve-se em três partes, cada uma com sete estrofes de quatro versos, ditas respetivamente por Juno, Palas e Vénus; a seguir, há uma conclusão dita por Páris, que tem uma só estrofe de seis versos. Dada a referência do título, pode pôr-se a hipótese de este Romance ser também cantado por quatro solistas, como parte de uma representação maior.

Também na Fistula de Urania há alguns textos, que deveriam ser apresentados cantando, ou, pelo menos, teriam a música como suporte. Assim, na página 92 deste capítulo, D. Francisco escreve um Prologo Heroyco, para una Comedia en Musica, ó Drama Cantado., que serviria para uma pequena representação cantada, tão caraterística da época barroca, com artefactos de palco e personagens mitológicas, como pode ler-se nas instruções:

«Baxará desde el ayre en una nube, un gallardo, Pastor que represente la figura de Páris»

"Coro de las Ninfas, prevenido a la Musica del Iuicio de Paris" 
No entanto, não há nada que estabeleça a ligação entre este texto e o Romance IX, referido acima.

\subsection{Romances}

Na Citara de Erato há oito Romances, escritos em quadras, de redondilha maior, que têm no título a indicação de que deviam cantar-se:

«Para musica. Romance I.

Idilio Musico. Romance XVI.

Idilio Musico. Noche de S. Juan. Romance XX:

Al Nacimiento para cantarse. Romance XXVI.

Para cantarse al uso. Romance XXXIII.

Para cantarse al uso. Romance XXXIV.

Para cantarse. Romance $X X X V$.

Musica a una ausente. Romance XLVII."

De um modo geral, são textos longos, que variam entre as doze e as quarenta e cinco estrofes, usando a rima assonante entre o segundo e o quarto versos, exceto nos casos em que há uma, ou várias estrofes que funcionam como estribilho, cuja rima é consoante, e que por vezes têm versos com um número diferente e irregular de sílabas. O Romance. XXVI: Al Nacimiento, para cantarse, apresenta mesmo a divisão entre as estrofes e o Estribilho: Em primeiro lugar, há dez estrofes de quatro versos de redondilha maior, com a habitual rima assonante entre o segundo e o quarto versos; no estribilho, a forma muda: nos primeiros cinco versos, a rima é consoante - aabba; nos oito versos seguintes a rima continua a ser consonante, emparelhada e já aparecem dois versos em redondilha menor, caraterística que vai manter-se até ao fim, embora a rima passe a ser assonante; há depois uma repetição dos primeiros versos do estribilho. Esta forma parece apontar para uma diferença na estrutura da música que se cantava e que, por hipótese, podia ser $\mathrm{AB}$, em que $\mathrm{B}$ teria três partes: cdc.

Também na Avena de Tersicore há treze Romances, cuja medida é sobretudo a redondilha maior - há apenas duas exceções: o Romance II, que alterna 
um verso de seis sílabas com outro de quatro; e o Romance XIII, em que há nove sílabas no primeiro verso e onze no segundo de cada estrofe. Ao contrário dos anteriores, não têm uma indicação expressa de que fossem musicados; há, no entanto, alguns títulos que podem levar a essa conclusão:

"Trauessura a la moda Iacarilla de la muerte de un Iaque. Romance V.

El Iuicio de Paris, preuenido a la loa cantada de una real Comedia. Romance IX.

El Retrato de la bellissima Anarda que ês el setimo del autor, que se ballará en estas Musas. Romance X.

Celebrando al nombre, la hermosura, y la musica de una Dama. Romance XII."

A extensão destes textos varia entre as onze e as trinta e seis estrofes de quatro versos. Em todos os casos, a rima utilizada é assonante, entre o segundo e o quarto versos da estrofe. Estão, assim, em conformidade com a forma dos Romances referidos anteriormente, cuja função era relatar um acontecimento, que algumas vezes era de temática religiosa. Dada a regularidade da estrutura do texto, a forma musical podia ser a simples repetição da música da primeira estrofe, ou então, haver música diferente para cada uma das estrofes, utilizando recursos variados, como por exemplo, cantores solistas, coros e instrumentos, o que poderia ser provável, pela importância e o interesse de que se revestiam estas peças no final do séc. Xvir.

\subsection{Vilancicos}

Os três vilancicos apresentados nesta obra destinam-se à representação do Natal e do Nascimento da Virgem: Al Nascimiento. Villancico XXI; Para la Fiesta de Nauidad. Villancico XXII; A la Natiuidad de la Virgen. Villancico XXIII. Têm, portanto, temática religiosa, como era hábito no século XviI.

O primeiro texto começa com um diálogo entre pastores, que a seguir falam em coro, referindo o ato de tocar, o que pode levar à suposição de que se trataria de um coro acompanhado de instrumentos: 
«[...] Toquen, toquen a olores

Tañan, tañan a flores,

Repiquen a albores. [...]»

Este coro é seguido de Coplas, em estrofes de quatro versos com sete sílabas, que são ditas alternadamente pelos dois primeiros intervenientes e, depois, por um estribilho, que continua a ser em diálogo; finalmente dizem todos o mesmo texto que tinha formado o primeiro diálogo.

O esquema rimático é o seguinte:

\begin{tabular}{ll} 
I & abbbcccddd \\
\hline Todos & eeefffghgh \\
\hline Coplas & ijji \\
\hline Estribilho & klklllm \\
\hline Todos & Igual a I \\
\hline
\end{tabular}

Admitindo uma hipotética correspondência entre o texto e a música, este tipo de estrutura parece apontar para a forma musical ABCDA', ao estilo italiano, em que poderia haver um duo, depois um coro, de novo um duo, que cantaria também o estribilho e finalmente um coro, semelhante ao da estrofe I e com o mesmo texto - D. Francisco nem o escreve na totalidade:

«Ay, ay, ay; Zagalejos.

Que ay? que ay? que ay?

Ay que viene el Mayo, \&c.»

O Vilancico XXII tem uma estrutura completamente diferente: há uma pequena introdução de dez versos seguida por quatro estrofes de nove versos heptassilábicos, que constituem as coplas, cujo último verso forma um refrão, que já estava contido no texto anterior: [...] quien quisiere. [...]

A estrutura do último dos três textos também tem uma introdução, mas só com oito versos. À semelhança do anterior as Coplas têm quatro estrofes de nove versos com sete sílabas, sendo o último o refrão: [...] Sy tu pradillo [...], que também aparecia nos versos introdutórios. 
Estes dois vilancicos adotam o mesmo tipo de estrutura rimática, como pode ver-se no quadro seguinte:

\begin{tabular}{lll} 
& Vilancico XXII & Vilancico XXIII \\
\hline \multirow{2}{*}{ Introdução } & abbaaccddc & abbabccd \\
\hline \multirow{3}{*}{ Coplas } & effeegg hi & effeegg hi \\
\cline { 2 - 3 } & jkkjjll hi & jkkjjll hi \\
\cline { 2 - 3 } & mnnmmoo hi & mnnmmoo hi \\
\cline { 2 - 3 } & pqqpprr hi & pqqpprr hi \\
\hline
\end{tabular}

Ainda por hipótese, a estrutura musical destes dois vilancicos poderia ser $\mathrm{ABc}$, isto é, música para a introdução, música diferente para as coplas e ainda outro desenho musical para os dois últimos versos de cada copla.

Parece assim que estes textos se coadunam perfeitamente com as formas já identificadas de vilancicos que se usavam na época.

\section{Madrigais e cançonetas}

Ainda na Fistula da Urania (pág. 119) há três Madrigais (X, XI, XII), com os títulos Auzencia, La Bienuenida e Huyda que o autor escreve, "para Musica al modo Italiano". São textos curtos; os dois primeiros estão escritos em decassílabos, com estrofes de quatro versos e refrão; o terceiro Madrigal (XII - Huyda) não tem refrão e compõe-se de quatro estrofes de quatro versos undecassilábicos.

A rima tem estrutura semelhante em todos:

$$
\mathrm{X}-\mathrm{abab} / / \mathrm{cc} \quad \mathrm{XI}-\mathrm{abab} / / \mathrm{c} \quad \mathrm{XII}-\mathrm{abab}
$$

Aos Madrigais seguem-se três Cancionetas Balatas, al Modo Italiano, com os títulos El Aurorà, Amor Fingido, buelto verdadero, El Alua y Filis, respetivamente as Cancionetas XIII, XIV e XV. Todas se apresentam em estrofes de quatro versos, alternando com dois, estão escritas em heptassílabos e usam a rima: abab // cc. 
A temática é profana: o amor, a ausência, a aurora.

Tanto os madrigais como as cançonetas têm uma construção semelhante, usando o mesmo esquema para as rimas e um curto refrão no fim de cada estrofe, embora as cançonetas sejam textos mais longos (madrigais - 3 a 4 estrofes; cançonetas - 5 a 7). Esta estrutura, embora nesta época seja mais desenvolvida, parece ter relação com o vilancico primitivo, com a forma apontada por Rui Bessa (2001: 22).

«[Pode] definir-se o vilancico primitivo como uma canção formada de pequenos textos poéticos (vilancetes), de frases curtas e de carácter estritamente popular e profano, musicado com melodias muito simples que o povo cantava nas ocasiões festivas e no seu quotidiano.»

Tendo em consideração que o título indica expressamente al Modo Italiano, pode pôr-se a hipótese de que a música para estes textos, seguindo o modelo dos vilancicos antigos, ou seja, música igual para as estrofes e diferente para o refrão, fosse executada por diferentes cantores, alternando com partes instrumentais.

\section{Bibliografia sumária}

D. Francisco Manuel de Mello (1665), Obras Métricas. Leon de Francia, Horacio Boessat e George Remeus.

E. Vieira (1900), Diccionario Biographico de Musicos Portugueses: História e Bibliographia da Musica em Portugal. Lisboa.

J. Mazza, (1944/1945), Dicionário Biográfico de Músicos Portugueses: extraído da Revista 'Ocidente'.

M. Mersenne (1963), Harmonie Universelle. Paris, 1636. Paris, Editions du Centre National de la Recherche Scientifique.

R. Bessa (2001), O Vilancico: um género musical de Santa Cruz de Coimbra. Universidade de Coimbra, Dissertação de Mestrado.

R. Bluteau (1712-1728), Vocabulário Português e Latino. Coimbra. http://www.ieb. usp.br/online/dicionarios/bluteau. Consultado em 11 de outubro de 2011: 19.25

T. Braga (1895), História da Universidade de Coimbra nas suas relações com a Instrução Pública Portuguesa. Tomo II: 1555 a 1700. Lisboa. 


\author{
Gerhard Doderer \\ Universidade Nova de Lisboa
}

\title{
AS VINTE CANTATAS A DÚO (LISBOA, c1724) DE JAIME DE LA TÉ Y SAGÁU
}

Enciclopédias portuguesas e espanholas dedicaram, até agora, pouco espaço a Jaime de la Té y Sagáu. ${ }^{86}$ No The New Grove's Dictionary of Music and Musicians expuseram-se ainda todas as notícias reunidas por R. Stevenson; ${ }^{87}$ a edição mais recente ${ }^{88}$ não revelou nada que não tivesse sido publicado pelo autor deste artigo, nomeadamente no prefácio da edição da I Parte das suas Cantatas Humanas. ${ }^{89} \mathrm{O}$ ponto da situação encontra-se resumido na última edição da enciclopédia Die Musik in Geschichte und Gegenwart e, parcialmente actualizada, em trabalhos posteriores de G. Doderer. ${ }^{90}$ Assim, o artigo presente baseia-se na mais recente publicação deste autor do ano de 2012.

86 I. F. da Silva (1858), Diccionario Bibliographico. Lisboa, seg., vol. II, p. 256. - E. Vieira (1900), Diccionario Biographico de Musicos Portuguezes. Lisboa, vol. II, p. 268-269. - Enciclopédia Portugueza Ilustrada, vol. 9, p. 621. - Grande Enciclopédia Portuguesa e Brasileira, vol. 26, p. 604. - E. Casares (ed.) (1986), Francisco Asenjo Barbieri-Biografias y Documentos sobre Música y Musicos Españoles (Legado Barbieri), vol. I, Madrid, pp. 473-474.

87 1980, vol. 18, p. 711.

88 M. C. de Brito (2001), vol. 25, pp. 325-326.

89 G. Doderer (1989), "Jayme de la Té y Sagáu e as suas "Cantatas Humanas" (Lisboa 1715/26)", Revista da Faculdade de Ciências Sociais e Humanas, vol. 3, pp. 141-183; idem (1998), "An unknown repertory of the early 18th-century Iberian "Tonos Humanos/Divinos": The Cantatas of Jaime de la Té y Sagáu (Lisboa, 1715-26)”, M. Boyd, J. J. Carreras (ed.) (1998), Music in Spain during the 18th Century, Cambridge, pp. 80-107; idem (1999) (ed.), Jaime de la Té y Sagáu: Tonos Humanos (Sag: I, 1-40), Parte I, vol. I-II, "Portugaliae Musica", vol. 52, Lisboa.

90 Vol. 18 (suplemento), 2008, col. 922-923; (2009) "Jaime de la Té y Sagau e as suas Cantatas de câmara (1715-1725)", Recerca Musicológica, vol. XIX, pp. 121-133; (2012) "Té y Sagáu's 'Officina da Música' in Lisbon: A Music Printing Enterprise exported from Spain to Portugal?”, B. Lolo, J. C. Gosálvez (ed.), Imprenta y edición musical en España (ss. XVIII-XX), Madrid, pp. 111-130. 
Foi Sousa Viterbo quem, nos seus estudos de 1915 e $1932,{ }^{91}$ se ocupou, pela primeira vez, da obra de Té y Sagáu, sem ligar importância de maior a aspectos musicais. Neste contexto é-nos comunicada a opinião de Francisco Xavier Cavaleiro de Oliveira expressa no ano de 1743 :

... D. Jayme de la Te y Sagau, impressor da Musica na Corte de Lisboa, imprimia estas Décadas [= Décadas da Ásia de Diogo do Couto], porem quando sabi de Portugal creyo que naõ estava feita a obra, e depois disso por falta de correspondencia nã̃ sey se se effeituou, o que duvido, considerado o genio, e a patarata daquelle impressor: por fóra cordas de Violla, por dentro paõ bolorento. ${ }^{22}$

A estas palavras, no entanto, se devem contrapor os versos entusiastas de um outro autor coevo, João Cardoso da Costa que escreveu no Romance XLVII: En applauso de D. Jayme de la Té, Y Sagau, quando compuso en metro, y solfa su libro de Cantatas jocosas, sirviendo tambien de assumpto el Prologo de su libro:

YA con la pluma en la mano

Casi me veo indeciso;

Pues no sê, si alabe el metro,

Ó si la solfa del libro. [...]

[...]

Prueba tanto lo que dize,

Que nó pueden los sentidos

Deshazer con evidencia

Lo que su pluma ha exprimido.

Diganlo tambien los metros,

Lo sonoro, lo melifluo;

Con que gracia los adorna

Lo gracioso de su estilo!

91 F. M. Sousa Viterbo (1915), A Litteratura Hespanbola em Portugal. Lisboa, pp. 399-405; idem (1932), Subsídios para a História da Música em Portugal. Coimbra, pp. 540-542.

92 F. X. Cavaleiro de Oliveira (1743), Memóires Historiques, Politiques et Litteraires, concernant le Portugal, et toutes ses Dependances; avec la Bibliotheque des Ecrivains et des Historiens de ces Etats .... Haia, vol. II, pp. 316-317. 
La solfa une a la letra,

Todo tan bello, y tan lindo,

Que mejor nadie lo hará;

Y tambien yó nò lo he visto.

Vivas mil siglos D. Jayme;

Porque es gloria de los siglos

Eternizares tu nombre

Entre harmoniosos prodigios.

Y la embidia se destierre

Del mundo en sus parocismos,

Pues nó se hallan en todo el mundo

Un Jayme como tu mismo.93

Durante a existência da Officina da Música sairam à luz do dia 395 obras impressas, mais de um terço delas de carácter musical. Assim, as diferentes edições musicais, Libretos, Ceremoniais, Processionais e Tratados litúrgico-musicais representam o conjunto tipográfico mais importante de toda a história da Música portuguesa. Além disso, o contributo do compositor catalão é do maior significado em termos quantitativos e qualitativos para a vida musical palaciana da sociedade joanina, revelando novos parâmetros que devem ser relacionados com a vida musical no reinado de D. João V.

\section{Vida}

Relativamente à biografia de Té y Sagáu, Ann Hatherly, num estudo acerca de uma Alegoria Moral ${ }^{94}$ editada na tipografia de Té y Sagáu, resumiu o resultado das investigações realizadas até 1990, por estudiosos no país e no estrangeiro. Ana Cristina Gonçalves Torres apresentou em 2001 uma magnífica Tese de

93 (1736), Musa pueril. Lisboa, pp. 229-231.

94 A. Hatherly (1990), "A Presioza”, de Sóror Maria do Céu. Edição crítica e comentada do Códice 3773 da Biblioteca Nacional de Lisboa, Lisboa. 
Mestrado sobre a tipografia em questão e revelou muitos dados novos. ${ }^{95}$ Nessa base, e utilizando umas escassas informações transmitidas pelo próprio

Té y Sagáu no Prefácio das Cantatas Jocosas, podemos supor que o poeta, compositor e impressor tenha nascido em Barcelona ${ }^{96}$ a 1 de Setembro cerca de 1684, tomando em conta a observação de Té y Sagáu na sua dedicatória nas mesmas Cantatas Jocosas a D. Jaime de Melo, $3^{\circ}$ Duque de Cadaval, como referência ao dia de nascimento..$^{77}$ No entanto, o ano exacto do nascimento permanece ainda desconhecido. Certo é que foi batizado na freguesia de Santa Maria del Mar, em Barcelona ${ }^{98}$ e que faleceu no dia 31 de Março de 1735 em Lisboa. ${ }^{99}$ Nada consta sobre as circunstâncias da sua morte, sabemos apenas que ficou sepultado no Conventos dos Beneditinos da capital. Graças à documentação elaborada aquando do seu pedido de admissão à Ordem de Santiago, ${ }^{100}$ entendemos que era filho de Jayme de la Té y Sagáu, músico que "cantava por estipendio" e que era, aparentemente, a mesma pessoa que se encontra mencionada várias vezes como harpista da corte, bem como nas atas capitulares da Sé Catedral de Barcelona ${ }^{101}$ nos anos de 1683, 1688 e 1689. $\mathrm{O}$ avô paterno (com o mesmo nome do filho e do neto) era um "dançador" e a sua avó é documentada como tendo sido Úrsula Peinado. Todas estas três pessoas eram naturais do Condado de Ruselhó, Principado da Catalunha.

95 (2001), "A Officina da Musica: uma oficina tipográfica portuguesa da primeira metade do século xviıı", 2 vol. (Faculdade de Ciências Sociais e Humanas, Universidade Nova de Lisboa), Lisboa.

96 “... soy Catalán: ela (= a poesia) nacio en Portugal, yo en Barcelona...”, (Cantatas Jocosas, Libro del Acompañamiento).

97 “... El haver nacido ambos en um mismo dia, aun que con diverso influxo, pudo ser acaso; mas yò lo venero como resolucion del mismo Destino ..." (Libro de la Voz, Dedicatória).

98 Assento do matrimónio, Registos Paroquiais, Freguesia de N. Senhora das Mercês, Casamentos, L. 2, fol. 100.

99 Informação obtida muito recentemente e cedida por A. C. Gonçalves Torres.

100 Mesa da Consciência e Ordens, Secretaria da Mesa e Comum das Ordens, Habilitações da Ordem de Santiago, Letra J, Maço 8, Doc. 5. Este e outros documentos como Carta de padrão, Carta de hábito de noviço, Alvará de Cavaleiro, Alvará de hábito de ouro, Alvará de profissão, Registo de matrimónio, Registos de baptismo dos quatro filhos, Provisão para poder fazer imprimir e vender música encontram-se reproduzidos nas pp. 37 a 79 no mencionado trabalho de A. C. Gonçalves Torres (cf. nota 95).

101 J. Pavia i Simó (1986), La música a la catedral de Barcelona, durant el segle XVIII. Barcelona, pp. 296-297; idem (1990), "La Capella de Música de la Seu de Barcelona des del'inici del s. XVIII fins a la jubilació del Mestre Francesc Valls (14-3-1726)”, Anuario Musical, vol. 45, pp. 17-66, aqui pp. 56-57; idem (1997), La Música en Cataluña en el siglo XVIII - Francesc Valls (1671c. - 1747), Barcelona, p. 35. 
Depois de ter abandonado Barcelona, em 1703, ${ }^{102}$ e passado vários anos em Madrid, ${ }^{103}$ Té y Sagáu chegou, no ano de 1706 ou 1707, à capital portuguesa no séquito do jesuíta e diplomata espanhol D. Álvaro Cienfuegos que se deslocou a Portugal para participar nas negociações do casamento de D. João V com D. Maria Ana de Áustria, casamento que se concretizou em 1708. Sob a proteção desse D. Álvaro viveu Té y Sagáu até ao ano de 1715, altura em que obteve, no dia 12 de Outubro, um privilégio real que lhe concedeu o direito exclusivo de produzir e comercializar edições musicais durante dez anos ("para poder fazer impremir, e vender muzica como se fazia na Corte de Madrid e em todas as mais partes da Europa, e que ninguem senão elle podesse ter a d impreça ̃o"). ${ }^{104}$

Já na altura da sua chegada a Portugal começara a compor cantatas em honra da Rainha D. Maria Ana, como documentam duas cantatas conservadas, em forma manuscrita, na Biblioteca Nacional de Lisboa. ${ }^{105}$ Mais tarde destacou-se, graças às suas composições para as festividades no palácio real (1713, Zarzuela $E l$ poder de la armonía para o aniversário do rei D. João V, texto de Luís Calisto da Costa e Faria) e nas igrejas importantes da capital (Oratória: 1719, Sé Catedral e 1722, Convento da Esperança; Vilancicos vários: 1719 a 1723, Sé Catedral; 1719, 1721-22, Igreja de Santa Justa; 1721-22, Convento da Esperança). ${ }^{106}$ Depois de um processo bastante complicado em que se evocou a falta de condições necessárias, foi devido à intervenção da rainha que Té y Sagáu acabou por ser admitido, em 1715, na Ordem de Santiago. No dia 18 de Setembro de 1715 casou-se na Igreja de N. Senhora das Mercês, em Lisboa, com Anna Jozefa Falcata; testemunhas do casamento foram António

102 J. Dolcet (2006), "El Somni del Parnàs, - La música a l'Acadèmia dels Desconfiats (1700-1705)", Tese de Doutoramento, Universitat Autònoma de Barcelona, p. 59.

103 “... La Corte de Madrid fué mi amado domicilio algunos años; yà son diez y nueve los que existo en Lisboa..", (Cantatas Jocosas, Libro del Acompañamiento). Ver também a Provisão para poder fazer imprimir e vender muzica de 31.10.1715: “... que Jayme de La Te y Sagau caualleiro da ordem de Santiago me reprezentou por sua petição que hauia sete annos que se achaua nesta Corte ...”, Chancelaria de D. João V, L. 46, fol. 78, reproduzido em A. C. Gonçalves Torres, op. cit., p. 79.

104 Ver nota anterior.

105 BNL Reservados, Ms Pombalina 82, fol. 19v-21 e fol. 53v; ver também G. Doderer (1999), Parte I, vol. 1, p. XXIV.

106 Libretos das composições citadas conservaram-se no Rio de Janeiro (Biblioteca Nacional; ver R. E. Horch (1969), Vilancicos da Coleção Barbosa Machado. Rio de Janeiro), Coimbra (Biblioteca Geral da Universidade), Évora (Biblioteca Pública), Vila Viçosa (Biblioteca do Palácio Ducal). Ver A. C. Gonçalves Torres, op. cit., pp. 20-21 e os respectivos números no catálogo ( ${ }^{\text {os }}$ $128,129,130,143,144,147,150,155,156,157,159,161,163,166)$. 
Luís de Sousa, Marquês das Minas, e Diogo de Mendonça, Secretário de Estado. Deste matrimónio nasceram, entre 1716 e 1720, dois filhos e duas filhas; ${ }^{107}$ o seu filho primogénito, Jayme Domingos de la Té y Sagáu, herdou a oficina do pai, e figura ainda no ano de 1736 como editor de uma obra literária, muito embora numa outra oficina tipográfica. ${ }^{108}$ Curiosamente, foi Teotónio Antunes Lima, cujas ligações com Jaime de la Té y Sagáu se desconhecem, que aparece, já em 1736, como proprietário da Oficina da Música. A tipografia chegou a designar-se "Oficina da Música de Teotónio Antunes Lima, Impressor da Sagrada Religião de Malta, debaixo da Protecção dos Patriarcas São Domingos e São Francisco", com atividade comprovada entre 1736 e 1741, sempre no mesmo local, ou seja na Rua da Oliveira ao Carmo. No entanto, não se conhecem obras musicais que tenham sido produzidas nesta tipografia.

Diversas casas impressoras com a designação de "Officina da Música" existiam em Lisboa durante as primeiras décadas do séc. XviII. ${ }^{109}$ Entre elas foi, de longe, a "Imprenta de Música” de Té y Sagáu a mais importante, não só em termos quantitativos como também em relação às espécies que daí saíram durante os dez anos do privilégio concedido em 1715. Em vários casos, Té y Sagáu é apontado como autor, não apenas do texto, mas também da parte musical dos acima mencionados vilancicos que, tal como algumas cantatas, seguiram caminho até à Guatemala onde eram executadas ainda em 1788, de acordo com as indicações que aparecem nos respectivos exemplares da Biblioteca da Sé Catedral da Cidade de Guatemala.

\section{Obra e Edições musicais}

Não podemos estar absolutamente certos ao afirmar que as edições musicais devem ter saído do prelo apenas entre os anos de 1715/16 e 1726; o já

107 Todos os pormenores familiares e a respectiva documentação em C. A. Gonçalves Torres, op. cit., pp. 19-20 e Anexo.

108 A. Hatherly, op. cit.; Stevenson, op. cit.; C. A. Gonçalves Torres, op. cit.

109 "Officina de Musica, Lisboa Ocidental", "Officina Joaquiniana de Música de Bernardo Fernandez Gayo", "Officina de Música de Teotónio Antunes Lima”; ver I. Freire de Andrade (1992), "Impressos musicais em Portugal, do séc. xvi aos fins do séc. xvirl", Actas do Colóquio sobre o Livro Antigo. V Centenário do livro impresso em Portugal 1487-1987. Lisboa, pp. 163-173. 
mencionado privilégio do rei para a "Officina da Musica" fora concedido por um prazo de dez anos mas não é de excluir que uma série de peças compostas por Té y Sagáu tenham sido publicadas já antes de 1715. Além das 12 Cantatas de Emanuele d' Astorga que evidenciam a data de 1726, constituindo a última edição musical da Imprenta de Música de Té y Sagáu, apenas a colectânea das seis "Cantatas a solo al Nacimiento" apresenta uma data (1721). ${ }^{110}$

Hoje podem apontar-se não menos que $253^{111}$ cantatas, sacras e profanas, ${ }^{112}$ com texto em língua castelhana, publicadas, em forma de edições individuais ou em colectâneas, por Té y Sagáu na sua "Imprenta de Música" lisboeta.

A autoria de Té y Sagáu está confirmada, até ao momento presente, para 115 Cantatas Humanas (= cantatas profanas), bem como para seis Cantatas Divinas (= cantatas sacras), em muitos casos também no que diz respeito à origem dos textos. Em relação às restantes composições individuais que figuram nos catálogos que Té y Sagáu, em forma de "Lista de los papeles", inseriu nas suas colectâneas (Partes I a IV) pode assumir-se a autoria do mesmo, apesar de não se terem encontrado, até agora, as peças em causa.

A totalidade destas 253 cantatas divide-se em 87 Cantatas Divinas e em 166 Cantatas Humanas. A par de 167 peças para uma voz e 52 para duas vozes encontramos apenas 14 e 20 composições, respectivamente, a três e quatro vozes. Todas as cantatas são providas de uma parte de acompanhamento em forma de baixo cifrado (Acompañamiento), só algumas poucas vezes foi prevista a entrada de instrumentos de arco com funções solísticas.

110 Esta colecção de Cantatas a solo al Nacimiento é citada por Vieira (1900) que a descreve como abrangendo 37 peças, datada de 1721 e pertencendo, naquela altura, à Biblioteca Pública de Évora. Uma tal colecção, que também Stevenson (1980) menciona da mesma maneira, não se deixou localizar na referida biblioteca.

111 Este número não engloba as seis obras que R. Stevenson (1970, Renaissance and Baroque Musical Sources in the Americas. Washington, p. 100) apresenta no seu catálogo do Arquivo da Sé Catedral da Cidade de Guatemala, uma vez que três destas peças são claramente identificáveis como sendo réplicas das Cantatas Humanas e Divinas indicadas na Lista do próprio Té y Sagáu (IV Parte), ao passo que as restantes três parecem ter sofrido uma substituição do texto original ("Indicios da de la cuna", "Los astros que al reir el alva", "Nace el Rey prometido"). De igual modo não fazem parte do número global das composições impressas as duas cantatas profanas "Ai infelise memoria" e "Despues quel pençamiento que siento" do Ms Pomb 82 da Biblioteca Nacional de Lisboa, fol. 19, fol. 53v; ver também nota 105.

112 Té y Sagáu adoptou para as suas obras a designação "Cantata" ao contrário dos seus colegas do outro lado da fronteira ibérica onde se encontra sempre o termo "Tono"; "Cantata Humana" e "Cantata divina" correspondem, portanto, plenamente aos "Tono Humano" e "Tono divino". 
Como acima mencionado, Té y Sagáu juntou a várias colectâneas das suas cantatas uma "Lista de los papeles", q. d. uma listagem das peças deste género que foram produzidas na sua tipografia em datas anteriores, tanto em forma solta como em coleções encadernadas.

Para facilitar a identificação da obra de Té y Sagáu, reproduziu-se uma listagem resumida das composições que se encontram enumeradas no volume do Baixo contínuo da coleção das Cantatas Jocosas, ou seja da IV Parte das "Cantatas Humanas”, no prefácio da edição moderna da I Parte das Cantatas Humanas a Solo (Lisboa 1999). ${ }^{113}$ Deve tratar-se exatamente das mencionadas Cantatas Jocosas que o autor oferece ao Conde de Unhão no dia 16 de Outubro de 1725, fazendo-as acompanhar de uma carta onde fala do Verão deste mesmo ano como data da publicação. ${ }^{114}$ É de notar que uma das colectâneas com 24 cantatas, ou seja a III Parte, não consta da lista que integra as Cantatas Jocosas, q. d. da IV Parte. Em relação aos Cinquenta minuetes que figuram no fim do catálogo, até hoje nada se chegou a saber.

Té y Sagáu organizou a maior parte das suas composições profanas em séries de colectâneas, facto que garantiu a sobrevivência das cantatas nelas reunidas, o que não aconteceu no caso de peças que saíram à luz isoladamente. 90 Cantatas Humanas, organizadas em colectâneas de 40 (= I Parte), 20 (= II Parte), 12 (= IV Parte) e de 3 x 6 (três coleções de 6) peças conservaram-se nas Bibliotecas de Lisboa, de Évora, de Mafra, de Muge e de Madrid. Através das notas e anotações de F. A. Barbieri ${ }^{115}$ chegou-se a ter conhecimento de uma outra coleção de 24 Cantatas Humanas publicada como III Parte por Té y Sagáu, cujo volume de acompanhamento se conseguiu localizar na Biblioteca Nacional de Madrid, ao passo que a respectiva parte vocal se descobriu, por amável intermédio do Prof. Dr. Antonio Moreno, no Arquivo de Compositores Bascos em Rentería.

Relativamente à datação das colectâneas podemos recorrer ao próprio conjunto das 40 Cantatas Humanas a Solo reeditadas no vol. 52 da Portugaliae

113 A "Lista de los papeles" completa, q. d. com as indicações das partes soltas e dos respectivos preços, tal como aparece nas Cantatas Jocosas (IV Parte) faz parte dos trabalhos citados na nota 89 .

114 Reproduzida em A. C. Gonçalves Torres, op. cit., p. 88.

115 E. Casares (ed.) (1986), Biografías y Documentos sobre Música y Músicos Españoles (Legado Barbieri), vol. 1, Madrid, pp. 473-474. 
Musica, obra dedicada "a la Reyna Nuestra Señora Doña Marianna de Austria". Sem indicação de uma data em concreto, encontra-se apenas mencionada que se tratava de uma "Primera Parte", obviamente na intenção de chamar a atenção ("Se está imprimiendo ùn Libro de Cantatas Humanas á Duo.") para outras (futuras) edições. A proteção de que Té y Sagáu gozava por parte da Rainha, privilégio que esteve naturalmente na origem das palavras afectuosas dirigidas pelo compositor a D. Maria Ana, e o facto de ele ter reunido naquela colectânea um conjunto de cantatas em número que não se deixa explicar por qualquer sentido evocativo ou alegórico, levou-nos à conclusão de que a obra foi oferecida e dedicada à Rainha para festejar os quarenta anos que ela completava no dia 7 de Setembro de 1723. Naturalmente e por razões de delicadeza, a idade da soberana não podia constar da edição, mas a evidência das circunstâncias é tão forte que não hesitámos em apontar exatamente aquela data como o ano da publicação destas 40 Cantatas, já que é pouco lícito pensar que uma tal edição poderia ter sido lançada pelo impressor da corte numa altura que não coincidisse com a celebração festiva do aniversário de D. Maria Ana.

Assumido este facto, podemos deduzir com grande probabilidade que Té y Sagáu deve ter iniciado a sua atividade no campo da impressão musical com inúmeras peças avulsas, tendo procedido apenas no ano de 1721 ao lançamento de cantatas reunidas, primeiramente, em pequenas colectâneas, como p. e. as Cantatas a solo al Nacimiento. O grande número de cantatas sacras listadas pelo impressor e o facto de se encontrar Té y Sagáu mencionado frequentes vezes como autor de vilancicos realizados em igrejas e conventos da capital entre 1719 e 1723, permite também deduzir que o género sacro--litúrgico tinha servido em primeiro lugar para prestigiar o compositor. As outras colectâneas maiores onde se reuniram 20, 24 e 12 cantatas devem ter saído depois de 1723 como Segunda Parte, Terceira Parte e Quarta Parte em ritmo relativamente acelerado, ficando pouco claro se estas composições se encontravam já preparadas em anos anteriores, sempre condicionadas pelo evento do aniversário da Rainha, facto que, naturalmente, não teria permitido avançar com qualquer outro senão com este conjunto de composições designado como Primera Parte. Relativamente à neste trabalho focada Segunda Parte - a única colectânea para duas vozes altas e acompanhamento - é possível 
situá-la, no que diz respeito ao seu lançamento, entre Agosto de $1723\left(40^{\circ}\right.$ aniversário de D. Maria Ana) e o Verão de 1725 (edição da Quarta Parte), constituindo estas datas os termini "post quem" e "ante quem".

\section{As Cantatas Humanas a Dúo}

Na edição original, ${ }^{116}$ as vinte Cantatas Humanas a Dúo foram lançadas em três volumes encadernados em pele (formato oblongo $29 \mathrm{~cm}$ x 20,5 cm), destinando-se os dois primeiros às partes vocais ("Primero Tiple", 112 pág. e “Tiple segundo", 108 pág.) com as seguintes portadas:

CANTATAS / HUMANAS A DUO, / COMPVESTAS / POR DON JAYME DE LA TÊ, Y SAGÂU / Cavallero de la Orden de Santiago. / DEDICADAS / AL SERENISSIMO SEÑOR / DON ANTONIO / INFANTE DE PORTUGAL. / PRIMERO TIPLE. / SEGUNDA PARTE. / [vinheta] / LISBOA OCCIDENTAL. En la Imprenta de Musica, / CON PRIVILEGIO. / Se estan imprimiendo varias obras Divinas, y despues de ellas se imprimirà Tercera Parte de obras Humanas.

CANTATAS / HUMANAS A DUO, / COMPVESTAS / POR DON JAYME DE LA TÊ, Y SAGÂU / Cavallero de la Orden de Santiago. / DEDICADAS / AL SERENISSIMO SEÑOR / DON ANTONIO / INFANTE DE PORTUGAL. / TIPLE SEGUNDO. / SEGUNDA PARTE. / [vinheta] / LISBOA OCCIDENTAL. En la Imprenta de Musica, / CON PRIVILEGIO. / Se estan imprimiendo varias obras Divinas, y despues de ellas se imprimirà Tercera Parte de obras Humanas.

O terceiro serve para a execução do acompanhamento em forma de um Baixo contínuo cifrado (112 pág.), intitulado de maneira muito semelhante:

CANTATAS / HUMANAS A DUO, / COMPVESTAS / POR DON JAYME DE LA TÊ, Y SAGÂU. / Cavallero de la Orden de Santiago. / DEDICADAS /

\footnotetext{
116 Publicação moderna programada para o ano de 2013 (Portugliae Musica, vol. 53, Fundação Calouste Guklbenkian, Lisboa)
} 
AL SERENISSIMO SEÑOR / DON ANTONIO / INFANTE DE PORTUGAL. / ACOMPAÑAMIENTO. / SEGUNDA PARTE. / [vinheta] / LISBOA OCCIDEN-

TAL. En la Imprenta de Musica, / CON PRIVILEGIO. / Se estan imprimiendo varias obras Divinas, y despues de ellas se imprimirà Tercera Parte de obras Humanas. / 6U000.
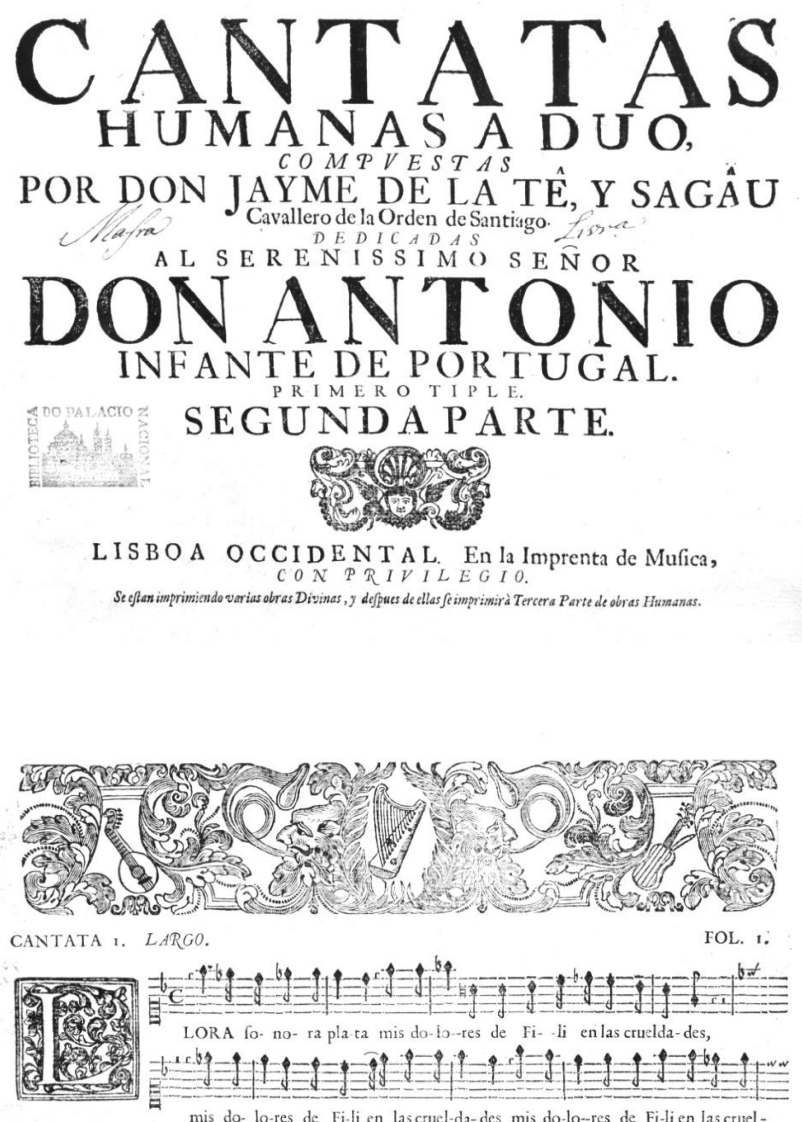
mis do- lo-res de Fi-li en las cruel-da-des mis do-lo--res de Fi-li en las cruel-

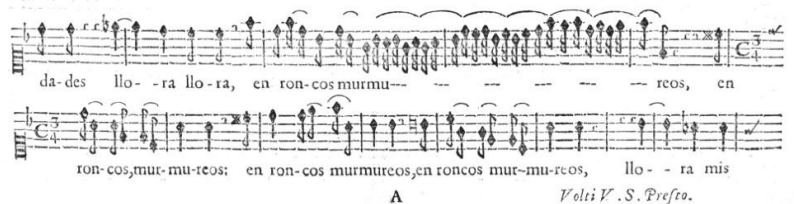

Figura 1 e 2 - Jaime de la Té y Sagáu, Cantatas Humanas a Dúo, Lisboa [c1724], frontispício do volume do Tiple I e início da Cantata I Llora sonora plata 


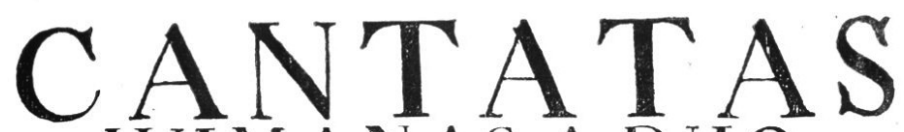

\section{HU M A N A S A DU O,}

POR DON JAYME DE LA TA TE, Y SAGÄU

$D E D I C A D A S$

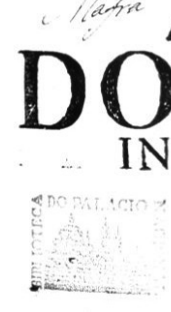

AL SERENISSIMO SENOR

INFANTE DE PORTUGAL.

T I PLE SEGUNDO

SEGUNDA PARTE.

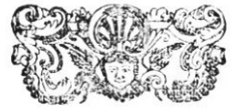

LISBOA OCCIDENT A L. En la Imprenta de Mufica; C $0 N$ P R I V I L E G IO.

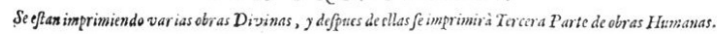
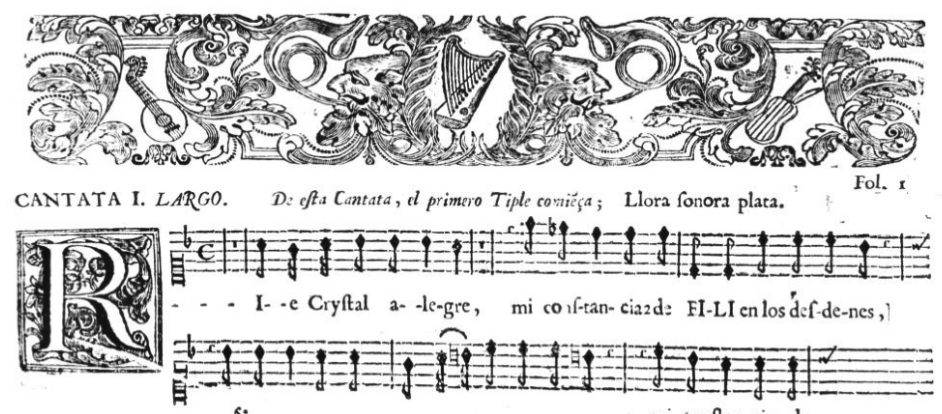

s.

mi conftan-cia de

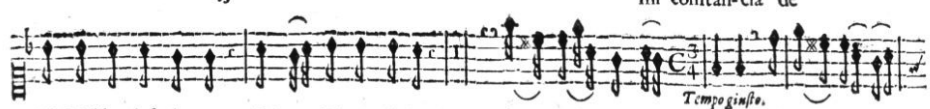

FI-LI é los def-de-nes, Ri-e, Ri-e, Ri-e; En quic-brospe- - renncs, en quicbros pe-

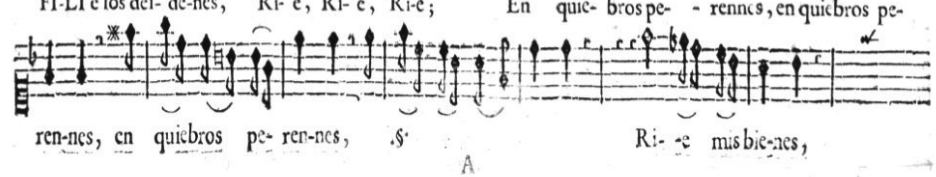

Figura 3 e 4 - Jaime de la Té y Sagáu, Cantatas Humanas a Dúo, Lisboa [c1724], frontispício do volume do Tiple II e início da Cantata I Llora sonora plata 


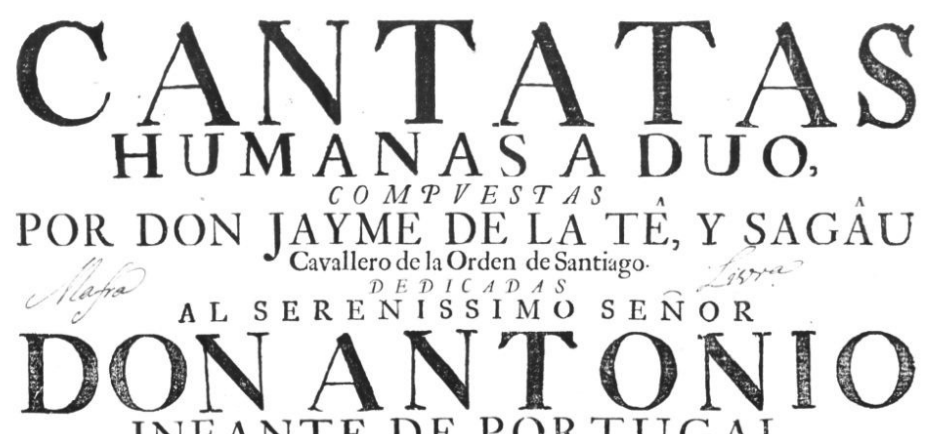

INFANTE DE PORTUGAL.

$A C O M P A \widehat{N} A M I E N T O$

SEGUNDA PARTE.

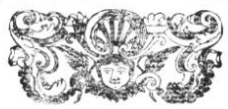

L I B O A O C CI D E N T A L. En la Imprenta de Mufica,

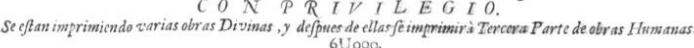

Fol. $x$ :

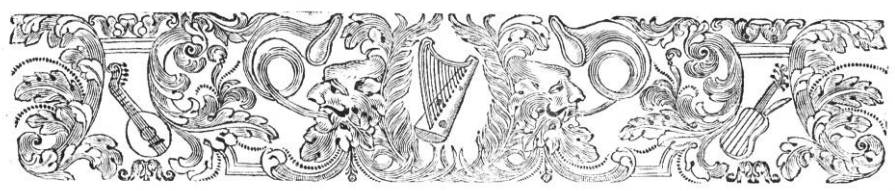

CANTATA I. LARGO. De efta Cantata, el fegunlo Tiple: dize. Rie cryftalalegre,\&c.

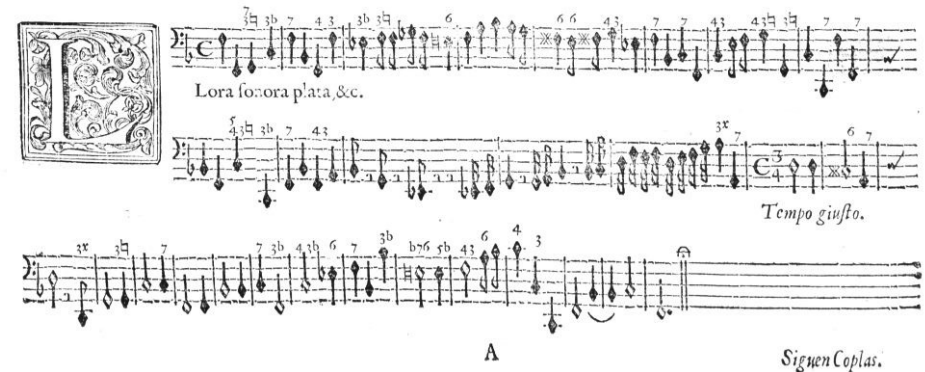

Figura 5 e 6 - Jaime de la Té y Sagáu, Cantatas Humanas a Dúo, Lisboa [c1724], frontispício do volume do Acompañamiento e início da Cantata I Llora sonora plata (Fotografias de G. Doderer com autorização da Biblioteca do Palácio de Mafra) 
Tal como as outras colectâneas de Té y Sagáu, também as Cantatas Humanas a Dúo são dedicadas a uma personalidade da mais alta nobreza portuguesa, no caso presente ao Infante D. António, o irmão mais novo do Rei D. João V. Muito bem conhecido pelas suas inclinações artísticas e capacidades musicais, D. António fez-se notar várias vezes em momentos importantes da vida musical do país, como p. e. aquando da sua deslocação a Itália onde, no ano de 1714, traçou os destinos de Domenico Scarlatti como futuro Mestre de Música do Palácio da Ribeira ${ }^{117}$ (e professor de cravo para si próprio) ou quando estabeleceu contactos vitais na corte do Grão Duque de Florença onde exercia a sua atividade o genial construtor de instrumentos, Bartolomeu Cristofori. É bem significativa a dedicatória que Té y Sagáu dirige a D. António na sua obra, antecipando as palavras apologéticas que, de uma forma bem longe de meras expressões laudatórias subservientes, o real mecenas iria receber no prefácio das famosas primeiras composições para o então novo pianoforte, as Sonate da Cimbalo di Piano e Forte publicadas por Lodovico Giustini di Pistoia em Florença, no ano de $1732 .{ }^{118}$

No volume do acompanhamento das nossas vinte Cantatas Humanas a Dúo encontramos, logo a seguir à portada, um prefácio formulado pelo próprio Té y Sagáu:

Serenissimo Señor,

ESTE Libro de Cantatas á Duo busca con ansia reverente en la Real proteccion de VUESTRA ALTEZA la seguridad, de ser grato á todos. No tube que hazer en la eleccion de Patron tan Soberano, haviendo de darle al publico; pues el esplendor del SERENISSIMO NOMBRE DE VUESTRA ALTEZA illustrando tanto mi idea, que en estos Numeros se representa; basta para hacer, que hasta al vulgo parezca acorde su proporcion, y armonia. Todo este Reyno sabe com admiracion, (y lo van sabiendo los estraños con embidia) que el SERENISSIMO GENIO DE VUESTRA ALTEZA desde sus primeros años empeçò á inclynar su SOBERANA IDEA á la

117 G. Doderer (2009), "Remarks on Domenico Scarlatti's Portuguese Period (1719-1729)" in L. Morales (ed.), Domenico Scarlatti in Spain, Almería, pp. 161-183, aqui pp. 162-163.

118 Cf. G. Doderer (2002), "As Sonatas de Lodovico Giustini di Pistoia, Florença 1732: A Primeira Edição para o Pianoforte" in Lodovico Giustini de Pistoia - Sonate da Cimbalo di Piano e Forte, Rio de Janeiro, pp. 9-27. 
armonia, haviendo empezado Real entretenimiento, lo que oy se venera Magisterio consumado: trasladando á las expressiones del Clavicordio, los conceptos armonicos de la FECUNDA REAL FANTASIA DE VUESTRA ALTEZA con tanto acierto, y destreza en las manos, como si governase cada dedo una inteligencia, y con aquel buen gusto que sabe dar á todas sus acciones un Numen Divino: excediendo venturosamente, lo que por noticia de San Isidro era en la antiguedad documento: pues deseando, que en sus Heroes, por mayor ornato, no se descubriese la torpe ignorancia de la Musica, VUESTRA ALTEZA no solo sabe de esta noble facultad lo que basta para diversion; si no lo que puede servir de enseñanza.

Esta consideracion, y el Real acogimiento que VUESTRA ALTEZA se ba servido hazer á muchas de mis composiciones, dignando-se de entretenerse con ellas algunas horas, me anímam a consagrar, y poner baxo la Soberana inscripcion del SERENISSIMO NOMBRE DE VUESTRA ALTEZA estas Cantatas: y quando careciessen de lo armonioso, nadie podrá negarme, la consonancia que haze esta Dedicatoria con mi esclavitud; y que està muy acorde con mi obligacion mi respeto; pues tambien como en la Musica no puede en el reconocimiento, y veneracion, haver sin distancias armonia. DIOS guarde la SERENISSIMA PERSONA DE VUESTRA ALTEZA, quanto sus criados necessitan.

DON JAYME DE LA TÈ, Y SAGÀU.

Cada um dos três volumes possui um índice com a extensão de duas páginas ("Tabla") inserido depois da portada no caso dos livros dos Tiples e, no volume do Acompañamiento, introduzido a seguir ao prefácio acima reproduzido. Este prefácio é ainda completado por umas listagens das obras publicadas por Té y Sagáu até à altura do lançamento das Cantatas a Dúo. A "Lista de los papeles divinos, y humanos a solo, a duo, a tres, y a quatro con violines, violones, y sin elles ..." enumera os títulos dos "[Tonos] Divinos", ou seja: 25 obras para voz solística, 32 para duas vozes e 18 composições para quatro vozes, naturalmente, todas com acompanhamento. Na secção dos "Humanos" figuram 24 obras a solo, para além de uma menção das Quarenta Cantatas en dos libros [= Parte I], 11 Duos, 3 Tercios e 2 Quatros, seguindo-se uma página com a "Lista de los papeles enquadernados" que abrange 6 Solos 
al Santissimo, 6 Solos al Nacimiento, 3 vezes 6 Solos Humanos e a indicação de Cinquenta Minuetes; no fundo desta mesma página avisa-se que "Se està imprimiendo tercera parte de obras humanas à Solo".

Mas o volume do Acompañamiento ganha ainda uma importância especial devido à reprodução de todos os textos das 20 cantatas da edição (pp. 83 a 112), bem como graças à inserção de umas advertências que dizem respeito à execução do acompanhamento da última Ária da Cantata XX (pág. 82):

Adviertese, ser sumamente difficil (a la primera vista) el Acompañamiento de esta ultima Aria, en qualquiera Instrumento; especialmente en el Arpa, cuya execucion, ès impossible, sin valerse del dedo Anular; pues solo con los otros tres que regular, y generalmente se usan en dicho instrumento, es cansarse en valde pretender executarla. En el Clavicordio, serà algo menos dificil; por raçon de tocarse este instrumento con todos los dedos de ambas manos: y constando los arpeados de esta Aria de quatro notas, aun sobra un dedo para la euxecucion [sic]; pero siempre (por raçon de las distancias) tendrà gran difficultad. En el Violon, serà difficultosissimo; por lo irregular de los trasportes de la mano, sin los quales, no puede haver seguridad en la afinacion, y para conseguir esta (que es el origen de la armonia) es preciso capacitarse de todos los secretos, que encierra en si el Mastil. El estudioso, que a desvelos de su aplicacion los haya adquirido, aun necesitará de un continuo, mental cuydado, para no çoçobrar en el tempestuoso mar de tan successivas dificultades.

No ignoro, ser muy dilatada, y que en mi eleccion estuvo el remedio; pero, advirtiendo que era el ultimo periodo de esta obra, dexè correr la idea quanto quiso, por los campos de la fantasia asta que me pareció justo clausular.

Estas observações são bem esclarecedoras no que diz respeito aos instrumentos que podem servir para a realização do baixo contínuo: o compositor exclui a utilização da harpa a não ser quando se possa empregar a técnica do uso do dedo anelar e coloca grandes reservas relativamente à Viola da Gamba 
(ou ao Violoncelo) devido às dificuldades de afinação, admitindo, no fundo, apenas o cravo ("clavicórdio" conforme a tradicional terminologia castelhana) como meio de concretização satisfatória. É pelo teor da advertência, exclusiva à última Ária da Cantata XX, que ficamos a saber quais os instrumentos que o compositor realmente considera para a execução das suas obras, ou seja harpa, "violón” e cravo. De estranhar é o facto de não estar mencionado o pianoforte apesar das frequentes indicações relativamente a contrastes dinâmicos ("piano", "forte") exigidos ao instrumento destinado a realizar o baixo contínuo.

É também neste mesmo livro do Acompañamiento que aparece, no conjunto dos textos das vinte Cantatas (ver listagem abaixo), a identificação dos autores dos Textos ("Poesias"). Entre eles, dois são responsáveis por três quartos da totalidade dos vinte textos e são-nos conhecidos através da sua colaboração com Té y Sagáu: Julião Maciel, membro do Cabido da Sé Catedral de Lisboa, e Luís Calisto de Costa e Faria - até 1724 funcionário da casa do Visconde de Vila Nova de Cerveira, tendo recebido depois ordens de presbítero do Hábito de S. Pedro - irão ainda contribuir com novas poesias para a Terceira Parte das Cantatas; o último já tinha composto libretos para comédias musicais e zarzuelas representadas na corte lisboeta nos anos de 1712-1713. ${ }^{119}$ Os restantes textos (um deles em anonimato) das Cantatas a Dúo foram atribuídos a Pedro Vaz Rego, mestre reputado da Capela da Sé Catedral de Évora, a Francisco Botelho de Vasconcelos e ao próprio Té y Sagáu.
1. Llora, sonora plata (Texto: Julião Maciel)
2. Nereides bellas (Texto: Francisco Botelho de Vasconcelos)
3. Dulcemente gime (Texto: Pedro Vaz Rego)
4. Quejoso Amor se lamenta (Texto: Julião Maciel)
5. Miró a Matilde el Amor (Texto: Julião Maciel)
6. Tente, arroyuelo infelize (Texto: Julião Maciel)
7. Del rigor de un desvío (Texto: Julião Maciel)

\footnotetext{
119 Fabula de Alfeo y Aretusa, 1712; Son Triunfo de Amor los Zelos, 1712; El Poder de la Harmonia, 1713.
} 
8. Para rendir más suave (Texto: Julião Maciel)

9. Cuando aviva su incendio (Texto: Julião Maciel)

10. ¿Hombres, dónde se albergan compasiones?

(Texto: Luís Calixto de Costa e Faria)

11. Claros arroyos (Texto: Luís Calixto de Costa e Faría)

12. Yo pensé que era alivio (Texto: Julião Maciel)

13. Dulce tirano (Texto: Autor anónimo)

14. Corred, fuentecillas (Texto: Jaime de la Té y Sagáu)

15. Impiedosa beldad (Texto: Luís Calixto de Costa e Faria)

16. Al rigor de una ausencia cruel (Texto: Luís Calixto de Costa e Faria)

17. Juzgaba yo (Texto: Jaime de la Té y Sagáu)

18. Lisonjera inquietud (Texto: Luís Calixto de Costa e Faria)

19. De Amor, en el mar (Texto: Luís Calixto de Costa e Faria)

20. Estrella enemiga (Texto: Luís Calixto de Costa e Faria)

\section{Forma e estrutura das Cantatas}

Entre as particularidades musicais e formais das Cantatas Humanas deve apontar-se, em primeiro lugar, a sequência dos andamentos que, de forma alguma, se demonstra minimamente normalizada. O esquema estrutural é quase sempre variado, tanto em termos numéricos como em termos de combinação sequencial, e tem como elementos constituintes Árias, Recitativos e Coplas, para além de secções formalmente menos definidas, designadas de Prelúdio, Introdução ou apenas com o carácter do Andamento (p. e. Grave, Larguissimo, etc.). Numa combinação sequencial totalmente livre encontram-se cantatas com apenas dois andamentos ao lado de outras com oito. No entanto, a Ária e o seu antecedente Recitativo parecem constituir, de acordo com o omnipresente modelo italiano do fim do séc. XVII/princípio do séc. XVIII um tipo de "módulo base" que é alargado através de duplicações ou até triplicações (R1-A1-R2-A2 ou R1-A1-R2-A2-R3-A3); este esquema enriquecido 
fica sujeito, por sua vez, a uma série de diferentes processos de variação formal, processos que incluem substituições e aumentos por meio de outras secções formais. Neste contexto, é atribuído às Coplas um papel de grande importância, pois servem não apenas como elemento estrutural, quase aleatório em termos da sua colocação múltipla (inicial, central ou final), mas também como tradicional reminiscência formal que evoca, a todo o momento, a vivência das estrofes do Vilancico.

Com esta surpreendente liberdade estrutural contrasta uma fascinante tendência para criar determinadas áreas formais que ultrapassam, em aspectos conceituais, todos os outros andamentos. Nas Árias, Té y Sagáu pouco ou nada se afasta do $D a$ Capo habitual, atribuindo à primeira parte uma clara e muitas vezes desequilibrada preponderância dimensional em desfavor da segunda parte. Para além da sua múltipla inserção entre os outros andamentos das cantatas, as Coplas apresentam-se às vezes com uma secção final transitória, semelhante a um recitativo, particularidade que juntamente com ocasionais familiaridades motívicas em relação às secções antecedentes - evidencia o intuito de alcançar uma maior unidade do conjunto da peça. No já referido afastamento do modelo tradicional, devido à introdução e entrelaçamento de andamentos ou secções mais complexas, onde se sucedem, em semelhança à construção do Moteto, diversas mini-secções de caracter arioso e recitado (divergentes em termos de "afectos musicais", de pulsações e movimentações rítmicas e de contornos melódicos), pode reconhecer-se a intenção do compositor de criar momentos de uma expressão dramática mais abrangente, afastando-se do rigor formal das tradicionais "árias de número" barrocas. Neste sentido não é de estranhar que as extensões globais das cantatas, abrangendo p. ex. no caso das nossas Cantatas Humanas a Dúo peças de 189 a 529 compassos, nem sempre possam ser sintomáticas para a existência de poucos ou muitos andamentos; assim, verificamos cantatas com seis ou sete secções (andamentos) e apenas 169 a 187 compassos, respectivamente, e, por outro lado, obras com três andamentos que atingem os 422 compassos.

No quadro anexo oferece-se uma visão clara em relação aos andamentos e às estruturas destas Cantatas, bem como relativamente à sua construção tonal, aos números de compassos e à configuração rítmica. 


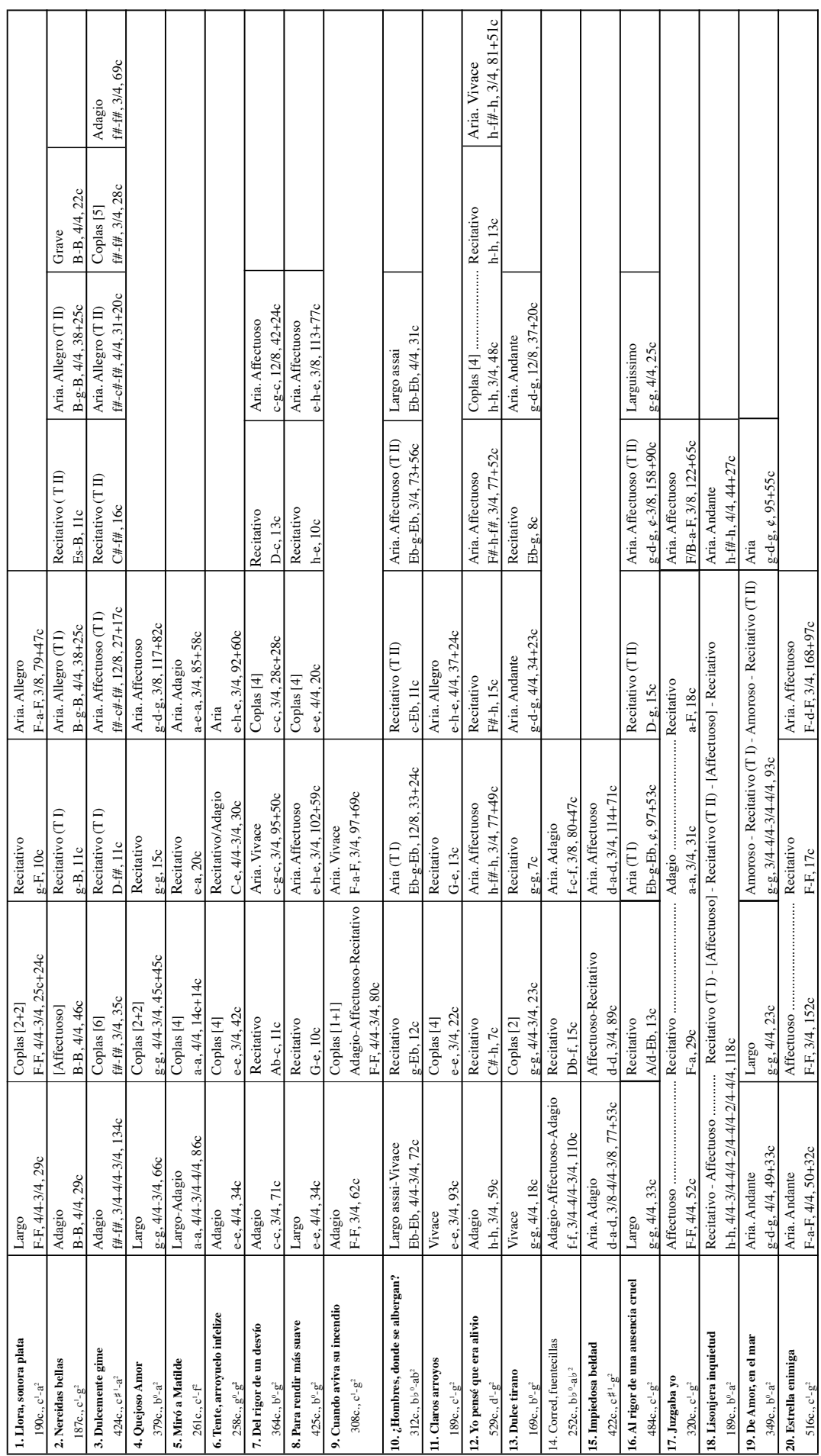


Té y Sagau deve ter encontrado a inspiração para proceder desta maneira não tanto nas cantatas de Scarlatti, Bononcini ou Händel, mas antes e de uma forma bem evidente na construção estrutural dos Tonos Humanos, em voga nos anos de ca. de 1700, da autoria de Pedro Rabassa, Francisco Valls, Sebastián Durón, José Torres e Antonio Literes, ou seja de compositores ligados a Valencia, Barcelona e à Capela real de Madrid. ${ }^{120}$

\section{Linguagem idiomática}

Tanto as quarenta Cantatas Humanas da I Parte, como os vinte Cantatas Humanas a Dúo da II Parte evidenciam uma série de particularidades idiomáticas, quer no seu conjunto quer também nas suas ocorrências isoladas. A Cantata de Câmara da época de Té y Sagáu, um género musical bem cultivado e omnipresente nos salões da alta sociedade barroca, circulava em moldes que tinham recebido um cunho próprio graças a autores como Alessandro Scarlatti, Giovanni Bononcini ou Emanuele d' Astorga, e oferecia, para além disto, grande flexibilidade e abertura em termos formais e estilísticos, factos que a tornaram bem atraente para os compositores meridionais. Foi certamente este último factor razão muito forte para o nosso compositor, pois que se verifica nas mencionadas obras uma variedade de elementos formais e musicais, de forma tal que a sensação de coerência conjuntural das duas colectâneas se obtém mais sob o aspecto literário do que sob o aspecto musical.

O texto em língua castelhana evoca muitas vezes o ambiente pastoril com personagens mitológicas e alegóricas, estando sempre presente o sofrimento e o tormento amorosos originados pela crueldade da figura amada que provoca assim a infelicidade do poeta. Embora condicionado pelas convenções da lírica barroca em uso na sociedade joanina daqueles anos, Té y Sagáu consegue encontrar muitas vezes imagens e descrições onde transpiram

120 J. J. Carreras (1997), "La cantata de cámara española de principios del siglo XVIII: El manuscrito M 2618 de la Biblioteca Nacional de Madrid y sus concordancias”. In María Antonia Virgili Blanquet, Germán Vega Garcia-Luengos, Carmelo Caballero Fernández-Rufete (ed.), Música y literatura en la península ibérica: 1600-1750. Valladolid, pp. 65-126; idem (1998), "Spanish cantatas in the Mackworth collection at Cardiff". In M. Boyd, J. J. Carreras (ed.), Music in Spain during the Eighteenth Century, pp. 108-122; idem (2001), "Cantata, V: The Spanish cantata to 1800", The New Grove Dictionary of Music and Musicians, vol. 5, pp. 37-40, aqui pp. 38-39. 
sentimentos sinceros e humanos, não deixando de lado evocações humorísticas. A preferência por este género de tema literário irá refletir-se, mais tarde e durante muitas décadas, nos milhares de versos das Modinhas dos compositores portugueses e brasileiros dos séculos XVIII e XIX.

Té y Sagáu atinge uma considerável força de expressão musical personalizada no campo das linhas melódicas que, a miúdo, fazem lembrar as de Pergolesi e Händel. Temas e motivos evidenciam uma tendência para ficarem reduzidos e encurtados no decorrer dos andamentos e afinidades melódicas entre os motivos principais dos vários andamentos das cantatas são relativamente frequentes. Sempre concebidas em íntima relação com a métrica e a acentuação da poesia, as melodias das Cantatas Humanas a Dúo foram construídas com vigor e flexibilidade, ricas em espontaneidade insinuante, entrando facilmente no ouvido. Para além de uma cuidadosa periodização, quase sempre marcada em unidades de quatro compassos com as suas respectivas divisões e duplicações, as linhas melódicas de Té y Sagáu caracterizam-se por uma morfologia que corresponde ao conteúdo do texto, recorrendo, em termos iguais, a fórmulas curtas ou ao encadeamento de um considerável número de grupos de colcheias ou semicolcheias, a saltos (até ao intervalo de nonas) ou a progressões em graus conjuntos. As partes vocais contemplam para o Tiple e o Contralto a extensão de sol $^{0}$ até ao lá ${ }^{2}$. Sequências são bem frequentes mas não utilizadas em excesso, sendo normalmente duas repetições do motivo em causa consideradas suficientes para sublinhar duplicações de frases parciais do texto. Nas obras para duas vozes nota-se uma tendência para quadruplicar o número de motivos sequenciais, obviamente com a finalidade de obter, através da repetição em duplicado, o efeito de eco ou de "pergunta-resposta". As linhas melódicas ajeitam-se sempre à textura literária, nunca admitindo qualquer discrepância entre ambas no que diz respeito à acentuação, mesmo quando as frases se apresentam em fragmentos ou nas repetições de palavras. Em muitos casos, palavras realçadas e apresentadas várias vezes encontram novas colocações dentro das unidades métricas, sem perder, no entanto, a sua acentuação literariamente correta.

Tanto nas Cantatas para uma voz como para duas vozes e acompanhamento deve ser sublinhado o papel particular do Baixo contínuo com as antecipações motívicas nos inícios dos andamentos e das diferentes secções, 
constituindo-se não apenas como base harmónica omnipresente mas também como parceiro complementar no enredo imitativo das vozes. Tiple I e Tiple II /Contralto apresentam desenhos motívicos que se baseiam em pré-imitação e imitação regular, formação em pares, cruzamento das vozes e alternância entre condução sucessiva-imitativa e paralela. Figuras rítmicas, hemiolização, "wordpainting" e o rico repertório de figuras da "Affektenlehre" caracterizam incessantemente a escrita de Té y Sagáu.

Relativamente ao conteúdo musical e à sua configuração artístico-expressiva observa-se uma certa irregularidade nos patamares qualitativos, tanto no que diz respeito à colecção na sua globalidade como também quanto aos andamentos que constituem o conjunto de cada uma destas Cantatas: peças extremamente bem conseguidas alternam com outras menos entusiasmantes e várias das Cantatas surpreendem-nos devido ao contraste entre os seus andamentos, uns à altura dos grandes mestres da época e outros sem notável inspiração ou brilhantismo. Nota-se uma maior e quase espontânea leveza de expressão musical na forma como o compositor formula o ductus musical e harmónico quando se trata de tonalidades menores que ultrapassam, numericamente, as tonalidades maiores, facto que se pode observar também na obra de alguns outros compositores lusos ativos na mesma época em que as Cantatas de Té y Sagáu foram concebidas.

\section{Madrid - Lisboa}

Por enquanto, de nenhuma documentação dispomos que nos possa esclarecer relativamente à relação direta de Té y Sagáu com Madrid, ou seja com as pessoas da Capela Real e, em primeiro lugar, com José Torres Martinez Bravo. ${ }^{121}$ As suas declarações sobre a estadia em Madrid são mais que escassas mas é mais que evidente que a Imprenta de Música de Torres que tinha iniciado as suas atividades em 1699 com a publicação dos Destinos vencen finezas, da autoria de Juan de Navas, serviu de modelo e inspiração comercial

121 B. Lolo (2001), "Torres y Martínez Bravo, Joseph de". In: The New Grove Dictionary of Music and Musicians, vol. 25, pp. 635-637.; idem (2002), "Torres y Martínez Bravo, Joseph de". In: Diccionario de la Música Española e Hispanoamericana. [Madrid], vol. 10, 2002, pp. 409-42. 
e artística para o jovem Catalão. Ao começar a produzir música impressa para os músicos lisboetas, Té y Sagáu seguiu obviamente os parâmetros que encontrara em Madrid para as edições de peças de menor porte, tanto no que respeita ao formato do papel e à apresentação dos frontispícios como à organização dos textos musicais. Se bem que as características comerciais e conceituais da sua Oficina se assemelhassem muitíssimo às da Imprenta de Música madrilena, as edições musicais propriamente ditas não podiam assumir as mesmas dimensões e - intencionalmente - abranger os mesmos géneros musicais. ${ }^{122}$ Às composições impressas durante o período do privilégio concedido, procurou-se conferir um alto nível de qualidade gráfica; todo o tipo de pautas, de caracteres musicais e das cifras das partes de acompanhamento distingue-se claramente do material utilizado por Torres em Madrid. Salta à vista que o conjunto dos elementos do grafismo musical e a sua configuração em geral aparenta uma grande semelhança com a célebre edição das Flores de Musica de Manuel Rodrigues Coelho, produzida em Lisboa por Pedro Craesbeeck no ano de 1620. Futuras pesquisas hão-de fornecer mais clareza sobre este ponto, como se deve esclarecer, também, até que ponto um hipotético relacionamente entre Té y Sagáu e José Torres justifica apontar uma exportação de um modelo ou de um projecto de Madrid para Lisboa; certo é que houve uma transferência de conceitos e tecnologia, uma "transplantação" de uma árvore ainda bem tenra que, no entanto, cresceu, ramificou e deu muito fruto em terras lusitanas.

\section{Conclusão}

Durante a existência da Officina de Música na propriedade de Té y Sagáu sairam à luz do dia 395 obras impressas, 42,8\% delas de carácter musical. Assim, as Cantatas Humanas - e entre elas as vinte Cantatas Humanas a Dúo como expoentes máximos - e as outras edições musicais, bem como os Libretos, Ceremoniais, Processionais e Tratados litúrgico-musicais representam o

122 B. Lolo (1988), La Música en la real Capilla de Madrid: José de Torres y Martinez Bravo (b. 1.670-1.738). Madrid, pp. 101-126. 
conjunto tipográfico mais importante de toda a história da Música portuguesa. Além disso, o contributo do compositor catalão é do maior significado em termos quantitativos e qualitativos para a vida musical palaciana da sociedade joanina, revelando novos parâmetros com os quais se deve identificar a vida musical no reinado de D. João $\mathrm{V}$, em relação à qual se tem negado, até há pouco e de maneira quase absoluta, aspectos relevantes de carácter profano.

\section{Bibliografia}

Costa, J. Cardoso (1736), Musa pueril. Lisboa.

Carreras, J. J. (1997), "La cantata de cámara española de principios del siglo XVIII: El manuscrito M 2618 de la Biblioteca Nacional de Madrid y sus concordancias", in María Antonia Virgili Blanquet, Germán Vega Garcia-Luengos, Carmelo Caballero Fernández-Rufete (ed.), Música y literatura en la península ibérica: 1600-1750. Valladolid, pp. 65-126.

(1998), "Spanish cantatas in the Mackworth collection at Cardiff", in M. Boyd, J. J. Carreras (ed.), Music in Spain during the Eighteenth Century, Cambridge, pp. 108-122.

E. Casares (ed.) (1986), Francisco Asenjo Barbieri - Biografias y Documentos sobre Música y Musicos Españoles (Legado Barbieri). Madrid.

Doderer, G. (1989), "Jayme de la Té y Sagáu e as suas "Cantatas Humanas" (Lisboa 1715/26)", Revista da Faculdade de Ciências Sociais e Humanas, vol. 3, pp. 141-183.

(1998), "An unknown repertory: The Cantatas of Jaime de la Té y Sagáu (Lisboa, 1715-26)" in M. Boyd, J. J. Carreras (ed.) (1998), Music in Spain during the 18th Century, Cambridge, pp. 80-107.

(1999), Jaime de la Té y Sagáu: Tonos Humanos (Sag: I, 1-40), Parte I, "Portugaliae Musica", vol. 52, Lisboa.

(2002), "As Sonatas de Lodovico Giustini di Pistoia, Florença 1732: A Primeira Edição para o Pianoforte" in Lodovico Giustini de Pistoia - Sonate da Cimbalo di Piano e Forte, Rio de Janeiro.

Dolcet, J. (2006), "El Somni del Parnàs, - La música a l'Acadèmia dels Desconfiats (1700-1705)", Tese de Doutoramento, Universitat Autònoma de Barcelona.

Hatherly, A. (1990), "A Presioza”, de Sóror Maria do Céu. Edição crítica e comentada do Códice 3773 da Biblioteca Nacional de Lisboa, Lisboa.

B. Lolo (1988), La Música en la real Capilla de Madrid: José de Torres y Martinez Bravo (b. 1.670-1.738). Madrid

Oliveira, F. X. Cavaleiro de (1743), Memóires Historiques, Politiques et Litteraires, concernant le Portugal, et toutes ses Dependances; avec la Bibliotheque des Ecrivains et des Historiens de ces Etats .... Haia. 
Pavia i Simó, J. (1986), La música a la catedral de Barcelona, durant el segle XVIII. Barcelona.

(1990), "La Capella de Música de la Seu de Barcelona des del'inici del s. XVIII fins a la jubilació del Mestre Francesc Valls (14-3-1726)", Anuario Musical, 45, pp. 17-66.

(1997), La Música en Cataluña en el siglo XVIII - Francesc Valls (1671c. - 1747), Barcelona.

Viterbo, F. M. Viterbo (1915), A Litteratura Hespanhola em Portugal. Lisboa.

(1932), Subsídios para a História da Música em Portugal. Coimbra.

Torres, A. C. Gonçalves (2001), "A Officina da Musica: uma oficina tipográfica portuguesa da primeira metade do século xvıI", Tese de Mestrado, Faculdade de Ciências Sociais e Humanas/Universidade Nova de Lisboa, Lisboa. 


\section{Márcio Páscoa}

Universidade do Estado do Amazonas

\section{EZIO DE NICCOLO JOMMELLI PARA LISBOA: MEDIAÇÃo ENTRE A TRADIÇÃO E A INOVAÇÃo}

Em 1753, gozando do auge da fama, Niccolo Jommelli (1714-1774) já havia produzido quase quatro dezenas de óperas, algumas em segunda versão, dentre o gênero sério e cômico, para diversos palcos italianos, os mais prestigiosos. A repercussão de sua obra trouxe-lhe convites de Mannheim e Lisboa, declinados em favor de Stuttgart. O que parece ter-lhe atraído nesta proposta foi a possibilidade de trabalhar coros, balés e conjuntos concertantes, uma vez que o gosto francês nos nobres mandatários desta cidade já estava sendo cultivado a certo tempo. Isto não impediu o autor italiano de desenvolver parceria com Lisboa, já iniciada no ano de 1751 (McClymonds, 1980: p. 20), pelo que consta da existência de libreto desse ano para um componimento drammatico com música de sua autoria.

Embora não tenha se favorecido de tantas obras líricas em estréia como a corte germânica, Lisboa assistiu à montagem de 25 trabalhos de Jommelli, excetuando-se composições de menor dimensão, volume provocado pelos altos encômios, sobretudo na fase em que a relação do autor italiano com Stuttgart se desgastou e ele teve de retornar a Nápoles.

Dentre as óperas criadas especialmente para Lisboa, contam-se, dois trabalhos maduros, a festa teatral L'avventure di Cleomede, de grande dimensão e liberdade formal, e Il trionfo di Clelia, cuja repercussão chegaria ao autor apenas um mês antes de sua morte. Além disso, houve uma encomenda especial, para que o compositor fizesse uma nova versão de Ezio, de Metastasio.

Ezio foi uma escolha pessoal de Dom José e envolvia grandes dificuldades. Em correspondência a Gaetano Martinelli, libretista de sua confiança que 
ele fizera empregar em Lisboa para cuidar dos aspectos de montagem de sua obra, Jommelli confidenciaria:

Ó Deus, quando eu penso que eu tenho de escrever de novo esta ópera, e que eu tenho ainda mais de a escrever para um Soberano ilustrado, Conhecedor, que tem toda a outra Música minha, feita para as mesmas palavras, isto me dá febre. Eu amo, venero e me ajoelho diante do adorado Metastasio e toda a sua obra, mas gostaria que também ele, adaptando-se à moda, fizesse algo novo, assim como é o desejo de todo o mundo querer o mesmo. Assim, posto que eu tenha de extrair tantas diferentes idéias, não somente diferentes das já feitas nas mais vezes, mas também daquelas de outros tantos Compositores, sempre e sempre sobre as mesmas palavras; é coisa para fazer a cabeça rodar, ainda que a tivesse de bronze. Basta. Eu me recomendarei a Apolo e à minha amada Euterpe. (Idem, pp. 487-488)

Com uma enormidade de títulos apresentados ou adquiridos para os próprios arquivos, a ópera de corte no reinado de Dom José fora feita por interveniência direta do soberano nas escolhas mais diversas, de recursos humanos e materiais, de temas e gostos ali praticados. Mesmo que não fosse ele uma figura de elogiável atributo físico, o carisma que concentrava todas as atenções, era considerado conversador erudito ainda que modesto (Monteiro, 2006: p. 65).

Compreendidas as colocações de Jommelli na carta a Martinelli, a respeito do rei português, cabe ainda refletir pelo segundo aspecto do temor do músico. O libreto de Ezio já havia sido trabalhado por ao menos outros 32 compositores além de Jommelli, e a bem da verdade outros 11 ainda o fariam até a derradeira criação de Mercadante em 1827.

Mas com exceção deste último e de Anfossi, nenhum outro autor posterior a Jommelli foi alguém da mesma nomeada. O que preocupava Jommelli seguramente eram as significativas marcas precedentes que obraram sobre o tema. Quando ele fez a sua primeira versão de Ezio, o primeiro grande trabalho de Metastasio que ele abordaria, outros oito autores já se haviam arriscado no tema, dentre os quais Porpora, Hasse e Handel. E até a data em que recebeu a comissão para Lisboa, nomes da envergadura de Sarri, Traetta, 
Graun, Galuppi, Bertoni, De Majo e até Perez, haviam estreado sua versão de Ezio, e Sacchini, Gazzaniga e Guglielmi estavam a preparar a sua.

Havia ainda exigências adicionais de Dom José, que logo de início encarregara Martinelli em escrever uma opera seria "de acordo com o gosto moderno, mas sem representação de bailados» (McClymonds: p. 601) e que o argumento viesse de "qualquer Fábula, ou História, na qual possam entrar tercetos, quartetos, quintetos» (Idem).

O próprio rei dias mais tarde escolheria Ezio como sendo o libreto em questão e a data de 6 de junho de 1771, seu aniversário, foi estabelecida como a estreia desta nova versão, cabendo prioridade em sua composição perante a da ópera de argumento totalmente novo, que viria a ser L'avventura di Cleomede.

Botelho, diretor dos teatros reais, informou que o libreto de Ezio havia sido encurtado pela mão do próprio Metastasio (Idem).

Mas quando Jommelli recebeu o libreto de Ezio, já modificado por Martinelli, é difícil crer que Metastasio concordasse com o que ali estava. O célebre poeta discordaria de outra adaptação, feita por Saverio Mattei, em Ezio naquele mesmo ano, para música de Sacchini. Metastasio refere-se a um quarteto inserido no segundo ato como sendo decente e bem feito, e que dependendo dos cantores podia ser bastante eficaz para os efeitos dramáticos, mas que isso encurtaria o ato, deixando aos dois personagens principais apenas uma ária cada. (Carta de Metastasio a Mattei in McClymonds.)

Isto teria sido um sacrilégio, quando eu o escrevi, mas nos presentes dias, quando nossos cantores heróicos, têm cedido a responsabilidade de uma bem sucedida representação a bailarinos, e quando por virtude desta cessão, a ópera tem se tornado intermezzi para as danças, quanto mais se corta um drama, menos matéria permanece para exercitar a paciência dos espectadores. Por outro lado é falso supor que eu já tenha feito um quarteto para o Ezio e mesmo que eu já tenha sido pedido a fazê-lo.

Parece assim claro que Metastasio não aprovaria também a versão de Martinelli, que também inseriu um quarteto no fim do segundo ato, eliminando árias de vários personagens, como fizera Mattei. A confusão, entretanto, pode ter vindo do próprio Mattei, que afirmou posteriormente ter Metastasio escrito 
uma nova ária para Fulvia, a pedido de Jommelli, para aquela produção de Lisboa. (Idem, p. 198) Trata-se certamente da ária Tenneró per l'idol mio, inserida na cena sétima do segundo ato em lugar de Quel fingere affetto. Jommelli confirmaria em carta a Martinelli que recebera o libreto do amigo ainda em novembro de 1769 , e que, embora sem ter se detido nele, havia considerado que estava muito bom, dando a entender que não havia ninguém entre eles na feitura do Ezio de Lisboa.

A versão de Martinelli para Jommelli tem vários cortes com o fito de promover o citado quarteto no final do segundo ato e ainda um dueto no final do primeiro ato.

Quadro 1 - Comparativo de cenas e árias entre o libreto de Metastasio, 1728 e o de Martinelli, 1772.

\begin{tabular}{lccccc} 
& \multicolumn{2}{c}{ Ezio: Metastasio, 1728 } & \multicolumn{2}{c}{ Ezio: Martinelli, 1772 } \\
\cline { 2 - 5 } & Cenas & Árias & Cenas & Árias/ensembles \\
\hline Ato 1: & 13 & 10 & 10 & 6 \\
\hline Ato 2: & 16 & 10 & 10 & 8 \\
\hline Ato 3: & 15 & 8 & 10 & 4 \\
\hline
\end{tabular}

Quando recebeu o libreto de Ezio em novembro de 1769, Jommelli estava ocupado escrevendo árias para La schiava liberata e ainda por boa parte do primeiro semestre de 1770 , para La Nitteti, ambas destinadas à Lisboa, com adaptações específicas para os cantores e a orquestra da corte portuguesa.

Ezio deveria ter sido acabada em novembro de 1770, de modo a que pudesse estar nas mãos de Dom José em dezembro daquele ano. Mas houve vários motivos de atraso. O primeiro deveu-se seguramente à doença do compositor, que o impossibilitava periodicamente de trabalhar, agravada por sangrias receitadas pelo médico. As pendências financeiras de Stuttgart, ou seja, a recusa de Carl Eugen de Wurtenberg em pagar o acordado com o compositor, deve ter sido o principal motivo para Jommelli passar a escrever óperas para o Teatro San Carlo de Nápoles também naquele ano, o que trouxe preocupação a Botelho.

É verdade que em outubro já estavam prontos todos os recitativos, simples e acompanhados, da ópera, assim como a sinfonia, a marcha e o coro. 
Entretanto, esta que seria a primeira remessa, estava com seu envio atrasado porque Jommelli esperava concluir o primeiro ato para que o rei português não visse a ópera em pedaços. (Idem)

Obviamente, a pressão de Nápoles para que Jommelli escrevesse Demofoonte roubava tempo precioso para cumprir o contrato com Lisboa. Ainda assim, ele conseguiu despachar para Portugal, através de Gênova, a partitura completa e autógrafa de Armida abbandonata, um grande sucesso daquele mesmo ano.

O primeiro ato de Ezio seguiu somente em 20 de novembro daquele ano de 1770 (McClymonds: p. 527). Mas em fins de janeiro de 1771, diante da surpreendente notícia de que o compositor estava engajado também numa ópera para Roma, as cobranças de Lisboa aumentaram (Idem: p. 630) A chegada de uma correspondência em 22 de fevereiro, contendo apenas os recitativos do segundo e do terceiro atos, levou Botelho à indignação:

Quem diria senhor Jommelli que ao invés de receber o resto de toda a ópera Ezio eu iria encontrar apenas os recitativos do ato $2^{\circ}$ e $3^{\circ}$ que o senhor agora me manda, sem nenhuma das árias respectivas? Quem não esperaria uma simples falta, por causa das suas deploráveis doenças acenadas do senhor, mas se se vêem três óperas feitas em Itália, por outros teatros? Quem podia imaginar, que o senhor Jommelli preferiria o venal teatro de Roma ao Real Teatro de S.M.F. [Sua Magestade Fidelíssima] que lhe providenciou uma pensão de 400 zecchini, que lhe foram acrescidos depois de se contentar com 300? (Idem, p. 632)

Como o aniversário da rainha era em 31 de março e por causa do cancelamento da restante temporada do carnaval pelo falecimento da princesa Maria Francisca Doroteia, Botelho decidiu que o aniversário real assistiria a Semiramide riconosciuta e a data de Ezio seria o natalício de Dom José, a 6 de junho.

Botelho esperou até o último momento a chegada das restantes árias de Ezio, talvez postadas em correspondência perdida que Jommelli reclamou ter enviado pelo correio espanhol em dezembro de 1770, janeiro e fevereiro de 1771 (McClymonds: p. 106). 
O aniversário do rei foi preenchido com La clemenza di Tito e, para sorte de Jommelli, o agrado real foi tanto que Dom José deixou que a falta de Ezio apenas se resumisse numa reprimenda ao compositor e não na quebra de contrato como Botelho avisara (Idem).

Após vários revezes, a composição de Ezio seria concluída em 1771 e entrou enfim em ensaios no ano seguinte, indo à cena em 20 de abril de 1772, a comemorar o aniversário da rainha; Botelho comentou em carta a Jommelli que «os músicos acharam-na [a ópera] muito bonita e pelo que espero que Suas Magestades tenham motivo de admirar sempre mais o seu particular talento." (McClymonds 1980: p. 658).

Curiosamente, nem toda a música desta versão de Ezio é nova. Os motivos para isso podem ter sido os contratempos relatados nas cartas entre Botelho, Martinelli e Jommelli, levando-se em conta a pressão por compor algo mais para libreto tão demandado. Entretanto, após tantas faltas, mesmo que abonadas por sucessos levados à cena, pareceria imprudente da parte do italiano que apresentasse um conjunto em que figurassem árias já conhecidas, causando certo descrédito das suas faculdades criativas, conforme comprovadamente ele temia. Mas houve material que foi simplesmente reaproveitado e permanece incerto qual o contexto em que isto se inseria agora em 1772, se no de um procedimento de pasticcio de si mesmo praticado por Jommelli, ou se revisitando aspectos estilísticos mais antigos com intenções estéticas de obter contraste ou reforço retórico sobre algum personagem.

Por exemplo, a ária de Fulvia, Non son io che parlo, no final do Ato III, é quase igual desde a versão de Nápoles (1748), tendo passado por Stuttgart (1758) e chegado à versão de Lisboa (1772), com acréscimo de trompas e oboés, uma parte mais independente de viola, sendo que houve também uma troca de da capo para dal segno. Entretanto, o recitativo que lhe antecede na composição da cena, Misera dove son, foi inteiramente refeito desde a versão napolitana, ainda que tenha permanecido a ideia de ser um obligatto. Jommelli quis manter no plano de cena a ideia original, para enriquecê-la, atualizá-la esteticamente, mas na verdade a escrita homorrítmica muito em voga três décadas antes, já podia ser considerada algo datada. A menos que significasse manutenção de valores que se associava à personagem de grande retidão moral que é Fulvia. 
Como apenas esta cena e mais três árias e um dueto sobrevivem da versão de Stuttgart, pouco se pode saber sobre o material imediatamente prévio que Jommelli realmente aproveitou para a versão de Lisboa. A distância entre a estreia de Lisboa e a de Nápoles, de 24 anos, não deve ter favorecido aproveitar muito mais que as árias do terceiro ato, todas com características de obras mais antigas.

Ainda assim, a preocupação primeira de Jommelli foi com os recitativos. Deviam carregar o drama e a sua feitura correta muito ajudaria no sucesso da obra, no aspecto dinâmico, teatral dela. O compositor decidiu-se certamente onde eles ganhariam estrutura seca, apenas suportada pelo baixo contínuo, ou acompanhada pela orquestra, à vista de terem sido substancialmente modificados pela adaptação de Martinelli. Esse parece ter sido um ponto de preocupação de Jommelli em anos precedentes também, quando fazia em média quatro obbligatti a cada ópera e chegou a dobrar esta conta em produções anteriores.

Jommelli escreveu seis obbligatti em Ezio. Tais recitativos visam dar maior poder dramático à cena e, portanto, localizam-se todos em situações de grande tensão. O primeiro está no encontro de Ezio e Valentiniano logo no primeiro ato e antecede a primeira ária deste último. Ainda neste ato, na primeira cena de Massimo há outro obbligatto, assim como na cena do dueto, em que o par central está sob grande pressão. Da mesma forma, ocorre no quarteto final, onde Valentiniano chama Ezio à sua presença para atribuir-lhe a punição. O imperador quer que Ezio veja Fulvia a seu lado. Mas esta, não podendo mais suportar a simulação revela a todos que ama Ezio. Neste momento o recitativo seco converteu-se em obbligatto, acompanhando a subida de tensão no conflito vivido pelos personagens.

Fulvia ainda está envolvida em mais um obbligatto na sua cena solo do terceiro ato. Costumeiramente apenas os papéis principais têm recitativos deste tipo que lhes são atribuídos, mas Jommelli escreveu um para a cena solista de Varo, onde se encontra a única ária a que ficou reduzido este personagem nesta versão de Lisboa.

As árias, ainda que se possa flagrar material pré-existente, de um modo geral tiveram um tratamento diferente do que à época da versão napolitana. Em alguns casos elas são diametralmente diferentes. A primeira ária do personagem 
titular, Pensa a serbarmi, o cara foi modificada completamente desde a última versão disponível e mesmo o caráter mais juvenil desta música mudou para algo mais maduro e reflexivo na versão de Lisboa.

Há outros aspectos inovadores nesta versão de Ezio para Lisboa. A textura orquestral tende a exceder a divisão em três partes, que era comum neste repertório, especialmente até meados do século. Tais opções comumente incluíam: colla parte de violinos e linha vocal, com viola e baixo contínuo desempenhando partes independentes; e colla parte de violino 1 ou 2 com o solista de canto, enquanto viola e baixo contínuo desempenham a mesma linha.

Jommelli escreveu passagens em textura a 4 vozes, tornando o violino 2 independente e atribuindo uma parte de viola diferente do baixo contínuo. Neste caso a linha vocal dobra a melodia do primeiro violino. O exemplo abaixo vem da ária Nocchier che si figura (Ato I), de Massimo, onde se pode ver o fim de uma seção, marcada pela fermata e o início de um verso que sugere uma escrita psicologicamente mais densa.

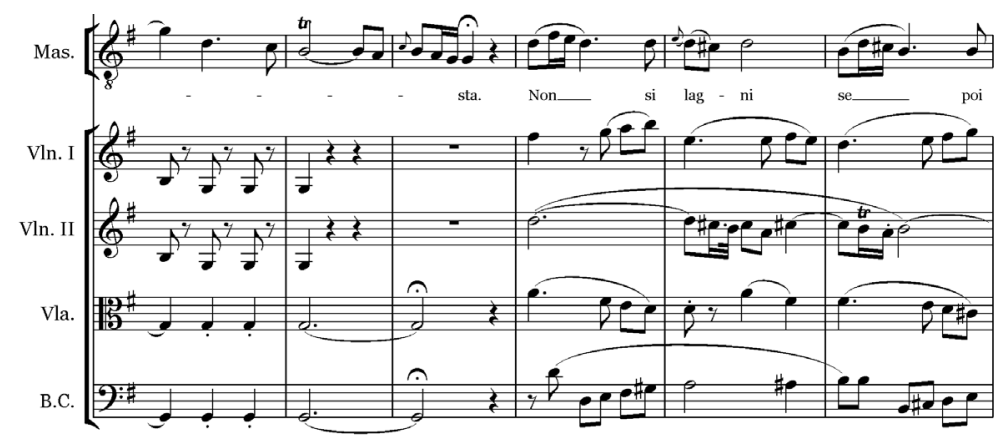

Neste caso, não só as vozes têm independência de notas como tendem a um contraponto bem mais rico do que experimentavam muitos outros autores.

Outra possibilidade de obter uma textura mais rica era pela inclusão eventual de um instrumento solista. O violoncelo é uma escolha natural em diversos autores por ser um elemento destacável do baixo contínuo sem que ocorra prejuízo de orquestração como a princípio se poderia pensar da escolha das demais partes. Assim, o autor chega a obter uma textura a 4 partes, como acontece na ária de Onoria, Quanto mai fellice siete (Ato I) 


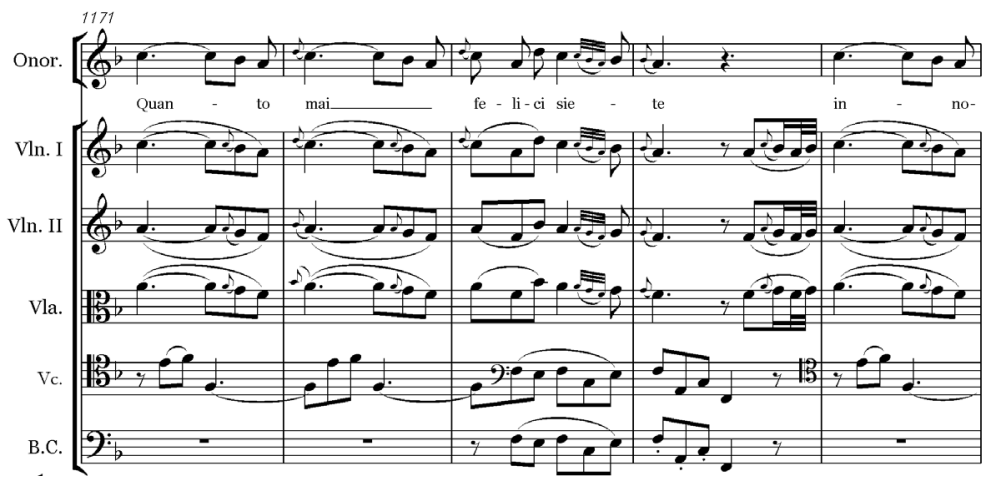

A ária de Onoria simula ainda a idéia de textura a 5 partes por alternar a presença do baixo contínuo com o violoncelo solo. Neste caso a linha vocal continua em colla parte com o primeiro violino.

Entretanto, uma escolha mais ousada vem da mesma ária de Massimo citada acima, em que a textura a 5 partes existe realmente, pois a parte das cordas foi escrita com independência entre si e da linha de canto. O apoio do cantor neste caso está na escrita rítmica coincidente com parte de violino 1 e 2 que pode se alternar como referência ou se manter por mais tempo tendo um naipe como escolha. Viola e baixo contínuo permanecem com escrita independente todo o tempo.

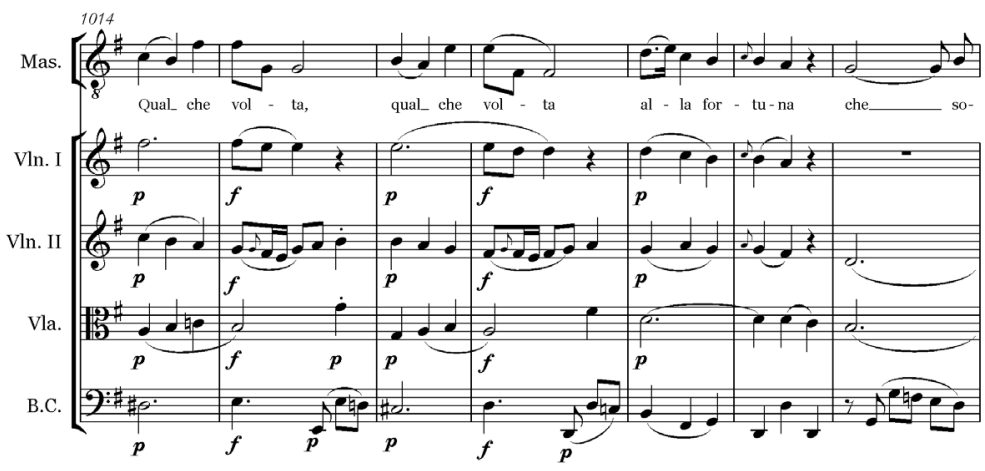

A orquestração de um modo geral é mais rica nas óperas que Jommelli fez para Lisboa, em parte porque ele já possuía uma orquestra bastante seleta em 
Stuttgart, para quem escreveu muitos anos, mas também porque a orquestra de Dom José era ainda maior e mais variada que a do Duque Carl Eugen.

Sob a ótica de vários observadores, a Orquestra da Real Câmara de Lisboa estava entre as melhores se não era a melhor de seu tempo, casos dos testemunhos de Richard Twiss, William Beckford, duque de Chatelet, James Murphy e Adrien Balbi, todos em função diplomática ou militar oficial na capital portuguesa, a escrever memórias posteriores de suas viagens.

Richard Twiss, em particular, escreveu sobre uma performance de Ezio que assistiu em 1772: Eu estive em 17 de novembro no Palácio do Rei em Belém, cerca de cinco milhas de Lisboa, e ouvi a ópera italiana Ezio executada lá. A orquestra consistia de instrumentistas muito habilidosos (Twiss 1775: p. 10).

Jommelli escreveu 9 das 16 árias de Ezio usando oboés e trompas na orquestração, assim como no coro final, na sinfonia de abertura e na marcha, onde além destes incluiu partes independentes para duas flautas. Muitas passagens ao longo da ópera mostram também que o baixo contínuo previa fagotes. Entretanto não há menção alguma a clarinetes, o que completaria o naipe das madeiras, talvez porque Jommelli não os possuísse em Stuttgart e não tivesse o hábito de escrever para tais instrumentos. Ainda assim eles estavam disponíveis na orquestra de Dom José.

O aspecto morfológico das árias escritas por Jommelli em Ezio também reforça a ideia de que se trata de trabalho daqueles últimos anos, em que ele varia consideravelmente de opções e tende a constituir conjuntos mais escorreitos e sem interrupções para mudança de andamento ou caráter.

Não há mais nenhuma ária com a indicação da capo e apenas a citada ária de Fulvia tem a observação dal segno. Quase todas ainda remetem ao padrão $a b a$, ternário composto, com uma seção $a$ dividida em dois $\left(a, a^{\prime}\right)$ por causa da repetição da primeira quadra da ária transitando de tônica para dominante. Algumas vezes o retorno após a seção $b$ traz mais variantes de $a$, podendo haver $a$ " e $a$ "'. Oito árias ainda têm uma seção $b$ definida, com mudança de andamento e formulação de compasso, sendo algumas dentro de ambiente tonal estável. Entretanto outra parte considerável possui elisão entre as seções de modo a não fazer parar o percurso da música. Este procedimento também facilitou a flutuação tonal na escrita de algumas delas, que 
gozam de maior sinuosidade melódica e mais expressividade na disposição do texto sobre a música.

Mas em alguns destes casos, Jommelli também variou o andamento com a inserção de fermatas ou indicações eventuais neste sentido, alterando também os aspectos rítmicos da escrita. Isso pode ter relação com a escolha dos andamentos. Ao menos 6 árias têm a indicação de Andante e Andantino Affetuoso. Embora o Allegro apareça como a escolha comum às demais árias, ao menos 3 delas têm a ressalva complementar de Moderato e algumas ainda têm a indicação de non Presto. Em quase todos os casos as seções internas das árias caem para andamentos mais lentos, como o Andantino.

As indicações de forte e piano, a Jommelli atribuídas como sendo um precursor de seu uso, parecem estar mais relacionadas aqui aos acentos musicais de determinadas passagens, para criar um sotaque correto do discurso musical pretendido. Assim os acentos auxiliam o entendimento do discurso musical e são coerentes com o discurso verbal desenvolvido pelo cantor.

Entretanto, como a versão de Lisboa é uma cópia da mão de João Cordeiro da Silva, o diretor da Orquestra da Real Câmara, é especulável que tais sinais podem variar pela aplicação da idéia de similaridade entre trechos que o autor escreveu e onde podem ser aplicados. No mesmo sentido, há um grande número de ligaduras, sendo boa parte delas para agrupar mais que as notas, abrangendo as ideias musicais de uma passagem ou seção, antecipando tendências românticas.

Jommelli tem nisto e noutros elementos já citados uma proximidade com a escrita musical centro-europeia do tempo, especialmente na preferência por desenvolvimento harmônico sofisticado e até mesmo alguma flutuação cromática. Algumas árias inclusive começam na dominante para se acomodar na tônica e não são raras as passagens em que se encontram as mudanças cromáticas «bruscas», o que se pode verificar nas duas primeiras árias de Fulvia.

A escolha do formato de árias compostas (ternária ou binária) favorece tais ideias, em que uma seção elide na outra, ou mesmo quando ele recorre à alteração da ordem das palavras nos versos, causando efeitos de tensão, ou prolongamento das ideias musicais (Por ex: ária de Fulvia, Tenneró dell'idol mio, Ato II). 
Há uma atribuição parcimoniosa das árias de bravura. Das árias de Valentiniano, seguramente a primeira Se tu la reggi al volo, é a que requer maior demanda de agilidade, não obstante a cadência da ária So chi t'accese precisar de especial cuidado. As duas árias entretanto têm aspecto bastante diferente. Ambas no primeiro ato servem a momentos e características distintos da composição dramática. A primeira explora o caráter impulsivo do imperador, com sua seção central bastante contrastante, representando a sua vacilante e temerosa personalidade. A segunda ária já é marcada por uma escrita pontuada e um andamento bem menos rápido, dando um ar de ária parlante que Jommelli explorou de diversas maneiras em sua obra.

Ezio também possui coloraturas, especialmente nas árias do segundo e terceiro ato. Nesta última em especial, embora uma ária curta para os padrões, os trechos exigem uma voz leve, ainda que no todo, o personagem esteja num registro mais baixo que Valentiniano e Fulvia. Mas Ezio é caráter mais moderado e portanto sua ornamentação é equilibrada e menos exibicionista do que outros papéis similares em óperas do mesmo autor, em tempos passados.

As árias de Fulvia têm demanda de agilidade, mas relativas a cadências de passagem, acabamentos de frase, notas embelezadas, sequências de grupetos, mas nenhuma grande seção melismática como em Ezio ou Valentiniano. O mesmo ocorre com Onoria, embora ela possua esse caráter de bravura, na sua ária do segundo ato.

Todos os papéis, exceto Massimo, foram escritos usando a clave de dó na primeira linha, embora Valentiniano e Fulvia sejam classificáveis atualmente como sopranos, Ezio como um meio-soprano ou soprano grave, e Varo possa ser desempenhado por soprano mais leve. Massimo teve sua música escrita na clave de dó na quarta linha, conforme a convenção da época em que o tenor sendo o registro mais grave da distribuição vocal, assume o caráter do vilão.

O coro, de caráter epigramático, possui uma repetição do texto, numa formulação homorrítmica e de estrutura $a, a^{\prime}$.

A Marcha, bem como a Sinfonia, teve escolhas tradicionais de estrutura. Esta, em três partes, possui um primeiro movimento segundo um modelo de forma-sonata. O movimento central é um cantabile para cordas, estando o terceiro movimento concebido à maneira dos Vivace e Presto do tempo, com estrutura de $3 / 8$ ou $6 / 8$. 
Quadro 2 - Aspectos elementares gerais das árias

Título

Tonalidade Tempo Andamento

Forma

\begin{tabular}{llllll}
\hline Ato 1 & \multicolumn{1}{l}{ Sol M } & $4 / 4 ; 3 / 4$ & $\begin{array}{l}\text { All non Presto/ } \\
\text { Andantino }\end{array}$ & aba \\
\hline Valentiniano: & Se tugi al volo & Sol & & And \\
Ezio & Pensa a serbarmi o cara & SibM & $4 / 4$ & $\begin{array}{l}\text { Affetuoso/Un } \\
\text { poco And. }\end{array}$ & aba \\
\hline Fulvia & Caro padre & Lá M & $4 / 4$ & And. Mod. & rondo \\
\hline Massimo & Nocchier che se figura & Sol M & $3 / 4$ & All Mod & rondo \\
\hline Onoria & Quanto mai fellice siete & Fá M & $6 / 8 ; 2 / 4$ & s.i.t./And & aba \\
\hline Valentiniano & So chi t'accese & Ré M & $4 / 4$ & $\begin{array}{l}\text { All Maestoso/ } \\
\text { Un poco And }\end{array}$ & aba \\
\hline Ezio e Fulvia & M'uccida, m'uccida & SibM & $4 / 4 ; 2 / 4$ & $\begin{array}{l}\text { And. Spiritoso/ } \\
\text { All }{ }^{\circ} \text { assai }\end{array}$ & cavatina \\
\hline
\end{tabular}

Ato 2

\begin{tabular}{|c|c|c|c|c|c|}
\hline Massimo & Va dal furor portata & Dó M & $4 / 4$ & All $^{\circ}$ Vivace & aba \\
\hline Ezio & Recagli quell'acciaro & Ré M & $4 / 4 ; 3 / 8$ & $\begin{array}{l}\text { All }{ }^{\circ} \text { Mod e } \\
\text { Sostenuto/And } \\
\text { Affet. }\end{array}$ & $\mathrm{aba}$ \\
\hline Fulvia & Tenneró per l'idol mio & SibM & $4 / 4 ; 3 / 8$ & $\begin{array}{l}\text { And. Affet./ } \\
\text { And. }\end{array}$ & $\mathrm{aba}$ \\
\hline Varo & Nasce al bosco in rozza & Lá M & $3 / 4 ; 2 / 4 /$ & $\begin{array}{l}\text { And. Vivace/ } \\
\text { And }^{\circ}\end{array}$ & aba \\
\hline Onoria & Fin che per te mi palpita & Mib M & $3 / 8$ & And. Moderato & $a(b) a$ \\
\hline Quarteto & Non trionfar & Sol M & $4 / 4 ; 3 / 4$ & All $^{\circ} /$ And $^{\circ}$ Mod & aba \\
\hline
\end{tabular}

Ato 3

\begin{tabular}{llllll}
\hline Ezio & Tutto il mio sangue & SolM & $4 / 4$ & Allegro & aba \\
\hline Valentiniano & Per tutto il timore & Sib M & $4 / 4 ; 3 / 4$ & n.d. /Andantino & aba \\
\hline Fulvia & Ah, non son io che parlo & Fá M & $6 / 8$ & Allegro & $\begin{array}{l}\text { dal } \\
\text { segno }\end{array}$ \\
\hline Coro Final & $\begin{array}{l}\text { Pela vita nel dubbio } \\
\text { camino }\end{array}$ & Sol M & $3 / 4$ & Allegro & a,a \\
\hline
\end{tabular}

Ao final, os esforços com Ezio apontam a tendência madura, com influências germânicas, de Jommelli, ainda que se associem aspectos típicos do Galante, em especial da opera seria de feitura italiana, fazendo coexistir na partitura elementos então tradicionais e novidades de estrutura e linguagem, resultando num trabalho com características de certo ecletismo. 


\section{Bibliografia}

BRAGA, Teophilo (1871), História do Theatro Portuguez: a baixa comédia e a ópera, seculo XVIII. Lisboa, Imprensa Portugueza..

BRITO, Manuel Carlos de (1982), Opera in Portugal in the Eighteenth Century. Cambridge, Cambridge Press.

ERSKINE, David (ed.) (1954), Augustus Herveys' Journal: beig the intimate account of the life of a capitan in the Royal Navy ashore and afloat, 1746-1759. Londres, William Kimber.

MARTINELLI, Gaetano (1772), Ezio, drama per musica da rapresentarsi nel real teatro dell'ajuda in occasione di festegiarsi il felicissimo giorno natalizio di sua reale maestá l'augustissima signora D. Marianna Vittoria, regina fidelíssima. Lisboa, Stamperia Real.

McCLYMONDS, Marita (1980), Niccoló Jommelli, the last years, 1769-1774. Michigan: UMI.

MONTEIRO, Nuno Gonçalo (2006), Dom José. Rio de Mouros, Circulo de Leitores, 2006.

ROBINSON, Michael (1972), Naples and Neapolitan Opera. Oxford, Clarendon Press.

SANTOS, Mariana Amélia Machado (org.) (1958-1968), Catálogo de Música Manuscrita 9 vols. Lisboa, Ministério da Educação Nacional/Biblioteca da Ajuda.

TWISS, R. (1775), Travels to Portugal and Spain in 1772 and 1773. London, Robinson.

WRAXHALL, Nathaniel (1815), Historical memoirs of my own time, Part the first, from 1772 to 1780. London, Cadell \& Davies, 1815.

\section{Fontes Manuscritas}

Ezio de Niccola Jommelli: manuscrito em três volumes pertencentes à Biblioteca da Ajuda, sob a cota 44-X-11/13 (154pp; 114pp; 62pp). 


\author{
Gil Miranda \\ Conservatory of Music - Oberlin College
}

\title{
EM BUSCA DO CONTEXTO \\ - MARIA AUGUSTA BARBOSA E EDUARDO LIBÓRIO
}

\section{Meio ambiente}

A primeira notícia de que dispomos acerca da carreira musical de Maria Augusta Barbosa consta da certidão comprovativa de ter feito, em Julho de 1930, com dezoito anos, e como aluna externa, os exames do $1 .^{\circ}$ ano de Acústica, e $3 .^{\circ}$ ano do curso geral de Piano, obtendo em ambos vinte valores (Arquivo do Min. da Ed. Nacional, Conservatório, Proc. ${ }^{\circ}$ 1562). Em Junho do ano seguinte, ainda como aluna externa, requeria matrícula cumulativa nas disciplinas de Acústica e História da Música (2. ${ }^{\circ}$ ano); Piano (4. $.^{\circ}, 5^{\circ}$ e $6 .^{\circ}$ anos do curso geral); e Harmonia (1. ${ }^{\circ}, 2^{\circ}$ e $3 .^{\circ}$ anos), declarando que fora leccionada nelas, respectivamente, por Maria Ana Gomes Pereira, Artur Fernandes Fão, e Mário Manique. E em Julho imediato apresentava-se a exame nas mesmas, obtendo a classificação máxima em todas, exceptuado um dezasseis em Harmonia (mesmo Arquivo, e processo).

No outono de 1931 vinha matricular-se, agora como aluna interna, nos cursos de Italiano (Virgínia Vitorino), superior de Piano (José Vianna da Motta), e superior de Composição (Antonio Eduardo da Costa Ferreira). E prestou provas finais de: $2 .^{\circ}$ ano de Italiano, em 1933, com 18 valores; $2 .^{\circ}$ ano superior de Composição, em 1934, com vinte valores; e 3. ${ }^{\circ}$ ano superior de Piano, em 1936, com dezanove valores (ibid).

O currículo da sua passagem pelo Conservatório omite necessariamente os anos de preparação que a precederam, deixando na sombra a idade em que terá iniciado os estudos musicais. Estudos decerto bem dirigidos, que, 
aliados a uma viva inteligência, lhe proporcionaram uma carreira brilhante no Conservatório.

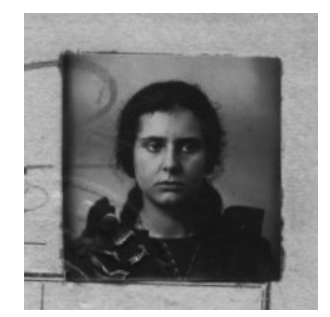

Figura 1 .

Diferentemente de outros estudantes que, por volta dos dez anos de idade, escolhiam o Conservatório em vez do liceu, Maria Augusta cursou o Conservatório, terminado o liceu, jovem adulta, entre os dezoito e os vinte o quatro anos (Figura 1). Com a sua inteligência, e meticulosa organização intelectual, não terá deixado de absorver tudo que a cercava no meio musical lisboeta. Os anos de 1932 a 1936 - contemporâneos da sua passagem pelo Conservatório - viram a publicação por Mário de Sampayo Ribeiro (1898-1966) dos quatro volumes iniciais das Achegas para a História da Música em Portugal - a primeira obra musicológica de fôlego dele. A importância e novidade do empreendimento não podia ter deixado de impressioná-la. Sampayo Ribeiro dava um passo consciente que o distanciava do trabalho dos seus antecessores, incluindo os dicionaristas Joaquim de Vasconcellos e Ernesto Vieira, e o enciclopédico Sousa Viterbo. Sem lhes negar a função meritória de salvar a música antiga do esquecimento total, esses autores, em regra, tinham-se dedicado a acumular dados biográficos e bibliográficos sobre músicos e música do passado, apoiando-se amplamente, para seus juizos, em fontes secundárias, e sem entrar no estudo das espécies musicais por eles referidas (Miranda 2011, 20, e notas 60, 63).

O projecto de S. Ribeiro reclamava-se de um intuito duplo. Em primeiro lugar, prometia abster-se de reeditar e compilar opiniões alheias. Em segundo lugar, propunha-se ultrapassar a corrente positivista reinante, e estudar as composições sob exame, o que envolveria por vezes ter de realizá-las, pondo-as em 
partitura, penetrar-lhes o sentido, interpretá-las, e avaliá-las (Ribeiro 1936, Prefácio, e 15-19). Do campo da historiografia estéril passava para o da interpretação e crítica musicológicas.

Maria Augusta viria a conhecer pessoalmente Sampayo Ribeiro e sua mulher Maria Luisa. O contacto com o casal terá intensificado a sua admiração por Sampayo Ribeiro, ao dar-se conta que o grande motor por detrás do desenvolvimento dele como musicólogo se entrelaçava na ambição de enobrecer-se perante Maria Luisa, vindo assim a merecê-la, a despeito da oposição veemente do pai dela ao casamento de ambos (Miranda 2011, 5).

Uma componente inquestionável da época em que Maria Augusta se formou e desenvolveu foi o espírito e convicção nacionalista. Os músicos portugueses das mais variadas orientações, incluindo políticas, interrogaram-se intensamente sobre as condições e requisitos de uma música nacional. As respostas teóricas a essa interrogação variaram (v. Miranda 2011, 7, e Miranda 1992, 81, 161-163), o mesmo acontecendo no campo da prática. Logo num dos seus primeiros escritos, S. Ribeiro enunciava o cerne do seu programa: "evocar as páginas de oiro da nossa história, e suscitar o amor do povo pelos seus herois' ...; “ " ensinar a bem-querer os nomes que se ilustraram nos demais campos, e nas letras e nas artes; e a amar e conhecer as obras que nos legaram, ou por que se imortalizaram”... (Ribeiro, 1934, 8). Entre outros músicos do passado, ele dedicava especial atenção aos polifonistas portugueses do Século xviı. Ao mesmo tempo, Manuel Joaquim (1894-1986) empregava doze anos da sua vida na decifração e edição do Cancioneiro Musical de Elvas. Por seu turno, Fernando Lopes Graça (1906-1995) recolhia, e inspirava-se na canção popular portuguesa. E Ivo Cruz (1901-1985) ia reunindo a sua biblioteca de raridades musicais, que viria a constituir, passados anos, a Colecção Ivo Cruz, na Biblioteca Nacional, integrando perto de duzentas espécies musicais de autores estrangeiros e portugueses, entre estes, Carlos Seixas, Domingos Bontempo, José Maurício, e o chamado Cancioneiro Musical da Biblioteca Nacional - um MS de nove cadernos in 8.vo de música vocal do Século xvi, incluindo polifonia religiosa e profana.

Um dos volumes de Seixas, e as peças profanas do Cancioneiro Musical da $\mathrm{BN}$, foram objecto de publicação moderna, respectivamente por Vasconcellos 1975; e Morais, 1986. 
Portanto, ao escolher o assunto da sua tese de doutoramento na Universidade de Köln - Vicentius Lusitanus: ein portugiesischer Komponist und Musiktheoristiker des16. Jabrhunderts, Maria Augusta estava perfeitamente integrada no ambiente intelectual português da sua época. ${ }^{123}$

\section{Uma herança de respeito}

Entre os que entusiasticamente labutaram no resurgimento da música nacional conta-se Eduardo Libório (1900-1946), que foi o antecessor de Maria Augusta na regência da cadeira de história da música no Conservatório Nacional, para a qual fora nomeado em Outubro de 1939 (Miranda 2010, 12, e nota 3). Tal nomeação incluía as disciplinas de acústica e história da música, as quais tinham estado sem titular desde Novembro de 1937, por ter atingido o limite de idade o padre Tomaz Borba (id., 10, nota 1). A posse de Libório durou escassos seis anos, datando de 1944 os primeiros ofícios do director do Conservatório Nacional relativos a faltas suas por motivo de doença. Em princípio de Fevereiro de 1945 abandonava a cátedra para tratamento no sanatório do Caramulo, não a retomando até à morte, a 2 de Março do ano seguinte (id., 14). Maria Augusta foi então escolhida para lhe suceder em acústica e história da música, em Outubro de 1946 (N. ${ }^{\circ} 4$ / Livro de Posses / 1946 [do Conservatório Nacional], p. 10 v. ; v. tb. Boletim do Conservatório Nacional / 1946-1947, p. 5 - "Corpo Docente").

Apesar da brevidade da sua passagem pelo Conservatório, Eduardo Libório deixou marca inconfundível nas áreas de história da música, e acústica.

123 Vicentius Lusitanus: ein portugiesischer Komponist und Musiktheoristiker des 16. Jahrbunderts. Maria Augusta Barbosa, Lissabon: Secretaria de Estado da Cultura. Direcção Geral do Património Cultural. 1977. XXVIII, 502 pp. 8 ill. facsimile. Existe, igualmente, versão portuguesa policopiada (s.l; s.n.), 1977. Para além da tese de doutoramento, a autora, seguindo aliás a prática de muitos profissionais nacionais altamente qualificados do seu tempo, dedicou-se exclusivamente à tarefa docente. Identificaram-se poucos escritos seus, e esses de carácter oficial, ou de circunstância, nomeadamente: a) "Algumas palavras no dia mundial da música. 1987", ocupando pp. 1-18 da publicação Dia Mundial da Música 1987: Conferências pela Oradora Oficial Prof. Doutora Maria Augusta Barbosa e "Contribuição de Elvas para a História da Música" pelo Revmo Cónego José Augusto Alegria. Elvas: Câmara Municipal, 1987, 347 pp.; e b) recensão na Revista Portuguesa de Musicologia, n. 3 (1993), p. 206, sob o título: "Gil Miranda: Jorge Croner de Vasconcellos - Vida e Obra Musical”. A propósito deste último, é de notar que, tendo-lhe submetido para crítica a versão inicial dos capítulos 2 e 5 da obra, ela me forneceu um exame tão pormenorizado, justo, e proficiente, que me serviu só por si de guia na revisão do resto do livro. 


\subsection{História da música}

Muito novo, como aluno da Faculdade de Letras e presidente da Associação Académica do Conservatório Nacional, organizara conferências e concertos de intercâmbio destinados a divulgar a música de tecla portuguesa dos séculos XVII e XVIII.

Em 1923 fundava, de parceria com Ivo Cruz, o movimento Renascimento Musical, dirigido por ele, e a que no ano seguinte se juntaria Mário de Sampayo Ribeiro. Entre outras actividades, promovia concertos históricos em que introduzia, junto do público contemporâneo, compositores portugueses inteiramente desconhecidos deste. O primeiro realizou-se em Lisboa, na Liga Naval, a 1 de Fevereiro de 1924.

O programa incluia: Tento em ré, do padre Manoel Rodrigues Coelho; Capricho (?), de José Antonio Carlos de Seixas; Tocata, de Francisco Xavier Baptista; "Andante" da Tocata em lá, de João de Sousa Carvalho; Sonata em Si bemol, a 4 mãos, de Joaquim Casimiro; e Fantasia Op. 14, de João Domingos Bontempo (Ribeiro 1924, 2, col $^{\mathrm{a}} 1$ e 2). Além de Libório, foram executantes: Ivo Cruz, Fernando Amado, e Evaristo de Campos Coelho. Outros concertos se seguiram incluindo mais compositores desconhecidos, como Policarpo Antonio da Silva, e João de Matos.

Entretanto, na Academia de Amadores de Música, fundava, de parceria com Lucila Moreira, uns Cursos de Estudos Musicais, onde regeu a primeira cadeira de música portuguesa, continuando aí então os seus concertos históricos. Em data não verificada, a convite do director do Conservatorio de Musica e Declamação de Madrid, deu aí uma conferência-concerto. E em 1936 deslocava-se à Alemanha, para um concerto na Emissora de Berlim.

Ao mesmo tempo, colaborava no programa de música de câmara da Emissora Nacional, para o qual organizou em 1942 uma série de onze concertos sob a rubrica Serões de Outono, cujas notas de programa da sua autoria integram o seu espólio presentemente na Biblioteca Nacional.

Paralelamente, exerceu crítica musical, pelo menos para o diário O Século, e foi colaborador permanente nas secções de crítica e musicologia da Revue Internationale de Musique, de Bruxelas (Miranda 2010, 11). 
Os relatos dos seus colegas e alunos são unânimes em recordar a sua aula como irradiando interesse e vida, incluindo visitas ao Museu de Arte Antiga, para, por exemplo, lhes mostrar as correspondências formais entre a fuga e um tapete de Arraiolos. Vale a pena citar uma passagem de artigo seu sobre o ensino da história da música:

"No momento presente, merecem tanto aprêço 'os compositors menores' como os que noutro tempo prendiam a atenção do historiador. Assim, para explicar as diferenças orgânicas, constitucionais, que se notam entre os géneros musicais da primeira metade do século xviII e os que se fixaram na Escola dos clássicos de Viena, não basta conhecer Bach e Haendel, Haydn, Mozart e Beethoven. É indispensável recorrer à obra, por vezes anónima, esquecida ou desprezada, dos que ficaram no período formativo ou de transição, e que não chegaram a representar perfeita expressão da época considerada."

"Colocadas em plano idêntico aos dos grandes monumentos dramáticos e sinfónicos dos séculos XviII e xix, ou dos da época da polifonia vocal a cappella, também as formas íntimas de música, reintegradas na sua função histórica, assumem hoje excepcional importância na literatura medieval e pre-clássica. A canção trovadoresca, as formas primitivas da música instrumental da 'Ars antiqua', o 'Cantus gemellus' inglês, o 'Rondo, a 'Balada' e o 'Madrigal' florentino, a canção franco-flamenga do século XIv, o 'Air de Cour' e as obras para guitarra, vihuela, e alaude do século XVI, são, por todos os títulos, essenciais para o estudo das formas da música anteriores ao nascimento da ópera, da Oratória e da Sinfonia” (Libório 1942, 2-3).

Porém, o seu interesse extendia-se aos compositores modernos. Entre 1933 e 1939 Libório participou nas sessões de divulgação musical promovidas pela cantora Emma Romero Santos Fonseca e seu marido Luís da Câmara Reys, na residência de ambos em Lisboa. Aí apresentou, em três conferências, a música do uruguaio Afonso Broqua, do hindu Kaiskhosru Sorabij, e dos franceses Georges Migot, André Caplet, Charles Koechlin, e Maurice Ravel (Miranda 2010, 19-20, nota 13). 
Amplamente informado, Libório foi acima de tudo um divulgador. No respeitante à história da música portuguesa, valeu-se amiúde da investigação do seu contemporâneo, Mário de Sampayo Ribeiro.

\subsection{Teoria acústica}

Antes de prosseguir na apreciação do ensino de Libório, convém relembrar a evolução dos estudos acústicos. Se, por um lado, durante séculos, a música foi encarada sob os ângulos metafísico e matemático, por outro lado, o estudo do som em si confinou-se ao domínio da física acústica, só a pouco e pouco sendo reconhecida a contribuição dos campos da fisiologia e da psicologia (Riemann 1882, 3). E mesmo então, como adiante se verá, a tendência de privilegiar a acústica tem resistido tenazmente.

Três períodos principais avultam no estudo físico do som: 1) desde os gregos até Jean Philippe Rameau: 2) depois de Rameau; 3) desde o uso de instrumentos de precisão na análise acústica. O primeiro é marcado pelo uso do monocórdio que consistia de uma corda vibrante, cuja extensão variável permitia estudar a relação entre extensão e a frequência das vibrações obtidas; o segundo é marcado pela descoberta dos sons harmónicos parciais; o terceiro pela utilização de instrumentos electrónicos na medição dos elementos sonoros componentes.

No primeiro destaca-se a figura de Gioseffo Zarlino (1517 ?- 1590), que terá sido o primeiro a expressamente legitimar a terceira menor, e o acorde menor, ao dizer: "Ma perche gli estremi della Quinta sono invariabili,...peró gli estremi delle Terze si pongono differenti tra essa Quinta. Non dico però differenti di proportione; ma dico differenti di luogo: percioche ... quando si pone la Terza maggiore nella parte grave, l'Harmonia si fà allegra; \& quando si pone nella parte acuta si fà mesta. .... Se dunque noi vorremo variar l' harmonia ... è dibisogno, che noi poniamo le Terze differenti in questa manera; che havendo prima posto la Terza maggiore, che facia la mediatione Harmonica, potremo dipoi porre la minore, che farà la divisone Arithmetica" [Porque enquanto os extremos da Quinta são inalteráveis, porém os das Terceiras podem variar dentro da Quinta. E não digo variar de proporção, mas de posição ... Quando se põe a Terceira maior na posição inferior, a Harmonia resulta alegre; e quando 
se põe na posição superior resulta triste ... Portanto, se quizermos variar a harmonia, devemos pôr as Terceiras diferentes deste modo: que tendo primeiro posto a Terceira maior, como mediante Harmónica, ponhamos depois a menor, que constituirá a divisão Aritmética] (Zarlino 1561, III, Cap. 31, 181-2).

Na teoria musical do século xvi designava-se harmónica (ou geométrica) a divisão do monocórdio em fracções de denominador variável: 1, 1/2, 1/3, 1/4, 1/5, 1/6; e aritmética a divisão em fracções de denominador constante: 6/6, $5 / 6,4 / 6,3 / 6,2 / 6,1 / 6$. A primeira produzia secções de extensão variável, a segunda secções de extensão constante. O interesse teórico (e prático) destas divisões residia na circunstância de a primeira dar origem ao acorde maior, a segunda ao acorde menor:

\begin{tabular}{|c|c|c|c|c|c|c|c|}
\hline $1 / 1$ & & & $1 / 2$ & $1 / 3$ & $1 / 4$ & $1 / 5$ & $1 / 6$ \\
\hline DÓ & & & dó & sol & dó’ & mi' & sol' \\
\hline \multicolumn{8}{|c|}{ Divisão aritmética } \\
\hline $6 / 6$ & $5 / 6$ & $4 / 6$ & $3 / 6$ & $2 / 6$ & & & $1 / 6$ \\
\hline DÓ & MI bemol & SOL & dó & sol & & & sol' \\
\hline
\end{tabular}

Figura 2 - (Harvard 1958, 12; Harvard 2003, 56)

Conquanto os ensinamentos de Zarlino tenham tido seguidores imediatos em Itália, e sido traduzidos ou adaptados em França, na Flandres, e na Alemanha, cedo foram esquecidos e obliterados pela prática do baixo cifrado, e das tablaturas, espécie de estenografias musicais, em que o signo tendia a distrair do conteúdo significado (Grove 2001, XXVII, 753; Riemann 1882, 7 ss.).

Passado mais de século e meio, Jean-Philippe Rameau (1683-1764), no seu Traité de l'harmonie reduite à ses principes naturels (1722) chamou de novo a atenção para a realidade musical velada pelas cifras, abrindo novo capítulo nos conhecimentos da acústica musical. A ele se deve a emancipação da fundamental do acorde, da tirania do baixo todo poderoso, o conceito da inversão dos acordes perfeitos, e o da série dos sons harmónicos superiores, isto é, a descoberta que uma corda vibrante, produz naturalmente, sobreposta ao som fundamental, a série que resultaria da sua efectiva divisão harmónica, 
embora de intensidade menor que a do som fundamental, e que se vai desvanecendo à medida que mais se distancie daquele.

À semelhança da divisão harmónica, os primeiros seis sons da série produzem o acorde perfeito maior. Mas haveria maneira de encontrar acusticamente base para o acorde menor? Quando Rameau verificou que uma corda vibrante desencadeava a vibração simpática de outra de extensão dupla da primeira, admitiu a hipótese da existência de uma série inferior espelhando a dos harmónicos superiores, e que produziria o acorde perfeito menor. Porém, o físico Jean-Baptiste D’Alembert (1717-1783) dissuadiu-o, ao fazer-lhe notar que a corda posta a vibrar em simpatia "não vibrava em toda a sua extensão", reproduzindo apenas, sem o alterar, o som que lhe era fornecido pela outra (Riemann 1882, 12).

As descobertas de Rameau foram o ponto de partida para novos desenvolvimentos da ciência acústica. D’Alembert, (nos seus Éléments de musique théorique et pratique, suivant des principes de M. Rameau), e o violinista Tartini (1692-1770) notaram que a série dos harmónicos não parava no som 6, continuando indefinidamente, com intensidade decrescente (Riemann 1882, 15-17):

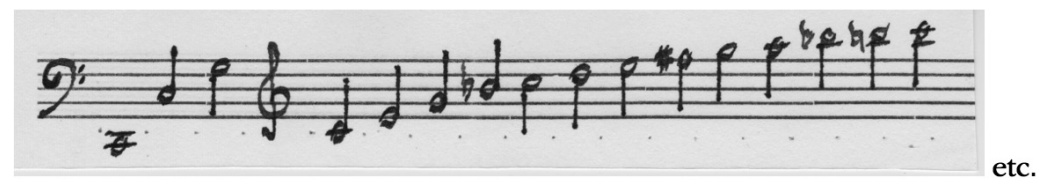

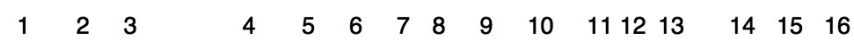

Figura $3-\left(^{*}\right)$ assinala sons mais baixos do que os da escala temperada.

Tartini, e, simultaneamente, o organista alemão Sorge descobriram o fenómeno da existência de sons criados pelo ouvido, i. e. independentes da produção por uma fonte sonora. Pertencem a esse número os sons diferenciais, resultantes da combinação de dois sons da série harmónica. Assim, tocando num violino a diade sol e mi' (sons 3 e 5 da série) o ouvido percebe a presença também do som 2 (dó), cuja frequência é sensivelmente igual à diferença entre as dos sons 5 e 3 e que, como é sabido, está fora do âmbito do instrumento (Jeans 1961, 237). E, surpreendentemente, o grande físico Hermann 
Helmholtz (1821-1892) ao estudar os sons diferenciais, verificou que, contra a opinião de muitos, eles tinham existência objectiva, pois pôde captá-los e medi-los experimentalmente (Jeans 1961, 238-240). O trabalho de Helmholtz caracterizou-se pela sua extensão e rigor científico, cobrindo não só a acústica mas a fisiologia da percepção dos sons. Quanto ao acorde menor, ele viu a sua fundamentação nos n.o s 10, 12, e 15 da série harmonica (Fig. 3).

Com Helmholtz, o centro do estudo científico do som deslocou-se para a Alemanha, onde recebeu, pelo menos de início, a influência do dualismo de Hegel, bem marcada na obra de Moritz Hauptmann (1792-1868), Arthur von Oettingen (1836-1920), e Hugo Riemann (1849-1919).

Hauptmann distinguiu-se, principalmente, pela especulação metafísica sobre as estruturas dialécticas em música, abrindo caminho para as especulações acústicas de Oettinger e Riemann (Harrison 1994, 232).

Oettingen preocupou-se especialmente com encontrar um fundamento mais satisfatório para o acorde menor do que o de Helmholtz. Aplicando a lógica dualista, estabeleceu a hipótese seguinte:

1) Dois sons parciais [da série harmónica] possuem em comum a mesma fundamental.

2) Dois sons fundamentais possuem em comum um mesmo som parcial.

A primeira relação ele qualificou como "tónica"; a segunda como "fónica" (Harrison 1994, 247). A fim de provar a sua hipótese, Oettinger procurou aplicá-la praticamente. Tomem-se os sons 3 e 5 da série harmónica cuja fundamental comum é DÓ, e considerem-se agora eles mesmos como sons fundamentais: verifica-se que possuem um som parcial comum - o "fónico" b" que pertence ao acorde menor de mi:

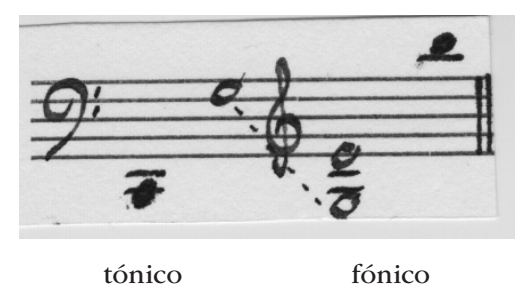

Figura 4. 
Note-se a simetria dos intervalos entre DÓ e sol, e b" e mi'. Para Oettinger, estava-se perante uma relação de oposição simétrica, segundo a qual o primeiro acorde (maior), era baseado no som tónico Dó, o segundo (mi menor) no som fónico Si.

Veio Riemann, e estendeu o princípio dualista à própria base acústica do edifício sonoro, retomando a hipótese da existência de harmónicos inferiores entrevista por Rameau (ver acima). Para tal, recorreu à passagem de Zarlino atrás citada, em que ele distinguia as divisões harmónica e aritmética do monocórdio. Quanto a esta, Riemann defendeu, contra a evidência histórica, que "Por divisão 'aritmética' [Zarlino significara] o som dos múltiplos de uma pequena secção do monocórdio, $[x]$ 1:2:3:4:5:6" (sublinhado de Riemann $1882,7)$, dando lugar à série, geradora do acorde menor:

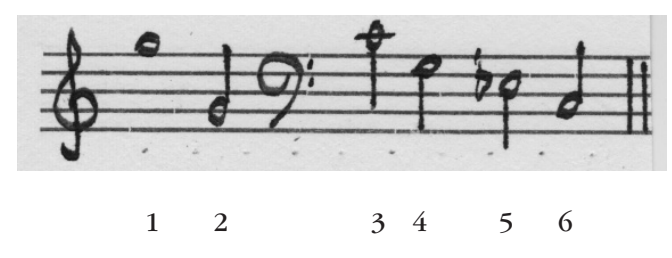

Figura 5 - Divisão aritmética segundo Riemann.

Depois, prolongando essa ideia de multiplicação de um segmento do mocórdio, erradamente atribuida a Zarlino, completou a série de harmónicos inferiores, representando o inverso exacto da série de Figura 3:

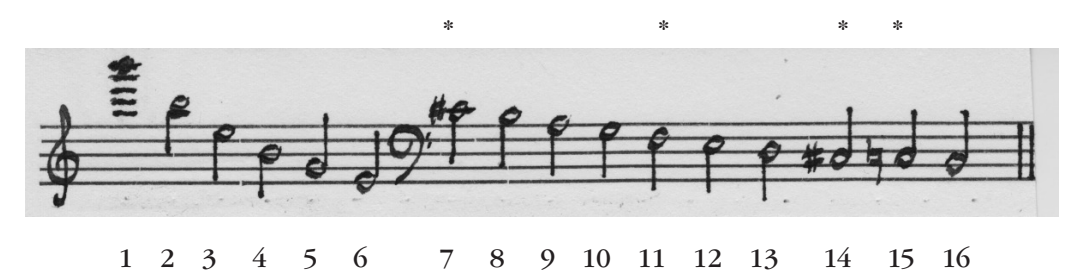

Figura $6-\left(^{*}\right)$ assinala sons ligeiramente mais altos do que na escala temperada.

Note-se que, a pesar da defesa ardente da necessidade da série dos harmónicos inferiores, como fundamento do modo menor, por vezes, Riemann revelou insegurança acerca da sua existência real: 
“Com efeito, é provável que cada som produza sempre não só uma série harmónicos superiores, como também de harmónicos inferiores, de amplitude decrescente na razão inversa da sua distância, e mais difíceis de ouvir e separar, na massa de sons na nossa mente, do que os harmónicos superiores. Tenho coligido diligentemente toda a informação possível sobre este tópico e, tanto quanto pode observar-se, não encontro nada que contrarie esta hipótese....

E adiante:

"Independentemente do que se pense acerca da minha opinião, uma coisa é certa: Os acordes maior e menor são, do ponto de vista matemático e acústico, polos opostos entre si” (sublinhado de Riemann cit., 20).

Com efeito, para Riemann o acorde menor era a inversão do acorde maior: naquele, também a uma $3 .^{a}$ maior se seguia uma $3 .^{a}$ menor, mas contando de cima para baixo. Consequentemente, no acorde menor em estado fundamental era a quinta, não o baixo, que ocupava o lugar da fundamental. Mais uma vez, ele se serviu de uma leitura ahistórica da passagem de Zarlino (acima) para corroborar a sua opinião, ao afirmar que

"segundo Zarlino, o acorde menor era matematicamente o oposto exacto do acorde maior" (sublinhado de Riemann cit., 7).

Deve notar-se que, paralelamente à via acústica, Riemann permaneceu aberto à hipótese de justificação puramente psicológica dos modos maior e menor. Assim, após ter procurado provar a génese do acorde menor através da resonância inferior, ele afirma:

"Que nós possamos imaginar um som como pertencendo a um acorde menor, tão facilmente como a um acorde maior, quando nem um nem outro estejam [a ser tocados], isso constitui um dado científico sobre o qual podemos construir com tanta segurança como sobre fenómenos acústicos. Uma vez que tenhamos reconhecido isso, torna-se irrelevante que o acorde menor possa ou não basear-se em dados acústicos" (Riemann cit., 27-28). 
Riemann foi extremamente prolífico, exercendo considerável influência nos teóricos que lhe sucederam, uns seguindo-o fielmente, outros adpatando ou reformando as suas posições (Harrison 1994, 293-320). A sua interpretação do acorde menor, considerando a quinta como fundamental do acorde, era puramente intelectual, e desmentida pela experiência dos músicos (incluindo Zarlino!), para quem maior e menor eram duas faces da mesma medalha, e foi logo abandonada pelo seu discípulo, Max Reger (Harrison cit., 296-297).

Também a existência da série de harmónicos inferiores foi debatida. Em 1931, ainda o Prof. do Conservatório Nacional, Luiz de Freitas Branco a dava como certa, e comprovada pela verificação (já antes feita por Rameau), que uma corda vibrante desencadeava a vibração simpática de outra de extensão dupla da primeira. Argumentava F. Branco que, pondo "fragmentos de papel, dobrádos e colocados" sobre a corda "de um piano de cauda" cuja extensão fosse dupla de uma corda percutida, eles caiam ao percutir-se a corda mais curta, "levantados os abafadores". Coerentemente, ele oferecia no seu texto ambas as séries de harmónicos, ascendente e descendente, geradoras respectivamente, do acorde maior e menor (F. Branco 1931, 11-12; 65).

Simplesmente, a mesma experiência realizada com maior rigor científico viria a revelar que os fragmentos de papel dobrados cairiam todos menos um - o colocado exactamente no centro da corda de extensão dupla da primeira, porque a vibração por simpatia fá-la vibrar em duas metades, com um nó no centro, que permanece imóvel (Jeans 1961, 74-75). D’ Alembert já disso avisara Rameau, o que infirma a hipótese aventada por Riemann, da vibração por múltiplos da extensão inicial, fazendo cair por terra, definitivamente, a teoria da série dos harmónicos inferiores.

\subsection{As lições de Libório}

Por morte de Libório, o seu amigo, o compositor Jorge Croner de Vasconcellos, recolheu os apontamentos das lições de harmonia daquele; e por morte deste, finalmente, vieram a integrar, por doação, o espólio de Eduardo Libório presentemente na Biblioteca Nacional. Contêm os apontamentos cerca de 31 folhas, sendo dez dedicadas a uma apresentação sucinta da evolução da teoria acústica, cobrindo uma breve introdução à teoria no século xıv, seguida 
de Zarlino; Rameau; Tartini; Auguste Barbereau (1799-1879); Camile Durutte (1803-1881); Moritz Hauptmann; Hermann Helmholtz; Arthur von Oettingen; e Hugo Riemann.

Durando o curso dois semestres apenas, é notável a atenção prestada à teoria acústica, tendo Libório sentido também a necessidade de prover uma nota biográfica sobre cada autor citado. Essa atenção justificava-se: não só focava um problema essencial da música ocidental - a fundamentação teórica do modo menor - como permitia tratar (embora obliquamente) da vexata questio dos harmónicos inferiores.

Depois da exposição acima sobre a evolução da teoria acústica, bastará agora uma breve resenha sobre os apontamentos de Libório.

No tocante a Zarlino, Libório parece ter-se atido à interpretação de Riemann do texto das Istitutioni Harmoniche, talvez por não ter acesso ao texto original. Só assim se compreende que tenha atribuido ao italiano a defesa da ressonância inferior, de todo ausente daquela obra.

Mais interessante é o ter-se debruçado sobre dois teóricos franceses pouco lembrados - Barbereau e o seu continuador Durutte. A passagem seguinte sobre Durutte explica o interesse de Libório na sua obra:

"Durutte mostra que a série de harmónicos é insuficiente para a génese da nossa escala, e afirma a necessidade duma base de construção lógica para o sistema musical moderno."

Embora Libório acredite no dualismo da ressonância superior e inferior, não parece ter sustentado a existência da série de sons harmónicos inferiores. Por um lado, não a inclui na sua exposição, por outro lado, trata Riemann de forma muito abreviada. Pelo contrário, adopta as ideias de von Oettinger sobre a génese dos acordes maior e menor, traduzindo-as no diagrama da Figura 7. Acerca de von Oettinger afirma:

"Muito mais importante para a formação da moderna teoria da harmonia foram os estudos do físico russo Arthur von Oettingen.... [que propõe] uma explicação lógica do fenómeno harmónico, confirmada pelas investigações posteriores e que constitui o desenvolvimento das antigas ideias de Tartini relativas ao terceiro som." 


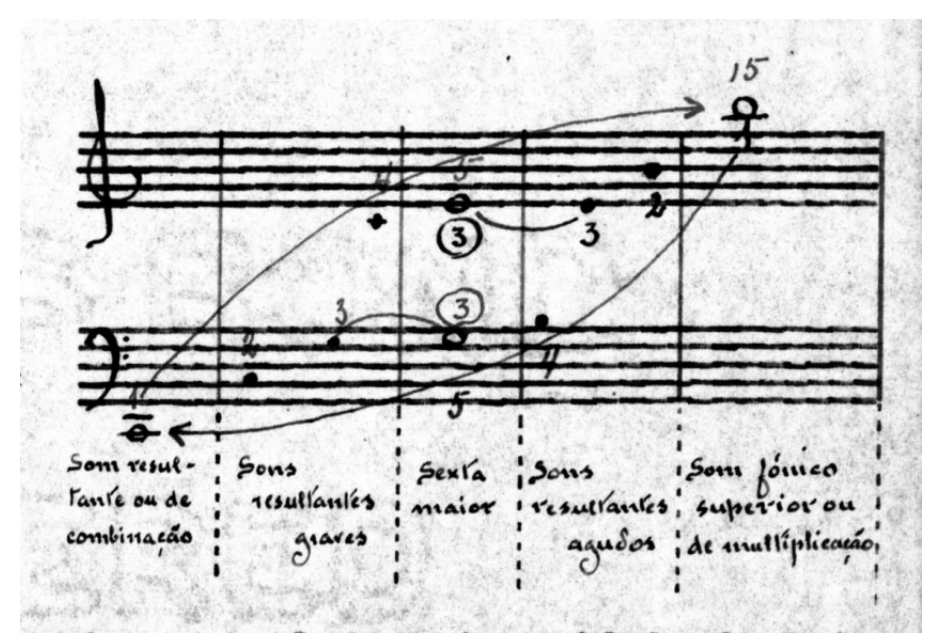

Figura 7 - Dedução dos acordes maior e menor.

E recapitula:

"Von Oettingen chama som de combinação ao som resultante ao Dó grave que serve de prima à resssonância maior, e som de multiplicação ao Si agudo (resultante da multiplicação dos dois harmónicos 3 e 5 um pelo outro) som que serve de prima à ressonãncia menor, e que von Oettingen também denomina som fónico superior. A perfeita simetria das duas ressonâncias torna-se assim evidente."

\section{Perspectiva e paralelo}

Eduardo Libório era um estudioso entusiasta: no tempo em que a maioria das casas em Lisboa não era aquecida - e ele era friorento - inventara um sistema de águas quentes que lhe permitia estudar na banheira, com os livros assentes sobre uma prancheta móvel. Porém, foi acima de tudo um músico prático, um divulgador de música e de ideias novas para os seus contemporâneos. A investigação científica demorada não parece ter sido o seu chamamento. Era também um poeta com o hábito de ilustrar os seu próprios poemas (Libório 2010). As suas lições de harmonia são profusamente ilustradas com diagramas coloridos, como o da Figura 8. 
Por seu lado, Maria Augusta Barbosa tinha o estofo de investigadora paciente. Embora apenas doze anos mais nova do que Libório, pertenceu já a uma geração para quem a senha era a busca documentada e rigorosa. Dotada para a investigação científica, viveu a maior parte da sua carreira guiando no Conservatório músicos práticos sem ambições académicas. O seu horário (1948-49) andou pelas doze horas semanais (o dos seus colegas de composição era de dezoito).

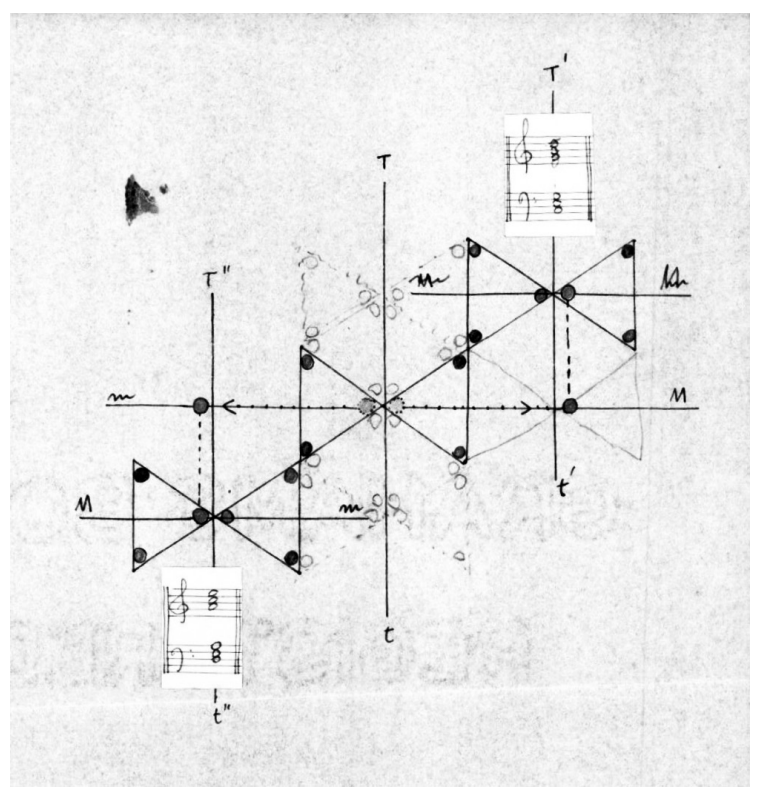

Figura 8 - Outra dedução dos acordes maior e menor

Conquanto a sua disciplina fosse Acústica e História da Música, não consegui registo da maneira como abordava a primeira. Em história da música, segundo os seus alunos, tinha um ponto de vista enriquecedor, convidando os alunos a encontrar ligações, por vezes inesperadas, com a literatura, a filosofia, as outras artes, e mesmo outras culturas. Não contente com os limites do programa official, ofereceu durante anos um curso livre aos sábados, em sua casa, àqueles estudantes que desejassem aprofundar os seus conhecimentos. E quando a Universidade de Coimbra criou na Faculdade de Letras, em 1986, um mestrado em ciências musicais, ela lançou-se de corpo e alma no novo empreendimento, que dirigiu durante anos. Levantava-se cedíssimo, tomava um taxi, de Paço D’Arcos, onde vivia, para a estação de Santa Apolónia a fim 
de apanhar o rápido para Coimbra. Fazia-o por inteiro amor à arte, pois apenas aceitava ajudas de custo para as despesas de transporte.

A música e a investigação tornaram-se-lhe, não em modo de vida, mas na própria vida. Quando um dia, de passagem por Lisboa, compareceu na cerimónia de registo do nascimento de uma afilhada sua, filha de um antigo aluno, e o oficiante lhe indagou acerca da sua residência, olhando em volta disse-nos, jocosamente - "as bibliotecas de todo o mundo". Descontando uma parte de ingénuo orgulho, havia naquela resposta uma grande dose de verdade.

\section{Bibliografia citada}

F. Branco 1931 - Elementos de Sciências Musicais por Luiz de Freitas Branco, Prof. do Curso Superior de Composição, do Conservatório de Lisboa, Vogal do Conselho Superior de Instrução Pública. Obra aprovada para o Ensino Oficial, Diário do Governo de 4 de Fevereiro de 1931. 1. ${ }^{\circ}$ Volume / Acústica. Edição do autor. Leipzig, Pp. 72.

Grove 2001 - The New Grove, Dictionary of Music and Musicians, 2.nd ed, Edited by Stanley Sadie, 29 vols.

Harrison 1994 - Harmonic Function in Chromatic Music - A Renewed Dualistic Theory and an Account of its Precedents, Daniel Harrison. Chicago and London, The University of Chicago Press, 1994. Pp. 337.

Harvard 1958 - Harvard Dictionary of Music, by Wili Apel. Cambridge, Massachusetts, Harvard University Press, 1958. Pp. 831.

Harvard 2003 - The Harvard Dictionary of Music, $4^{\text {th }}$ ed. Edited by Don Michael Randal, Cambridge, MA, and London, England, The Bellknap Press of Harvard Univ., 2003. Pp. 978.

Jeans 1961 - Science and Music, Sir James Jeans, Cambridge at the Univ. Press, 1961 Pp. 258.

Libório 1942 - "O Ensino da História da Música em Portugal", Separata da Arte Musical, Março de 1942. Lisboa, Imprensa Ideal. Pp. 7.

Libório 2010 - Eduardo Libório, Poesias, Desenhos e Correspondência - Prefácio, introdução, organização e notas de Gil Miranda, "Colecção arte e artistas" Lisboa, INCM 2010. Pp. 239.

Miranda 1992 - Jorge Croner de Vasconcellos (1910-1974) - Vida e Obra Musical, Gil Miranda Lisboa, Musicoteca,1992. Pp. 276.

Miranda 2010 - Gil Miranda Ed. Eduardo Libório, Poesias, Desenhos e Correspondência (acima).

Miranda 2011 - Relembrando Mário de Sampayo Ribeiro, por Gil Miranda, Lisboa, AvA Musical Editions, 2010. Pp. 47.

Morais 1986 - Vilancetes, Cantigas e Romances do Século XVI, por Manuel Morais, ed. Transcrição e Estudo de... Lisboa, Fundação C. Gulbenkian - Serviço de Música, "Col. Portugaliae Musica", Vol. 47, Pp. CCXVII +113. 
Ribeiro 1924 - Republica, 2/II/1924, "1. ${ }^{\circ}$ Concerto histórico na Liga Naval", Crítica a uma conferência/concerto ... M. de Sampayo Ribeiro sob pseudónimo "Ego".

Ribeiro 1934 - "Luisa Todi", Conferência [por Sampayo Ribeiro] realizada ao ar livre, na rua Luisa Todi, em Lisboa, na tarde do dia 8 de Julho de... Separata de Anais das Bibliotecas e Arquivo Municipais, Ano IV, n. 12 (Abril a Junho de 1934).

Ribeiro 1936 - A Música em Portugal nos Séculos XVIII e XIX (Bosquejo de História Crítica), N. ${ }^{\circ}$ III de Achegas para a História da Música em Portugal, esparata da Revista HISTÓRIA série a), Lisboa 1936. Pp.145 + Erratas.

Riemann 1882 - The Nature of Harmony, by Hugo Riemann, of Hamburg (A conference given at the Hamburg Conservatory of Music, February $\left.4^{\text {th }}, 1882\right)$, translated by John Comfort Fillmore. Philadelphia, PA, Theodore Presser, 1887. Pp. 32.

Vasconcellos 1975 - Carlos Seixas, Tocatas e Minuetes, - Jorge Croner de Vasconcellos e Armando José Fernandes, Revisão e Realização de... Lisboa, Biblioteca Nacional, 1975. Pp. $117+$ Índice.

Zarlino 1561 - Gioseffo Zarlino, Le Istitutioni Harmoniche, Venezia 1561. Saggi introdutivi di/Introductory studies by Iain Fenlon e Paolo Da Coi. Varianti dell'edizione del 1589 e indice a cura di/Variants of the 1589 edition and index by Paolo Da Coi. Roma, "Bibliotheca Musica Bononiensis" Sezione II n. ${ }^{\circ}$ 39, Arnaldo Forni Editore. 1999. Pp. $101+347$ pp. (facsimile).

\section{Agradecimentos}

É com prazer que consigno aqui a minha gratidão pelo concurso recebido de Helena Celestino da Costa que me facilitou os contactos em Lisboa; Dr. ${ }^{\text {a }}$ Luisa Marques, da Escola Superior de Teatro e Cinema, pelo auto de posse da Prof. ${ }^{a}$ Maria Augusta Barbosa, e o Boletim do Conservatório Nacional; Dr. ${ }^{a}$ Françoise Le Cunff, do Arquivo do Ministério da Educação Nacional, pelos dados sobre a carreira escolar da mesma Prof. ${ }^{a}$, e horários dos docentes; Dr. ${ }^{a}$ Sílvia Sequeira, do Centro de Estudos Musicológicos da Biblioteca Nacional, pelos apontamentos de Eduardo Libório; o meu colega Brian Alegant, do Oberlin Conservatory of Music, pela indicação do excelente trabalho de Daniel Harrison contendo uma história da Teoria Dualista; os discípulos da Prof. a Maria Augusta, Armando Santiago e Janine Hilton de Moura, pelo testemunho vivo acerca do ensino dela recebido; o Dr. José Maria Cardoso, e Dr. ${ }^{a}$ Helena Quaresma da Biblioteca da Faculdade de Letras da Universidade de Coimbra, que me forneceram os dados da conferência da Prof. a M. Augusta Barbosa referida na nota 123. 
André Granjo

Universidade de Coimbra

\section{O PROJECTO DE ENCOMENDAS DE MÚSICA \\ PARA BANDA DA S.E.C. DE 1977 A 1983: CONTEXTUALIZAÇÃO E OBSERVAÇÕES INICIAIS}

\section{Introdução}

O presente texto pretende ser uma exposição sucinta sobre o trabalho de investigação que desenvolvo com vista à obtenção do Doutoramento em Letras, na especialidade de Ciências Musicais Históricas, na Faculdade de Letras da Universidade de Coimbra. Esta investigação centra-se no projecto de encomenda de obras originais para Bandas Amadoras Comunitárias, vulgarmente conhecidas como "Bandas Filarmónicas", que foi desenvolvido pela Secretaria de Estado da Cultura (S.E.C.) e que pretendeu dotar as Bandas Amadoras Comunitárias de um repertório básico de qualidade mas cuja escrita estivesse ao alcance das capacidades técnicas dos instrumentistas amadores. Este projecto, que teve início, tanto quanto é possível precisar dada a falta de documentação oficial ${ }^{124}$, no início de 1977 vindo a terminar em 1983, foi enquadrado numa política mais vasta de acção sobre as Bandas Amadoras e nasceu também de anseios das próprias Bandas e de alguns dirigentes políticos e associativos que podemos identificar desde finais da década de 1960. Traçarei um retrato histórico e social das Bandas Amadoras Comunitárias no

\footnotetext{
124 Todo o arquivo documental da antiga Divisão de Música da S.E.C., nomeadamente do período entre 1975 e 1985, encontra-se extraviado. Foi entretanto posta a hipótese de que possa ter sido enviado para o arquivo do Pendão, hipótese esta que, devido às transferências de espólios arquivísticos que se têm vindo a processar entre os diferentes serviços da Direcção-Geral de Arquivos, ainda não foi possível confirmar.
} 
nosso país que visa contextualizar o objectivo educativo, social e artístico deste projecto de encomendas naquilo que era a realidade das bandas amadoras e terminarei descrevendo sumariamente as obras originais produzidas para o projecto no que diz respeito à sua forma geral e instrumentação, mencionando ainda alguns detalhes importantes quanto à génese de cada obra e quanto a problemas editoriais e técnicos que cada uma apresenta.

\section{A Banda Amadora em Portugal até à Revolução Democrática}

Com maior ou menor controvérsia, podemos afirmar que as Bandas Amadoras Comunitárias existem no nosso país desde a primeira metade do séc. XIX, sendo consideradas, ao longo de todo este tempo, uma das mais disseminadas formas de prática musical de conjunto. Será porventura entre as décadas de 1910 e 1940 que as Bandas Amadoras Comunitárias conhecerão um dos períodos mais activos e florescentes. A existência de diversos periódicos musicais dedicados à edição de partituras para banda, os diversos artigos sobre a importância das Bandas Amadoras Comunitárias e sua actividade presentes na revista Arte Musical ao longo da década de 1930, a plena inclusão da família de saxofones em praticamente todas as Bandas Amadoras Comunitárias portuguesas, os exemplos da instrumentação usada em milhares de partituras deste período presentes nos arquivos das Bandas, as descrições e preocupações expressas por Pedro de Freitas na sua "História da Música Popular em Portugal”, servem de base sólida para a constatação de que, de facto, este foi um período muito próspero de actividade das Bandas. O período pós Segunda Guerra Mundial, com todos os problemas económicos, sociais e políticos que atingiram o nosso país, será marcado por uma destruição progressiva das Bandas e um empobrecimento também progressivo da qualidade e quantidade do seu repertório.

Se tivermos em conta as sucessivas vagas de emigração, sobretudo de jovens adultos, e mais tarde o recrutamento para as diferentes frentes da Guerra Colonial e ainda a concorrência que pequenos grupos instrumentais 
de música ligeira, popularmente conhecidos como Jazzes ${ }^{125}$, fazem quer em termos de espaço performativo quer em termos de captação de instrumentistas, não nos é difícil perceber o estado de degradação e pobreza a que esta prática musical chega no início da década de 1970. Brucher (Brucher: 131-132) menciona vários exemplos de bandas na região da Bairrada que sofreram grandes reduções nos seus efectivos levando algumas à suspensão da actividade ou à extinção. A fim de melhor percebermos este efeito, atente-se no exemplo da Banda Filarmónica da Mamarrosa, freguesia do concelho de Oliveira do Bairro, fundada em 1916, então com o nome de "Banda Escolar da Mamarrosa”, pelo professor primário Jaime de Oliveira Pinto de Sousa. Nesta sequência fotográfica está bem patente, primeiro, o crescimento que a banda sustentou desde a sua fundação até ao final da década de 1920 e depois a sua degradação logo a partir de meados da década de 1950.

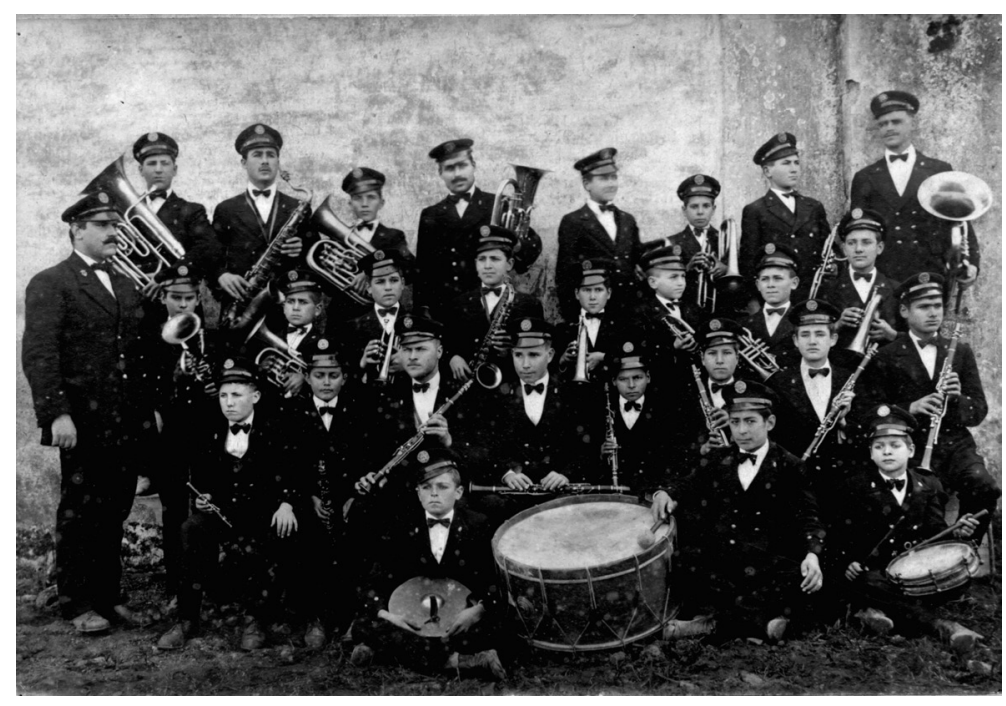

Ilustração 1 - "Banda Escolar da Mamarrosa", ca. 1918. Note-se a constituição da banda com 27 elementos e com uma variedade etária que engloba crianças, jovens e adultos.

125 Freitas, 1946: 531 


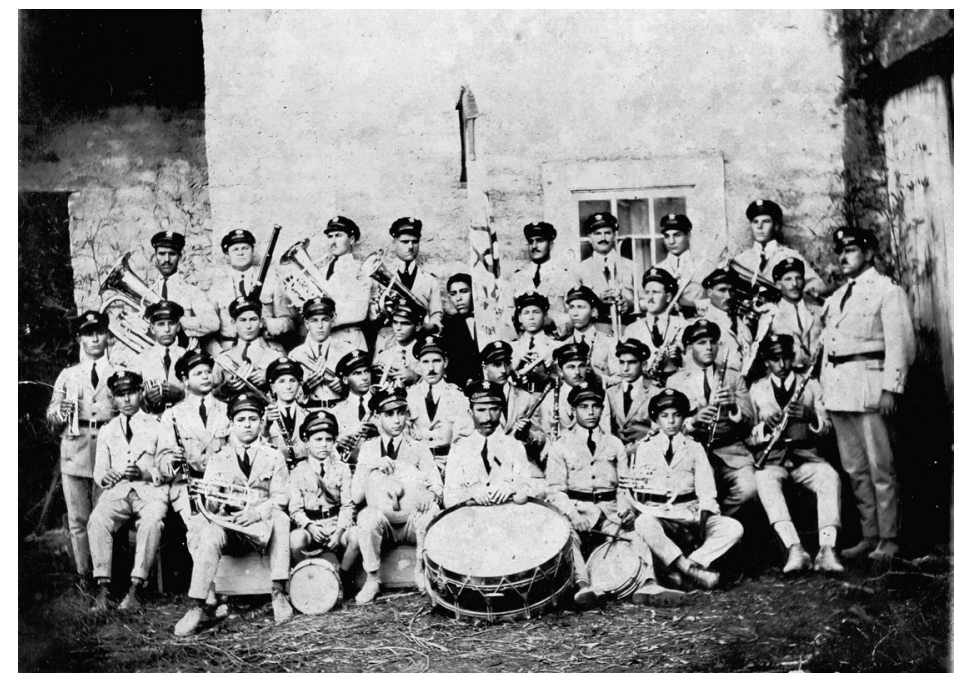

Ilustração 2 - "Banda Escolar da Mamarrosa", ca. 1928. Note-se a constituição da banda com 34 elementos, com uma grande variedade instrumental e com uma variedade etária que engloba crianças, jovens e adultos.

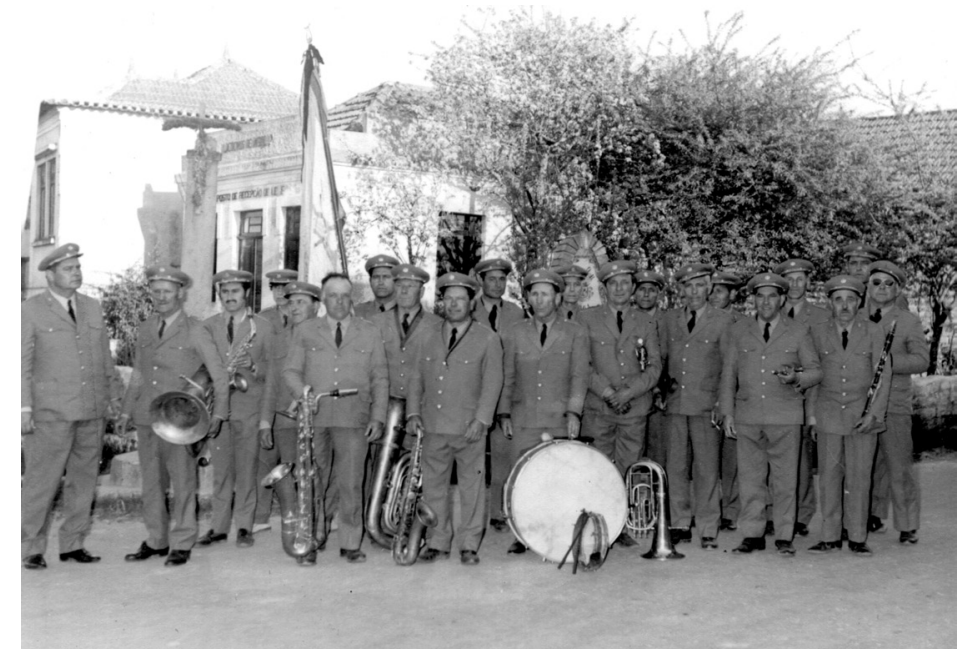

Ilustração 3 - "Banda Filarmónica da Mamarrosa”, em 1956. Note-se a constituição da banda com 19 elementos e com uma total ausência de crianças e jovens. 
A quantificação do número exacto de bandas existentes em Portugal num determinado período nunca foi tarefa fácil e nem nos dias de hoje essa contabilização é rigorosa. Existem no entanto algumas fontes bibliográficas que nos podem pelo menos ajudar a quantificar este processo de empobrecimento do movimento "bandístico" no pós-Segunda Guerra Mundial. A revista Arte Musical apresenta, ao longo da década de 1930, um grande número de artigos e noticias que demonstram bem a actividade das bandas, tanto Civis como Militares. Logo no $1^{\circ}$ número de 1 de Janeiro de 1930, Guerra Pais escreve um artigo intitulado Bandas de Música Civis Portuguesas onde calcula existirem no país cerca de 1000 "agrupamentos musicais constituídos por amadores" e afirma que cada um tem uma média de 20 elementos. No n $^{\circ} 29$, de 20 de Outubro de 1931, num artigo intitulado Bandas Civis assinado com as iniciais J.P. é referida a existência de 3000 bandas e mais tarde, no no 46 de 10 de Julho de 1932, Raul Morais Franco, em artigo intitulado Bandas Civis: sociedades musicais e recreativas, agremiações de utilidade pública, refere que as bandas deverão ser 2500 e, por análise dos valores que apresenta, cada uma seria composta por uma média de 35 músicos. O número de 3000 bandas avançado por J.P. parece-nos excessivo e somos levados a aceitar como credível um valor intermédio entre a afirmação de Guerra Pais e a de Raul Morais Franco. Pedro de Freitas (Freitas, 1946: 536), citando o livro de clientes da casa "Custódio Cardoso Pereira e Ca", calcula que seriam cerca de 800 as bandas existentes em meados da década de 1940. Esta quebra, entre os números avançados nos diferentes artigos da Arte Musical e o livro de Pedro de Freitas, é consistente com o discurso de empobrecimento das bandas que o próprio Pedro de Freitas refere de forma sistemática ao longo de todo o seu trabalho. Infelizmente esta crise continuaria a crescer levando a que, no início da década de 1970 e segundo um inquérito promovido pela Secção de Etnografia e Sociedades Recreativas da Secretaria de Estado da Informação e Turismo, existissem apenas 422 bandas em actividade sendo que 232 dessas Bandas afirmam estar carentes de instrumentistas como resultado directo da emigração.

Naturalmente que esta crise, tanto no número total de bandas como no número de instrumentistas naquelas que conseguem resistir, teve um impacto enorme na qualidade e variedade do repertório praticado. Se é 
um facto que encontramos algumas vozes críticas, vindas tanto do seio das próprias bandas como de personalidades estranhas a estas, quanto á escolha do repertório interpretado nas primeiras décadas do séc. $\mathrm{xx}$, também é verdade que, pela análise de notícias ou críticas publicadas em diferentes periódicos, dos quais podemos citar novamente a Arte Musical, se podem encontrar referências a um repertório bastante ecléctico que vai da marcha militar ao poema sinfónico, passando por rapsódias, fantasias, pequenas peças concertantes, aberturas e pout-pourris de óperas, etc. É notável, até pela sua actualidade, um conjunto de 3 textos, publicados nos números 156, 176 e 177 da Arte Musical, acerca do repertório das bandas, tanto militares como civis, que, embora não estando assinados, julgamos terem sido escritos por Luís de Freitas Branco. Nestes artigos ele defende que as bandas, em vez de apoiarem o seu repertório em transcrições de aberturas de ópera e obras de carácter ligeiro de qualidade duvidosa, deveriam olhar para o repertório para conjuntos instrumentais de sopros dos grandes mestres (Mozart, Beethoven, Strauss, Rimsky-Korsakov, Gounod, Schubert, Hindemith, etc.) como base para melhorar a qualidade do seu repertório afirmando que, mesmo tendo de substituir oboés, fagotes e até trompas por outros instrumentos da banda, a escolha deste repertório seria preferível à transcrição de obras escritas para orquestra sinfónica.

Muito do repertório original escrito para banda, tanto de autores portugueses como estrangeiros, que se tocou nas primeiras décadas do séc. $\mathrm{xx}$ foi caindo progressivamente em desuso à medida que as bandas perdiam capacidade para o interpretar. Se em tempos foi possível a muitas Bandas interpretar obras como Alsaciâna, escrita em 1917 por João Carlos de Sousa Moraes e cuja partitura necessita, no mínimo, de 31 instrumentistas para se poder interpretar, chegados à década de 1960, aparecem-nos vários exemplos de partituras que podem ser tocadas usando apenas 12 instrumentistas o que diz bem da incapacidade de um grande número de bandas para interpretar o repertório que havia sido escrito no início do século.

Constata-se também que o repertório original para banda que se ia produzindo noutros países não tinha grande penetração em Portugal. Não se conhecem relatos de interpretações das Suítes para banda de Gustav Holst ou das obras para banda de Vaughan Williams, de Gordon Jacob, de Paul 
Hindemith, de Ernest Toch, de Florent Schmidt, de Paul Fauchet, de Vincent Persichetti e de outros autores que produziram música para banda durante a primeira metade do séc. xx que ainda hoje é reconhecida como repertório de referência no universo das orquestras de sopro. É curioso verificar que a maior parte das obras impressas adquiridas a editoras estrangeiras que se encontram nos arquivos das bandas são arranjos ou transcrições de obras para orquestra e menos obras originais para banda que essas editoras também disponibilizavam. Talvez aqui a falta de conhecimento dos maestros em relação à existência de um repertório original e a familiaridade dos títulos das obras transcritas tenha contribuído para esta realidade.

Ao olharmos para o repertório apresentado no "I Concurso Nacional de Bandas Civis" organizado pela Fundação Nacional para a Alegria no Trabalho (F.N.A.T.) entre Dezembro de 1959 e Setembro de 1960, e que teve Pedro de Freitas como organizador responsável, facilmente verificamos o peso que as transcrições de obras de orquestra tinham no repertório das Bandas Amadoras Comunitárias. Um facto positivo é o de as peças obrigatórias da primeira eliminatória para cada uma das 3 categorias do concurso serem todas originais para banda e de autores portugueses: Rapsódia de Cantos Populares do Baixo Alentejo de Sousa Moraes, Capricho Varino de Silva Marques e Rapsódia Ligeira de Armando Escoto. Como o regulamento estabelecia que na primeira eliminatória apenas fosse interpretada uma Marcha e a peça obrigatória, temos de olhar para as obras interpretadas na segunda eliminatória e na final para ter uma melhor percepção do repertório tido como referência para os maestros das Bandas: das 61 bandas que se apresentaram na segunda eliminatória 6 escolheram como obra livre uma peça original para banda de um autor estrangeiro ${ }^{126}, 19$ escolheram uma obra original para banda de autor português e 36 escolheram interpretar como obra livre uma transcrição de uma obra para orquestra. A peça obrigatória para as bandas concorrentes na $1^{a}$ Categoria para esta segunda eliminatória era também uma transcrição. Na Final, onde participaram apenas 3 bandas de cada categoria, e não obstante

126 É de notar que 4 destas 6 bandas escolheram a mesma obra: Princess of India do compositor americano Karl King. Temos portanto 3 obras originais para banda de autores estrangeiros sendo que nenhuma destas figura como obra digna de referência no contexto da história do repertório de música para sopros, pese embora Karl King seja reconhecido internacionalmente pela qualidade das suas marchas de cariz militar. 
as peças obrigatórias da $1^{\mathrm{a}}$ e $3^{\mathrm{a}}$ Categorias serem transcrições de obras para orquestra, apenas uma banda, na $1^{\text {a }}$ Categoria apresentou uma transcrição que foi a Rapsódia Eslava de David de Sousa.

É pois num clima de degradação constante das potencialidades artísticas e de um repertório muito dominado por transcrições, nomeadamente no que diz respeito ao repertório tido como mais sério, que as Bandas Amadoras Comunitárias chegam à década de 1970. É nesta altura que começam a surgir com mais insistência algumas acções que tentam chamar a atenção das autoridades políticas e agentes sociais e culturais para as dificuldades que estas atravessam e que se reflectem logicamente num empobrecimento cultural, social e educativo das populações, sobretudo nas zonas rurais do país. É óbvio que o envolvimento da F.N.A.T. na organização do já referido Concurso, e nomeadamente a acção de Pedro de Freitas como organizador e também como "porta-voz" das Bandas, tinha já servido para por um lado para mostrar o impacto sociocultural das bandas e por outro as dificuldades por que passavam. Ainda antes da Revolução Democrática organiza-se uma série de mesas redondas, reuniões e colóquios, uns de âmbito nacional outros regional, onde participam algumas das personalidades que tinham estado envolvidas como membros do júri no Concurso da F.N.A.T. como Manuel da Silva Dionísio, Humberto d'Ávila e Marcos Romão dos Reis Júnior, e que pretendem não só chamar a atenção para as dificuldades das bandas como também apontar soluções a adoptar para resolver alguns desses problemas. A Federação Portuguesa das Colectividades de Cultura e Recreio (F.P.C.C.R.), de cuja direcção fazia parte Humberto d'Ávila, toma também especial interesse nesta luta pela defesa e dignificação das Bandas Amadoras e em conjunto com a F.N.A.T. e com a Direcção-Geral da Cultura Popular e Espectáculos (D.G.C.P.E.) dá corpo a várias iniciativas como Cursos de Férias para formação de maestros e jovens instrumentistas das bandas e promove Concursos Nacionais de Aprendizes de Música destinados a incentivar os jovens músicos das bandas. É no entanto de uma série de reuniões realizadas na sede da F.P.C.C.R. nos dias 7 de Abril, 25 de Abril e 19 de Maio de 1973 que emergem algumas conclusões que correspondem aquilo que viria a ser, em certa medida, a política de apoio às Bandas Amadoras desde 1975 até meados da década de 1980. 


\section{As Acções de Apoio da S.E.C. às Bandas Amadoras}

Das reuniões realizadas na F.P.C.C.R. surgem uma série de ideias que Silva Dionísio, que havia sido nomeado representante da D.G.C.P.E. nestes encontros, relata ao Director-Geral a 15 de Junho de 1973. No início deste relatório Silva Dionísio cita três afirmações que o "impressionaram pela sua justeza ou pela sua razão prática” das quais destacamos a de Álvaro Salazar, representante da J.M.P. nesta reunião, que terá defendido que " a principal causa de desprestígio das filarmónicas além dos prejuízos técnicos - afinação, execução - é a pobreza do antiquado repertório. É necessário renová-lo a todo custo”. Silva Dionísio transcreve ainda algumas ideias debatidas quanto às causas do declínio das bandas, que vão de certa forma ao encontro do que já acima apresentámos, e enumera uma lista de dez "acções convergentes", a serem implementadas ou apoiadas por todas as entidades que estavam representadas nestas reuniões. Destas destacamos cinco que vêm mais tarde a florescer no plano de acção da Divisão de Música da S.E.C.: disponibilização de ajuda económica às Sociedades que provem dela precisar, criação de cursos intensivos de direcção de Banda, criação de cursos de férias para os jovens músicos das bandas, fomentar a composição musical para banda "com encomendas a compositores [portugueses] de reconhecido mérito", promover transcrições para Banda de obras consideradas clássicas "depois de uma escolha criteriosa debaixo do ponto de vista dos resultados a obter no auditório a que se destinam".

Romeu Pinto da Silva, chefe da Divisão de Música da S.E.C., foi quem contribuiu decisivamente para por em prática uma estratégia de apoio às bandas amadoras. Esta estratégia teve por base uma constante e frutífera troca de ideias com Silva Dionísio ao ponto de Pinto da Silva considerar Silva Dionísio o grande inspirador da acção da S.E.C. junto das bandas. A estratégia, que podemos adjectivar de integrada, passou por um plano de financiamento da compra de instrumentos musicais para as bandas (a ser posto em prática de forma faseada e por distritos, recorrendo a verbas inscritas directamente no PIDAAC), o financiamento à manutenção das escolas de música das bandas, e a atribuição de apoios para acções de formação para maestros ${ }^{127}$ e jovens

\footnotetext{
127 Viria mesmo a ser publicado um Guia Teórico e Prático para Regentes de Bandas Civis da autoria do Capitão Chefe de Música Fernando de Matos Simões, que tinha por objectivo servir de base para estas acções de formação.
} 
músicos das bandas através de cursos intensivos coordenados muitas vezes com o INATEL e até com a Fundação Calouste Gulbenkian. A partir de 1977, passa a figurar também nesta estratégia, a encomenda de obras "expressamente concebidas para serem distribuídas a todas as Filarmónicas". Este projecto de encomendas de obras viria a incluir não apenas obras originais como também transcrições de repertório cujo interesse artístico-pedagógico se julgava importante não só para os músicos das bandas como também para o seu público.

\section{As Obras Originais do Projecto de Encomendas da S.E.C.}

Dependendo da forma como se contabilize o trabalho realizado por Joly Braga Santos, foram produzidas no total 10 ou 11 obras originais para banda no período entre 1977 e 1983. A orquestração proposta aos compositores decorre sem dúvida daquilo que era o conhecimento prático de Silva Dionísio sobre as bandas amadoras portuguesas da época. Na Tabela I podemos observar as combinações instrumentais usadas em cada obra. Para permitir a leitura da tabela apresentamos abaixo a correspondência entre as abreviaturas e as respectivas obras organizadas, tal como nas descrições subsequentes, por ordem cronológica:

S.R. - Suite Rústica $n^{\circ}$ 3, Op. 203 de Fernando Lopes-Graça

H.P. - Homenagem ao Povo de Álvaro Cassuto

M.I.S.P. - Música para Instrumentos de Sopro de Percussão de Joly Braga Santos

N. - Nocturno de Joly Braga Santos

C.D.M. - Coros e Danças Medievais de Cândido Lima

RONDO - Rondó, Op. 34 de Maria de Lourdes Martins

R.N. - Rapsódia de Natal, Op. 35 de Maria de Lourdes Martins

S.B. - Suite para Banda, Op. 36 de Maria de Lourdes Martins

R.M. - Romaria Minhota de Manuel Faria

F.C. - Fantasia Campestre de Frederico de Freitas 
Tabela 1 - Comparação da orquestração utilizada em cada uma das obras originais

S.R. H.P. M.I.S.P. N. C.D.M. RONDO R.N. S.B. R.M F.C.

\begin{tabular}{|c|c|c|c|c|c|c|c|c|c|c|}
\hline Flautim & $*$ & $*$ & $*$ & $*$ & $*$ & $*$ & $*$ & $*$ & $*$ & $*$ \\
\hline Flauta & $*$ & * & $*$ & $*$ & $*$ & $*$ & $*$ & $*$ & $*$ & $*$ \\
\hline Oboé & & & & $*$ & & & & & & $*$ \\
\hline Fagote & & & & $*$ & & & & & & $*$ \\
\hline Requinta & $*$ & $*$ & $*$ & $*$ & $*$ & $*$ & $*$ & $*$ & $*$ & $*$ \\
\hline Clarinete I & $*$ & * & $*$ & $*$ & $*$ & $*$ & $*$ & $*$ & $*$ & $*$ \\
\hline Clarinete II & $* 1$ & $*$ & $*$ & $*$ & $*$ & $*$ & $*$ & $*$ & $*$ & $*$ \\
\hline Clarinete III & $* 1$ & $*$ & $*$ & $*$ & * & $*$ & $*$ & $*$ & $*$ & $* 1$ \\
\hline Clarinete Baixo & & & & $*$ & & & & & & $*$ \\
\hline Sax Soprano & $*$ & $*$ & $*$ & $*$ & $*$ & $*$ & $*$ & $*$ & $*$ & $*$ \\
\hline Sax Alto & $*$ & $*$ & $*$ & $*$ & $*$ & $*$ & $*$ & $*$ & $*$ & $*$ \\
\hline Sax Tenor & $*$ & $*$ & $*$ & $*$ & $*$ & $*$ & $*$ & $*$ & $*$ & $*$ \\
\hline Sax Barítono & $*$ & $*$ & $*$ & $*$ & $*$ & $*$ & $*$ & $*$ & $*$ & $*$ \\
\hline Fliscorne I & $*$ & $*$ & $*$ & $*$ & $*$ & $*$ & $*$ & $*$ & $*$ & $*$ \\
\hline Fliscorne II & $*$ & $*$ & $*$ & $*$ & $*$ & $*$ & $*$ & $*$ & $*$ & $*$ \\
\hline Trompete I & $*$ & $*$ & $*$ & $*$ & $*$ & $*$ & $*$ & $*$ & $*$ & $*$ \\
\hline Trompete II & $*$ & $*$ & $*$ & $*$ & $*$ & $*$ & $*$ & $*$ & $*$ & $*$ \\
\hline Trompete III & & $*$ & & $*$ & * & $*$ & * & $*$ & $*$ & \\
\hline Trompete IV & & & & $*$ & & & & & & \\
\hline Sax Trompa I & $*$ & $*$ & $*$ & $*$ & $*$ & $*$ & $*$ & $*$ & $*$ & $*$ \\
\hline Sax Trompa II & $*$ & & $*$ & $*$ & $*$ & $*$ & $*$ & $*$ & $*$ & $*$ \\
\hline Sax Trompa III & $*$ & & & $*$ & * & & & & & \\
\hline Sax Trompa IV & & & & $*$ & & & & & & \\
\hline Trombone I & $*$ & $*$ & $*$ & $*$ & $*$ & $*$ & $*$ & $*$ & $*$ & $*$ \\
\hline Trombone II & $*$ & $*$ & $*$ & $*$ & $*$ & $*$ & $*$ & $*$ & $*$ & $*$ \\
\hline Trombone III & $*$ & $*$ & $*$ & $*$ & $*$ & $*$ & $*$ & $*$ & $*$ & $*$ \\
\hline Bombardino I & $*$ & $*$ & $*$ & $*$ & $*$ & $*$ & $*$ & $*$ & $*$ & $*$ \\
\hline Bombardino II & $*$ & * & $*$ & $*$ & $*$ & $*$ & $*$ & $*$ & $*$ & $*$ \\
\hline Bombardino III & & & & $*$ & & & & & & \\
\hline Tuba Mib & $*$ & $*$ & $*$ & $*$ & $*$ & $*$ & $*$ & $*$ & $*$ & $*$ \\
\hline Tuba Sib & $*$ & $*$ & $*$ & $*$ & * & $*$ & $*$ & $*$ & $*$ & $*$ \\
\hline Glockenspiel & & $*$ & & $*$ & & & & & & \\
\hline Carrilhão Sinos & & & & & $*$ & & & & $*$ & \\
\hline Tímpanos & & $*$ & & $*$ & $*$ & & & & $*$ & $*$ \\
\hline $\begin{array}{l}\text { Bombo, Caixa, } \\
\text { Pratos }\end{array}$ & $*$ & $*$ & $*$ & $*$ & $*$ & $*$ & $*$ & $*$ & $*$ & $*$ \\
\hline Outra Percussão & $*$ & * & $*$ & $*$ & $*$ & $*$ & $*$ & $*$ & $*$ & $*$ \\
\hline
\end{tabular}




\section{Fernando Lopes-Graça}

Lopes-Graça respondeu à encomenda da S.E.C. escrevendo a sua Suíte Rústica No3, Op. 203. Concluída a 26 de Fevereiro de 1977, está estruturada em seis andamentos: 1 - Prelúdio Alentejano, 2 - Cena Transmontana, 3 - Cerimónia Religiosa na Beira-Baixa, 4 - A Beira-Alta de Visita ao Alentejo, 5 - Toada de Rimance com três Variações, 6 - O Minho Dança. Nesta obra Lopes-Graça retoma em termos macro-formais a estrutura que utilizou na Suíte Rústica $N^{\circ} 1$ para Orquestra, também esta em 6 andamentos, com títulos decalcados da tradição musical portuguesa, e com uma organização idêntica no que diz respeito ao carácter dos andamentos; diferindo um pouco da Suíte Rústica $N^{\circ} 2$, para quarteto de cordas, composta de apenas 5 andamentos e com títulos que sugerem uma maior estilização da música tradicional. A obra viria a ser estreada a 16 de Dezembro 1981, pela Banda Sinfónica da Guarda Nacional Republicana dirigida por Alves Amorim, num concerto comemorativo do $75^{\circ}$ aniversário do autor, realizado no Teatro da Trindade. Lopes-Graça, como era seu hábito, fez primeiro um muito completo rascunho para piano da obra e depois produziu a partitura para banda mas sem transposições. Esta opção, motivada talvez por um desconhecimento, não das transposições em si mas do que era a prática dos instrumentistas das bandas amadoras, contribuiu para um autêntico desastre editorial da obra. A partitura transposta e respectivas partes que foram produzidas pela S.E.C. em 1979 e que estão assinadas pelo copista Joaquim Martelo, estão pejadas de erros de notas, de transposição de oitavas sobretudo nas sax--trompas alto e nos saxofones alto e tenor, erros em articulações e dinâmicas, etc.. Estes problemas editoriais criaram um enorme obstáculo à disseminação da obra uma vez que durante cerca de 20 anos estes foram os únicos materiais disponíveis sendo, em boa verdade, inúteis.

\section{Álvaro Cassuto}

Para convencer Álvaro Cassuto a escrever uma obra para banda, Silva Dionísio convida-o a assistir a um concerto da Banda Música da Sociedade Filarmónica Humanitária de Palmela. Impressionado com a prestação da banda, 
Cassuto decide escrever Homenagem ao Povo. A peça está claramente estruturada sob a forma de uma rapsódia composta de 6 temas tradicionais, de diversas regiões portuguesas, que foram transcritos pelo autor a partir, por exemplo, dos discos da Antologia da Música Regional Portuguesa resultado da recolha levada a cabo por Michel Giacometti e Fernando Lopes-Graça. Ao fazer uso de música tradicional foi intenção explícita do autor por um lado prestar homenagem à capacidade criativa do povo português e ao mesmo tempo garantir, por força desses temas, uma fácil identificação dos possíveis intérpretes, leia-se músicos das bandas amadoras, com o conteúdo musical da obra. A peça viria a ser concluída a 10 de Junho de 1977 e dedicada "Ao Maestro Silva Dionísio em agradecimento pelos seus conselhos; à Banda de Música da Sociedade Filarmónica Humanitária de Palmela, com apreço; e ao Povo de Portugal, modesta homenagem". Do ponto de vista editorial a obra apresenta desde algumas notas erradas, incongruências em dinâmicas e articulações até problemas mais graves que se prendem com opções de instrumentação, sobretudo nas diferentes vozes dos clarinetes, com dobragens de vozes no registo mais agudo, reforçadas por vezes com o uníssono de flauta e flautim o que tornava certas passagens da obra impraticáveis de forma aceitável sobretudo por instrumentistas amadores. Em 1992 foi feita uma nova instrumentação da obra, pelo maestro José Eduardo Ferreira da Banda dos Loureiros de Palmela, com significativas alterações à instrumentação original, tendo a obra sido estreada dessa forma nesse mesmo ano. A estreia de uma versão revista da orquestração original, com a colaboração do autor, foi feita em Outubro de 2008 pela Banda da União Filarmónica do Troviscal.

\section{Joly Braga Santos}

O contributo de Joly Braga Santos para o projecto de repertório da S.E.C. ficaria conhecido como Otonifonias, Op.56. No entanto, sob este título encontramos agrupados dois manuscritos que em boa verdade se podem considerar duas obras autónomas. O primeiro manuscrito concluído a 21 de Outubro de 1977 intitula-se Música para Instrumentos de Sopro e Percussão (uma suite em quatro andamentos) e o segundo, datado de 12 de Novembro de 1977, 
intitula-se Nocturno. Como se pode ver pela Tabela I a orquestração do Nocturno pressupõe uma banda muito mais rica instrumentalmente do que Música para Instrumentos de Sopro e Percussão, e muito mais rica do que a quase totalidade das outras obras do projecto de encomendas. Também do ponto de vista da escrita esta peça está claramente mais elaborada sendo desde logo muito menos homofónica do que os quatro andamentos que compõem a Música para Instrumentos de Sopro e Percussão. O propósito do título Otonifonias é-nos revelado numa nota de programa de concerto da Banda da Armada portuguesa, provavelmente de 1979, em que foi interpretada a Música para Instrumentos de Sopro e Percussão, e onde se constata que Otonifonias pretendia vir a ser um conjunto de seis suites, de quatro andamentos cada, com graus progressivos de dificuldade que Joly se propunha escrever para o projecto. A data posterior, a instrumentação mais rica e o estilo de escrita um pouco diferente levam-nos a crer que Nocturno poderia ser já um dos andamentos de uma segunda suite da qual não se conhecem mais andamentos. Música para Instrumentos de Sopro e Percussão (com o título de Otonifonias) foi estreada em 1978 no Teatro da Trindade, num concerto da Banda da Guarda Nacional Republicana, sob a direcção de Alves Amorim. O Nocturno ter-se-á mantido inédito uma vez que não figura nenhuma partitura da obra no arquivo musical da Banda da Guarda Nacional Republicana nem sequer existem partes cavas disponíveis no arquivo musical da DGArtes. Do ponto de vista editorial estas obras não apresentam grandes problemas apenas pequenas discrepâncias de articulações e de uma ou outra nota errada sobretudo nos instrumentos transpositores.

\section{Cândido Lima}

Se pusermos de parte a Missa em Honra de S. Jorge de Manuel Faria que em boa verdade não é para banda completa e não pensarmos o Nocturno de Joly como uma peça autónoma, a obra Coros e Danças Medievais de Cândido Lima é a única obra de todo o projecto que não tem qualquer ligação à música tradicional portuguesa. Estruturada em dez andamentos, uns encadeados outros não, a obra é, na ideia do próprio compositor, uma tentativa de aproximação 
da banda e dos seus músicos a linguagens musicais medievais com referências estilísticas, umas evidentes outras mais subtis, aos estilos polifónicos dos períodos da Ars Antíqua e da Ars Nova. Os diferentes andamentos da obra resultam de pequenas peças vocais e/ou vocais com acompanhamento instrumental, que Cândido Lima tinha previamente escrito, entre 1968 e 1975, para grupos amadores com quem tinha trabalhado. Daí se percebe a dedicatória da obra "aos grupos corais e instrumentais amadores de todo o país". Do ponto de vista técnico a obra apresenta no entanto dificuldades de interpretação da escrita que Cândido Lima não teve porventura consciência na época e que dificultavam grandemente execução da obra por bandas amadoras. Estas dificuldades resultam por exemplo da sobreposição de "incrustações", para usar o termo do próprio autor, que um instrumentista ou grupo de instrumentistas teriam de interpretar independentemente do resto da banda, apenas por indicação do maestro. Este género de solicitação estava completamente fora de qualquer prática musical a que os músicos das bandas estivessem acostumados. O manuscrito apresenta poucas notas erradas, algumas inconsistências de articulações e dinâmicas e algumas passagens escritas demasiado no limite superior das tessituras de alguns instrumentos (quando não acima destes, dependendo das capacidades técnicas do músico). Foram produzidas na época partes cavas manuscritas que no entanto são inúteis para a execução da obra já que o copista que as produziu não deveria ter experiência em cópia de obras com escrita mais contemporânea e não indica devidamente nas partes as diferentes "incrustações", os compassos de espera entre incrustações, os compassos de espera dentro de cada andamento e entre andamentos, optando por indicações do tipo "tacet até ao final" o que não funciona de todo quando os andamentos estão ligados. A obra permaneceria inédita até Novembro de 2011 quando foi tocada e gravada, pela North Texas Wind Symphony, após longo trabalho de revisão e edição com a colaboração do compositor.

\section{Maria de Lourdes Martins}

Para este projecto de encomendas Maria de Lourdes Martins escreveu três obras todas elas baseadas em música tradicional portuguesa: Rondó Op. 34, 
Rapsódia de Natal Op. 35 e Suite para Banda Op. 36. Pelas datas inscritas nos Op. 34 e Op. 36, podemos concluir que esta trilogia foi escrita entre Setembro e Dezembro de 1978. O Rondó, baseado em dez "Canções Infantis da Tradição Portuguesa" terá sido a única estreada. Tal conclusão é suportada pelo facto de apenas desta se conseguir encontrar partitura com marcações para direcção, posse de Silva Dionísio, e respectivas partes cavas. Tanto a partitura como as partes apresentam poucos erros, apenas algumas inconsistências de dinâmicas e articulações, sendo perfeitamente possível interpretar a obra usando estes materiais.

A Rapsódia de Natal está construída sobre nove canções de Natal portuguesas sendo que, o uso recorrente da primeira canção como ponte entre os vários temas da rapsódia, um pouco à imagem da construção usada no Op. 34, fazem com que esta rapsódia nos dê também uma sensação de rondó. Os problemas editoriais desta obra prendem-se apenas com pequenas dúvidas de altura de notas sobretudo quando há divisi nas partes, e ainda alguma falta de coerência de articulações e dinâmicas.

A Suite para Banda, subintitulada Danças do Folclore Português, apresenta uma construção macro-formal interessante. Em primeiro lugar os treze "andamentos" que constituem a suite estão pensados de forma a serem tocados sem interrupções, alguns estão mesmo ligados por pontes que sugerem uma construção rapsódica e não uma tradicional suite. Em segundo lugar, a maior parte dos "andamentos", cujos títulos correspondem de facto a danças tradicionais, ou pelo menos géneros da música tradicional portuguesa, são constituídos por diferentes temas que representam diferentes variedades regionais de cada uma dessas danças. A título de exemplo, o Malhão é composto por um malhão do Douro, um da Beira Alta, um de Arganil e por um outro não identificado. No total, a compositora identifica 28 temas tradicionais usados na criação da obra. Os problemas editoriais nesta obra são do mesmo género dos da Rapsódia de Natal.

\section{Manuel Faria}

Manuel Faria produziu duas obras diferentes para o projecto: Missa em Honra de S. Jorge e Romaria Minhota. A Missa em Honra de S. Jorge, datada 
de Abril de 1978 e dedicada "a Albano Coelho de Lima e à sua Banda de Pevidém", é aquilo que podemos considerar uma missa brevis destinada claramente ao uso corrente no culto católico. Foi instrumentada originalmente para coro a duas vozes iguais, flauta, 3 clarinetes, saxofone alto, saxofone tenor, saxofone barítono e órgão ou harmónio ad libitum. Estrutura-se em Prece Litânica, Hino Angélico (Glória), Triságio (Santo) e Oração da Paz (Cordeiro de Deus) e tal como se pode antecipar está escrita em português. Em 1983, na Nova Revista de Música Sacra (2 ${ }^{\text {a }}$ Série, $\mathrm{N}^{\circ} 27-28$ ), viria a ser publicada uma versão posterior da obra, para coro a quatro vozes mistas com acompanhamento de órgão, lendo-se em nota de rodapé que esta nova versão poderia ser interpretada recorrendo ao instrumental da versão original. Não se sabe se a obra terá sido interpretada na época na sua versão original sendo que, a versão final para coro misto acompanhada pelo ensemble de sopros original foi estreada em Junho de 2007.

Romaria Minhota é uma suite em três andamentos: 1 - Por Caminhos e Sendas (Chula), 2 - Cântico à Senhora, 3 - Dança Final. Para escrever esta obra Manuel Faria recorreu, pelo menos parcialmente, a obras escritas anteriormente. Não tendo sido ainda concluída a pesquisa e leitura de todos os manuscritos e rascunhos do compositor, constata-se no entanto que o $3^{\circ}$ andamento, Dança Final, é uma transcrição para banda da Dança Minhota sobre Dois Temas Populares, escrita em Maio de 1962 para orquestra de câmara. O manuscrito autógrafo de Romaria Minhota não foi ainda localizado, conhecendo-se apenas a cópia manuscrita assinada por Francisco Ribeiro em Janeiro de 1979. O exemplar desse manuscrito que se encontra no arquivo da Biblioteca Geral da Universidade de Coimbra, e que portanto fazia parte do arquivo pessoal do compositor, apresenta-se sem rasuras ou anotações mas tem apensa uma pequena nota manuscrita com indicação de alterações a fazer à partitura. Os exemplares existentes no arquivo da DGArtes estão rasurados e anotados e foi possível descobrir, por entre diversos documentos não catalogados no arquivo da DGArtes, fragmentos de papel de música, escritos pela mão de Manuel Faria, contento as alterações que constam na nota anexa à partitura da B.G.U.C. o que revela que este ter-se-á dado conta dos erros já depois de entregar a obra na S.E.C. e enviou as "erratas" para serem apensas ou corrigidas nas partituras produzidas. Apesar das erratas 
produzidas por Manuel Faria a obra apresenta ainda alguns erros de orquestração nomeadamente no que se refere ao saxofone soprano com passagens escritas que ultrapassam o limite inferior da tessitura deste instrumento.

\section{Frederico de Freitas}

A Fantasia Campestre, contributo de Frederico de Freitas para o projecto, é uma rapsódia composta por temas, tanto quanto se percebe, originais mas numa explícita aproximação à música tradicional. De todas as obras do projecto, esta é a que mais questões levanta desde a sua origem até à sua edição. Os materiais que se encontram em arquivo na DGArtes, partitura e partes, estão todos assinados pelo copista Joaquim Martelo e datam de 1983, 3 anos após a morte do compositor. O rascunho da obra, actualmente na Universidade de Aveiro, está escrito para piano e não se encontra neste arquivo nenhuma outra versão da obra que sugira uma orquestração para banda pela mão do compositor. Romeu Pinto da Silva afirma que Fantasia Campestre não teria sido o título originalmente pensado por Frederico de Freitas mas sim Arco-Íris (é com este título que o compositor se refere à peça em carta endereçada a Manuel Faria a 18 de Março de 1977) ou Aguarela Lusitana, mas que Silva Dionísio o teria demovido desse intento dado já existirem obras muito conhecidas para banda com os mesmos títulos. Este relato é consistente com as primeiras páginas do rascunho onde estão inscritos vários títulos, uns rasurados e outros não: Paisagem Portuguesa, Aguarela Lusitana e Paisagem Lusitana.

A convicção de que a orquestração não terá sido feita por Frederico de Freitas é suportada por uma pequena anotação existente no canto inferior direito da página 23 do rascunho onde o colaborador que estaria a fazer a orquestração questiona sobre o local onde deve colocar um sinal de repetição, anotação esta datada de 10 de Maio de 1977. Mesmo uma análise superficial da partitura final deixa imediatamente perceber uma orquestração com constante duplicação de vozes, grande falta de contraste no colorido instrumental e com opções idiomáticas pouco credíveis para um orquestrador como Frederico de Freitas, dando-nos a sensação de estarmos perante uma transcrição "literal" 
para banda, feita directamente a partir do rascunho de piano por alguém com pouco treino e criatividade em orquestração para banda. Segundo carta enviada a Manuel Faria a 25 de Junho de 1977, Frederico de Freitas refere como estando concluído o trabalho de composição da Fantasia Campestre. Podemos pois fixar a conclusão da obra entre 10 de Maio e 25 de Junho de 1977. O hiato até à produção dos materiais finais, 1983, foi até agora impossível de explicar Do ponto de vista editorial, os materiais produzidos em 1983 apresentam vários erros de notas e articulações e o resultado da instrumentação é denso, monótono e tecnicamente cansativo mesmo para instrumentistas experientes, tal como ficou demonstrado numa gravação produzida pela orquestra de sopros do Royal Northern College of Music. Decidiu-se pois fazer uma re-orquestração da obra, com base no rascunho, mas sem ignorar a partitura final uma vez que nada sabemos sobre instruções específicas que o compositor possa ter dado ao seu colaborador.

\section{Conclusão}

A acção da S.E.C. junto das Bandas Amadoras ficará provavelmente para a história da cultura musical portuguesa como o único exemplo de uma estratégia concertada e integrada de uma política cultural que, visando actuar sobre uma prática de cariz amador, pretendia colmatar a falta de potencial profissional disponível para levar a cultura musical a todo o território. No contexto das dezenas de projectos semelhantes que em diferentes períodos da história da música do séc. xx foram florescendo um pouco por todo o mundo, o da S.E.C. tem a particularidade interessante de aliar, à vontade de querer criar bom repertório para as bandas tocarem, fazer depois uso das bandas como veículo de promoção artística, descentralizada e abrangente, de um público à escala nacional.

O projecto de encomendas em concreto falhou no seu objectivo uma vez que na época apenas três das onze obras foram estreadas e apenas duas, a Suite Rústica $n^{\circ} 3$ e a Música para Instrumentos de Sopro e Percussão, voltariam a ser tocadas e mesmo estas com uma regularidade e disseminação que não se pode concluir que tenham influenciado o repertório das Bandas Amadoras. 
As hipóteses que aventamos para este fracasso são várias:

- a não existência em Portugal de uma empresa de edição musical, pelo que não havia forma eficiente de fazer chegar as obras às Bandas;

- a incapacidade para promover um trabalho posterior de correcção e edição dos manuscritos entregues pelos compositores o que impediu certamente que mais obras fossem estreadas.

- o facto da maioria dos Maestros e músicos não terem preparação para compreender ou interpretar algumas destas obras, não que elas fossem tecnicamente muito mais difíceis do que outras que as bandas tocavam, mas a opção da maioria dos compositores em trabalhar a banda numa linguagem quase "camarística" obrigava a um salto idiomático em relação ao anterior repertório que para muitos não fazia sentido e era de difícil concretização em bandas amadoras;

- o protesto e incompreensão por parte de alguns músicos militares, que eram também compositores e directores de banda, e que reclamavam para si o conhecimento prático de escrever para banda o que levou a uma recusa em aceitar o projecto.

As bandas voltariam a florescer, devido em parte a todas as outras vertentes da estratégia inicial da S.E.C., e calcula-se hoje que o número total de bandas ronde as 800 o que equivale a dizer que estão ao nível de meados da década de 1940. Em termos qualitativos estão no entanto num nível que nunca antes atingiram, a desenvolver repertório não só da grande tradição histórica, que já acima mencionámos, como inclusive a promover a encomenda de obras a jovens compositores que foram, alguns deles, alunos da geração que trabalhou no projecto da S.E.C.

Quanto às obras encomendadas pela S.E.C., perante esta nova geração de bandas e de maestros, poderão servir para o estabelecimento de uma linha contínua de repertório para banda de autores portugueses estando a despertar cada vez mais a curiosidade dos actuais actores do universo das Bandas Amadoras Comunitárias portuguesas... e não só! 


\section{Bibliografia}

[Branco, Luís de Freitas] (1935) "O Repertório das Bandas Civis", Arte Musical, 156: 1-2.

[Branco, Luís de Freitas] (1935) "Repertório Elevado para Instrumentos de Sôpro", Arte Musical, 176: 1.

[Branco, Luís de Freitas] (1935) "Mais Repertório para Instrumentos de Sôpro", Arte Musical, 177: 1.

Brucher, Katherine (2005). A Banda da Terra: Bandas Filarmónicas and the Performance of Place in Portugal. Dissertação de Doutoramento em Musicologia. University of Michigan Ann Arbour.

Dionísio, Manuel da Silva (1973) "Relatório". Fundo Documental da Banda Sinfónica da Guarda Nacional Republicana. Não Catalogado.

Faria, Cristina Adriana Toscano de (1992). Manuel Ferreira de Faria: o homem e o sacerdote/o compositor e o pedagogo. Tese de Mestrado. Faculdade de Letras da Universidade de Coimbra.

Franco, Raul Morais (1932) "Bandas Civis: sociedades musicais e recreativas, agremiações de utilidade pública", Arte Musical 46: 6.

Freitas, Frederico (1977) Carta a Manuel Faria de 18 de Março de 1977. Biblioteca da Universidade de Aveiro, Espólio Frederico de Freitas, Correspondência Enviada a Manuel Faria, Pasta 2, Bolsa 9.

Freitas, Frederico (1977b) Carta a Manuel Faria de 25 de Junho de 1977. Biblioteca da Universidade de Aveiro, Espólio Frederico de Freitas, Correspondência Enviada a Manuel Faria, Pasta 2, Bolsa 9.

Freitas, Pedro de (1946) História da Música Popular em Portugal. Barreiro: Edição de Autor.

J. P. (1931), "Bandas Civis", Arte Musical 29: 5-6.

Pais, Guerra (1930) "Bandas de Música Civis Portuguesas", Arte Musical, 1: 5.

Ribeiro, Margarida (1971) "Relatório da Secção de Etnografia e Sociedades Recreativas". Trabalho apresentado no I Colóquio de Bandas Civis e de Filarmónicas. Santarém.

Silva, Romeu Pinto da (1977) "Programa de Apoio às Bandas", Informação Cultural, 2: 17-18. 
(Página deixada propositadamente em branco) 
Maria do Rosário Themudo Barata ${ }^{128}$

Universidade de Lisboa

\section{RELENDO KARL R. POPPER}

Um dos aspectos que me interessou particularmente na autobiografia intelectual de Karl Popper, cujo centenário se celebra este ano, foi o facto de, no discurso do pensamento, após o exame do processo de aprendizagem que caracteriza em três vertentes (no sentido do descobrimento ou formação dogmática de teorias, no sentido da aprendizagem por imitação e no sentido da aprendizagem por repetição ou prática, e que poderemos sintetizar em dois aspectos, a teorização e a crítica ou eliminação do erro), o filósofo sublinhar a importância que para ele revestiu a aproximação à Música.

Popper não acredita na aprendizagem por indução e defende que nunca existiu observação imparcial ou experiência passiva, pois que, como diz, há sempre o problema. Segundo as suas palavras, "a experiência é o resultado da exploração activa levada a cabo pelo organismo, da busca de regularidades ou invariantes", vincando que a hipótese deve ser prévia à observação e à percepção e que há expectações inatas, conhecimentos inatos latentes a serem activados por estímulos quando estamos comprometidos numa exploração activa. "Toda a aprendizagem é uma modificação (pode ser uma refutação) de algum conhecimento anterior, e assim, em última análise, de um conhecimento inato" (Karl R. Popper 1985: 69/70).

\footnotetext{
128 Em homenagem à Senhora Professora Doutora D. Maria Augusta Barbosa. Recordando, não só o magistério universitário que desenvolveu após o Doutoramento em Ciências Musicais na Alemanha - o primeiro doutoramento de um português nesta especialização - mas também a docência de História da Música no Conservatório Nacional de Lisboa. De ambas as circunstâncias a signatária preserva a riquíssima recordação do que usufruiu, pelo que as breves linhas que se seguem têm como propósito único o de manifestar o reconhecimento e a admiração por tudo o que deve à Homenageada. Páscoa de 2002.
} 
Estas posições não são de estranhar na filosofia essencialista e em todas as reflexões pós-kantianas, como também não surpreendem num retorno às matrizes do próprio pensamento grego, onde poderemos buscar as primeiras reflexões sobre a relação entre a música e o desenvolvimento do conhecimento. Mas hoje gostaria tão só de transmitir algumas reflexões acerca da comunicabilidade das artes.

Karl Popper refere o gosto pela música que era comum na família de sua mãe, a sua aprendizagem em tenros anos, a sua experiência como coralista na Paixão segundo S. Mateus de João Sebastião Bach, a amizade que o ligou desde sempre a Rudolf Serkin, bem como a Ernest Gombrich, ele, como sabemos, filho de uma aluna de Bruckner e casado com a pianista Ilse Heller e para quem o mundo das artes era um mundo multifacetado. Melhor dito, a Arte tem variadíssimos aspectos, qualia na expressão de Etienne Souriau, que se interrelacionam e se correspondem num mesmo processo de instauração.

Teremos de recordar que Viena de Áustria é, não só a sede do círculo lógico que marcou o século xx, mas uma das sedes europeias da música. Conservador no seu gosto musical, Popper inscreveu-se na Sociedade presidida por Arnold Schonberg, e que tinha como intenção divulgar a música contemporânea. Aí se familiarizou, não só com a música de Schonberg, mas também com a de Webern e de Alban Berg. E depois desta experiência voltou a dedicar atenção à música religiosa, também em Viena, e tornou-se cada vez mais admirador dos "clássicos".

Desse convívio musical colheu três princípios fundamentais que influenciaram, para sempre, as suas concepções (Karl R. Popper 1985: 73).

- as reflexões sobre o pensamento dogmático e crítico;

- a distinção entre o que considerou dois tipos de música, a música objectiva e a música subjectiva;

- a redução incomensurável que as ideias historicistas produzem na apreciação da música e das artes em geral.

Quanto ao primeiro ponto, o pensamento sobre a música levou-o a acentuar, mais do que a psicologia do descobrimento, a lógica do descobrimento, 
e a poder estudar não só a lógica do desenvolvimento da ciência grega, como a lógica da polifonia, ou seja, da harmonia musical ocidental. Neste sentido, a criação da música erudita ocidental é, para Popper, o facto mais original e milagroso da civilização ocidental, isto sem excluir a ciência: como, a partir de uma melodia, o coro humano desenvolveu o contraponto, em movimentos de vários sentidos mas num conjunto inter-relacionado, inventivo mas sem caos, e que é a característica da Harmonia.

A dogmática, a harmonia, a proposta científica terão em comum serem uma leitura que permite explorar a ordem dos mundos desconhecidos, criando regularidades e captando as já existentes. Qualquer destes exemplos fornece coordenadas. E, como diz, "além disso, uma grande obra de música (como uma grande teoria científica) é um cosmos imposto sobre o caos - nas suas tensões e harmonias inextinguíveis, inclusive para o seu criador" (Karl R. Popper 1985: 78).

Popper citava Kepler e falava nos pressupostos do conhecimento kantiano para sublinhar a logicidade do processo de conhecimento sobrepondo-se às considerações da psicologia do descobrimento.

A segunda questão dizia respeito ao que apontava como música subjectiva e música objectiva, o que mais tarde o leva a distinguir o Mundo 2 e o Mundo 3 na sua filosofia. Esta questão tinha começado por ser a tentativa de interpretar as diferenças entre a música de Bach e a música de Beethoven. Se bem que viesse, depois, a mitigar a diferença, não obstante não deixou de acreditar em que uma diferença essencial existia. Para Popper, Beethoven teria feito da música uma auto-expressão. Fidelio seria a mais emocionante expressão de fé de um homem, contra todo o desespero.

Isso não se passaria com João Sebastião Bach. Para além da apreciação das formas de criação artística dos dois grandes músicos, Karl Popper estabelecia uma apreciação global sobre a Arte em que não concordava, nem com a arte como produto do tempo e do lugar, nem com a arte como mera expressão ou auto-expressão do artista. Abordando, a este propósito, aspectos fundamentais de toda a estética e teoria da arte, Popper manifestava entender a Arte, não só como expressão subjectiva mas como referência (ao real ontologicamente falando) e como signo. A arte auto-expressão psicológica não lhe bastava. Havia a essencialidade da obra. O objectivo do 
verdadeiro artista seria, como o próprio diz, "a perfeição da obra” (Karl R. Popper 1985: 83).

Popper transmitia o que sentia no convívio com a obra musical de Bach: "Bach esquece-se de si próprio na sua obra, é um servidor da sua obra. Sem dúvida não deixa de imprimir a sua personalidade nela, isto é inevitável. Mas não era consciente às vezes, como era Beethoven, de que se estava exprimindo a si próprio e inclusive a seus humores. Por esta razão eu via cada um deles como representante de duas atitudes opostas com respeito à música" - e esta diferença poderia existir nas próprias peças religiosas dos dois compositores.

A questão seguinte seria a de saber se a estrutura de Bach é mais importante do que as rupturas dinâmicas e de que forma a música de Beethoven ou de outro compositor anota um comportamento diverso. Bach pretendia ensinar aos seus discípulos a composição, de forma clara e distinta, de maneira que os discípulos pudessem vir a desenvolver, mais tarde, as suas próprias ideias musicais. Onde caberia a emoção? Ela tem um lugar fundamental, e lembremos a profundíssima emoção da Paixão segundo S. Mateus, como inspiração e como julgamento, pelo próprio artista, da obra produzida. Mas essencialmente a música clássica ou erudita não é a que exprime as suas emoções em música, mas a que apresenta questões e problemas musicais, e os resolve.

E Popper voltava à questão já abordada: teria Beethoven sido o primeiro expressionista, porque compositor romântico?

Mas também a este propósito Karl Popper lembrava como Beethoven trabalhava, por vezes, versão atrás de versão, as suas ideias musicais (por exemplo, na Fantasia Coral e na Nona Sinfonia). E, na sua opinião, não fora o expressionismo a causa da decadência da música, mas a variedade de experiências formais desenvolvidas na época contemporânea, sem continuidade e sem sentido. Pois nada permite dizer que as artes progridem historicamente e que o progresso se dará quando um artista domina todos os conhecimentos do seu tempo.

Pode dar-se o caso de as novidades fazerem esquecer o adquirido, de as inovações formais não corresponderem à renovação da imaginação. Por isso, e estamos a focar o terceiro aspecto das reflexões de Popper, a visão historicista das artes será de banir, bem como a sobrevalorização dos aspectos 
de vanguarda. Alguns dos maiores artistas de todos os tempos não se preocuparam, nem procuraram, afirmar estilo próprio, ou moda. Bach, Mozart, Schubert, não pensaram nisso. Nem procuraram estar à moda. Portanto, o historicismo na Arte é um erro.

Estas observações de Karl Popper são estimulantes e oportunas. Antes de tudo o mais, no essencial, pelo que testemunham do enriquecimento intelectual que o convívio com a arte musical proporciona, colocando o debate das artes muito para além de emoções, modas, delírios de execução e de técnica, não rechaçando a emoção mas comprometendo-a com o entendimento, numa procura de sentido pleno e universal.

Seguindo os três passos do pensamento de Popper que referimos, no primeiro encontramos o sublinhado da lógica da invenção, segundo a qual melhor entenderemos a arte medieval, mas também a do tempo do classicismo e do barroco, sem cair na armadilha da dificuldade da distinção dos dois estilos, armadilha a que escaparam, entre outros, Victor Lucien Tapié e Pierre Chaunu que estudaram a época, a cultura e as artes, concluindo pela tensão lógica, intelectual e existencial da procura de ordem, sobrepondo-se aos estilos: o conteúdo dominando a forma, pois esta podia e devia ser dominada com toda a mestria. Se percebemos como artistas clássicos e barrocos coexistem na mesma época, pois lhes é comum algo de essencial para além do estilo diverso que adoptam, já há anos aprendíamos no Conservatório Nacional de Lisboa quão errado e incompleto seria classificarmos Bach "simplesmente" como compositor barroco: esqueceríamos a sua sabedoria de "ofício", a forma como desenvolveu a arte musical na senda das escolas de Viena e Mannheim, de seus mestres Reinken, Buxtehude, Pachelbel, escolas e mestres que tanto "explicam" Bach, como "explicarão" Haydn e Mozart, entre outros. Há a sequência lógica do desenvolvimento das ideias e das formas musicais, vocais e instrumentais, o labor continuado, a acção pedagógica que permitirá a liberdade do outro, numa procura universal de beleza, no aproveitamento da imaginação e das capacidades individuais, tendo como finalidade a obra. Afinal, não é ela, como diz Heidegger, o essencial?

A segunda reflexão é, também, extremamente interessante: a distinção entre música objectiva e música subjectiva. Certo é que o próprio Popper a matizou, pois, de outro modo, quereria parecer que desprezava em absoluto 
as diferenças culturais entre épocas e o próprio desenvolvimento das formas musicais, para não falar na inspiração e nos temperamentos; mas aqui poderíamos também aludir ao sentido diferencial que tem a palavra no emprego que dela fez Bach, por exemplo, no Cravo Bem Temperado. Estas reflexões sugeriram-me a necessidade de aludir ao trabalho de heurística e hermenêutica prévio a qualquer interpretação musical e quão necessário ele se patenteia quando se assiste a "fantasiosas" leituras e "intempestivas" execuções (mais sensível, o erro já foi corrigido nas interpretações de Chopin e Debussy, mas o perigo espreita qualquer um. E não falo na música para vozes). Cabe ao intérprete, na arte musical, como no teatro e na dança, dar corpo à obra. E como se complexifica a questão da execução! Cabe ao intérprete dar a versão do autor, ou a sua própria? Qual a relação do artista e da obra?

Este aspecto relaciona-se com o terceiro: o papel da técnica no desenvolvimento das artes, a importância do domínio das técnicas específicas de cada arte. O domínio do quadro técnico específico é essencial para cada artista. Já assim os artistas do renascimento e do maneirismo consideravam, mas estes últimos pensaram poder garantir, com este aspecto, a perenidade da qualidade estética e do estilo, e enganaram-se pois lhes faltou a consciência da historicidade de que outros abusam. A Arte procura o Eterno sob formas mutáveis, seguirá o seu caminho próprio e não se confundirá com a Filosofia, onde terminaria. Mas também não se confundirá com a História e com os recursos do tempo e do lugar. A qualidade da execução das Sonatas de Beethoven não residirá, apenas ou principalmente, na rapidez dos Allegro ou noutras capacidades técnicas do executante. Se bem que o verismo tenha os seus perigos, a ausência do referencial ao tempo e ao lugar da criação artística é outro logro. E antes de qualquer "execução" há que compreender o mais completamente possível o projecto do autor.

Ora, para isso há que conhecer a forma. Tanto na música como nas artes em geral, apesar dos excessos criticados ao formalismo, há noções fundamentais de Forma a preservar, e, no campo musical, ideias melódicas e opções harmónicas a desenvolver logicamente e a completar. A apreciação das artes não se poderá resolver tão só pela filosofia nem só pela historcidade, mas pela busca da essência do problema e da arte que é, ela mesma problema, como manifestação e "des-ocultação" do Ser. A historicidade não explica a 
melhoria das artes, da mesma forma como a Arte não deverá aceitar qualquer compromisso que represente um reducionismo em relação à sua essência e finalidade. Afinal, atingir o Ser e o Universal. E, como concluiria o Hípias, eis o que é difícil.

\section{Bibliografia}

Karl R. Popper (1985) Búsqueda sin término. Una autobiografia intelectual, Trad. do original de 1974 de Carmen Garcia Trevijano, $1^{\text {a }}$ ed. 1977, $1^{\text {a }}$ reimp. 1985, Madrid, Editorial Tecnos, S.A. 
(Página deixada propositadamente em branco) 
Mário Vieira de Carvalho

Universidade Nova de Lisboa

\section{A INVESTIGAÇÃO EM MÚSICA NO ENSINO SUPERIOR ${ }^{129}$}

Em 2001 publiquei na Revista da Faculdade de Ciências Sociais e Humanas um extenso artigo, intitulado "As ciências musicais na transição de paradigma", no qual procedia a uma reflexão crítica retrospectiva sobre as ciências musicais e as suas diferentes sistematizações. Retomo aqui apenas algumas ideias desse texto, como introdução às questões que vos quero colocar.

A investigação em música não se esgota na musicologia ou nas ciências musicais, mas parece-me incontornável começar por discutir o momento fundador que está na origem da sua organização no ensino superior. Refiro-me à Universidade de Viena e à sistematização das Ciências Musicais por Guido Adler.

Em 1885, Adler partia da dicotomia clássica entre ciência histórica e ciência sistemática tomada a outras disciplinas (designadamente às ciências jurídicas, que lhe eram familiares). A perspectiva da história (ou diacrónica) baseava-se no método ideográfico; a perspectiva das ciências da natureza (sincrónica) baseava-se no médodo nomológico. Aquela debruçava-se sobre o peculiar, o singular, o evento situado no tempo e no espaço (o «acontecimento histórico»). Esta ocupava-se (em regra) do repetível, do ocorrente segundo determinadas leis, do mensurável (cf. Karbusicky, 1979: 17).

No enunciado de Adler, a musicologia como ciência histórica tinha por objecto a história $d a$ música «segundo as épocas, povos, impérios, nações, regiões, escolas artísticas, artistas». Enquanto ciência sistemática, visava «o estabelecimento das leis supremas que regem os ramos singulares da arte dos sons [Tonkunst]».

129 Comunicação ao Encontro Nacional de Investigação em Música, Porto, Casa da Música, 25-27 de Novembro de 2011. 
A sistematização de Adler reflectia, naturalmente, o paradigma da ciência moderna, o seu ponto de vista universalista e fundado numa epistemologia pretensamente imune ao senso comum. Mas hoje salta imediatamente à vista o seu carácter local.

A visão científica de Adler decorria do seu mundo musical: o mundo da música germânica e, especialmente vienense, desde o fim do século xviII. Importa enfatizar a distinção subtil que ele fazia entre, por um lado, a música, objecto da abordagem histórica e, por outro, a arte dos sons, objecto da abordagem sistemática. Eis aqui uma hierarquia implícita, que já tinha sido antes acolhida por Hegel e Hanslick. Se a tivermos em conta, então percebemos melhor o «sistema» de Adler:

- o objecto da musicologia histórica era a narrativa diacrónica da transformação da música em «arte dos sons»;

- apurada a «arte dos sons» (Tonkunst), competia à musicologia sistemática enunciar as "leis supremas" que a regiam (leis, em rigor, atemporais e universais, não relativizadas ou relativizáveis contextualmente).

A Tonkunst (isto é, a arte musical germânica e vienense da modernidade vivida por Adler) aparecia pois aqui como telos da música (Riethmüller, 1985: 71). A história captava a progressão da música até ao estádio de "arte dos sons", isto é, ao estádio em que era possível passar ao "enunciado das leis supremas do belo", que era objecto da Estética como disciplina sistemática.

Esta narrativa diacrónica era completada pela narrativa sincrónica que permitia distinguir a "arte dos sons» de outros fenómenos ou práticas musicais europeus ou extra-europeus que com ela coexistiam no presente. Tal era o objecto da disciplina sistemática a que Adler chamava Musikologie, que deu origem à Vergleichende Musikwissenschaft e depois à Etnomusicologia.

Finalmente, havia que transformar as «leis supremas do belo» nos enunciados normativos da pedagogia e da didáctica, também disciplinas sistemáticas, assegurando ad aeternum a reprodução "do belo musical».

O sistema não podia ser mais coerente e perfeito. O problema é que, justamente na altura em que Adler o gizava, já o movimento da história o punha 
fortemente em causa. A relação entre «teoria» e sua "aplicação» prática começara a ser abalada pelo processo de dissolução do sistema tonal. Por volta de 1900 estabelecia-se, também na música, a «institucionalização da anomia", com antecedentes na arte europeia desde meados do século xıx (Bourdieu, 1987: 255ss.). A «transvaloração de todos os valores» (Umwertung aller Werte), na formulação de Nietzsche, atingia, aliás, a sociedade e as estratégias de vida no seu todo. Uma estética normativa tornara-se inviável.

Não admira, por isso, que outras sistematizações se tivessem seguido às de Adler e que a noção de historicidade na abordagem da música ganhasse terreno. Contudo, em 1971, Carl Dalhaus ainda sentia a necessidade de propor a superação da fronteira rígida entre a perspectiva histórica e a sistemática, bem como, do mesmo passo, a distinção entre método ideográfico e método nomológico. Para Dahlhaus, "a verdadeira contrapartida da história da música» era representada por ciências como a psicologia da música, a teoria da música e a sociologia da música». Estas seriam uma espécie de disciplinas intermédias, de charneira, cujo método nem era nomológico, nem ideográfico. (Dahlhaus, 1971: 128).

Ainda assim, num artigo publicado na International Review of Aesthetics and Sociology of Music, fundada em 1970 pelo musicólogo croata Ivo Supicic, o mesmo Dahlhaus contestava a possibilidade de «a obra de arte musical» poder ser objecto da sociologia da música. Ou seja: apesar de reconhecer a necessidade de superação da sistematização de Adler, o próprio Dahlhaus permanecia arreigado a um dos princípios que a tinham inspirado: a distinção de base entre o que era arte e o que não era arte. Princípio que continuaria a marcar o ensino e a investigação musicológicas.

Superado o mito das «leis supremas do belo», o interesse pela abordagem histórica da criação musical europeia passara a predominar em absoluto, como Karbusicky (1979) verificou no estudo comparativo que empreendeu sobre os curricula universitários na década de 70. A «história da música» ou «musicologia histórica» tornara-se a ciência musical por excelência, empurrando as outras disciplinas para a marginalidade.

Entretanto, a distinção entre o estudo da "arte dos sons» europeia, reservado à musicologia histórica, e o estudo das culturas musicais tradicionais e/ou extra-europeias, reservado à etnomusicologia, traduzia-se na separação 
dos respectivos curricula e institutos de ensino e investigação, em mundos académicos isolados um do outro. Como já tenho referido noutras ocasiões, dir-se-ia que a etnomusicologia - e, portanto, a abordagem sociológica ou antropológica - era quase exclusivamente reservada ao estudo do "Outro inferior»: aquele que ainda não acedera supostamente nem ao conhecimento científico, nem à maturidade artística.

No meu texto de 2001 já mencionado, chamei também a atenção para a crítica pioneira de Charles Seeger (1935, 1951), uma das mais consequentes no diagnóstico das dificuldades legadas pelo sistema de Adler. A sua visão surpreende pelo engenho com que procura combinar três entrecruzamentos distintos no estudo da música:

1 entrecruzamento de dois pontos de vista: o "ponto de vista musical» propriamente dito e o "ponto de vista geral» ("não musical» ou "extra-musical»);

2 entrecruzamento de duas orientações: a «orientação sistemática» e a "orientação histórica»;

3 entrecruzamento de dois métodos: o «método científico» e o «método crítico».

Seeger (ao contrário de Adler) não estabelecia um elenco de disciplinas, mas postulava dir-se-ia o mais largo espectro de interdisciplinaridade possível a partir destes entrecruzamentos "que devia servir de base para a descrição de qualquer música com o máximo de objectividade».

No entanto, a preocupação de sistematizar era por ele tão longe levada, a sua visão sistemática totalizante era de tal modo ambiciosa, que as operações previstas no seu apparatus acabavam por rigidificar paradoxalmente as fronteiras entre o «musical» e o "extra-musical», entre o "histórico» e o "sistemático".

Numa aproximação ulterior ao problema, incluída na sua colectânea de ensaios publicada em 1977, Seeger (1970: 108) procurou aperfeiçoar a sua tentativa "de definição abrangente», isto é "totalizante» da musicologia. Passou a falar então de seis universos:

1 A musicologia era um estudo discursivo [a speech study], ao mesmo tempo sistemático e histórico, crítico e científico; 
2 O campo da musicologia era "a música total do ser humano, tanto em si mesma como nas suas relações com o que ela não era em si mesma»;

3 O exercício da musicologia cabia a estudiosos individuais, que podiam ver o campo dela, ou como músicos, ou como especialistas não musicais dentro de cujos campos alguns aspectos da música eram considerados como factos dados;

4 O objectivo da musicologia era a compreensão do ser humano, quer enquanto cultura humana...

5 ...quer na relação do ser humano com o universo físico.

A estes cinco "universos", cada um dos quais, inter-relacionado com todos os outros, juntava-se um sexto:

6 O universo do valor [value], conceito estrutural que consistia em operações de avaliação recíproca entre os diferentes universos. As conexões entre estes não eram apenas factuais, decorriam também de estratégias de avaliação. O discurso era a instância de integração de "facto" e "valor» (Seeger, 1970: 118 ss.).

Mais importante do que a pretensão totalizante da sistematização de Seeger e, de certo modo, em contra-ciclo com a mesma, é, porém, uma nova dimensão que ele introduz: a de questionar a musicologia como "prática para si». Ou seja, Seeger já parece partilhar de uma atitude de hermenêutica crítica da epistemologia, no sentido precisado por Boaventura Sousa Santos (1989: 28 ss.): o de responder à crise do paradigma da ciência moderna com o princípio geral de que «o objectivo existencial da ciência está fora dela»: é o humano.

Contudo, mesmo na reformulação dos anos 70, Seeger continua a não contemplar, por exemplo, a relevância intramusical do social como objecto da musicologia. A noção de «universo» inter-relacionável com outros «universos» não andava longe, porém, da tentativa de Kluge e Kaden, nos finais da década de 70, de superar a oposição entre orientação histórica e orientação sistemática através duma abordagem sistémica aberta, que põe em evidência as conexões estruturais entre diferentes áreas do social e do humano na sua 
interacção com os processos naturais (cf. Kluge 1977; Kaden, 1984, 1987). "Sistema» é entendido aqui, não como um conceito oposto ao de evolução ou desenrolar no tempo, mas sim como unidade de estrutura e processo, a qual não é resultado da mera cooperação ideal entre dois tipos de abordagem, antes é qualidade ou propriedade material dos fenómenos abordados. De "process-based systems thinking» como desafio aos limites da noção de estrutura, válido para os mais diversos campos científicos, falam nomeadamente Edwards e Jaros num artigo de 1994. Capra sublinha, por sua vez, em 1996, a relevância crescente do conceito de web of life ou networking nas ciências da natureza, porventura o contributo mais influente e de maior alcance do legado de Darwin, que se tornou mutatis, mutandis, não menos relevante para as ciências sociais. Web e networking são realidades que não podemos ignorar num mundo globalizado, onde todos se encontram conectados uns com os outros também via internet. "O real é relacional» - já o diziam Hegel e Bourdieu.

Podia citar ainda no mesmo sentido Joseph Kerman (1985), quando fez um historial das aporias em que se têm enredado diferentes escolas e tendências, designadamente nas áreas da história e da análise musicais, precisamente por não reconhecerem, à partida, a interdependência de factores e processos que a construção do objecto segundo esse modelo relacional poderia ajudar a surpreender e clarificar. Lembro, a propósito, que Kerman (ibid.: 73), compara a operação dos analistas que «removem a partitura, isolada, do seu contexto em ordem a examiná-la como um organismo autónomo" à operação que "remove um organismo da ecologia que o sustém». Noutro passo, Kerman (1985: 164), em crítica à tradição da musicologia histórica, conclui que «a famosa definição de Merriam» segundo a qual a etnomusicologia é "o estudo da música na cultura" tem o mérito de esclarecer o que o estudo da música não é: «não é o estudo da música ou músicas como estruturas ou sistemas autónomos». Neste sentido, critica Nattiez e outros que buscam a significação na imanência do texto, em vez de a procurarem na sua relação com as práticas sociais - aí convergindo com a viragem pós-estruturalista, na esteira de Wittgenstein, que acentuava o contexto dos usos da língua na significação. (Sobre essa viragem e as suas consequências para o estudo das artes em geral merece ser lembrado aqui um artigo de Anthony Giddens [1987]).

O pressuposto de que Kerman já partia era o da superação da dicotomia entre música e sociedade, já que também os processos musicais são 
necessariamente processos sociais. Nesse sentido, Adorno está mais perto de Merriam do que parece, na medida em que chama a atenção para a natureza social do material. Escalas, instrumentos, formas, técnicas de composição não são dados da natureza nem existem fora da sociedade. O material com que o músico trabalha é social e historicamente pré-formado. Por isso, para Adorno, a abordagem filosófica da obra é, simultaneamente, uma abordagem sociológica. Filosofia e sociologia tornam-se indestrinçáveis uma da outra. Eis o que se prende com o próprio conceito de teoria crítica.

A sociologia da música de Adorno incide tanto sobre a obra musical em si como sobre os contextos da criação, interpretação e recepção. Mas, em Adorno, a crítica da ideologia tem de ser uma crítica da linguagem. E a crítica da linguagem remete para a crítica da própria linguagem científica.

E eis como regressamos ao ponto de partida: o da crítica do cânone, o da necessidade de qualquer discurso científico se colocar a si próprio em questão, tal como é preconizado, em especial, para as ciências sociais por Immanuel Wallerstein, no relatório Para Abrir as Ciências Sociais (1996) que lhe foi encomendado pela Fundação Gulbenkian.

Devo a esta obra de Wallerstein o impulso para a posição que defendi no ano seguinte, em 1997, na mesa redonda sobre Musicologia e Sociologia realizada no âmbito do XVI Congresso da Sociedade Internacional de Musicologia, em Londres, subordinado ao tema "A musicologia e as disciplinas irmãs» (as comunicações das mesas-redondas foram recolhidas e publicadas por David Greer na Oxford University Press em 2000). Apontei então como principal tarefa da Sociologia da Música a de se constituir como uma "musicologia auto-crítica» ("Sociology of Music as Self-Critical Musicology») (Vieira de Carvalho, 2000). Isto é, defendi e defendo que a sociologia da música - em diálogo aberto com diferentes correntes do pensamento contemporâneo - tem de começar por questionar criticamente o conhecimento musicológico, incluindo o dela própria como disciplina científica.

Problematizar o discurso científico é colocar em questão tanto a tradição da musicologia histórica como a da etnomusicologia. Quanto à musicologia histórica, importa questionar a ideologia da objectividade que nela ainda está instalada e continua a servir de bandeira mesmo aos investigadores mais jovens - objectividade entendida como conhecimento da música em 
si, a partir de uma perspectiva em que o investigador é suposto ser imune a contextos de espaço e de tempo, à política e às ideologias ("o acto político de despolitizar a música", e também a de a "disciplinar», para citar Bohlman [1993]). Quanto à etnomusicologia, o bloqueio tende (ou tendia) a ser para a reificação da metodologia - a crença num método que se crê adequado a qualquer situação ou processo musicais e que permitiria assegurar a posição neutral do investigador.

Ao problematizar a objectividade, como Wallerstein observa no seu relatório, não se trata de reduzir as ciências sociais "a uma miscelânea de perspectivas individuais", mas sim de submeter a investigação "ao juízo intersubjectivo" - excluindo, portanto, que qualquer dos interlocutores se sirva da «máscara da objectividade para levar por diante a sua visão subjectiva». "Empurrar" as ciências sociais "na direcção de um significativo grau de objectividade» consistiria, pois, segundo Wallerstein, em levá-las a adoptar "uma postura de inclusão (no que respeita ao recrutamento dos seus praticantes, à abertura a uma multiplicidade de experiências culturais, ao leque dos tópicos de estudo julgados legítimos)» e a privilegiar uma posição auto-reflexiva crítica: ter consciência de que "o conhecimento é socialmente construído" é o primeiro passo para produzir socialmente um conhecimento mais válido» (ibid.: 129s.).

Relativamente à problematização do método, os Elementos Filosóficos de uma Teoria da Sociedade de Adorno, publicados postumamente em 2008, nada perderam da sua actualidade. Adorno denuncia aí a "fetichização do conhecimento", que consiste em colocar o método no lugar da finalidade do conhecimento, isto é, levando a uma inversão dos meios e dos fins. Em alternativa à tendência para aperfeiçoar o método como se nada tivesse a ver com o objecto, propõe que se refinem os instrumentos científicos, agudizem os critérios, pondo à prova a validade das proposições científicas, na qual necessariamente intervém o próprio objecto estudado. Opõe ao pensamento dedutivo cartesiano, o pensamento indutivo de Bacon (Novum Organum, 1620), que já postulava a necessidade de questionar os critérios como “ídolos» enganadores que excluem como impossível aquilo que é ou pode ser parte do real. O problema epistemológico decisivo, para Adorno, está, portanto, na resistência da realidade à teoria. Daí a sua crítica à concentração no método, 
que impede a compreensão do objecto. ${ }^{130}$ Assim, em oposição ao mito da absoluta correcção da metodologia, que fetichiza a ciência e esteriliza o conhecimento crítico, Adorno reconhece que é, não raro, mais produtiva a abordagem imediata do objecto, a recuperação da espontaneidade naïve.

Trata-se de recuperar a capacidade de experiência não regulamentada e cultivar o achado ou a inspiração (Einfall), a espontaneidade, tal como na arte. Cultivar o achado ou a inspiração não invalida, contudo, a necessidade de os pôr à prova e submeter ao controlo da adequação ao objecto. O método carece de auto-problematização crítica, requerida pela própria necessidade de compreender o objecto. É necessária a mediação recíproca entre o conceito e a diversidade da experiência sensível.

Mas é ainda Adorno que me leva à última questão, antes de retirar de tudo isto algumas conclusões eventualmente úteis. Essa última questão é a da arte em si, ou da música em si, ela própria como conhecimento, como via de conhecimento autónomo, diferente do conhecimento científico. À força de querermos estudar e compreender a música submetendo-a à abordagem de um leque pluridisciplinar muito variado que vai desde a sua consideração como fenómeno físico-acústico à sua consideração como praxis social, passando por muitas outras dimensões (psicológicas, cognitivas, histórico-antropológicas, estéticas, etc., etc.), corremos o risco de subestimar o que ela própria nos pode proporcionar como actividade de conhecimento, isto é:

- não se trata apenas de compreender a música através da história, mas também de compreender a história através da música;

- não se trata de pensar a música na perspectiva da filosofia, mas também de abordar a música ela própria como filosofia;

- não se trata de interpretar a música segundo um quadro teórico-metodológico das ciências sociais, mas também de ela nos interpretar a nós e à

130 Para Adorno, é neste mesmo princípio que assenta o fundamento das nossas sociedades. Abstrai-se das qualidades e dos valores de uso específicos que as coisas em si tomam no seu relacionamento com as pessoas. Tudo é reduzido à forma de equivalência geral - ao valor de troca, um princípio de valor abstracto, separado do próprio objecto, princípio que, afirma ele, é replicado na ciência e na filosofia. Domina a razão instrumental ou a instrumentalização da razão. 
sociedade em que vivemos (como se a música também pudesse ser uma espécie de teoria social codificada em sons).

Ou seja: é preciso que a música não seja apenas objecto de conhecimento, mas também sujeito activo de conhecimento. Eis o que se procura contemplar hoje em dia na chamada "artistic research", conhecimento através das artes, da prática artística, daquilo que só estas podem proporcionar como abordagem do humano e do real, algo que não é comensurável ou traduzível em palavras ou pensamento discursivo.

Que poderíamos retirar daqui para a organização ou reorganização da investigação em música no ensino superior? Eis os pontos que ponho à discussão:

1 Abandonar de vez a ideia de um currículo de disciplinas fechado ou demasiado centrado num núcleo duro de disciplinas obrigatórias. Em cada estabelecimento de ensino superior, não se trata de clonar diplomados, mas sim de abrir as portas a perfis individuais de formação diferenciados.

2 Abandonar as grandes narrativas lineares que, na ânsia de preencherem todas as possíveis lacunas na transmissão de conhecimento, não fazem senão reduzi-lo a um conhecimento canónico, que exclui mais do que integra. Em cada área do saber o conhecimento totalizante é ilusório. Assumir a abordagem do fragmento, o estudo de caso, o problema ou o tópico específicos, a questão ou a pergunta a que pretendemos responder com um seminário - eis o que me parece mais produtivo para a formação dos estudantes, estimulando do mesmo passo a ligação entre ensino e investigação. Com os recursos hoje disponíveis via internet, menos ainda se justificam as grandes narrativas.

3 Em vez de predeterminar linhas de especialização mais ou menos compartimentadas, antes favorecer a sua emergência e diferenciação através da ars combinatoria de módulos ou unidades de formação. Não reduzir as ciências musicais (como até aqui, por exemplo, na FCSH) à pseudo-dicotomia entre "musicologia histórica» e "etnomusicologia», quando a Filosofia e a Estética musicais, a Sociologia da Música, a Psicologia e a Psicopedagogia musicais, 
os Estudos Cognitivos, os Estudos de Música Popular, de Globalização, Mass Media, Estudos Culturais, Estudos de Género, a chamada Investigação Artística ou Artistic Research (envolvendo não só Estudos de Composição e Performance, mas também as relações da música com a literatura e as outras artes), Música e Política, etc. etc. são igualmente susceptíveis de mobilizar recursos docentes e o empenho dos estudantes.

4 Acabar com os compartimentos estanques entre a via de formação artística e a via da formação musicológica. Promover a possibilidade de interpenetração de ambas.

5 Não coarctar drasticamente, como tem acontecido, as possibilidades de formação em áreas do conhecimento diferentes da música ou da musicologia como áreas principais. Favorecer a dinâmica dos majors e dos minors, permitindo muito maior peso da formação que pode ser obtida fora da área principal. Se não queremos formar músicos ou musicólogos que sejam clones uns dos outros, também não queremos que eles, ainda por cima, corram o risco de vir a ser Fachidioten (como dizem os alemães: especialistas idiotas). ${ }^{131}$ Mais interdisciplinaridade na formação não retira competências ao especialista na área principal. Pelo contrário, reforça-as. Um musicólogo que tenha uma forte componente em sociologia, ou em filosofia, ou em economia, ou em psicologia, ou em direito, ou em literatura, ou em cinema, ou em arquitectura, ou em engenharia, ou em biologia, etc., etc., obtida à custa de disciplinas de música/musicologia que tivesse de frequentar num currículo maximalista, não perde competências musicais/musicológicas, antes pelo contrário: fecunda-as, alarga-as, reforça-as. O cruzamento interdisciplinar permite-lhe apreender e reformular os problemas da música/musicologia sob uma nova perspectiva. Está mais apto a produzir conhecimento novo, em vez de reproduzir mais do mesmo. Está mais alerta relativamente à inércia do saber, que Bourdieu exprimiu num dito corrente no "Direito das Sucessões»: le mort saisit le vif (o morto toma conta do vivo que lhe aceita a herança).

131 Hoje há povos inteiros a sofrer na pele o erro de formar Fachidioten na economia. 
6 Opções científicas quanto às disciplinas a considerar são neste, sentido, opções ideológicas. Uma perspectiva inclusiva torna tão legítimo um seminário de "Música e Política» quanto um seminário sobre "Música barroca». Comecemos por não fazer da nossa própria disciplina a mais importante de todas, e pretender torná-la obrigatória. Temos de abandonar este pensamento. Há que definir, sim, módulos de formação, cada qual com um número variável de seminários, dentro dos quais o estudante deverá obter unidades de crédito. E depois deixar que o estudante combine esses módulos de acordo com as suas motivações e interesses, ora tomando a música/musicologia como área principal, ora como área complementar ou minor, e possa ir buscar as unidades de crédito restantes a módulos de outras áreas disciplinares. Na minha opinião, nenhuma licenciatura devia ter mais de 120 unidades de créditos em módulos relativos à área principal (2/3 do total). O restante terço devia poder ser consagrado pelo estudante a módulos de outras áreas (até 60 u. c.). Também nos mestrados a abertura interdisciplinar devia ser assegurada. E os próprios mestrados serem já, de raíz, diversificados: reflectindo o vasto leque de abordagens possíveis da música/musicologia.

7 O conceito que melhor define esta proposta de organização curricular é o conceito de rede: rede de possibilidades de formação, que deve ser oferecida aos estudantes que entram no ensino superior. Eles entram para uma escola, para um curso ou área de formação principal, mas devem ter à sua frente várias combinações em aberto, dentro e fora dessa escola, dentro e fora do país. E essa abertura não deve parar no primeiro grau. O segundo grau deve abrir ainda mais o leque das alternativas. O percurso curricular de cada estudante, em vez de pré-dado, tornar-se-á um processo emergente, a partir dessa rede de possibilidades de formação. 


\section{Referências}

Adler, Guido (1885), «Umfang, Methode und Ziel der Musikwissenschaft», Vierteljabrschrift für Musikwissenschaft, I, 1 (1885): 5-20.

Adorno, Theodor W. (2008), Philosophische Elemente eine Theorie der Gesellschaft (eds. Tobias ten Brink and Marc Phillip Nogueira), Frankfurt a.M.: Suhrkamp, 2008.

Bohlman, Philip V. (1993), "Musicology as a Political Act», in: The Journal of Musicology, XI/ 4 (1993): 411-436.

Bourdieu, Pierre (1987), O Poder Simbólico, Lisboa, Difel, 1989.

Capra, Fritjof (1996), The Web of Life. A New Scientific Understanding of Living Systems, New York: Anchor Books.

Dahlhaus, Carl (1974a), "Das musikalische Kunstwerk als Gegenstand der Soziologie», International Review of the Aesthetics and Sociology of Music, V (1974): 11-24.

Edwards, Lynn B., e Gyorgy G. Jaros (1994), «Processe-Based Systems Thinking Challenging the Boundaries of Structure", Journal of Social and Evolutionary Systems, 17/3 (1994): 339-353.

Giddens, Anthony (1987), "Structuralism, post-structuralism and the production of culture», Social Theory and Modern Sociology (do mesmo), Londres, Blackwell, 1993: 73-108.

Kaden, Christian (1984), Musiksoziologie, Berlin, Verlag Neue Musik.

Kaden, Christian (1987), «Systematische Musikwissenschaft» [entrada elaborada para uma nova edição remodelada do Dicionário de Música de Tomás Borba e F. Lopes--Graça, segundo uma concepção depois abandonada com a demissão do coordenador do projecto, Mário Vieira de Carvalho], ms.

Karbusicky, Vladimir (1979), Systematische Musikwissenschaft. Eine Einführung in Grundbegriffe, Methoden und Arbeitstechniken, Munique, Wilhelm Fink.

Kerman, Joseph (1985), Contemplating Music. Challenges to Musicology, Cambridge/ Massachusetts, Harvard University Press.

Kluge, Reiner (1977), "Auf dem Weg zu einer Systematischen Musikwissenschaft", Beiträge zur Musikwissenschaft, XIX (1977), 4: 3-16.

Merriam, Alan P. (1964), The Anthropology of Music, Evanston, Northwestern University Press.

Riethmüller, Albrecht (1985), «Stationen des Begriffs Musik», Geschichte der Musiktheorie, I (ed. Frieder Zaminer), Darmstadt, Wissenschaftliche Buchgesellschaft.

Seeger, Charles (1935), "Systematic and historical orientations in musicology", Acta Musicologica, XI (1939): 127-128.

Seeger, Charles (1951), "Systematic Musicology: Viewpoints, Orientations, and Methods», Journal of the American Musicological Society, IV, 3 (1951), 242-243. 
Seeger, Charles (1970), "Toward a Unitary Field Theory for Musicology", Studies in Musicology (1935-1975) (do mesmo), Berkeley, etc., University of California Press, 1977: 102-138.

Seeger, Charles (1977), "Systematic (synchronic) and historical (diachronic) orientations in Musicology", Studies in Musicology (1935-1975) (do mesmo), Berkeley, etc., University of California Press, 1977 : 1-15.

Sousa Santos, Boaventura de (1989), Introdução a uma Ciência Pós-Moderna, Porto, Afrontamento.

Vieira de Carvalho, Mário (2000) "Sociology of Music as Self-Critical Musicology", in: Musicology and Sister Disciplines - Past, Present, Future(ed. David Greer), Oxford, Oxford University Press, 2000: 342-366.

Vieira de Carvalho, Mário (2001), "As ciências musicais na transição de paradigma", in: Revista da Faculdade de Ciências Sociais e Humanas, 14 (2001): 211-233.

Wallerstein et al., Immanuel (1996), Para abrir as ciências sociais. Relatório da Comissão Gulbenkain sobre a reestruturação das Ciências Sociais, Lisboa, Europa-América. 
Salwa El-Shawan Castelo-Branco

Universidade Nova de Lisboa

\section{A ETNOMUSICOLOGIA NA UNIVERSIDADE NOVA DE LISBOA: OS PRIMEIROS ANOS}

\section{Introdução}

A professora Maria Augusta Barbosa fundou o curso de Licenciatura em Ciências Musicais (LCM) na Faculdade de Ciências Sociais e Humanas (FCSH) da Universidade Nova de Lisboa, em 1980, institucionalizando o estudo científico da música no ensino universitário em Portugal. Embora tenha dirigido o Departamento de Ciências Musicais (DCM) que enquadra a LCM durante um período curto (1980-1983), deixou uma marca indelével no ensino da musicologia em Portugal, pela configuração do programa de Licenciatura, ancorada na sistematização do objecto da investigação musicológica proposta por Guido Adler em 1885 (Mugglestone 1981), que também enformou a investigação e o ensino da musicologia em diversas universidades na Europa e nos Estados Unidos de América ao longo do século xx, pela selecção criteriosa do corpo docente inicial, e pela seriedade, rigor e dedicação que imprimiu ao seu trabalho, inspirando todos que com ela colaboraram. A partir de 1983, após a aposentação da professora Maria Augusta Barbosa e ao longo de cinco anos, e novamente entre 1995 a 1997, tive o prazer e a honra de ser coordenadora do DCM, desenvolvendo o trabalho que ela havia iniciado.

Este texto em homenagem à Professora Maria Augusta Barbosa é um testemunho pessoal, ancorado na minha memória, naturalmente fragmentada e selectiva, dos primeiros anos da institucionalização da Etnomusicologia no âmbito da LCM na FCSH. Enquadra-se na abordagem etnomusicológica ao estudo do passado (Bohlman 2008, Shelemay 1980) e na perspectiva lançada 
pela Antropologia pós-moderna em meados da década de 80 (Clifford \& Marcus 1986) e adoptada pela Etnomusicologia na década seguinte que realça a importância da reflexividade, do dialogismo e da multi-vocalidade na escrita etnográfica, atribuindo ao etnógrafo os papeis de observador, intérprete, "escrivão" e "arquivista" das realidades que vivenciou e que constituem o seu objecto de estudo (Clifford 1986: 1-26).

\section{O primeiro encontro: verão de 1981}

O meu primeiro encontro com a professora Maria Augusta Barbosa teve lugar no início do verão de 1981. Na altura desempenhava o cargo de professora auxiliar de Etnomusicologia na New York University e de coordenadora do Mestrado em Etnomusicologia urbana que tinha lançado aquando da minha contratação naquela universidade, em 1979. Estava de visita a Portugal com meu marido, Gustavo Castelo-Branco, estando ambos a considerar a possibilidade de prosseguirmos as nossas carreiras académicas em Portugal.

A FCSH, fundada em 1977, funcionava nas instalações da antiga Direcção de Recrutamento Militar na Ave. de Berna, num conjunto de edifícios antigos de dois pisos adaptados para salas de aula e gabinetes. O DCM ocupava uma sala de aulas e um gabinete partilhado por todos os professores e pela professora Maria Augusta Barbosa no segundo andar de um dos edifícios.

O primeiro encontro com a professora foi marcante. As suas qualidades humanas e profissionais eram evidentes. No seu discurso enérgico, determinado e optimista, transparecia a complexidade da sua missão: estabelecer um novo domínio científico no meio académico Português, configurar um programa de Licenciatura de qualidade, assegurar um corpo docente competente e empenhado, ganhar apoios dentro e fora da universidade, atrair alunos qualificados para o novo curso. Outros desafios eram comuns a toda a FCSH, afectando também o DCM: melhorar, alargar e equipar as instalações, disponibilizar recursos bibliográficos e discográficos, assegurar a cobertura docente com professores qualificados.

Recebeu-me com grande cordialidade, manifestando interesse no meu percurso académico. Inteirou-me do currículo do DCM, dos seus objectivos e do elenco de professores que já o integrava, partilhando a sua preocupação 
com o facto de que na altura, mais de metade das cadeiras estavam sem cobertura docente por falta de professores qualificados. Na altura o corpo docente era constituído por personalidades destacadas no meio musical e cultural português, alguns dos quais foram docentes, ou continuaram a leccionar noutras instituições de ensino da música em Portugal ou no estrangeiro, nomeadamente os professores Gerhard Doderer (musicólogo e organista), João de Freitas Branco (musicólogo, critico e gestor cultural), Constança Capdeville (compositora, intérprete e pedagoga), João Ranita Nazaré (musicólogo e sociólogo) e a própria professora Maria Augusta Barbosa. ${ }^{132}$ Discutimos a oferta da Etnomusicologia, tendo a professora manifestado interesse em integrar, no programa da LCM, cadeiras em torno de culturas musicais extra-europeias e da abordagem teórica e metodológica da moderna Etnomusicologia. ${ }^{133}$

$A$ abertura de MAB às perspectivas da moderna Etnomusicologia que partilhei com ela logo no nosso primeiro encontro, a sua ambição para o DCM e a sua vontade de vencer o grande desafio a que se propunha deixaram-me entusiasmada com a perspectiva de contribuir para a institucionalização da disciplina em Portugal, um país com uma tradição de colecta de música de matriz rural por parte de etnógrafos e folcloristas, mas onde a moderna Etnomusicologia era até então desconhecida. ${ }^{134}$

\section{O ano lectivo de 1982-1983}

Volvido um ano, regressei a Portugal como "Professora Associada Convidada" a convite da FCSH, por iniciativa da professora Maria Augusta Barbosa,

132 Uma síntese do percurso biográfico, académico ou artístico assim como uma breve análise e listagem da obra literária ou musical de Maria Augusta Barbosa, João de Freitas Branco, Gerhard Doderer, Constança Capdeville e João Ranita Nazaré consta das entradas que lhes é dedicada em: Castelo-Branco, Salwa (ed.) (2010) Enciclopédia da Música em Portugal no Século xx. Lisboa: Círculo de Leitores/Temas de Debates.

133 Por moderna Etnomusicologia refiro-me ao desenvolvimento da disciplina a partir das décadas de 70 e 80 que se caracterizou pelo alargamento do seu objecto de estudo ao contexto urbano (Reyes-Schramm 1979), ao estudo dos média (Malm \& Wallis 1984) e das músicas populares (Manuel 2001) e à adopção generalizada de uma perspectiva antropológica, tendo o trabalho etnográfico como abordagem principal (Feld \& Fox 1994).

134 CF. Castelo-Branco (2010b) para uma análise do campo de saberes que se construiu em Portugal, desde meados do século xix até à década de 80 do século xx, em torno da recolha e do estudo da música em contextos rurais. 
acumulando funções docentes no Instituto Gregoriano que havia me dirigido um convite para leccionar Etnomusicologia e História da Música, iniciando o meu percurso académico mo país.

O interesse da professora Maria Augusta Barbosa pela revisão da oferta do DCM em Etnomusicologia era total. Com seu apoio e a aprovação do Conselho Científico da FCSH, a Etnomusicologia passou a integrar o programa de Licenciatura com duas cadeiras anuais obrigatórias. A primeira apresentava uma introdução ao percurso histórico e às tendências actuais da disciplina; a segunda centrava-se na teoria e método e na elaboração e execução de um projecto de trabalho de campo supervisionado pela docente. Esta oferta era inovadora quer nos EUA quer noutros países da Europa onde, regra geral, a Etnomusicologia era apenas oferecida aos níveis de Mestrado e Doutoramento. No meu próprio percurso académico, os conteúdos das duas cadeiras obrigatórias na LCM constavam do programa do primeiro ano do Mestrado quer na Columbia University onde completei o Doutoramento em Etnomusicologia em 1980, quer na New York University onde leccionei no programa de Mestrado em Etnomusicologia Urbana, entre 1979 e 1982. Nessa altura e mesmo na actualidade, na maioria das instituições, no âmbito da Licenciatura, a Etnomusicologia é introduzida através de uma cadeira de "Culturas Musicais do Mundo" centrada na audição e na análise de trechos musicais exemplificativos das características de algumas culturas musicais extra-europeias. ${ }^{135}$

Com efeito, a introdução tardia da Etnomusicologia em Portugal, a abertura e o apoio da professora Maria Augusta Barbosa, assim como a qualidade dos alunos das primeiras fornadas propiciaram o lançamento de um programa de ensino avançado a nível de Licenciatura. Esta oferta veio a dar frutos numa geração que, estimulada pela experiência de trabalho de campo na fase inicial da sua formação, escolheu a Etnomusicologia como área de especialização, continuando os seus estudos a nível de pós-graduação, ou aplicou

135 Desde a década de 80 que tem havido uma grande expansão em Universidades Europeias e Norte Americanas na oferta de uma cadeira de Licenciatura com as características acima descritas. Esta expansão é atestada pela proliferação de livros destinados ao apoio pedagógico de tais cadeiras, alguns já com várias edições, por exemplo: Titon (2009), Miller (2009), Nettl (2012), Wade (2009). Através destas cadeiras e dos livros que a elas se destinam, constituiu-se um canon de culturas musicais de conhecimento "obrigatório", entre as quais se destacam: África sub-sahariana, a Ilha de Java na Indonésia, sobretudo a prática e teoria associadas ao gamelão, e a tradição Hindustânica erudita do Norte da Índia. 
a abordagem etnomusicológica ao estudo da música erudita, ou a outras actividades profissionais.

Em sintonia com a professora Maria Augusta Barbosa, tracei como objectivos para o meu trabalho académico no DCM: "ministrar ensino actualizado em termos teóricos e metodológicos de modo a formar uma nova geração de etnomusicólogos competentes e internacionalmente competitivos; incentivar os jovens formandos a levar a cabo investigação etnomusicológica em Portugal e no espaço lusófono em torno de problemáticas actuais; encetar um dialogo científico com uma rede alargada de instituições e investigadores em Portugal e no estrangeiro de modo a colocar Portugal no circuito internacional de produção científica no domínio da Etnomusicologia” (Castelo-Branco 2010b).

As primeiras fornadas de alunos que tiraram as cadeiras de "Etnomusicologia I e II" acabaram com excelentes resultados. Vários apresentaram trabalhos que tinham desenvolvido no âmbito das duas disciplinas nos Encontros de Musicologia, organizados em colaboração com a Associação Portuguesa de Educação Musical (APEM), que vieram a ser publicados posteriormente no Boletim da mesma associação. O conjunto dos trabalhos foca problemáticas centrais na moderna Etnomusicologia: o papel social de um coro amador (Cardoso 1986), o Hot-Clube de Portugal enquanto instituição sócio-musical (Aresta e Gomes 1986), os espaços de performação do rock em Lisboa (Giga e Gaio 1986), a música na publicidade (Cymbron e Cruz 1986), a mudança musical num contexto rural (Carvalho e Oliveira 1987), as práticas musicais da comunidade judaica lisboeta (Borges e Miranda 1987), as transformações no repertório rural efectuadas por um grupo urbano de recriação (Correia e Neves 1987) e o papel do grupo folclórico federado (Sardo 1988). Três Licenciados das primeiras fornadas completaram os seus doutoramentos em Etnomusicologia. Actualmente colegas meus, ocupam cargos de docentes e investigadores no Ensino Superior em Portugal: João Soeiro de Carvalho e Maria de São José Côrte-Real na FCSH da UNL, e Susana Sardo na Universidade de Aveiro. Das gerações seguintes de Licenciados do DCM, vários prosseguiram com Doutoramentos em Etnomusicologia, sendo hoje profissionais de reconhecido mérito: Jorge Castro Ribeiro e Maria do Rosário Pestana são docentes na Universidade de Aveiro; Rui Cidra, António Tilly, Pedro Félix, Pedro Roxo e Leonor Losa são investigadores no Instituto de Etnomusicologia - Centro de 
Estudos em Música e Dança (INET-MD), unidade de investigação sediada na FCSH, tendo colaborado em vários projectos de investigação do INET-MD e na coordenação da Enciclopédia da Música em Portugal no Século xx, editada em quatro volumes, em 2010. ${ }^{136}$

\section{Considerações Finais}

Ao longo das últimas três décadas, o DCM consolidou a LCM, lançou cursos de Mestrado e Doutoramento em Ciências Musicais (com áreas de especialização em Musicologia Histórica, Etnomusicologia e Psicologia da Música), Artes Musicais, e Ensino da Música, institucionalizou e incrementou a investigação levada a cabo pelos seus docentes e discentes, e por outros investigadores portugueses e estrangeiros através de dois centros de investigação sediados na FCSH, o INET-MD - Instituto de Etnomusicologia - Centro de Estudos em Música e Dança, fundado por Salwa Castelo-Branco, em 1995, e o CESEM Centro de Estudos de Sociologia e Estética da Música, fundado por Mário Vieira de Carvalho, em 1997. Com efeito, trinta anos volvidos ao lançamento pela Professora Maria Augusta Barbosa da LCM, pioneira na Península Ibérica e no mundo lusófono, está patente o impacte do DCM no Ensino Superior da música e da musicologia, assim como no meio cultural Português em geral. Conforme demonstra João Soeiro de Carvalho num trabalho recente, o DCM graduou 407 Licenciados, 69 Mestres em Ciências Musicais, 25 Mestres em Artes Musicais, 64 Mestres em Formação de docentes e 17 Doutores em Ciências Musicais. Muitos dos diplomados do DCM desempenham cargos de relevância no Ensino Superior e em instituições culturais aos níveis nacional e regional. O DCM é hoje também reconhecido a nível internacional como uma instituição de excelência através do trabalho científico dos seus docentes e de alguns dos seus graduados, e da produção científica dos seus dois Centros de Investigação.

\footnotetext{
136 Pedro Félix e Rui Cidra são Licenciados em Antropologia, tendo tirado as cadeiras de Etnomusicologia por mim leccionadas no DCM. Rui Cidra defendeu o Doutoramento em Dezembro do ano passado. À excepção de Leonor Losa, mestre e doutoranda em Etnomusicologia, a defesa dos doutoramentos dos restantes investigadores acima referidos está programada para a primavera do corrente ano.
} 
Neste momento de grande transformação na sociedade portuguesa, na Europa e no mundo, importa fixar a memória do passado, elaborando uma história "multi-vocal" da institucionalização das Ciências Musicais no país, a partir do levantamento e análise da documentação disponível, assim como dos testemunhos de todos que nela colaboraram. ${ }^{137}$ Ao mesmo tempo, urge construirmos o futuro, respondendo às necessidades e aos desafios da sociedade actual e incrementando qualitativa e quantitativamente a nossa produção científica, norteados pelo mesmo espírito crítico e exigente que caracterizou a professora Maria Augusta Barbosa, prestando-lhe desse modo a nossa homenagem.

\section{Bibliografia Citada}

Aresta, Paula; Gomes, Bernardo de Azevedo (1986) "O Hot-Club de Portugal: uma instituição sócio-musical lisboeta”, in III Encontro Nacional de Musicologia. Actas, Boletim da Associação Portuguesa de Educação Musical 48: 51-52.

Bohlman, Philip (2008) "Returning to the Ethnomusicological Past," in Gregory Barz and James Cooley, Shadows in the Field: New Perspectives for Fieldwork in Ethnomusicology. 2 ed. Nova Iorque: Oxford University Press.

Borges, Maria José; Miranda, Zélia Maria (1987) "O culto religioso judaico: alguns aspectos da actual prática musical na comunidade lisboeta”, in IV Encontro Nacional de Musicologia. Actas, Boletim da Associação Portuguesa de Educação Musical 52: 26-28.

Cardoso, José Maria Pedrosa (1986) "Papel social de um coro amador na área de Lisboa", in III Encontro Nacional de Musicologia. Actas, Boletim da Associação Portuguesa de Educação Musical, 48: 47-50.

Carvalho, João Soeiro de; Oliveira, M. de S. José (1987) "Monsanto, uma tradição musical em mudança", in IV Encontro Nacional de Musicologia. Actas, Boletim da Associação Portuguesa de Educação Musical 52: 20-25.

Carvalho, João Soeiro (2012) "Três décadas de Ciências Musicais na Universidade Nova de Lisboa: balanço e novos desafios”. Trabalho inédito.

Castelo-Branco, Salwa (ed.) (2010) Enciclopédia da Música em Portugal no Século xx. Lisboa: Círculo de Leitores/Temas e Debates.

Castelo-Branco, Salwa (2010a) "Universidade Nova de Lisboa", in Enciclopédia da Música em Portugal no Século $x$, vol. IV. Lisboa: Círculo de Leitores/Temas e Debates.

\footnotetext{
137 Para um breve percurso histórico do DCM, cf. Castelo-Branco 2010a.
} 
Castelo-Branco, Salwa (2010b) "Etnomusicologia," in Enciclopédia da Música em Portugal no Século x, vol. II. Lisboa: Círculo de Leitores/Temas e Debates.

Clifford, James (1986) "Introduction: Partial Truths," in James Clifford \& Jorge Marcus (1986) Writing Culture: The Poetics and Politics of Ethnographic Writing. Berkley e Los Angeles: The Univeristy of California Press.

Clifford, James \& Marcus, Jorge (1986) Writing Culture: The Poetics and Politics of Ethnographic Writing. Berkeley e Los Angeles: The Univeristy of California Press.

Correia, Maria Clara; Neves, Rosa Clara (1987) "Sementes e a etnomusicologia em Portugal", in IV Encontro Nacional de Musicologia. Actas, Boletim da Associação Portuguesa de Educação Musical 52: 29.

Cymbron, Luísa; Cruz, Nuno Ivo (1986) "A importância da música na publicidade em Portugal", in III Encontro Nacional de Musicologia. Actas, Boletim da Associação Portuguesa de Educação Musical, 48: 55-57.

Feld, Steven \& Fox, Aaron (1994) "Music and Language", Annual Review of Anthropology 23: 25-53.

Giga, Idalete; Gaio, Ana Isabel (1986) "O fenómeno rock em Lisboa", in III Encontro Nacional de Musicologia. Actas, Boletim da Associação Portuguesa de Educação Musical, 48: 53-54.

Malm, Krister \& Wallis, Roger (1984) Big Sounds from Small Peoples. Londres: Constable.

Manuel, Peter (2001) "World Popular Music," 2a pt. in Stanley Sadie (ed.) The New Grove Dictionary of Music and Musicians. Londres: Macmillan.

Miller, Terry (2009) World Music: A Global Journey. 2 ed. Nova Iorque: Taylor and Francis.

Mugglestone, Erica (1981) "'Guido Adler's The Scope, Method and Aim of Musicology': A Translation with a Historico-Analtical Commentary," Yearbook for Traditional Music 13: 1-21.

Nettl, Bruno et. al. (2012). Excursions in World Music. 6 ed. Nova Iorque: Pearson.

Reyes, Schramm, Adelaide (1979) "Ethnic Music, the Urban Area and Ethnomusicology," Sociologus 1 - 19.

Shelemay, Kay (1980) "Historical Ethnomusicology: Reconstructing Falasha Liturgical History,” Ethnomusicology 24: 233-258.

Titon, Jeff (ed.) (2009) World of Music: An Introduction to the Music of the World People's. 3 ed. Nova Iorque: Schrimer.

Wade, Bonnie (2009) Thinking Musically: Experiencing Music, Expressing Culture. 2 ed. Nova Iorque: Oxford University Press. 
(Página deixada propositadamente em branco) 
Série Documentos

Imprensa da Universidade de Coimbra

Coimbra University Press

2012

Obra Publicada

com a coordenação

Científica

P

$\mathrm{ECH}$

FCT

Fundação para a Ciência e a Tecnologia MINISTÉRIO DA HDUCAÇ̄̇o в CIẼNCA

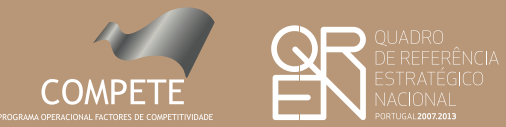

